NBER WORKING PAPER SERIES

\title{
ROOTS OF AUTOCRACY
}

\author{
Oded Galor \\ Marc Klemp \\ Working Paper 23301 \\ http://www.nber.org/papers/w23301
}

\author{
NATIONAL BUREAU OF ECONOMIC RESEARCH \\ 1050 Massachusetts Avenue \\ Cambridge, MA 02138 \\ March 2017
}

The authors are grateful for valuable comments from Alberto Alesina, James Fenske, Martin Fiszbein, Elhanan Helpman, Stelios Michalopoulos, Nathan Nunn, Nico Voigtlaender, participants in the conferences CEPR Growth Conference 2016, London, Deep Determinants of International Comparative Development, Brown University, Towards Sustained Economic Growth, Barcelona, MEHR, Copenhagen, NBER Political Economy 2016, Association for the Study of Religion, Economics, and Culture 2016, ASSA 2017, as well as seminar participants at Copenhagen, Harvard, Kiel, Louvain, Oxford, Tel Aviv, and Warwick. The research of Galor is supported by NSF grant SES-1338426. The research of Klemp has been funded partially by the Carlsberg Foundation and the Danish Research Council reference no. 1329-00093 and reference no. 1327-00245. The views expressed herein are those of the authors and do not necessarily reflect the views of the National Bureau of Economic Research.

NBER working papers are circulated for discussion and comment purposes. They have not been peer-reviewed or been subject to the review by the NBER Board of Directors that accompanies official NBER publications.

(C) 2017 by Oded Galor and Marc Klemp. All rights reserved. Short sections of text, not to exceed two paragraphs, may be quoted without explicit permission provided that full credit, including () notice, is given to the source. 
Roots of Autocracy

Oded Galor and Marc Klemp

NBER Working Paper No. 23301

March 2017

JEL No. O10,O43,Z1

\section{ABSTRACT}

Exploiting a novel geo-referenced data set of population diversity across ethnic groups, this research advances the hypothesis and empirically establishes that variation in population diversity across human societies, as determined in the course of the exodus of human from Africa tens of thousands of years ago, contributed to the differential formation of pre-colonial autocratic institutions within ethnic groups and the emergence of autocratic institutions across countries. Diversity has amplified the importance of institutions in mitigating the adverse effects of noncohesiveness on productivity, while contributing to the scope for domination, leading to the formation of institutions of the autocratic type.

Oded Galor

Department of Economics

Brown University

Box B

Providence, RI 02912

and CEPR

and also NBER

oded_galor@brown.edu

Marc Klemp

Økonomisk Institut

University of Copenhagen

Øster Farimagsgade 5, bygning 26

1353 København K

and Brown University

marc.klemp@econ.ku.dk 


\section{Introduction}

Political institutions have been widely viewed as major determinants of economic growth and comparative economic development. The origins of the existing variation in the nature of political institutions across the globe has been attributed to a variety of proximate factors underlying the contribution of economic prosperity and the threat of revolution to the onset of democracy as well as the association between inequality, ethnic fractionalization, and class stratification with the formation of autocratic intuitions. ${ }^{1}$ Recently, attention has been drawn towards more fundamental factors that have been argued to affect the nature of the prevailing political institutions across former colonies, highlighting institutional legacy as well as economic incentives that lead to the implementation of differential political institutions by the various colonial powers in different geographical environments. ${ }^{2}$

This research explores the origins of variation in the nature and the persistence of pre-colonial political institutions, highlighting one of the deepest roots of autocracy molded during the dawn of the dispersion of anatomically modern humans across the globe. ${ }^{3}$ The study advances the hypothesis and establishes empirically that variation in the population diversity across human societies, as determined in the course of the exodus of Homo sapiens out of Africa tens of thousands of years ago, shaped the characteristics of political institutions in early stages of development and has persistently affected the attributes of contemporary institutions across societies.

The hypothesized contribution of population diversity to the emergence of autocratic institutions rests on two fundamental building blocks. First, in view of the adverse effect of population diversity on social cohesiveness and aggregate productivity, the emergence of formal or informal institutions, and their associated code of conduct, would have plausibly mitigated the detrimental effects of population heterogeneity on the efficiency of the productive process. The scope for the emergence of institutions has therefore been larger in more diverse societies. Second, population diversity, and its manifestation in heterogeneity in cognitive as well as physical traits, has conceivably fostered the degree of inequality and class stratification in society, amplifying the scope for domination, and permitting elites to implement autocratic institutions. Thus, the dual effect of population diversity on the demand for institutions and on class stratification has contributed to the emergence of autocratic institutions. ${ }^{4}$

\footnotetext{
${ }^{1}$ See Lipset (1960), Acemoglu and Robinson (2012), Aghion et al. (2004), and Alesina and Giuliano (2015).

${ }^{2}$ See Engerman and Sokoloff (1997), La Porta et al. (1999), and Acemoglu et al. (2001).

${ }^{3}$ Furthermore, pre-colonial state formation has been attributed to the establishment of sedentary communities and the subsequent rise in social complexity in the post-Neolithic Revolution era (Mann, 1986; Belfer-Cohen and BarYosef, 2002). State formation has been associated with the rise in population density in the post-Neolithic period (Diamond, 1997), the rise in food surplus necessary for the creation of a non-food producing class due to climatic shocks, technological advancements, and the gains from trade (Gosden, 1989; Allen, 1997; Arnold, 1993; Fenske, 2014; Litina, 2014), and the existence of storable crops that permitted extraction by the ruling elite Mayshar et al. (2015).

${ }^{4}$ The hypothesis that genetic diversity is associated with the scope for domination is supported by evidence from stow of the closest species to human beings. The Chimpanzees whose level of genetic diversity of 0.82 , is larger than the one present in the human species (Pemberton et al., 2013) are characterized by extreme social stratification associated with a dominating alpha male. In contrast, the Bonobo, that diverged from the common chimpanzees due to their geographical isolation dictated by the Congo River, are characterized by greater genetic homogeneity and more egalitarian. This evidence suggests that the hypothesis advanced in this paper may be relevant for the
} 
The conjectured effect of population diversity on the degree of autocratic institutions and the proposed mechanism that governs this effect are examined empirically across ethnic groups during the pre-colonial era as well as across nations during the contemporary period. The ethnic level empirical analysis is conducted on a novel geo-referenced dataset consisting of ethnic groups, for which population diversity is either observed, or can be predicted, and geographic, ethnographic and institutional characteristics are mostly available, whereas the country-level empirical analysis exploits existing data on population diversity as constructed by Ashraf and Galor (2013).

The empirical analysis is conducted in several layers as outlined in Figure 1. The first layer of the empirical analysis explores the impact of population diversity on the degree of autocratic institutions across ethnic groups, as well as the hypothesized mechanism that governs this reducedform relationship. In particular, consistent with the conjecture that ethnic groups characterized by higher population diversity are more likely to form institutions that would mitigate the adverse effect of the inherent non-cohesiveness associated with diversity, the empirical analysis establishes that, among the ethnic groups for which data on observed population diversity and institutions are available, ethnic groups that are characterized by a higher level of population diversity tend to possess more elaborate institutions, as captured by the degree of jurisdictional hierarchy in those societies, accounting for potentially confounding geographical characteristics as well as regional fixed effects.

In light of potential concerns about the endogeneity of observed population diversity and the size and the representativeness of the ethnic group sample with observed population diversity, the research exploits two empirical strategies to identify the causal effect of population diversity on autocracy and to demonstrate the robustness of the estimated effect. First, in view of the negative effect of migratory distance from the cradle of humankind in East Africa to various settlements across the globe on population diversity, migratory distance from Africa is exploited as an instrumental variable for observed population diversity, establishing a highly significant causal effect of diversity on the degree of jurisdictional hierarchy. Second, using migratory distance from Africa to predict population diversity for 1,267 ethnic groups in the Ethnographic Atlas, the analysis further establishes the robustness of the result for this extended sample.

Further, consistent with the second element of the proposed mechanism about the impact of population diversity on social stratification, the empirical analysis establishes that, among the ethnic groups for which data on observed population diversity and social stratification are available, ethnic groups that are characterized by a higher level of population diversity tend to have a higher level of class stratification. In addition, among the ethnic groups for which data on observed population diversity and the presence of slavery are available, ethnic groups that are characterized by a higher level of population diversity tend to be have a higher intensity of slavery. Moreover, exploiting migratory distance from Africa as: (i) an instrumental variable for observed population diversity, and (ii) to predict population diversity for all ethnic groups in the Ethnographic Atlas, the

undersetting of the emergence of domination across variety of groups distinguished regardless of their scale or their cognitive functioning. 
empirical analysis establishes a highly significant causal and robust effect of population diversity on class stratification and the intensity of slavery, accounting for potentially confounding geographical characteristics as well as regional fixed effects.

Moreover, the ethnic-level empirical analysis explores the contribution of the dual effect of population diversity, on the emergence of intuitions as well as on the degree of social stratification, to the emergence of autocratic institutions. In line with the proposed mechanism, the empirical analysis establishes that the number of levels of jurisdictional hierarchy and the degree of social stratification are associated with the presence of autocratic institutions, captured by various measures reported by the Standard Cross Cultural Survey (SCCS) such as: (i) degree of absence of checks on leader's power, (ii) difficulty of removal of leaders, (iii) leader's exercise of authority, (iv) degree of lack of community decisions, and (v) perception of leader's power. Hence, these findings indicate that the impact of diversity on the prevalence of autocratic institutions could have plausibly operated through its dual effect on the formation of institutions as well as class stratification. Finally, the ethnic-level analysis suggests that there exists a positive reduced-form effect of predicted population diversity on the various measures of autocracy reported by the SCCS.

Thus, consistent with the proposed hypothesis, the first layer of empirical analysis suggests that population diversity contributed to the degree of pre-colonial autocratic institutions across ethnic groups, while lending credence to the hypothesized mechanism that governs this reduced-form relationship, according to which population diversity contributed to the demand for institutions as well as for the scope for domination, giving rise to institutions of the autocratic type.

The second layer of the empirical analysis explores that importance of the impact of population diversity on pre-colonial autocratic institutions across ethnic groups for understanding the contemporary variation in autocratic institutions across nations. In particular, it examines the persistence of ethnic institutions that were formed in the pre-colonial era and their association with contemporary national institutions. Aggregating pre-colonial ethnic institutions into precolonial national institutions, the analysis suggests that indeed pre-colonial ethnic institutions have contributed to the contemporary institutions, beyond the persistent effect of geographical determinants. In particular, the degree of autocratic institutions and the absence of executive constraints in the contemporary period are positively and significantly associated with the degree of autocratic institutions in the pre-colonial era, accounting for potentially confounding effects of geographical characteristics and population diversity. Moreover, the findings suggest that the persistence of institutions can be partly attributed to the direct effect of population diversity on both pre-colonial and contemporary institutions.

The third layer of the empirical analysis examines the reduced-form relationship between population diversity and the nature of contemporary national institutions. Consistent with the proposed hypothesis, it establishes that population diversity at the national level, as captured by predicted population diversity has a significant direct effect on the degree of autocracy across countries and of the absence of executive constraints, accounting for a large number of confounding geographical characteristics, regional fixed effects, colonial history (i.e., duration and colonizer nation), legal ori- 


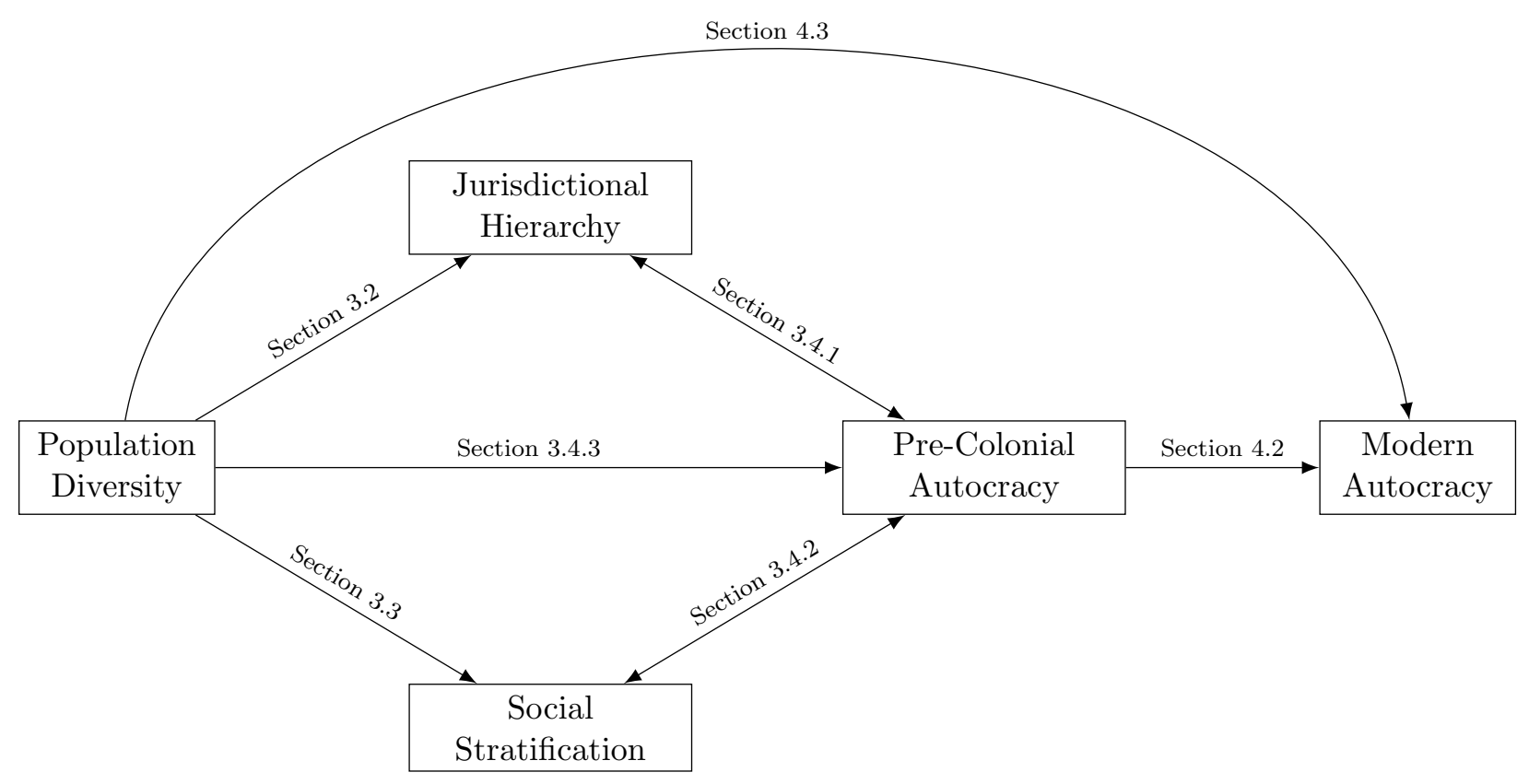

Figure 1: Overview of the empirical analysis with references to the relevant sections of the paper.

gins, pre-colonial development and ethnolinguistic fractionalization (and its geographical origins). Moreover, the effect remains nearly intact if one accounts for arguably endogenous controls such as income per capita and education.

Thus, the third layer of the empirical analysis suggests that the spatial distribution of population diversity across the globe has also contributed to contemporary variation in the degree of autocracy across countries. This reduced-form effect of population diversity on the prevalence of contemporary autocratic institutions across nations may reflect either persistence of institutions from the precolonial to the modern era, as established in the second layer of the analysis, or a direct effect of population diversity on contemporary autocratic institutions, capturing the effect of diversity on the demand for institutions as well as for the scope for domination.

\section{Empirical Framework}

\subsection{Empirical Strategy}

This research advances the hypothesis that diversity contributed to the concentration of power over the course of human history within social groups, such as ethnic groups or nation states. Furthermore, it suggests that this effect was governed by the impact of population diversity on the emergence of institutions as well as on the degree of social stratification. 
The proposed hypothesis is examined empirically across ethnic groups during the pre-colonial era as well as across nations during the contemporary period. This empirical setup is desirable for several reasons. First, the inclusion of the pre-colonial as well as the modern era is designed to capture the effect of institutions over the course of human history. Second, the analysis of the pre-colonial era as well as the modern one permits the analyses to capture the effect of population diversity across groups of various dimensions (i.e., ethnic groups as well as nations). Third, in view of the important effect of colonialism on institutions, the pre-colonial analysis is immune from the potential confounding effect of colonialization. Fourth, this intertemporal setup permits the examination of the persistence effect of pre-colonial institutions on the contemporary ones and it allows the isolation of the direct effect of population diversity on contemporary institutions from its lingering effect via the persistence of past institutions. Fifth, the focus on ethnic groups permits that analysis to disentangle the effect of phenotypic diversity (within an ethnic group) from ethnic diversity (across groups).

\subsection{Measure of Population Diversity}

This research highlights the pivotal contribution of population diversity for the emergence of autocratic institutions. While population diversity can be captured by ethnolinguistic fractionalization, ethnolinguistic polarization, or genetic diversity, several reasons suggests that genetic diversity ought to be used in order to properly capture the hypothesized effects of population diversity.

First, while population diversity at the national level can be captured by each of the three measures, diversity within ethnic groups can be captured only by existing measures of genetic diversity. Second, for the country level analysis, measures of ethnolinguistic fractionalization captures primarily the proportional representation of each ethnic group in the population, while measures of ethnic polarization incorporate proxies for pairwise dissimilarities amongst ethnic groups within the population. In contrast, the genetic diversity of a national population is an index that incorporates information on all three dimensions of heterogeneity at the country level: the proportional representation of each ethnic group, the pairwise dissimilarities across these groups (as captured by genetic distance), and most importantly, the degree of interpersonal diversity within each group (as captured by genetic diversity within the group). Third, since the hypothesized effect population diversity on inequality and social stratification is operating via heterogeneity in cognitive as well as physical traits, the measure of population diversity ought to reflect phenotypic diversity. A-priori the degree of either fractionalization or polarization does not necessarily reflect the degree of phenotypic diversity, whereas genetic diversity is correlated with phenotypic diversity.

Thus the study employs various measures of genetic diversity (i.e., observed genetic diversity within ethnic groups, predicted genetic diversity within ethnic groups, predicted genetic diversity within countries, and ancestry adjusted predicted genetic diversity within countries) to capture population diversity. 


\subsubsection{Observed Population Diversity within Ethnic Groups}

Population geneticists use an index known as expected heterozygosity to measure the extent of diversity in genetic material across individuals in a given population (e.g., an ethnic group). Genetic diversity captures the probability that two individuals, selected at random from a given population, differ from one another with respect to a spectrum of genetic traits. In particular, the overall expected heterozygosity for a given population is the average gene-specific heterozygosity (based on the proportional representations of different alleles of this trait in the population) over multiple DNA loci.

Existing measures of expected heterozygosity for indigenous ethnic groups are created by population geneticists utilizing data on allelic frequencies within a particular class of DNA loci labelled microsatellites, located in non-protein-coding regions of the human genome and are largely regarded as selectively neutral. This attribute has a major advantage, assuring that this measure of genetic diversity is unaffected by factors that are correlated with political institutions that could have governed the process of natural selection. Nevertheless, a conceptually meaningful measure of genetic diversity (i.e., a measure that can capture the effect of political and economic outcomes) ought to reflect diversity in phenotypically expressed traits. Reassuringly, diversity in microsatellites is positively correlated with heterogeneity in phenotypically expressed genomic material. In particular, similarly to expected heterozygosity in neutral genetic markers, evidence suggests that a serial founder effect associated with migratory distance from East Africa has a negative effect on various forms of morphological and cognitive diversity (Henn et al., 2012), including diversity in skeletal features pertaining to cranial characteristics (Manica et al., 2007; von Cramon-Taubadel and Lycett, 2008; Betti et al., 2013), dental characterisitics (Hanihara, 2008), and pelvic attributes (Betti et al., 2013), as well as phonemic diversity (Atkinson, 2011).

This research employs a newly assembled data (Pemberton et al., 2013) on observed genetic diversity in 232 predominantly indigenous ethnic groups across the globe that have been largely isolated from genetic flows from other ethnic groups. ${ }^{5}$ The distribution of these ethnic groups across the globe is depicted in Figure 2 and the summary statistics of this measure of genetic diversity as documented in Table B.1 establishes that observed genetic diversity ranges from 0.77 in Africa to 0.58 in South America. ${ }^{6}$ Moreover, the study creates a novel geo-referenced dataset consisting of

\footnotetext{
${ }^{5}$ This dataset combines eight human genetic diversity datasets based on the 645 loci that they share, including the HGDP-CEPH Human Genome Diversity Cell Line Panel used by Ashraf and Galor (2013).

${ }^{6}$ The analysis excludes observations that are not marked as clean by Pemberton et al. (2013). These omitted observations either reflect genetic diversity of a large geographical region (e.g., Patagonia), rather than an ethnic group, or ethnicities that were subjected to significant admixture. Furthermore, it excludes two ethnicities (the Surui and the Ache of South America) that are largely viewed as extreme outliers in terms of genetic diversity (e.g. Wang et al., 2007). The exclusion of these ethnicities is not particular to our study. In particular, Ramachandran et al. (2005) omits the Surui, being "an extreme outlier in a variety of previous analyses", and did not include the Ache either. Furthermore, these ethnicities have the lowest levels of genetic diversity in the clean sample and the largest residuals of an OLS regression of genetic diversity on migratory distance from Addis Ababa. Including these observations, nevertheless, does not affect the qualitative analysis.
} 


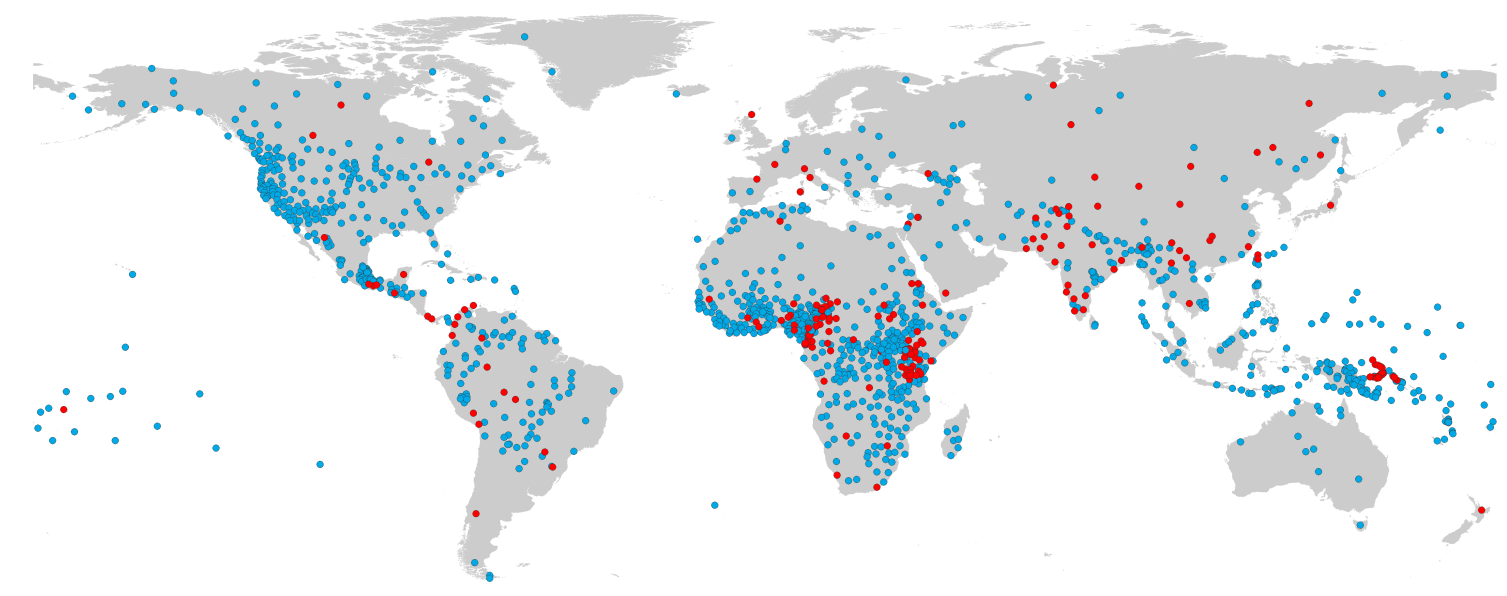

Figure 2: This figure depicts the interior centroids of the historical homelands of ethnic groups in the data. The red points mark observations with known observed and predicted genetic diversity and the blue points mark observations with known predicted genetic diversity.

ethnic groups, for which observed population diversity is matched to geographic, ethnographic and institutional characteristics. ${ }^{7}$

\subsubsection{Predicted Population Diversity within Ethnic Groups}

The research exploits the tight negative relationship between migratory distance from East Africa and observed genetic diversity across the ethnic group in the sample of Pemberton et al (2013) in order to generate a measure of predicted genetic diversity for all ethnic group in the Ethnographic Atlas, overcoming sample limitations as well as potential concerns about omitted variables and reverse causality that may affect the relationship between observed genetic diversity and political institutions. $^{8}$

The composition of genetic traits within populations has evolved in the course of a stepwise migration process of anatomically modern human out of Africa 90,000-60,000 BP. The "out of Africa" migration was associated with a decline in the degree of genetic diversity in populations that settled at greater migratory distances from Africa. In particular, following the serial founder effect, since the spatial diffusion of humans occurred in a sequence of steps, in which a subgroup of individuals left their parental colony to establish a new settlement farther away, carrying only a subset of the genetic diversity of their parental colony, the extent of genetic diversity observed within an indigenous ethnic group decreases with its migratory distance from East Africa (e.g.,

\footnotetext{
${ }^{7} \mathrm{~A}$ georeferenced mapping of the ethnographic characteristics of the ethnic groups to shed light on contemporary cultural traits was first introduced by Nunn (2008).

${ }^{8}$ Since predicted population diversity for each of the ethnic groups in the sample is a generated regressor, the analysis based on predicted population diversity employs a two-step bootstrapping algorithm to compute the standard errors (Table B.2 and B.3 in the Appendix).
} 


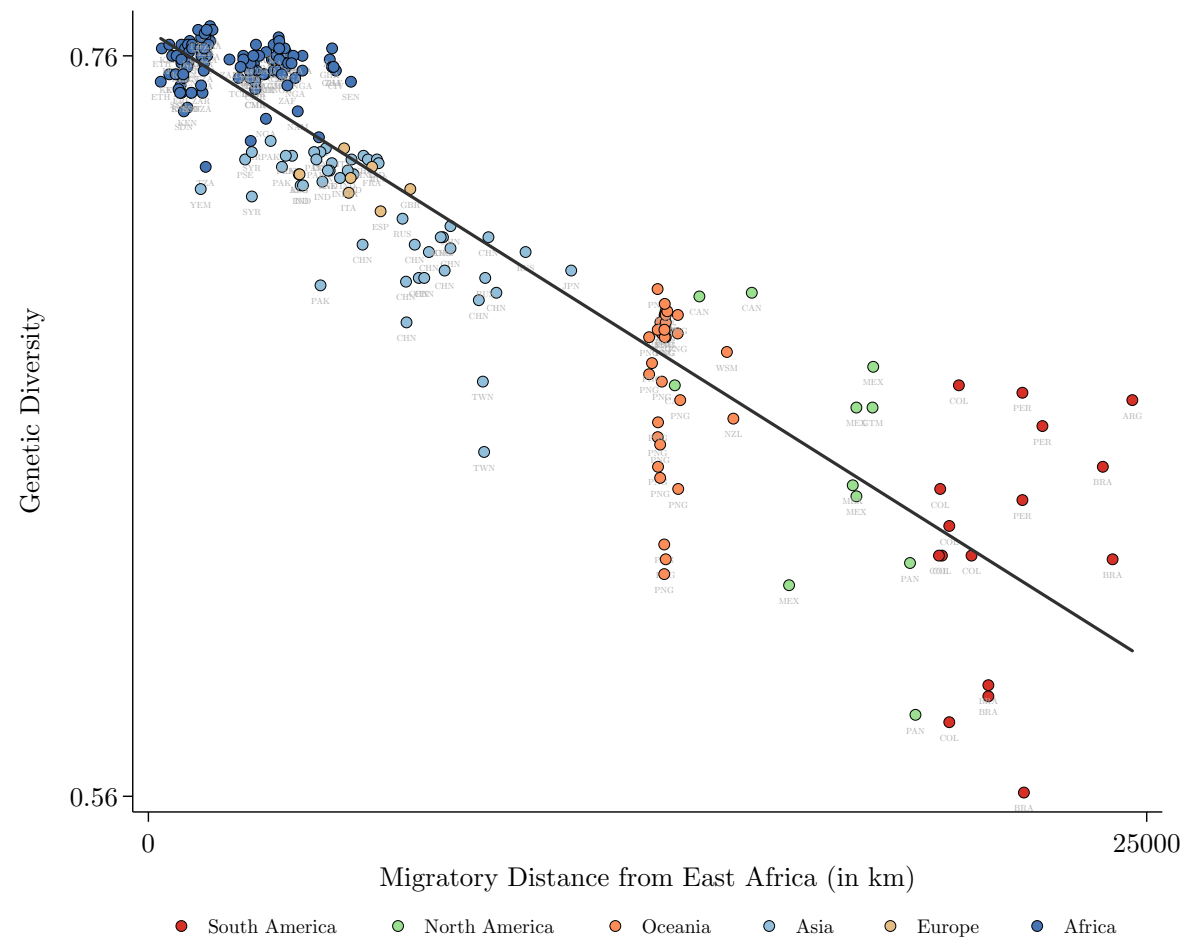

Figure 3: This figure depicts the negative impact of migratory distance from East Africa on genetic diversity across the 230 ethnic groups in the sample. The location of each ethnic group and its degree of genetic diversity is represented by a point and a World Bank code of the country in which the ethnic group resides.

Harpending and Rogers 2000; Ramachandran et al. 2005; Prugnolle, Manica, and Balloux 2005; Ashraf and Galor 2013b). ${ }^{9}$

Reflecting this chain of ancient population bottlenecks originating in East Africa, the scatter plot in Figure 3 depicts the highly significant negative effect of migratory distance from the cradle of mankind in East Africa on genetic diversity in the ethnic-group sample of Pemberton et al (2013). In particular, regressing genetic diversity on migratory distance from Addis Ababa in this sample suggest that expected heterozygosity falls by 6.7 percentage points for every $10,000 \mathrm{~km}$ increase in migratory distance from East Africa. Furthermore, migratory distance explains more than 84 percent of the cross-group variation in observed genetic diversity. ${ }^{10}$

\footnotetext{
${ }^{9}$ In the pre-colonial era, the geographical locations of societies reflected the locations to which their ancestral populations had arrived at the culmination of their prehistoric "out of Africa" migration from the cradle of humankind, and as such, the diversity of a precolonial society was presumably determined by the ancient serial founder effect originating in East Africa.

${ }^{10}$ As further elaborated in the Appendix, in estimating the migratory distance from Addis Ababa (East Africa) for each of the ethnic groups in the data, the shortest traversable paths from Addis Ababa to the interior centroid of each ethnic group was computed. Given the limited ability of humans to travel across large bodies of water, the traversable area included bodies of water at a distance of $100 \mathrm{~km}$ from land mass (excluding migration from Africa into Europe via Italy or Spain).
} 
The distribution of ethnic groups across the globe in this predicted diversity sample is depicted in Figure 2 and the summary statistics of this measure of genetic diversity as documented in Table B.1 establishes that observed genetic diversity ranges from 0.77 in Africa to 0.59 in South America.

\subsubsection{Predicted Population Diversity within Countries}

While the observed and predicted population diversity for ethnic groups is sufficient in order to conduct the ethnic-level analysis, the examination of the effect of population diversity on autocratic institutions across countries requires the use of a genetic diversity measure for national populations. However, national contemporary populations are composed of multiple ethnicities, which may not be indigenous to their current geographical locations. Thus, one needs to construct an index of genetic diversity for contemporary national populations that accounts for the proportional representation of each ethnic group within the country, the expected heterozygosity within each subnational group, as well as the diversity that arises from the genetic distances between the precolonial ancestral populations. Hence, the country-level analysis employs the measure of genetic diversity, as constructed by Ashraf and Galor (2013b), accounting for these three important elements of population diversity with a national population. ${ }^{11}$ The summary statistics of this measure of genetic diversity is documented in Table B.1.

\subsection{Measures of Political Institutions, Autocracy, and Social Stratification}

In view of the hypothesis that diversity contributed to demand for institutions as well as to the emergence of pre-colonial autocratic institutions which persisted over time and affected the nature of contemporary institutions, measures of pre-colonial institutions and pre-colonial and modern autocracy will be used.

For the analysis of pre-colonial institutions, the study exploits the arguably largest and most comprehensive collection of ethnographic tabulations found in the Ethnographic Atlas, consisting of ethnographic data for 1,267 worldwide ethnic groups (Murdock, 1967). Pre-colonial ethic level institutions are captured by "Jurisdictional Hierarchy Beyond Local Community", as reported by the Ethnographic Atlas. This widely used measure of pre-colonial institution (or statehood) consists of five gradations: (i) no political authority beyond the local community, (ii) one level (e.g., petty chiefdoms), (iii) two levels (e.g., larger chiefdoms), (iv) three levels (e.g., states), and (v) four levels (e.g., large states).

The presence of autocratic institutions in the pre-colonial era is captured by various measures such as: (i) degree of absence of checks on leader's power, (ii) difficulty of removal of leaders, (iii) leader's exercise of authority, (iv) degree of lack of community decisions, and (v) perception of leader's power, as reported by the Standard Cross Cultural Survey (Murdock and White, 1969). Furthermore, the degree of contemporary autocratic institutions is captured by the indexes of

\footnotetext{
${ }^{11}$ Since predicted population diversity for each country is a generated regressor, the empirical analysis based on predicted population diversity employs a two-step bootstrapping algorithm to compute the standard errors (Table B.2 and B.3 in the Appendix).
} 
"Autocracy" and "Constraints on the Executive" as reported by the gold standard in comparative research in political institutions: The Polity IV Project dataset (Marshall et al., 2014).

In light of the hypothesis that diversity contributed to the degree of social stratification, contributing to the emergence of pre-colonial autocratic institutions, various measures of social stratification will be used. First, "Class Stratification" as reported by the Ethnographic Atlas. This measure of social stratification is aggregated into three gradations: (i) absence of stratification, (ii) the presence of wealth distinctions or elite, and (iii) the presence of complex social classes or hereditary aristocracy.

\section{Population Diversity and Autocracy in the Pre-Colonial Era}

This section explores the impact of population diversity on the degree of pre-colonial autocratic institutions across ethnic groups. Moreover, it examines the hypothesized mechanism that may govern this reduced-form relationship. In particular, it investigates: (i) the effect of population diversity on pre-colonial jurisdictional hierarchy, (ii) the effect of population diversity on pre-colonial social stratification and slavery, (iii) the associations between pre-colonial jurisdictional hierarchy, social stratification and slavery, on the one hand, and pre-colonial autocracy on the other hand, and (iv) the effect of population diversity on pre-colonial autocracy.

In view of the conjecture that ethnic groups characterized by higher population diversity are more likely to form institutions that would mitigate the adverse effect of non-cohesiveness on productivity, the empirical analysis first examines whether ethnic groups that are characterized by a higher level of observed population diversity tend to possess more elaborate institutions, as captured by the degree of jurisdictional hierarchy in those societies.

In light of potential concerns about the endogeneity of observed population diversity as well as the size and the representativeness of the ethnic group sample with observed population diversity, the research exploits two empirical strategies to identify the causal effect of population diversity on autocracy and to demonstrate the robustness of the estimated effect. First, migratory distance from Africa is exploited as an instrumental variable for observed population diversity, in order to examine the potential causal effect of diversity on the degree of jurisdictional hierarchy, accounting for the potentially confounding effects of geographical characteristics as well as regional fixed effects. Second, using migratory distance from Africa to predict population diversity for 1,267 ethnic groups in the Ethnographic Atlas, the analysis explores the robustness of the result for this extended sample.

Further, in light of the second element of the proposed mechanism about the impact of population diversity on social stratification, the empirical analysis explores whether ethnic groups that are characterized by a higher level of observed population diversity tend to have a higher level of class stratification and a higher intensity of slavery. Moreover, exploiting migratory distance from Africa as: (i) an instrumental variable for observed population diversity, and (ii) as a predictor of population diversity for all ethnic groups in the Ethnographic Atlas, the empirical analysis ex- 
plores the causal and robust effect of population diversity on class stratification and the intensity of slavery, accounting for the potentially confounding effects of geographical characteristics as well as regional fixed effects.

Finally, the ethnic-level empirical analysis explores the contribution of population diversity to the emergence of autocratic institutions. In light of the proposed mechanism, the empirical analysis explores the association between jurisdictional hierarchy and the presence of autocratic institutions as captured by: (i) degree of absence of checks on leader's power, (ii) difficulty of removal of leaders, (iii) leader's exercise of authority, (iv) degree of lack of community decisions, and (v) perception of leader's power, Furthermore, it examines the association between social stratification and the intensity of slavery and these measures of autocracy. Moreover, the empirical analysis explores the reduced-form effect of predicted population diversity on each of these measures of autocracy.

\subsection{Baseline Regression Specifications}

This section presents the baseline econometric models that will be used in the empirical analysis of the relationship between population diversity and autocracy in the pre-colonial era.

\subsubsection{Population Diversity and Ethnographic Characteristics}

In estimating the association between observed population diversity and pre-colonial (i) jurisdictional hierarchy, (ii) stratification, and (iii) intensity of slavery, the following empirical specification is adopted and estimated via ordinary least squares (OLS): ${ }^{12}$

$$
Y_{i}=\beta_{0}+\beta_{1} G_{i}+X_{i}^{\prime} \beta_{2}+C_{i}^{\prime} \beta_{3}+\varepsilon_{i}
$$

where $Y_{i}$ is a measure of either jurisdictional hierarchy, social stratification, or intensity of slavery, for ethnicity $i ; G_{i}$ is observed population diversity for ethnicity $i, X_{i}$ is a vector of potentially confounding geographical control variables for ethnicity $i$; $C_{i}$ is a vector of continental dummies for ethnicity $i$; and $\varepsilon_{i}$ is an error term clustered at the country level for ethnicity $i$.

Moreover, considering the remarkably strong predictive power of migratory distance from East Africa for genetic diversity, the baseline regression specification employed to test the effect of predicted population diversity on pre-colonial (i) jurisdictional hierarchy, (ii) stratification, and (iii) intensity of slavery (in the extended sample of the entire set of ethnic groups in the Ethnographic Atlas) is estimated via OLS based on the following empirical specification: ${ }^{13}$

$$
Y_{i}=\beta_{0}+\beta_{1} \hat{G}_{i}+X_{i}^{\prime} \beta_{2}+C_{i}^{\prime} \beta_{3}+\varepsilon_{i}
$$

\footnotetext{
${ }^{12}$ As established in Table B.4 in the Appendix, the results are robust to the use of an alternative estimation method (i.e., ordered probit).

${ }^{13}$ As established in Table B.5 in the Appendix, the results are robust to the use of an alternative estimation method (i.e., ordered probit).
} 
where $\hat{G}_{i}$ is the level of population diversity predicted by migratory distance from East Africa for ethnicity $i$.

Furthermore, the causal effect of population diversity on pre-colonial jurisdictional hierarchy, stratification, and inequality is estimated via a 2SLS procedure, instrumenting observed population diversity with the migratory distance from East Africa in the sample of observed genetic diversity. In particular, the second stage of the 2SLS regression is given by equation (1), while the first stage of the 2SLS regression is estimated by the equation

$$
G_{i}=\alpha_{0}+a_{1} Z_{i}+X_{i}^{\prime} \alpha_{2}+C_{i}^{\prime} \alpha_{3}+\varepsilon_{i}
$$

where $Z_{i}$ is the migratory distance from East Africa to the centroid of the homeland of ethnicity $i$.

\subsubsection{Ethnographic Characteristics and Pre-Colonial Autocracy}

In estimating the association between pre-colonial autocracy and pre-colonial (i) jurisdictional hierarchy, (ii) stratification, and (iii) intensity of slavery, the following empirical specification is adopted and estimated via (OLS): ${ }^{14}$

$$
A_{i}=\beta_{0}+\beta_{1} Y_{i}+X_{i}^{\prime} \beta_{2}+C_{i}^{\prime} \beta_{3}+\varepsilon_{i}
$$

where $A_{i}$ is a measure of pre-colonial autocracy for ethnicity $i ; Y_{i}$ is a measure of either jurisdictional hierarchy, social stratification, or intensity of slavery, for ethnicity $i$.

\subsubsection{Population Diversity and Pre-Colonial Autocracy}

In estimating the association between predicted population diversity and pre-colonial autocracy, the following empirical specification is adopted and estimated via ordinary least squares (OLS): ${ }^{15}$

$$
A_{i}=\beta_{0}+\beta_{1} \hat{G}_{i}+X_{i}^{\prime} \beta_{2}+C_{i}^{\prime} \beta_{3}+\varepsilon_{i}
$$

\subsection{Population Diversity and Jurisdictional Hierarchy}

This subsection establishes the effect of population diversity on pre-colonial jurisdictional hierarchy across ethnic groups.

\subsubsection{Observed Population Diversity and Jurisdictional Hierarchy}

The first layer of this empirical analysis establishes that ethnic groups that are characterized by a higher level of observed population diversity tend to possess more elaborate institutions, as captured by the degree of jurisdictional hierarchy in those societies.

\footnotetext{
${ }^{14}$ As established in Table B.6 in the Appendix, the results are robust to the use of an alternative estimation method (i.e., ordered probit).

${ }^{15}$ As established in Table B.7 in the Appendix, the results are robust to the use of an alternative estimation method (i.e., ordered probit).
} 
Table 1: Observed Population Diversity and Jurisdictional Hierarchy

\begin{tabular}{|c|c|c|c|c|c|c|}
\hline & \multicolumn{6}{|c|}{ Log Number of Levels of Jurisdictional Hierarchy } \\
\hline & (1) & $(2)$ & (3) & (4) & $(5)$ & (6) \\
\hline Genetic Diversity & $\begin{array}{c}2.685^{* * *} \\
(0.922)\end{array}$ & $\begin{array}{c}4.197^{* * *} \\
(0.875)\end{array}$ & $\begin{array}{c}4.350^{* * *} \\
(0.908)\end{array}$ & $\begin{array}{c}7.894^{* * *} \\
(2.330)\end{array}$ & $\begin{array}{c}9.503^{* * *} \\
(3.023)\end{array}$ & $\begin{array}{c}9.645^{* * *} \\
(2.828)\end{array}$ \\
\hline Log Absolute Latitude & & $\begin{array}{c}0.151^{* * *} \\
(0.030)\end{array}$ & $\begin{array}{c}0.153^{* * *} \\
(0.032)\end{array}$ & $\begin{array}{c}0.091^{* *} \\
(0.035)\end{array}$ & $\begin{array}{c}0.079^{*} \\
(0.042)\end{array}$ & $\begin{array}{l}0.096^{* *} \\
(0.043)\end{array}$ \\
\hline Elevation & & & & & $\begin{array}{c}-0.000 \\
(0.000)\end{array}$ & $\begin{array}{c}0.000 \\
(0.000)\end{array}$ \\
\hline Terrain Ruggedness & & & & & $\begin{array}{c}0.000 \\
(0.000)\end{array}$ & $\begin{array}{c}0.000 \\
(0.000)\end{array}$ \\
\hline River Length & & & & & $\begin{array}{c}0.001^{* * *} \\
(0.000)\end{array}$ & $\begin{array}{c}0.003^{* * *} \\
(0.001)\end{array}$ \\
\hline River Density & & & & & $\begin{array}{c}0.017 \\
(0.029)\end{array}$ & $\begin{array}{c}0.027 \\
(0.023)\end{array}$ \\
\hline Share Desert & & & & & $\begin{array}{c}-0.167 \\
(0.304)\end{array}$ & $\begin{array}{c}-0.504^{* *} \\
(0.253)\end{array}$ \\
\hline Average Temperature & & & & & & $\begin{array}{c}0.028^{* *} \\
(0.011)\end{array}$ \\
\hline Temperature Range & & & & & & $\begin{array}{c}0.016 \\
(0.024) \\
\end{array}$ \\
\hline Soil Quality (Climatic) & No & No & Yes & Yes & Yes & Yes \\
\hline Continental FE & No & No & No & Yes & Yes & Yes \\
\hline$N$ & 131 & 131 & 131 & 131 & 131 & 131 \\
\hline Adjusted $R^{2}$ & 0.038 & 0.143 & 0.171 & 0.288 & 0.275 & 0.317 \\
\hline
\end{tabular}

This table presents the results of a series of OLS regression analyses, on the ethnic-group level, of a measure of pre-colonial jurisdictional hierarchy (the natural logarithm of the number of levels of jurisdictional hierarchy) on observed genetic diversity, conditional on a range of control variables at the ethnic-group level. Specifications marked with "Continental FE" accounts for sub-Saharan Africa, Latin America, and continental fixed effects. Heteroscedasticity-consistent standard errors are reported in parentheses. *** Significant at the 1 percent level. ** Significant at the 5 percent level. * Significant at the 10 percent level.

Table 1 presents the results from OLS regression analyses of the log number of levels of jurisdictional hierarchy in the pre-colonial era on observed population diversity. Consistent with the prediction of the proposed hypothesis, column 1 establishes a highly statistically and economically significant correlation between the measure of jurisdictional hierarchy and observed genetic diversity, based on the 131 ethnic groups for which information on both population diversity and jurisdictional hierarchy is available. In particular, a 1 percentage point increase in observed population diversity is associated with a 2.7 percent increase in the number of levels of jurisdictional hierarchy. In light of the potentially confounding effects of geographical characteristics on this association, columns 2-4 establish that this association is robust to the gradual inclusion of control 
variables, capturing a range of geographical factors. In particular, the association remains highly significant while accounting for the absolute latitude of the centroid of the homeland of the ethnicity (column 2), soil quality decile fixed effects (column 3), ${ }^{16}$ and continental fixed effects which capture unobserved heterogeneity across continents (column 4). In addition, column 5 establishes that the association remain highly significant while accounting for the potentially confounding effects of elevation of the homelands, terrain ruggedness, length and density of rivers, and the share of desert. Similarly, column 6 establishes that the association remain highly significant once the average and range of temperatures is accounted for.

Thus, Table 1 establishes that the estimated association between observed genetic diversity and pre-colonial jurisdictional hierarchy is highly statistically and economically significant, accounting for a wide range of potentially confounding geographical characteristics and continental fixed effects. In particular, a 1 percentage point increase in observed population diversity is associated with a 9.6 percent increase in the number of levels of jurisdictional hierarchy. This partial association between jurisdictional hierarchy and population diversity, as derived in column 6, is plotted in Panel A of Figure A.1.

\subsubsection{Observed Diversity \& Jurisdictional Hierarchy: Instrumental Variable Analysis}

In light of potential concerns about the endogeneity of observed population diversity, the second layer of this empirical analysis exploits an instrumental variable strategy to identify the causal effect of population diversity on jurisdictional hierarchy. In view of the negative effect of migratory distance from the cradle of humankind in East Africa to various settlements across the globe on population diversity, migratory distance from Africa is exploited as an instrumental variable for observed population diversity, establishing a highly significant causal effect of diversity on the degree of jurisdictional hierarchy.

Table 2 presents the results from 2SLS regression analyses of the log number of levels of jurisdictional hierarchy in the pre-colonial era on observed population diversity. Interestingly, in comparison to their OLS counterparts in Table 1, the estimated 2SLS coefficients associated with the effect of diversity remain relatively stable in magnitude, suggesting that omitted variable bias or endogeneity of genetic diversity need not be a source of concern. In particular, column 1 establishes that migratory distance from East Africa is a very strong instrument for genetic diversity (the Kleibergen-Paap $F$-statistic is 237) and that there is a highly statistically and economically significant effect of observed genetic diversity on the log number of levels of jurisdictional hierarchy. In particular, a 1 percentage point increase in the level of observed genetic diversity increases the number of levels of jurisdictional hierarchy by 2.9 percent.

Furthermore, columns $2-5$ establish that this effect is robust to the gradual inclusion of control variables capturing a range of geographical factors. In particular, migratory distance from East Africa remains a strong instrument for population diversity, and the effect of population diversity

\footnotetext{
${ }^{16}$ Considering decile fixed effects better accounts for the potential non-linearity of soil-quality on the various outcomes, but the results are robust to the use of a linear continuous specification.
} 
Table 2: Observed Population Diversity and Jurisdictional Hierarchy — IV Analysis

\begin{tabular}{|c|c|c|c|c|c|}
\hline & \multicolumn{5}{|c|}{ Log Number of Levels of Jurisdictional Hierarchy } \\
\hline & $(1)$ & $(2)$ & $(3)$ & $(4)$ & $(5)$ \\
\hline Genetic Diversity & $\begin{array}{c}2.911^{* *} \\
(1.161)\end{array}$ & $\begin{array}{c}4.570^{* * *} \\
(1.233)\end{array}$ & $\begin{array}{c}4.750^{* * *} \\
(1.120)\end{array}$ & $\begin{array}{c}5.407^{* * *} \\
(1.504)\end{array}$ & $\begin{array}{r}5.203^{* * *} \\
(1.356)\end{array}$ \\
\hline Log Absolute Latitude & & $\begin{array}{c}0.156^{* * *} \\
(0.031)\end{array}$ & $\begin{array}{c}0.157^{* * *} \\
(0.031)\end{array}$ & $\begin{array}{c}0.144^{* * *} \\
(0.035)\end{array}$ & $\begin{array}{c}0.193^{* * *} \\
(0.041)\end{array}$ \\
\hline Elevation & & & & $\begin{array}{c}0.000 \\
(0.000)\end{array}$ & $\begin{array}{c}0.000 \\
(0.000)\end{array}$ \\
\hline Terrain Ruggedness & & & & $\begin{array}{c}0.000 \\
(0.000)\end{array}$ & $\begin{array}{c}0.000 \\
(0.000)\end{array}$ \\
\hline River Length & & & & $\begin{array}{c}0.002^{* * *} \\
(0.000)\end{array}$ & $\begin{array}{r}0.003^{* * *} \\
(0.001)\end{array}$ \\
\hline River Density & & & & $\begin{array}{c}0.029 \\
(0.021)\end{array}$ & $\begin{array}{c}0.031^{*} \\
(0.016)\end{array}$ \\
\hline Share Desert & & & & $\begin{array}{c}0.107 \\
(0.240)\end{array}$ & $\begin{array}{l}-0.088 \\
(0.234)\end{array}$ \\
\hline Average Temperature & & & & & $\begin{array}{r}0.023^{* * *} \\
(0.008)\end{array}$ \\
\hline Temperature Range & & & & & $\begin{array}{l}-0.012 \\
(0.024)\end{array}$ \\
\hline Soil Quality (Climatic) & No & No & Yes & Yes & Yes \\
\hline$N$ & 131 & 131 & 131 & 131 & 131 \\
\hline $1^{\text {st }}$ Stage $F$-statistic $(\mathrm{K}-\mathrm{P})$ & 237.138 & 194.590 & 177.812 & 188.822 & 173.749 \\
\hline
\end{tabular}

This table presents the results of a series of 2SLS regression analyses, on the ethnic-group level, of a measure of pre-colonial jurisdictional hierarchy (the natural logarithm of the number of levels of jurisdictional hierarchy) on observed genetic diversity, instrumented by the migratory distance from East Africa to the interior centroid of the homeland of the ethnicity, conditional on a range of control variables at the ethnic-group level. Heteroscedasticity-consistent standard errors are reported in parentheses. ${ }^{* *}$ Significant at the 1 percent level. $* *$ Significant at the 5 percent level. ${ }^{*}$ Significant at the 10 percent level.

on jurisdictional hierarchy remains highly significant while controlling for absolute latitude of the centroid of the homeland of the ethnicity (column 2), soil quality decile fixed effects (column 3), elevation of the homelands, terrain ruggedness, length and density of rivers, and the share of desert (column 4), average temperature, as well as the temperature range (column 5). In particular, a 1 percentage point increase in observed genetic diversity increases the number of levels of jurisdictional hierarchy by 5.2 percent. $^{17}$

\footnotetext{
${ }^{17}$ In light of the modest sample size of these regressions involving observed population diversity, migratory distance from East Africa is a powerful predictor of population diversity across the globe, but not within continental regions and thus, continental fixed effects cannot be used in these instrumental variable regressions. Reassuringly, however, the subsequent section establishes the causal effect of population diversity while accounting for continental fixed effects.
} 
Table 3: Predicted Population Diversity and Jurisdictional Hierarchy

\begin{tabular}{|c|c|c|c|c|c|c|}
\hline & \multicolumn{6}{|c|}{ Log Number of Levels of Jurisdictional Hierarchy } \\
\hline & (1) & $(2)$ & $(3)$ & $(4)$ & $(5)$ & $(6)$ \\
\hline Predicted Genetic Diversity & $\begin{array}{c}5.121^{* * *} \\
(0.293)\end{array}$ & $\begin{array}{c}5.771^{* * *} \\
(0.320)\end{array}$ & $\begin{array}{c}5.838^{* * *} \\
(0.317)\end{array}$ & $\begin{array}{c}5.496^{* * *} \\
(1.010)\end{array}$ & $\begin{array}{c}5.732^{* * *} \\
(1.097)\end{array}$ & $\begin{array}{c}5.949^{* * *} \\
(1.106)\end{array}$ \\
\hline Log Absolute Latitude & & $\begin{array}{c}0.068^{* * *} \\
(0.013)\end{array}$ & $\begin{array}{c}0.080^{* * *} \\
(0.014)\end{array}$ & $\begin{array}{c}0.110^{* * *} \\
(0.018)\end{array}$ & $\begin{array}{c}0.109^{* * *} \\
(0.019)\end{array}$ & $\begin{array}{c}0.130^{* * *} \\
(0.021)\end{array}$ \\
\hline Elevation & & & & & $\begin{array}{c}0.000 \\
(0.000)\end{array}$ & $\begin{array}{l}0.000^{* *} \\
(0.000)\end{array}$ \\
\hline Terrain Ruggedness & & & & & $\begin{array}{c}-0.000^{*} \\
(0.000)\end{array}$ & $\begin{array}{c}-0.000^{* * *} \\
(0.000)\end{array}$ \\
\hline River Length & & & & & $\begin{array}{l}0.003^{* *} \\
(0.001)\end{array}$ & $\begin{array}{c}0.003^{* * *} \\
(0.001)\end{array}$ \\
\hline River Density & & & & & $\begin{array}{l}-0.003 \\
(0.002)\end{array}$ & $\begin{array}{l}-0.002 \\
(0.002)\end{array}$ \\
\hline Share Desert & & & & & $\begin{array}{c}0.011 \\
(0.062)\end{array}$ & $\begin{array}{c}0.019 \\
(0.072)\end{array}$ \\
\hline Average Temperature & & & & & & $\begin{array}{c}0.007^{*} \\
(0.004)\end{array}$ \\
\hline Temperature Range & & & & & & $\begin{array}{c}-0.020^{* *} \\
(0.008)\end{array}$ \\
\hline Soil Quality (Climatic) & No & No & Yes & Yes & Yes & Yes \\
\hline Continental FE & No & No & No & Yes & Yes & Yes \\
\hline$N$ & 1,076 & 1,076 & 1,076 & 1,076 & 1,076 & 1,076 \\
\hline Adjusted $R^{2}$ & 0.199 & 0.217 & 0.225 & 0.290 & 0.297 & 0.300 \\
\hline
\end{tabular}

This table presents the results of a series of OLS regression analyses, on the ethnic-group level, of a measure of pre-colonial jurisdictional hierarchy (the natural logarithm of the number of levels of jurisdictional hierarchy) on predicted genetic diversity, based on the migratory distance from East Africa to the interior centroid of the homeland of the ethnicity, conditional on a range of control variables at the ethnic-group level. Specifications marked with "Continental FE" accounts for sub-Saharan Africa, Latin America, and continental fixed effects. Heteroscedasticity-consistent standard errors are reported in parentheses. ${ }^{* * *}$ Significant at the 1 percent level. ** Significant at the 5 percent level. * Significant at the 10 percent level.

\subsubsection{Predicted Population Diversity and Jurisdictional Hierarchy}

In light of potential concerns about the endogeneity of observed population diversity and the size and the representativeness of the ethnic group sample with observed population diversity, the third layer of this empirical analysis exploits an additional empirical strategy to identify the causal effect of population diversity on jurisdictional hierarchy and to demonstrate the robustness of the estimated effect. Using migratory distance from Africa to project population diversity for 1,267 ethnic groups in the Ethnographic Atlas, the analysis further establishes the robustness of the highly significant effect of population diversity on jurisdictional hierarchy in this extended sample. 
Table 3 presents the results from OLS regressions of the log number of levels of jurisdictional hierarchy in the pre-colonial era on predicted population diversity using the extended sample with predicted genetic diversity. Reassuringly, in comparison to the estimates in Table 1 and Table 2, the estimated coefficients on predicted genetic diversity in Table 3 are of the same order of magnitude and remain highly statistically significant. Furthermore, the estimates are very stable across specifications.

Column 1 establishes that population diversity, as predicted by migratory distance from East Africa, has a highly statistically and economically significant effect on the log number of levels of jurisdictional hierarchy. In particular, a 1 percentage point increase in the level of predicted population diversity increases the number of levels of jurisdictional hierarchy by 5.1 percent. Furthermore, columns 2-6 establish that this effect is robust to the inclusion of control variables capturing a range of geographical factors. In particular, the estimated effect of predicted genetic diversity on jurisdictional hierarchy remains highly significant while controlling for absolute latitude of the centroid of the homeland of the ethnicity (column 2), soil quality decile fixed effects (column 3), continental fixed effects (column 4), elevation of the homelands, terrain ruggedness, length and density of rivers, and the share of desert (column 5), average temperature, as well as the temperature range (column 6).

Thus, Table 3 establishes that the estimated effect of predicted population diversity on precolonial jurisdictional hierarchy is highly statistically and economically significant, accounting for a wide range of potentially confounding geographical characteristics and continental fixed effects. In particular, the conditional effect of a 1 percentage point increase in predicted population diversity increases the number of levels of jurisdictional hierarchy by 5.9 percent. This partial association between jurisdictional hierarchy and predicted population diversity, derived in column 6 , is plotted in Panel B of Figure A.1.

\subsubsection{Robustness}

The findings are unaffected qualitatively by alternative geographical characteristic that has been shown to be correlated with the emergence of the state in general and the presence of autocracy in particular. First, as suggested by Bentzen et al. (2017) irrigation suitability, and its potential effect on the desirability of cooperation, is associated with the presence of autocracy across contemporary countries and regions. As reported in Tables B.8 and B.9, irrigation suitability is also associated with jurisdictional hierarchy across ethnic groups. Nevertheless, accounting for the potentially confounding effect of irrigation suitability does not alter the qualitative impact of population diversity on jurisdictional hierarchy in the predicted as well as the observed samples. Furthermore, in line with the proposed hypothesis about the contribution of population diversity for the scope for domination, the interaction between genetic diversity and irrigation suitability is positive and highly significant (Table B.10). Moreover, the association between irrigation suitability and jurisdictional hierarchy becomes significantly positive only in sufficiently diverse societies. 
Second, as suggested by Fenske (2014), ecological diversity is associated with jurisdictional hierarchy. Nevertheless, accounting for the potentially confounding effect of ecological diversity does not alter the qualitative impact of population diversity on jurisdictional hierarchy in the predicted as well as the observed samples (Tables B.11 and B.12). Third, as proposed by Mayshar et al. (2015), the suitability of land for tubers is associated with jurisdictional hierarchy. Accounting for the potentially confounding effect of major crop types does not alter the qualitative impact of population diversity on jurisdictional hierarchy in the predicted as well as the observed samples (Tables B.13 and B.14).

The findings are robust to additional confounding geographical and ethnographic characteristics. First, variability of soil suitability that, as established by Michalopoulos (2012), contributes to ethnolinguistic fractionalization and thus population diversity has no qualitative impact on the findings (Tables B.15 and B.16). Second, while the scale of each society may be associated with jurisdictional hierarchy, it has no qualitative impact on the effect of population diversity on jurisdictional hierarchy (Tables B.17 and B.18). Third, the exclusion of the African continent has no impact on the qualitative results (Tables B.19 and B.20). Fourth, the year of description of each ethnic group, as recorded in the Ethnographic Atlas, has no qualitative impact on the findings (Tables B.21 and B.22).

The findings are further robust to alternative specifications and estimation methods. In particular, the use of ordered probit rather than OLS has no impact on the results (Table B.5 and B.4), and the analysis is unaffected by the use of the number (rather than the logarithm of the number) of levels of jurisdictional hierarchy as the outcome variable (Tables B.23 and B.24).

\subsection{Population Diversity and Social Stratification Slavery}

This subsection establishes the effect of population diversity on the pre-colonial the degree of social stratification and slavery across ethnic groups.

\subsubsection{Observed Population Diversity and Social Stratification Slavery}

The first layer of this empirical analysis establishes that ethnic groups that are characterized by a higher level of observed population diversity tend to be characterized by a higher degree of social stratification and by the presence of slavery.

Table 4 presents the results from OLS regression analyses of social stratification and slavery in the pre-colonial era on observed population diversity. Consistent with the prediction of the proposed hypothesis, columns 1-3 establish a highly statistically and economically significant correlation between the measure of social stratification and observed genetic diversity, based on the 121 ethnic groups for which information on both population diversity and social stratification are available. Column 1 presents the correlation accounting for absolute latitude. Column 2 establishes that the association remains highly statistically significant while accounting for the baseline geographical controls, and column 3 establishes robustness of the association to the inclusion of continental fixed

effects. The point estimate implies that a 1 percent increase in observed population diversity is 
Table 4: Observed Genetic Diversity and Stratification \& Slavery

\begin{tabular}{|c|c|c|c|c|c|c|}
\hline & \multicolumn{3}{|c|}{$\begin{array}{c}\text { Social } \\
\text { Stratification }\end{array}$} & \multicolumn{3}{|c|}{$\begin{array}{c}\text { Intensity of } \\
\text { Slavery }\end{array}$} \\
\hline & (1) & $(2)$ & $(3)$ & $(4)$ & $(5)$ & $(6)$ \\
\hline Genetic Diversity & $\begin{array}{c}5.663^{* * *} \\
(1.511)\end{array}$ & $\begin{array}{c}6.549^{* * *} \\
(2.076)\end{array}$ & $\begin{array}{c}22.740^{* * *} \\
(5.371)\end{array}$ & $\begin{array}{c}7.239^{* * *} \\
(1.373)\end{array}$ & $\begin{array}{c}9.191^{* * *} \\
(2.078)\end{array}$ & $\begin{array}{c}11.406^{*} \\
(6.149)\end{array}$ \\
\hline Log Absolute Latitude & $\begin{array}{c}0.263^{* * *} \\
(0.056)\end{array}$ & $\begin{array}{c}0.388^{* * *} \\
(0.084)\end{array}$ & $\begin{array}{c}0.277^{* * *} \\
(0.091)\end{array}$ & $\begin{array}{c}0.188^{* * *} \\
(0.053)\end{array}$ & $\begin{array}{c}0.278^{* * *} \\
(0.080)\end{array}$ & $\begin{array}{c}0.338^{* * *} \\
(0.104)\end{array}$ \\
\hline Elevation & & $\begin{array}{c}0.000^{* *} \\
(0.000)\end{array}$ & $\begin{array}{c}0.000 \\
(0.000)\end{array}$ & & $\begin{array}{c}0.000 \\
(0.000)\end{array}$ & $\begin{array}{c}0.000 \\
(0.000)\end{array}$ \\
\hline Terrain Ruggedness & & $\begin{array}{c}0.000 \\
(0.000)\end{array}$ & $\begin{array}{c}0.000 \\
(0.000)\end{array}$ & & $\begin{array}{c}0.000 \\
(0.000)\end{array}$ & $\begin{array}{c}0.000 \\
(0.000)\end{array}$ \\
\hline River Length & & $\begin{array}{c}0.003^{* * *} \\
(0.001)\end{array}$ & $\begin{array}{c}0.002^{* * *} \\
(0.001)\end{array}$ & & $\begin{array}{l}-0.001 \\
(0.001)\end{array}$ & $\begin{array}{l}-0.001 \\
(0.001)\end{array}$ \\
\hline River Density & & $\begin{array}{c}0.004 \\
(0.035)\end{array}$ & $\begin{array}{c}0.045 \\
(0.043)\end{array}$ & & $\begin{array}{c}0.079^{* *} \\
(0.034)\end{array}$ & $\begin{array}{c}0.086^{* *} \\
(0.040)\end{array}$ \\
\hline Share Desert & & $\begin{array}{c}-0.804^{* *} \\
(0.365)\end{array}$ & $\begin{array}{c}-1.874^{* * *} \\
(0.363)\end{array}$ & & $\begin{array}{l}-0.066 \\
(0.467)\end{array}$ & $\begin{array}{c}0.293 \\
(0.578)\end{array}$ \\
\hline Average Temperature & & $\begin{array}{c}0.052^{* * *} \\
(0.012)\end{array}$ & $\begin{array}{c}0.055^{* * *} \\
(0.015)\end{array}$ & & $\begin{array}{c}0.039^{* * *} \\
(0.011)\end{array}$ & $\begin{array}{c}0.025 \\
(0.016)\end{array}$ \\
\hline Temperature Range & & $\begin{array}{l}-0.077^{*} \\
(0.045)\end{array}$ & $\begin{array}{l}-0.022 \\
(0.042)\end{array}$ & & $\begin{array}{l}-0.013 \\
(0.039)\end{array}$ & $\begin{array}{l}-0.031 \\
(0.042)\end{array}$ \\
\hline Soil Quality (Climatic) & Yes & Yes & Yes & Yes & Yes & Yes \\
\hline Continental FE & No & No & Yes & No & No & Yes \\
\hline$N$ & 121 & 121 & 121 & 120 & 120 & 120 \\
\hline Adjusted $R^{2}$ & 0.155 & 0.218 & 0.322 & 0.182 & 0.277 & 0.285 \\
\hline
\end{tabular}

associated with a 0.23 higher score on the social stratification scale. ${ }^{18}$ This partial association between social stratification and population diversity is plotted in Panel A of Figure A.2.

Similarly, columns 4-6 establish that there is a highly statistically and economically significant correlation between population diversity and the intensity of slavery, based on the 120 ethnic groups for which information on both measures is available. Column 4 presents the correlation accounting for absolute latitude. Column 5 establishes that the association remains highly statistically

\footnotetext{
${ }^{18}$ It should be noted that the estimated effect is much larger within continents compared to the estimated effect across the world as a whole.
} 
significant while accounting for the baseline geographical controls, and column 6 establishes that the association remains highly statistically significant when also accounting for continental fixed effects. The point estimate implies that a 1 percent increase in observed population diversity is associated with a 0.11 higher score on the intensity of slavery. ${ }^{19}$

\subsubsection{Observed Diversity and Social Stratification \& Slavery: IV Analysis}

In light of potential concerns about the endogeneity of observed population diversity, the second layer of this empirical analysis exploits an instrumental variable strategy to identify the causal effect of population diversity on social stratification and slavery. In view of the negative effect of migratory distance from the cradle of humankind in East Africa to various settlements across the globe on population diversity, migratory distance from Africa is exploited as an instrumental variable for observed population diversity, establishing a highly significant causal effect of diversity on the degree of social stratification and slavery.

Table 5 presents the results from a series of 2SLS regressions. The table reveals that the effect of genetic diversity on social stratification and the intensity of slavery is statistically significant. In particular, column 1 establishes that migratory distance from East Africa is a very strong instrument for genetic diversity (the Kleibergen-Paap $F$-statistic is 156) and that there is a statistically and economically significant effect of observed genetic diversity on social stratification, controlling for absolute latitude. Furthermore, column 2 establishes that the order of magnitude and the significance of the estimate is robust to the inclusion of the baseline geographical controls. The point estimate implies that a 1 percent increase in observed population diversity is associated with a 0.05 higher score on the social stratification scale.

Similarly, column 3 establishes that there is a highly statistically and economically significant effect of observed genetic diversity on the intensity of slavery, controlling for absolute latitude, while column 4 establishes that the order of magnitude and the significance of the estimate is robust to the inclusion of the baseline geographical controls. The point estimate implies that a 1 percent increase in observed population diversity is associated with a 0.08 higher score on the intensity of slavery scale.

\subsubsection{Predicted Population Diversity and Stratification \& Slavery}

In light of potential concerns about the endogeneity of observed population diversity and the size and the representativeness of the ethnic group sample with observed population diversity, the third layer of this empirical analysis exploits an additional empirical strategy to identify the causal effect of population diversity on social stratification and the degree of slavery and to demonstrate the robustness of the estimated effect. Using migratory distance from Africa to project population diversity for 1,267 ethnic groups in the Ethnographic Atlas, the analysis further establishes the

\footnotetext{
${ }^{19}$ It should be noted that the estimated effect is much larger within continents compared to the estimated effect across the world as a whole.
} 
Table 5: Observed Population Diversity and Stratification \& Slavery - Instrumental Variable Analysis

\begin{tabular}{|c|c|c|c|c|}
\hline & \multicolumn{2}{|c|}{$\begin{array}{c}\text { Social } \\
\text { Stratification }\end{array}$} & \multicolumn{2}{|c|}{$\begin{array}{c}\text { Intensity of } \\
\text { Slavery }\end{array}$} \\
\hline & (1) & $(2)$ & $(3)$ & $(4)$ \\
\hline Genetic Diversity & $\begin{array}{l}4.418^{* *} \\
(1.753)\end{array}$ & $\begin{array}{l}4.856^{* *} \\
(2.184)\end{array}$ & $\begin{array}{c}6.874^{* * *} \\
(1.817)\end{array}$ & $\begin{array}{c}7.816^{* * *} \\
(2.493)\end{array}$ \\
\hline Log Absolute Latitude & $\begin{array}{r}0.251^{* * *} \\
(0.054)\end{array}$ & $\begin{array}{c}0.380^{* * *} \\
(0.076)\end{array}$ & $\begin{array}{c}0.185^{* * *} \\
(0.050)\end{array}$ & $\begin{array}{c}0.272^{* * *} \\
(0.072)\end{array}$ \\
\hline Elevation & & $\begin{array}{l}0.000^{* *} \\
(0.000)\end{array}$ & & $\begin{array}{c}0.000 \\
(0.000)\end{array}$ \\
\hline Terrain Ruggedness & & $\begin{array}{l}-0.000 \\
(0.000)\end{array}$ & & $\begin{array}{c}0.000 \\
(0.000)\end{array}$ \\
\hline River Length & & $\begin{array}{c}0.003^{* * *} \\
(0.001)\end{array}$ & & $\begin{array}{l}-0.001^{*} \\
(0.001)\end{array}$ \\
\hline River Density & & $\begin{array}{l}-0.013 \\
(0.031)\end{array}$ & & $\begin{array}{l}0.065^{*} \\
(0.035)\end{array}$ \\
\hline Share Desert & & $\begin{array}{c}-0.771^{* *} \\
(0.337)\end{array}$ & & $\begin{array}{l}-0.042 \\
(0.422)\end{array}$ \\
\hline Average Temperature & & $\begin{array}{c}0.052^{* * *} \\
(0.011)\end{array}$ & & $\begin{array}{c}0.040^{* * *} \\
(0.010)\end{array}$ \\
\hline Temperature Range & & $\begin{array}{l}-0.075^{*} \\
(0.042) \\
\end{array}$ & & $\begin{array}{l}-0.012 \\
(0.035) \\
\end{array}$ \\
\hline Soil Quality (Climatic) & Yes & Yes & Yes & Yes \\
\hline$N$ & 121 & 121 & 120 & 120 \\
\hline $1^{\text {st }}$ Stage $F$-statistic (K-P) & 156.101 & 151.207 & 168.137 & 155.249 \\
\hline
\end{tabular}

This table presents the results of a series of 2SLS regression analyses, on the ethnicgroup level, of measures of pre-colonial stratification and inequality on observed genetic diversity, instrumented by the migratory distance from East Africa to the interior centroid of the homeland of the ethnicity, conditional on a range of control variables at the ethnic-group level. Heteroscedasticity-consistent standard errors are reported in parentheses. $* * *$ Significant at the 1 percent level. ** Significant at the 5 percent level. * Significant at the 10 percent level.

robustness of the highly significant effect of population diversity on social stratification and the degree of slavery in this extended sample.

Table 6 presents the results from OLS regressions of social stratification and slavery in the pre-colonial era using the extended sample of predicted population diversity. Reassuringly, in comparison to the estimates in Table 4 and Table 5, the estimated coefficients on predicted genetic diversity in Table 6 are largely of the same order of magnitude and remain highly statistically significant. Furthermore, the estimates are very stable across specifications. In particular, columns 
Table 6: Predicted Population Diversity and Stratification \& Inequality

\begin{tabular}{|c|c|c|c|c|c|c|}
\hline & \multicolumn{3}{|c|}{$\begin{array}{c}\text { Social } \\
\text { Stratification }\end{array}$} & \multicolumn{3}{|c|}{$\begin{array}{c}\text { Intensity of } \\
\text { Slavery }\end{array}$} \\
\hline & (1) & $(2)$ & $(3)$ & $(4)$ & $(5)$ & (6) \\
\hline Predicted Genetic Diversity & $\begin{array}{r}6.845^{* * *} \\
(0.555)\end{array}$ & $\begin{array}{c}6.529^{* * *} \\
(0.553)\end{array}$ & $\begin{array}{c}9.520^{* * *} \\
(2.000)\end{array}$ & $\begin{array}{c}8.066^{* * *} \\
(0.557)\end{array}$ & $\begin{array}{c}7.618^{* * *} \\
(0.571)\end{array}$ & $\begin{array}{c}7.534^{* * *} \\
(2.172)\end{array}$ \\
\hline Log Absolute Latitude & $\begin{array}{r}0.182^{* * *} \\
(0.022)\end{array}$ & $\begin{array}{c}0.257^{* * *} \\
(0.035)\end{array}$ & $\begin{array}{c}0.251^{* * *} \\
(0.037)\end{array}$ & $\begin{array}{c}0.027 \\
(0.024)\end{array}$ & $\begin{array}{c}0.152^{* * *} \\
(0.032)\end{array}$ & $\begin{array}{r}0.198^{* * *} \\
(0.035)\end{array}$ \\
\hline Elevation & & $\begin{array}{c}0.000 \\
(0.000)\end{array}$ & $\begin{array}{c}0.000 \\
(0.000)\end{array}$ & & $\begin{array}{c}0.000 \\
(0.000)\end{array}$ & $\begin{array}{c}0.000 \\
(0.000)\end{array}$ \\
\hline Terrain Ruggedness & & $\begin{array}{c}0.000^{* * *} \\
(0.000)\end{array}$ & $\begin{array}{l}0.000^{* *} \\
(0.000)\end{array}$ & & $\begin{array}{l}0.000^{*} \\
(0.000)\end{array}$ & $\begin{array}{c}0.000^{* * *} \\
(0.000)\end{array}$ \\
\hline River Length & & $\begin{array}{c}0.003^{* *} \\
(0.001)\end{array}$ & $\begin{array}{l}0.003^{* *} \\
(0.001)\end{array}$ & & $\begin{array}{l}-0.001 \\
(0.001)\end{array}$ & $\begin{array}{l}-0.000 \\
(0.001)\end{array}$ \\
\hline River Density & & $\begin{array}{l}-0.003 \\
(0.002)\end{array}$ & $\begin{array}{c}-0.005^{* *} \\
(0.002)\end{array}$ & & $\begin{array}{l}-0.000 \\
(0.005)\end{array}$ & $\begin{array}{c}0.001 \\
(0.003)\end{array}$ \\
\hline Share Desert & & $\begin{array}{l}-0.064 \\
(0.109)\end{array}$ & $\begin{array}{l}-0.212^{*} \\
(0.124)\end{array}$ & & $\begin{array}{l}-0.116 \\
(0.113)\end{array}$ & $\begin{array}{c}0.047 \\
(0.123)\end{array}$ \\
\hline Average Temperature & & $\begin{array}{c}0.018^{* * *} \\
(0.005)\end{array}$ & $\begin{array}{c}0.019^{* * *} \\
(0.006)\end{array}$ & & $\begin{array}{c}0.026^{* * *} \\
(0.004)\end{array}$ & $\begin{array}{c}0.019^{* * *} \\
(0.006)\end{array}$ \\
\hline Temperature Range & & $\begin{array}{c}-0.090^{* * *} \\
(0.014)\end{array}$ & $\begin{array}{c}-0.068^{* * *} \\
(0.016)\end{array}$ & & $\begin{array}{c}-0.052^{* * *} \\
(0.013)\end{array}$ & $\begin{array}{c}-0.077^{* * *} \\
(0.014)\end{array}$ \\
\hline Soil Quality (Climatic) & Yes & Yes & Yes & Yes & Yes & Yes \\
\hline Continental FE & No & No & Yes & No & No & Yes \\
\hline$N$ & 982 & 982 & 982 & 979 & 979 & 979 \\
\hline Adjusted $R^{2}$ & 0.127 & 0.215 & 0.229 & 0.208 & 0.266 & 0.330 \\
\hline
\end{tabular}

This table presents the results of a series of OLS regression analyses, on the ethnic-group level, of measures of pre-colonial stratification and inequality on predicted genetic diversity, based on the migratory distance from East Africa to the interior centroid of the homeland of the ethnicity, conditional on a range of control variables at the ethnic-group level. Specifications marked with "Continental FE" accounts for sub-Saharan Africa, Latin America, and continental fixed effects. Heteroscedasticity-consistent standard errors are reported in parentheses. $* * *$ Significant at the 1 percent level. $* *$ Significant at the 5 percent level. ${ }^{*}$ Significant at the 10 percent level.

1-3 establish that predicted population diversity has a highly statistically and economically significant effect on the measure of social stratification. Column 1 presents the effect accounting for absolute latitude. Column 2 establishes that the point estimate is very similar and remains highly significant in the presence of the baseline geographical control variables, and column 3 establishes that the point estimate is of the same order of magnitude and remain highly significant as one accounts for continental fixed effects. This partial association between social stratification and population diversity is plotted in Panel B of Figure A.2. 
Similarly, columns 4 to 6 establish that predicted population diversity has a highly statistically and economically significant effect on the intensity of slavery. Column 5 establishes that the point estimate is very similar and remains highly significant in the presence of the baseline controls. Furthermore, column 6 establishes that the point estimate is nearly unchanged and remains highly significant as one accounts for continental fixed effects.

Thus, Table 6 establishes that the estimated effect of predicted population diversity on precolonial social stratification and slavery is highly statistically and economically significant, accounting for a wide range of potentially confounding geographical characteristics and continental fixed effects. In particular, a 1 percentage point increase in predicted population diversity increases the score on the social stratification index by 0.1 and the intensity of slavery index by 0.08 .

\subsection{Jurisdictional Hierarchy, Stratification, \& Pre-Colonial Autocracy}

This part of the pre-colonial ethnic-level empirical analysis explores the association between the emergence of intuitions as well as the degree of social stratification with the emergence of precolonial autocratic institutions. In line with the proposed mechanism, the empirical analysis establishes that the number of levels of jurisdictional hierarchy and the degree of social stratification and slavery are associated with the presence of pre-colonial autocratic institutions, as captured by: (i) degree of absence of checks on leader's power, (ii) difficulty of removal of leaders, (iii) leader's exercise of authority, (iv) degree of lack of community decisions, and (v) perception of leader's power. Moreover, the empirical analysis establishes the reduced form effect of predicted population diversity on each of these measures of pre-colonial autocracy.

\subsubsection{Jurisdictional Hierarchy and Pre-Colonial Autocratic Institutions}

The first layer of this empirical analysis establishes that the number of levels of jurisdictional hierarchy is associated with the presence of pre-colonial autocratic institutions.

Table 7 presents the results from OLS regression analyses of the various measures of precolonial autocratic institutions on jurisdictional hierarchy. ${ }^{20}$ Columns 1 and 2 establish that precolonial jurisdictional hierarchy is highly significantly associated with the degree of absence of checks on the leader's power. Columns 3 and 4 suggest that pre-colonial jurisdictional hierarchy is highly significantly associated with the difficulty of removal of leaders. Columns 5 and 6 find that pre-colonial jurisdictional hierarchy is highly significantly associated with the leader's exercise of authority. Columns 7 and 8 establish that pre-colonial jurisdictional hierarchy is highly significantly associated with the degree of lack of community decisions. Finally, columns 9 and 10 suggest that pre-colonial jurisdictional hierarchy is highly significantly associated with the perception of the leader's power.

\footnotetext{
${ }^{20}$ Given the limited number of observations in the SCCS-dataset, the analysis cannot account for continental fixed effects.
} 
Table 7: Jurisdictional Hierarchy and Autocratic Institutions

\begin{tabular}{|c|c|c|c|c|c|c|c|c|c|c|}
\hline & \multicolumn{2}{|c|}{$\begin{array}{c}\text { Degree of Absence } \\
\text { of Checks on } \\
\text { Leader's Power }\end{array}$} & \multicolumn{2}{|c|}{$\begin{array}{l}\text { Difficulty of } \\
\text { Removal of } \\
\text { Leaders }\end{array}$} & \multicolumn{2}{|c|}{$\begin{array}{l}\text { Leader's Exercise } \\
\text { of Authority }\end{array}$} & \multicolumn{2}{|c|}{$\begin{array}{c}\text { Degree of Lack of } \\
\text { Community } \\
\text { Decisions }\end{array}$} & \multicolumn{2}{|c|}{$\begin{array}{l}\text { Perception of } \\
\text { Leader's Power }\end{array}$} \\
\hline & $(1)$ & $(2)$ & $(3)$ & $(4)$ & $(5)$ & $(6)$ & $(7)$ & $(8)$ & $(9)$ & $(10)$ \\
\hline Log Levels of Jurisdictional Hierarchy & $\begin{array}{c}0.853^{* * *} \\
(0.166)\end{array}$ & $\begin{array}{c}0.738^{* * *} \\
(0.167)\end{array}$ & $\begin{array}{c}0.941^{* * *} \\
(0.206)\end{array}$ & $\begin{array}{c}0.802^{* * *} \\
(0.212)\end{array}$ & $\begin{array}{c}0.947^{* * *} \\
(0.133)\end{array}$ & $\begin{array}{c}0.904^{* * *} \\
(0.145)\end{array}$ & $\begin{array}{c}0.907^{* * *} \\
(0.136)\end{array}$ & $\begin{array}{c}0.896^{* * *} \\
(0.155)\end{array}$ & $\begin{array}{c}0.842^{* * *} \\
(0.145)\end{array}$ & $\begin{array}{r}0.841^{* * *} \\
(0.157)\end{array}$ \\
\hline Log Absolute Latitude & $\begin{array}{l}-0.030 \\
(0.083)\end{array}$ & $\begin{array}{l}-0.119 \\
(0.149)\end{array}$ & $\begin{array}{c}0.061 \\
(0.088)\end{array}$ & $\begin{array}{c}0.069 \\
(0.142)\end{array}$ & $\begin{array}{l}-0.116 \\
(0.070)\end{array}$ & $\begin{array}{l}-0.071 \\
(0.123)\end{array}$ & $\begin{array}{c}-0.162^{* *} \\
(0.063)\end{array}$ & $\begin{array}{l}-0.100 \\
(0.097)\end{array}$ & $\begin{array}{l}-0.026 \\
(0.074)\end{array}$ & $\begin{array}{c}0.039 \\
(0.115)\end{array}$ \\
\hline Elevation & & $\begin{array}{l}-0.000 \\
(0.000)\end{array}$ & & $\begin{array}{l}-0.000 \\
(0.000)\end{array}$ & & $\begin{array}{l}-0.000 \\
(0.000)\end{array}$ & & $\begin{array}{c}0.000 \\
(0.000)\end{array}$ & & $\begin{array}{c}0.000 \\
(0.000)\end{array}$ \\
\hline Terrain Ruggedness & & $\begin{array}{c}0.000 \\
(0.000)\end{array}$ & & $\begin{array}{l}0.000^{*} \\
(0.000)\end{array}$ & & $\begin{array}{c}0.000 \\
(0.000)\end{array}$ & & $\begin{array}{c}0.000 \\
(0.000)\end{array}$ & & $\begin{array}{l}-0.000 \\
(0.000)\end{array}$ \\
\hline River Length & & $\begin{array}{c}0.007 \\
(0.007)\end{array}$ & & $\begin{array}{l}-0.008 \\
(0.010)\end{array}$ & & $\begin{array}{l}-0.000 \\
(0.005)\end{array}$ & & $\begin{array}{l}-0.007 \\
(0.007)\end{array}$ & & $\begin{array}{c}0.006 \\
(0.006)\end{array}$ \\
\hline River Density & & $\begin{array}{l}-0.022 \\
(0.050)\end{array}$ & & $\begin{array}{l}-0.001 \\
(0.033)\end{array}$ & & $\begin{array}{c}0.003 \\
(0.032)\end{array}$ & & $\begin{array}{c}0.032 \\
(0.032)\end{array}$ & & $\begin{array}{c}0.002 \\
(0.030)\end{array}$ \\
\hline Share Desert & & $\begin{array}{c}0.293 \\
(0.462)\end{array}$ & & $\begin{array}{c}0.271 \\
(0.578)\end{array}$ & & $\begin{array}{l}-0.509 \\
(0.453)\end{array}$ & & $\begin{array}{c}0.100 \\
(0.389)\end{array}$ & & $\begin{array}{c}0.149 \\
(0.426)\end{array}$ \\
\hline Average Temperature & & $\begin{array}{l}-0.004 \\
(0.016)\end{array}$ & & $\begin{array}{c}0.012 \\
(0.017)\end{array}$ & & $\begin{array}{c}0.018 \\
(0.015)\end{array}$ & & $\begin{array}{c}0.012 \\
(0.012)\end{array}$ & & $\begin{array}{c}0.008 \\
(0.014)\end{array}$ \\
\hline Temperature Range & & $\begin{array}{c}0.079 \\
(0.060) \\
\end{array}$ & & $\begin{array}{c}0.058 \\
(0.067) \\
\end{array}$ & & $\begin{array}{c}0.048 \\
(0.057) \\
\end{array}$ & & $\begin{array}{c}-0.016 \\
(0.050)\end{array}$ & & $\begin{array}{c}-0.051 \\
(0.044)\end{array}$ \\
\hline Soil Quality (Climatic) & Yes & Yes & Yes & Yes & Yes & Yes & Yes & Yes & Yes & Yes \\
\hline$N$ & 78 & 78 & 71 & 71 & 79 & 79 & 82 & 82 & 82 & 82 \\
\hline Adjusted $R^{2}$ & 0.223 & 0.243 & 0.207 & 0.271 & 0.360 & 0.338 & 0.391 & 0.360 & 0.341 & 0.286 \\
\hline
\end{tabular}

This table presents the results of a series of OLS regression analyses, on the ethnic-group level, of measures of pre-colonial autocracy on a measure of pre-colonial jurisdictional hierarchy (the natural logarithm of the number of levels of jurisdictional hierarchy), conditional on a range of control variables at the ethnic-group level. Heteroscedasticity-consistent standard errors are reported in parentheses. *** Significant at the 1 percent level. ${ }^{* *}$ Significant at the 5 percent level. * Significant at the 10 percent level. 
Thus, Table 7 establishes that jurisdictional hierarchy, as reflected by the number of levels of jurisdictional hierarchy, is highly statistically significantly associated with the various measures of pre-colonial autocratic institutions.

\subsubsection{Stratification and Pre-Colonial Autocratic Institutions}

The second layer of this empirical analysis establishes that the degree of social stratification and slavery is associated with presence of pre-colonial autocratic institutions.

As presented in Table 8, social stratification is significantly associated with the degree of absence of checks on the leader's power (columns 1 and 2), and highly significantly associated with the difficulty of removal of leaders (columns 3 and 4); the leader's exercise of authority (columns 5 and 6 ); the degree of lack of community decisions (columns 7 and 8); the perception of the leader's power (columns and 10).

As presented in Table 9, the intensity of slavery is highly significantly associated with: the degree of absence of checks on the leader's power (columns 1 and 2); the difficulty of removal of leaders (columns 3 and 4); the leader's exercise of authority (columns 5 and 6); the degree of lack of community decisions (columns 7 and 8); the perception of the leader's power (columns and 10).

Thus, Table 8 and Table 9 establish that the associations between social stratification, the intensity of slavery, and various measures of pre-colonial autocratic institutions are mostly highly statistically significant.

\subsubsection{Predicted Genetic Diversity and Pre-Colonial Autocracy}

The third layer of this empirical analysis establishes that predicted population diversity has a positive effect on presence of pre-colonial autocratic institutions. Given the limited number of observations in the SCCS-dataset, the analysis uses predicted diversity, rather than the observed one. $^{21}$

As reported in Table 10, predicted population diversity has a significant effect on the degree of absence of checks on the leader's power (columns 1 and 2); the difficulty of removal of leaders (columns 3 and 4); the leader's exercise of authority (columns 5 and 6); the degree of lack of community decisions (columns 7 and 8); the perception of the leader's power (columns and 10). ${ }^{22}$ Overall, Table 10 establishes that predicted population diversity has significant effects on the various measures of pre-colonial autocratic institutions.

\footnotetext{
${ }^{21}$ Table B.26 in the appendix establishes that observed population diversity is associated with pre-colonial autocracy if the measure of "Succession to the Office of Local Headman" from the Ethnographic Atlas is used to proxy for pre-colonial autocracy.

${ }^{22}$ It should be noted that the effect of predicted population diversity on pre-colonial autocracy is not quadratic. In particular, if predicted genetic diversity squared is included to the baseline specifications, the estimated coefficient of this square term is insignificant in all specifications.
} 
Table 8: Social Strata and Autocratic Institutions

\begin{tabular}{|c|c|c|c|c|c|c|c|c|c|c|}
\hline & \multicolumn{2}{|c|}{$\begin{array}{c}\text { Degree of Absence } \\
\text { of Checks on } \\
\text { Leader's Power } \\
\end{array}$} & \multicolumn{2}{|c|}{$\begin{array}{c}\text { Difficulty of } \\
\text { Removal of } \\
\text { Leaders }\end{array}$} & \multicolumn{2}{|c|}{$\begin{array}{l}\text { Leader's Exercise } \\
\text { of Authority }\end{array}$} & \multicolumn{2}{|c|}{$\begin{array}{c}\text { Degree of Lack of } \\
\text { Community } \\
\text { Decisions }\end{array}$} & \multicolumn{2}{|c|}{$\begin{array}{l}\text { Perception of } \\
\text { Leader's Power }\end{array}$} \\
\hline & $(1)$ & $(2)$ & $(3)$ & (4) & $(5)$ & $(6)$ & $(7)$ & $(8)$ & $(9)$ & $(10)$ \\
\hline Social Stratification & $\begin{array}{c}0.532^{* * *} \\
(0.099)\end{array}$ & $\begin{array}{c}0.480^{* * *} \\
(0.104)\end{array}$ & $\begin{array}{c}0.532^{* * *} \\
(0.122)\end{array}$ & $\begin{array}{c}0.412^{* * *} \\
(0.149)\end{array}$ & $\begin{array}{c}0.486^{* * *} \\
(0.095)\end{array}$ & $\begin{array}{c}0.451^{* * *} \\
(0.109)\end{array}$ & $\begin{array}{c}0.507^{* * *} \\
(0.086)\end{array}$ & $\begin{array}{c}0.537^{* * *} \\
(0.103)\end{array}$ & $\begin{array}{c}0.428^{* * *} \\
(0.103)\end{array}$ & $\begin{array}{c}0.504^{* * *} \\
(0.104)\end{array}$ \\
\hline Log Absolute Latitude & $\begin{array}{c}-0.053 \\
(0.089)\end{array}$ & $\begin{array}{c}-0.064 \\
(0.153)\end{array}$ & $\begin{array}{c}0.057 \\
(0.090)\end{array}$ & $\begin{array}{c}0.093 \\
(0.138)\end{array}$ & $\begin{array}{l}-0.132 \\
(0.082)\end{array}$ & $\begin{array}{c}-0.029 \\
(0.139)\end{array}$ & $\begin{array}{c}-0.189^{* * *} \\
(0.065)\end{array}$ & $\begin{array}{c}-0.066 \\
(0.099)\end{array}$ & $\begin{array}{l}-0.049 \\
(0.077)\end{array}$ & $\begin{array}{c}0.071 \\
(0.119)\end{array}$ \\
\hline Elevation & & $\begin{array}{c}0.000 \\
(0.000)\end{array}$ & & $\begin{array}{c}0.000 \\
(0.000)\end{array}$ & & $\begin{array}{c}0.000 \\
(0.000)\end{array}$ & & $\begin{array}{c}0.000^{*} \\
(0.000)\end{array}$ & & $\begin{array}{c}0.001^{* *} \\
(0.000)\end{array}$ \\
\hline Terrain Ruggedness & & $\begin{array}{c}0.000 \\
(0.000)\end{array}$ & & $\begin{array}{c}0.000 \\
(0.000)\end{array}$ & & $\begin{array}{c}0.000 \\
(0.000)\end{array}$ & & $\begin{array}{c}-0.000 \\
(0.000)\end{array}$ & & $\begin{array}{c}-0.000^{* *} \\
(0.000)\end{array}$ \\
\hline River Length & & $\begin{array}{c}0.012 \\
(0.008)\end{array}$ & & $\begin{array}{l}-0.002 \\
(0.010)\end{array}$ & & $\begin{array}{c}0.007 \\
(0.007)\end{array}$ & & $\begin{array}{l}-0.000 \\
(0.006)\end{array}$ & & $\begin{array}{l}0.012^{*} \\
(0.007)\end{array}$ \\
\hline River Density & & $\begin{array}{c}-0.004 \\
(0.049)\end{array}$ & & $\begin{array}{c}0.011 \\
(0.035)\end{array}$ & & $\begin{array}{c}0.012 \\
(0.033)\end{array}$ & & $\begin{array}{c}0.044 \\
(0.039)\end{array}$ & & $\begin{array}{c}0.013 \\
(0.035)\end{array}$ \\
\hline Share Desert & & $\begin{array}{c}0.537 \\
(0.455)\end{array}$ & & $\begin{array}{c}0.338 \\
(0.617)\end{array}$ & & $\begin{array}{l}-0.388 \\
(0.532)\end{array}$ & & $\begin{array}{c}0.287 \\
(0.434)\end{array}$ & & $\begin{array}{c}0.324 \\
(0.447)\end{array}$ \\
\hline Average Temperature & & $\begin{array}{c}0.003 \\
(0.017)\end{array}$ & & $\begin{array}{c}0.016 \\
(0.018)\end{array}$ & & $\begin{array}{c}0.024 \\
(0.017)\end{array}$ & & $\begin{array}{c}0.018 \\
(0.013)\end{array}$ & & $\begin{array}{c}0.013 \\
(0.016)\end{array}$ \\
\hline Temperature Range & & $\begin{array}{c}0.015 \\
(0.057)\end{array}$ & & $\begin{array}{c}0.036 \\
(0.069)\end{array}$ & & $\begin{array}{c}0.002 \\
(0.057)\end{array}$ & & $\begin{array}{l}-0.079^{*} \\
(0.044)\end{array}$ & & $\begin{array}{c}-0.109^{* *} \\
(0.047)\end{array}$ \\
\hline Soil Quality (Climatic) & Yes & Yes & Yes & Yes & Yes & Yes & Yes & Yes & Yes & Yes \\
\hline$N$ & 78 & 78 & 71 & 71 & 79 & 79 & 82 & 82 & 82 & 82 \\
\hline Adjusted $R^{2}$ & 0.245 & 0.254 & 0.167 & 0.200 & 0.256 & 0.206 & 0.345 & 0.325 & 0.260 & 0.258 \\
\hline
\end{tabular}

This table presents the results of a series of OLS regression analyses, on the ethnic-group level, of measures of pre-colonial autocracy on a measure of pre-colonial social stratification, conditional on a range of control variables at the ethnic-group level. Heteroscedasticity-consistent standard errors are reported in parentheses. ${ }^{* * *}$ Significant at the 1 percent level. $* *$ Significant at the 5 percent level. $*$ Significant at the 10 percent level. 
Table 9: Slavery and Autocratic Institutions

\begin{tabular}{|c|c|c|c|c|c|c|c|c|c|c|}
\hline & \multicolumn{2}{|c|}{$\begin{array}{c}\text { Degree of Absence } \\
\text { of Checks on } \\
\text { Leader's Power }\end{array}$} & \multicolumn{2}{|c|}{$\begin{array}{l}\text { Difficulty of } \\
\text { Removal of } \\
\text { Leaders }\end{array}$} & \multicolumn{2}{|c|}{$\begin{array}{l}\text { Leader's Exercise } \\
\text { of Authority }\end{array}$} & \multicolumn{2}{|c|}{$\begin{array}{c}\text { Degree of Lack of } \\
\text { Community } \\
\text { Decisions }\end{array}$} & \multicolumn{2}{|c|}{$\begin{array}{l}\text { Perception of } \\
\text { Leader's Power }\end{array}$} \\
\hline & (1) & $(2)$ & $(3)$ & (4) & $(5)$ & (6) & $(7)$ & $(8)$ & (9) & $(10)$ \\
\hline Intensity of Slavery & $\begin{array}{c}0.332^{* * *} \\
(0.116)\end{array}$ & $\begin{array}{c}0.251^{*} \\
(0.130)\end{array}$ & $\begin{array}{c}0.588^{* * *} \\
(0.128)\end{array}$ & $\begin{array}{c}0.525^{* * *} \\
(0.143)\end{array}$ & $\begin{array}{c}0.360^{* * *} \\
(0.106)\end{array}$ & $\begin{array}{l}0.297^{* *} \\
(0.123)\end{array}$ & $\begin{array}{c}0.413^{* * *} \\
(0.099)\end{array}$ & $\begin{array}{c}0.402^{* * *} \\
(0.112)\end{array}$ & $\begin{array}{c}0.322^{* * *} \\
(0.105)\end{array}$ & $\begin{array}{c}0.326^{* * *} \\
(0.117)\end{array}$ \\
\hline Log Absolute Latitude & $\begin{array}{l}-0.010 \\
(0.095)\end{array}$ & $\begin{array}{l}-0.139 \\
(0.190)\end{array}$ & $\begin{array}{c}0.107 \\
(0.075)\end{array}$ & $\begin{array}{c}0.041 \\
(0.115)\end{array}$ & $\begin{array}{l}-0.085 \\
(0.086)\end{array}$ & $\begin{array}{l}-0.098 \\
(0.167)\end{array}$ & $\begin{array}{l}-0.140^{*} \\
(0.076)\end{array}$ & $\begin{array}{l}-0.107 \\
(0.110)\end{array}$ & $\begin{array}{l}-0.008 \\
(0.085)\end{array}$ & $\begin{array}{c}0.033 \\
(0.130)\end{array}$ \\
\hline Elevation & & $\begin{array}{l}-0.000 \\
(0.000)\end{array}$ & & $\begin{array}{l}-0.000 \\
(0.000)\end{array}$ & & $\begin{array}{l}-0.000 \\
(0.000)\end{array}$ & & $\begin{array}{c}0.000 \\
(0.000)\end{array}$ & & $\begin{array}{c}0.000 \\
(0.000)\end{array}$ \\
\hline Terrain Ruggedness & & $\begin{array}{c}0.000 \\
(0.000)\end{array}$ & & $\begin{array}{c}0.000^{*} \\
(0.000)\end{array}$ & & $\begin{array}{c}0.000 \\
(0.000)\end{array}$ & & $\begin{array}{c}0.000 \\
(0.000)\end{array}$ & & $\begin{array}{l}-0.000 \\
(0.000)\end{array}$ \\
\hline River Length & & $\begin{array}{c}0.013 \\
(0.010)\end{array}$ & & $\begin{array}{l}-0.008 \\
(0.012)\end{array}$ & & $\begin{array}{c}0.006 \\
(0.009)\end{array}$ & & $\begin{array}{l}-0.002 \\
(0.006)\end{array}$ & & $\begin{array}{c}0.011 \\
(0.009)\end{array}$ \\
\hline River Density & & $\begin{array}{l}-0.045 \\
(0.053)\end{array}$ & & $\begin{array}{l}-0.004 \\
(0.035)\end{array}$ & & $\begin{array}{l}-0.023 \\
(0.035)\end{array}$ & & $\begin{array}{c}0.012 \\
(0.043)\end{array}$ & & $\begin{array}{l}-0.018 \\
(0.038)\end{array}$ \\
\hline Share Desert & & $\begin{array}{c}0.307 \\
(0.472)\end{array}$ & & $\begin{array}{c}0.268 \\
(0.627)\end{array}$ & & $\begin{array}{l}-0.578 \\
(0.513)\end{array}$ & & $\begin{array}{c}0.218 \\
(0.413)\end{array}$ & & $\begin{array}{c}0.253 \\
(0.460)\end{array}$ \\
\hline Average Temperature & & $\begin{array}{l}-0.007 \\
(0.020)\end{array}$ & & $\begin{array}{c}0.000 \\
(0.018)\end{array}$ & & $\begin{array}{c}0.013 \\
(0.018)\end{array}$ & & $\begin{array}{c}0.008 \\
(0.013)\end{array}$ & & $\begin{array}{c}0.005 \\
(0.017)\end{array}$ \\
\hline Temperature Range & & $\begin{array}{c}0.094 \\
(0.074)\end{array}$ & & $\begin{array}{c}0.082 \\
(0.068)\end{array}$ & & $\begin{array}{c}0.074 \\
(0.071)\end{array}$ & & $\begin{array}{l}-0.026 \\
(0.048)\end{array}$ & & $\begin{array}{l}-0.058 \\
(0.061)\end{array}$ \\
\hline Soil Quality (Climatic) & Yes & Yes & Yes & Yes & Yes & Yes & Yes & Yes & Yes & Yes \\
\hline $\begin{array}{l}N \\
\text { Adjusted } R^{2}\end{array}$ & $\begin{array}{c}77 \\
0.082\end{array}$ & $\begin{array}{c}77 \\
0.076\end{array}$ & $\begin{array}{c}70 \\
0.254\end{array}$ & $\begin{array}{c}70 \\
0.254\end{array}$ & $\begin{array}{c}78 \\
0.139\end{array}$ & $\begin{array}{c}78 \\
0.100\end{array}$ & $\begin{array}{c}81 \\
0.229\end{array}$ & $\begin{array}{c}81 \\
0.159\end{array}$ & $\begin{array}{c}81 \\
0.167\end{array}$ & $\begin{array}{c}81 \\
0.105\end{array}$ \\
\hline
\end{tabular}

This table presents the results of a series of OLS regression analyses, on the ethnic-group level, of measures of pre-colonial autocracy on a measure of slavery, conditional on a range of control variables at the ethnic-group level. Heteroscedasticity-consistent standard errors are reported in parentheses. *** Significant at the 1 percent level. ${ }^{* *}$ Significant at the 5 percent level. ${ }^{*}$ Significant at the 10 percent level. 
Table 10: Predicted Genetic Diversity and Autocratic Institutions

\begin{tabular}{|c|c|c|c|c|c|c|c|c|c|c|}
\hline & \multicolumn{2}{|c|}{$\begin{array}{l}\text { Degree of Absence } \\
\text { of Checks on } \\
\text { Leader's Power }\end{array}$} & \multicolumn{2}{|c|}{$\begin{array}{l}\text { Difficulty of } \\
\text { Removal of } \\
\text { Leaders }\end{array}$} & \multicolumn{2}{|c|}{$\begin{array}{l}\text { Leader's Exercise } \\
\text { of Authority }\end{array}$} & \multicolumn{2}{|c|}{$\begin{array}{c}\text { Degree of Lack of } \\
\text { Community } \\
\text { Decisions }\end{array}$} & \multicolumn{2}{|c|}{$\begin{array}{l}\text { Perception of } \\
\text { Leader's Power }\end{array}$} \\
\hline & $(1)$ & $(2)$ & $(3)$ & $(4)$ & $(5)$ & $(6)$ & $(7)$ & $(8)$ & (9) & $(10)$ \\
\hline Predicted Genetic Diversity & $\begin{array}{c}6.317^{* * *} \\
(2.101)\end{array}$ & $\begin{array}{l}5.042^{* *} \\
(2.306)\end{array}$ & $\begin{array}{c}7.374^{* * *} \\
(2.222)\end{array}$ & $\begin{array}{l}5.858^{* *} \\
(2.236)\end{array}$ & $\begin{array}{c}6.048^{* * *} \\
(1.895)\end{array}$ & $\begin{array}{c}5.489^{* * *} \\
(1.984)\end{array}$ & $\begin{array}{c}6.589^{* * *} \\
(1.514)\end{array}$ & $\begin{array}{c}6.023^{* * *} \\
(1.679)\end{array}$ & $\begin{array}{c}5.529^{* * *} \\
(1.753)\end{array}$ & $\begin{array}{l}5.504^{* *} \\
(2.094)\end{array}$ \\
\hline Log Absolute Latitude & $\begin{array}{c}0.035 \\
(0.099)\end{array}$ & $\begin{array}{l}-0.080 \\
(0.189)\end{array}$ & $\begin{array}{c}0.143 \\
(0.092)\end{array}$ & $\begin{array}{c}0.111 \\
(0.148)\end{array}$ & $\begin{array}{l}-0.053 \\
(0.091)\end{array}$ & $\begin{array}{l}-0.030 \\
(0.173)\end{array}$ & $\begin{array}{l}-0.100 \\
(0.069)\end{array}$ & $\begin{array}{c}-0.044 \\
(0.120)\end{array}$ & $\begin{array}{c}0.026 \\
(0.087)\end{array}$ & $\begin{array}{c}0.090 \\
(0.144)\end{array}$ \\
\hline Elevation & & $\begin{array}{l}-0.000 \\
(0.000)\end{array}$ & & $\begin{array}{l}-0.000 \\
(0.000)\end{array}$ & & $\begin{array}{c}-0.000 \\
(0.000)\end{array}$ & & $\begin{array}{c}0.000 \\
(0.000)\end{array}$ & & $\begin{array}{c}0.000 \\
(0.000)\end{array}$ \\
\hline Terrain Ruggedness & & $\begin{array}{l}0.000^{*} \\
(0.000)\end{array}$ & & $\begin{array}{l}0.000^{* *} \\
(0.000)\end{array}$ & & $\begin{array}{c}0.000 \\
(0.000)\end{array}$ & & $\begin{array}{c}0.000 \\
(0.000)\end{array}$ & & $\begin{array}{l}-0.000 \\
(0.000)\end{array}$ \\
\hline River Length & & $\begin{array}{c}0.013 \\
(0.009)\end{array}$ & & $\begin{array}{l}-0.000 \\
(0.010)\end{array}$ & & $\begin{array}{c}0.008 \\
(0.007)\end{array}$ & & $\begin{array}{c}0.001 \\
(0.007)\end{array}$ & & $\begin{array}{l}0.014^{*} \\
(0.007)\end{array}$ \\
\hline River Density & & $\begin{array}{l}-0.061 \\
(0.050)\end{array}$ & & $\begin{array}{l}-0.031 \\
(0.040)\end{array}$ & & $\begin{array}{l}-0.044 \\
(0.033)\end{array}$ & & $\begin{array}{l}-0.016 \\
(0.041)\end{array}$ & & $\begin{array}{l}-0.043 \\
(0.033)\end{array}$ \\
\hline Share Desert & & $\begin{array}{c}0.235 \\
(0.533)\end{array}$ & & $\begin{array}{c}0.157 \\
(0.613)\end{array}$ & & $\begin{array}{l}-0.561 \\
(0.543)\end{array}$ & & $\begin{array}{c}0.072 \\
(0.479)\end{array}$ & & $\begin{array}{c}0.125 \\
(0.473)\end{array}$ \\
\hline Average Temperature & & $\begin{array}{l}-0.003 \\
(0.020)\end{array}$ & & $\begin{array}{c}0.014 \\
(0.021)\end{array}$ & & $\begin{array}{c}0.020 \\
(0.019)\end{array}$ & & $\begin{array}{c}0.015 \\
(0.015)\end{array}$ & & $\begin{array}{c}0.011 \\
(0.017)\end{array}$ \\
\hline Temperature Range & & $\begin{array}{c}0.091 \\
(0.068)\end{array}$ & & $\begin{array}{c}0.087 \\
(0.067)\end{array}$ & & $\begin{array}{c}0.061 \\
(0.063)\end{array}$ & & $\begin{array}{l}-0.013 \\
(0.049)\end{array}$ & & $\begin{array}{l}-0.047 \\
(0.054)\end{array}$ \\
\hline Soil Quality (Climatic) & Yes & Yes & Yes & Yes & Yes & Yes & Yes & Yes & Yes & Yes \\
\hline $\begin{array}{l}N \\
\text { Adjusted } R^{2}\end{array}$ & $\begin{array}{c}78 \\
0.067\end{array}$ & $\begin{array}{c}78 \\
0.111\end{array}$ & $\begin{array}{c}71 \\
0.079\end{array}$ & $\begin{array}{c}71 \\
0.168\end{array}$ & $\begin{array}{c}79 \\
0.121\end{array}$ & $\begin{array}{c}79 \\
0.109\end{array}$ & $\begin{array}{c}82 \\
0.198\end{array}$ & $\begin{array}{c}82 \\
0.146\end{array}$ & $\begin{array}{c}82 \\
0.164\end{array}$ & $\begin{array}{c}82 \\
0.108\end{array}$ \\
\hline
\end{tabular}

This table presents the results of a series of OLS regression analyses, on the ethnic-group level, of measures of pre-colonial autocracy on predicted genetic diversity, based on the migratory distance from East Africa to the interior centroid of the homeland of the ethnicity, conditional on a range of control variables at the ethnic-group level. Heteroscedasticity-consistent standard errors are reported in parentheses. $* * *$ Significant at the 1 percent level. $* *$ Significant at the 5 percent level. * Significant at the 10 percent level. 
As reported in Table B.25, irrigation suitability is associated with some measures of autocracy across ethnic groups. Nevertheless, accounting for the potentially confounding effect of irrigation suitability does not alter the qualitative impact of population diversity on autocracy. ${ }^{23}$

Hence, the findings establish the impact of predicted population diversity on the prevalence of autocratic institutions, while indicating that this effect could have plausibly operated through the effect of population diversity on the formation of institutions as well as stratification.

\section{Roots of Autocracy in the Modern Era}

This section explores the determinants of contemporary national institutions. ${ }^{24}$ It examines the importance of the impact of population diversity on pre-colonial autocratic institutions across ethnic groups for understanding the contemporary variation in autocratic institutions across nations, via institutional persistence. Moreover, it analyzes the reduced-form relationship between population diversity and the nature of contemporary national institutions.

\subsection{Baseline Regression Specifications}

\subsubsection{Persistence of Autocracy}

In estimating the persistence of institutions from the pre-colonial to the modern era, the following empirical specification is adopted and estimated via ordinary least squares (OLS):

$$
A_{m, i}=\beta_{0}+\beta_{1} A_{p, i}+X_{i}^{\prime} \beta_{2}+C_{i}^{\prime} \beta_{3}+\varepsilon_{i},
$$

where $A_{m, i}$ is a measure of modern autocracy for country $i ; A_{p, i}$ is a measure of pre-colonial autocracy for country $i ; X_{i}$ is a vector of geographical control variables for country $i$; $C_{i}$ is a vector of continental dummies for country $i$; and $\varepsilon_{i}$ is an country-specific error term.

\subsubsection{Population Diversity and Modern Autocracy}

In estimating the effect of population diversity on contemporary institutions, the following empirical specification is adopted and estimated via OLS:

$$
A_{m, i}=\beta_{0}+\beta_{1} G_{m, i}+X_{m, i}^{\prime} \beta_{2}+H_{i}^{\prime} \beta_{3}+C_{m, i}^{\prime} \beta_{4}+\varepsilon_{i}
$$

where $G_{m, i}$ is the predicted level of ancestry-adjusted genetic diversity for country $i$ and $H_{i}$ is a vector of non-geographical control variables for country $i$.

\footnotetext{
${ }^{23}$ Unlike the significant positive interaction between population diversity and irrigation suitability reported in Tables B.9, B.8, and B.10, the interaction term here is insignificant, reflecting possibly the limited sample size.

${ }^{24}$ The overall negative association between autocratic institutions and economic development is reflected in Figure A.3 in the appendix.
} 


\subsection{Persistence of Autocracy}

The first layer of the empirical analysis of the determinants of modern institutions establishes the importance of the impact of population diversity on pre-colonial autocratic institutions across ethnic groups for the understanding of the contemporary variation in autocratic institutions across nations. In particular, it suggests that ethnic institutions that were formed in the pre-colonial era persisted over time and are associated with contemporary national institutions.

Aggregating pre-colonial ethnic institutions into pre-colonial national institutions, based on the average level of autocracy across ethnic-group homelands within each modern country, the analysis suggests that indeed pre-colonial ethnic institutions have contributed to contemporary institutions, beyond the persistent effect geographical determinants. In particular, the degree of autocratic institutions and the absence of executive constraints in the contemporary period are positively and significantly associated with the degree of autocratic institutions in the pre-colonial era, accounting for potentially confounding effects of geographical characteristics and population diversity.

The presence of autocratic institutions in the pre-colonial era is captured by the degree of absence of checks on leader's power, as reported by the Standard Cross Cultural Survey, whereas the degree of contemporary autocratic institutions is captured by the corresponding indexes of "Constraints on the Executive" and "Autocracy" as reported by the Polity IV Project dataset.

In view of the cross continental migration in the post-1500 period and its potential effects on cross continental diffusion of institutions as well as on changes in genetic diversity in the new world, the analysis is restricted initially to the sample of Old World countries in order to properly assess the presence of institutional persistence, and the role of geographical factors and population diversity in this persistence.

Table 11 establishes the presence of institutional persistence in the sample of Old World countries. Column 1 establishes that, unconditionally, the pre-colonial degree of absence of checks on leader's power is negatively and highly significantly associated with the executive constraints in the modern period. Column 2 suggests that the association established in column 1 is partly governed by geographical factors and their persistence over time, as reflected by the drop in the point estimate of past autocracy on modern autocracy. Nevertheless, institutional persistence remains significant at the $10 \%$ level. Furthermore, column 3 suggests that predicted population diversity has a significant effect on executive constraints in the modern period, and that the association established in column 2 is partly governed by population diversity, as reflected by the additional drop in the point estimate of past autocracy on modern autocracy. Nevertheless, institutional persistence remains significant at the $10 \%$ level.

Similarly, column 4 establishes a highly significant negative unconditional association between the pre-colonial degree of absence of checks on leader's power and the index of autocracy for the modern period. Moreover, column 5 suggests that the association established in column 4 is partly governed by geographical factors and their persistence over time, as reflected by the drop in the point

estimate of past autocracy on modern autocracy. Nevertheless, institutional persistence remains significant at the $1 \%$ level. Furthermore, column 6 suggests that predicted population diversity 
Table 11: Persistence of Autocracy

\begin{tabular}{|c|c|c|c|c|c|c|}
\hline & \multicolumn{3}{|c|}{$\begin{array}{c}\text { Executive } \\
\text { Constraints }\end{array}$} & \multicolumn{3}{|c|}{ Autocracy } \\
\hline & $(1)$ & $(2)$ & $(3)$ & $(4)$ & $(5)$ & $(6)$ \\
\hline Degree of Absence of Checks on Leader's Power & $\begin{array}{c}-0.206^{* * *} \\
(0.052)\end{array}$ & $\begin{array}{l}-0.110^{*} \\
(0.057)\end{array}$ & $\begin{array}{c}-0.098^{*} \\
(0.057)\end{array}$ & $\begin{array}{c}0.553^{* * *} \\
(0.111)\end{array}$ & $\begin{array}{l}0.395^{* *} \\
(0.148)\end{array}$ & $\begin{array}{l}0.360^{* *} \\
(0.153)\end{array}$ \\
\hline Predicted Genetic Diversity & & & $\begin{array}{c}-2.231^{* *} \\
(1.055)\end{array}$ & & & $\begin{array}{l}6.609^{* *} \\
(2.597)\end{array}$ \\
\hline Log Absolute Latitude & & $\begin{array}{l}-0.075 \\
(0.050)\end{array}$ & $\begin{array}{c}-0.090^{*} \\
(0.050)\end{array}$ & & $\begin{array}{c}0.088 \\
(0.134)\end{array}$ & $\begin{array}{c}0.133 \\
(0.121)\end{array}$ \\
\hline Soil Fertility & & $\begin{array}{c}0.322 \\
(0.416)\end{array}$ & $\begin{array}{c}0.225 \\
(0.414)\end{array}$ & & $\begin{array}{l}-1.122 \\
(1.071)\end{array}$ & $\begin{array}{l}-0.836 \\
(0.993)\end{array}$ \\
\hline Roughness & & $\begin{array}{c}0.023 \\
(0.499)\end{array}$ & $\begin{array}{c}-0.149 \\
(0.516)\end{array}$ & & $\begin{array}{c}0.378 \\
(1.351)\end{array}$ & $\begin{array}{c}0.889 \\
(1.377)\end{array}$ \\
\hline Elevation & & $\begin{array}{l}-0.207^{*} \\
(0.106)\end{array}$ & $\begin{array}{l}-0.172 \\
(0.115)\end{array}$ & & $\begin{array}{c}0.503 \\
(0.319)\end{array}$ & $\begin{array}{c}0.401 \\
(0.349)\end{array}$ \\
\hline Average Distance to Nearest Waterway & & $\begin{array}{c}-0.301^{* *} \\
(0.113)\end{array}$ & $\begin{array}{c}-0.246^{* *} \\
(0.117)\end{array}$ & & $\begin{array}{c}0.317 \\
(0.289)\end{array}$ & $\begin{array}{c}0.155 \\
(0.316)\end{array}$ \\
\hline Percentage of Arable Land & & $\begin{array}{c}0.004 \\
(0.004)\end{array}$ & $\begin{array}{c}0.005 \\
(0.004)\end{array}$ & & $\begin{array}{l}-0.002 \\
(0.010)\end{array}$ & $\begin{array}{l}-0.006 \\
(0.010)\end{array}$ \\
\hline Temperature & & $\begin{array}{c}-0.024^{* * *} \\
(0.008)\end{array}$ & $\begin{array}{c}-0.019^{* *} \\
(0.008)\end{array}$ & & $\begin{array}{c}0.027 \\
(0.018)\end{array}$ & $\begin{array}{c}0.012 \\
(0.018)\end{array}$ \\
\hline Colony & & $\begin{array}{c}0.156 \\
(0.127)\end{array}$ & $\begin{array}{c}0.069 \\
(0.142)\end{array}$ & & $\begin{array}{l}-0.304 \\
(0.252)\end{array}$ & $\begin{array}{l}-0.047 \\
(0.285)\end{array}$ \\
\hline$N$ & 42 & 42 & 42 & 42 & 42 & 42 \\
\hline Adjusted $R^{2}$ & 0.191 & 0.387 & 0.418 & 0.272 & 0.259 & 0.320 \\
\hline
\end{tabular}

This table presents the results of a series of OLS regression analyses, on the contemporary country level, of measures of contemporary autocracy on measures of pre-colonial autocracy on the sample of Old-World countries. Specifications marked with "Continental FE" accounts for sub-Saharan Africa, Latin America, and continental fixed effects. Heteroscedasticity-consistent standard errors are reported in parentheses. *** Significant at the 1 percent level. ** Significant at the 5 percent level. * Significant at the 10 percent level. 
has a significant effect on executive constraints in the modern period, and that the association established in column 5 is partly governed by population diversity, as reflected by the additional drop in the point estimate of past autocracy on modern autocracy. Nevertheless, institutional persistence remains significant at the $5 \%$ level. ${ }^{25}$ Moreover, as reported in Table B.27 in the Appendix, institutional persistence is present in the global sample as well. ${ }^{26}$

\subsection{Contemporary Population Diversity and Modern Autocracy}

The second layer of the empirical analysis of the determinants of modern institutions explores the contribution of modern population diversity to contemporary autocratic national institutions. It examines whether population diversity at the national level, as captured by predicted population diversity, has a significant effect on the degree of autocracy and the absence of executive constraints across countries, accounting for a large number of confounding geographical characteristics, regional fixed effects, colonial history (i.e., duration and colonizer nation), legal origins, pre-colonial development and the degree of ethnolinguistic fractionalization and its potential geographical origins.

The country-level analysis employs the measure of genetic diversity, as constructed by Ashraf and Galor (2013), accounting for three important elements of population diversity with a national population: the proportional representation of each ethnic group within the country, the expected heterozygosity within each subnational group, as well as the diversity that arises from the genetic distances between the pre-colonial ancestral populations.

\subsubsection{Population Diversity and Constraint on the Executive}

This subsection establishes that consistent with the proposed hypothesis population diversity at the national level has a highly significant adverse effect on the degree of executive constraints, accounting for a large number of confounding factors.

As reported in Table 12, column 1 establishes based on data from 145 countries that, unconditionally, the level of predicted genetic diversity within a country in the modern era has a highly significant negative effect on the constraint on the chief executive. ${ }^{27}$ The estimated effect indicates that a 1 percentage point increase in predicted genetic diversity generates a 4.1 percent decrease in the average level of the "Constraint on the Chief Executive" over the period 1994-2013. ${ }^{28}$ Columns

\footnotetext{
${ }^{25}$ As established in Table B.28 in the appendix, these findings are robust to using indigenous autocracy, rather than the degree of absence of checks on leader's power, as a measure of autocracy across ethnic-group homelands within modern country borders. Moreover, as shown in Table B.29 in the appendix, using a measure of indigenous democracy derived from an alternative aggregation procedure from the ethnic group level to the country level, based on Giuliano and Nunn (2013), produces similar results on a larger set of countries.

${ }^{26}$ The effect of population diversity on institutional persistence in this global sample is harder to assess due to the fact that population diversity has changed in some countries over this time period, and the measures of population diversity either in the pre-colonial period or in the modern period do not fully capture the dynamic of this variable in the time period in between these two time points.

${ }^{27}$ It should be noted that the effect of predicted population diversity on autocracy in the modern era is not quadratic. In particular, if predicted genetic diversity squared is included to the baseline specifications, the estimated coefficient of this square term is insignificant in all specifications.

${ }^{28}$ The examination of the effect of genetic diversity on autocracy in earlier periods covered by the Polity IV data set is not feasible since the data is available only for a small and selected group of countries whose institutions
} 
2-4 establish that the effect remains highly significant once additional confounding geographical characteristics are accounted for. In addition, column 5 indicates that the negative effect of predicted population diversity remains highly significant while accounting for continental fixed effects, capturing unobserved heterogeneity across continents. Reassuringly, as reported in columns 6 and 7 , the effect of genetic diversity on contemporary executive constraints is unaffected by colonial history and legal origins fixed effects. This partial association between constraint on the executive and population diversity, as derived in column 7, is plotted in Figure A.4.

Furthermore, Table B.30 in the appendix establishes that the findings in Table 12 are robust to focusing on constraint on the executive in 2013. Moreover, accounting for the potentially confounding effect of irrigation suitability does not alter the qualitative impact of population diversity on autocracy (Table B.31). ${ }^{29}$ In addition, the findings are robust to the use of additional geographical controls, such as the percentage of land near a waterway (Table B.32), inequality of land suitability (Table B.33), and percentages of population living in various climate zones (Table B.34). Furthermore, they are robust to the inclusion of additional measures of colonial history, such as colonizer nation (Table B.35) and colonial duration (Table B.36). Moreover, the findings are robust to the inclusion of arguably endogenous controls, such as income per capita (Table B.37), years of schooling (Table B.38), population density in 1500 (Table B.39), and social infrastructure (Table B.40). Finally, the use of ethnolinguistic fractionalization as an alternative measure of population diversity suggests that, while fractionalization has no effect on executive constraints, the effect of genetic diversity remains nearly intact (Table B.41).

\subsubsection{Population Diversity and Executive Constraints: IV Analysis}

In light of the potential effect on autocracy on population diversity via the cross-continental migration in the post-1500 era, the empirical analysis exploits an instrumental variable strategy to identify the causal effect of population diversity on constraints on the executives. In view of the negative effect of migratory distance from the cradle of humankind in East Africa to various settlements across the globe on population diversity, migratory distance from Africa is exploited as an instrumental variable for population diversity.

The causal effect of population diversity on the constraint on the executive is established in Table 13, which presents the estimation results from 2SLS regression analyses instrumenting population diversity by the migratory distance from East Africa. Column 1 establishes that the level of population diversity has a highly significant effect on the constraint on the chief executive in 19942013. Columns 2-4 establish that the effect remains highly significant once additional confounding geographical characteristics are accounted for. In addition, column 5 indicates that the negative

were sufficiently growth promoting so as to be included in the sample. In particular, those countries are generally developed countries with less autocratic institutions today. Furthermore, the analysis based on the Ethnographic Atlas provides captures some of this period since the description of ethnic groups in these sample is primarily based on their characteristics around the turn to the 20th century.

${ }^{29}$ Unlike the significant positive interaction between population diversity and irrigation suitability reported in Tables B.9, B.8, and B.10, the interaction here is insignificant, reflecting possibly the limited sample size. 
Table 12: Predicted Population Diversity and Constraint on the Executive (1994-2013)

\begin{tabular}{|c|c|c|c|c|c|c|c|}
\hline & \multicolumn{7}{|c|}{ Log Constraint on Chief Executive } \\
\hline & (1) & $(2)$ & $(3)$ & (4) & $(5)$ & (6) & (7) \\
\hline Predicted Genetic Diversity & $\begin{array}{c}-4.050^{* * *} \\
(0.825)\end{array}$ & $\begin{array}{c}-4.094^{* * *} \\
(0.836)\end{array}$ & $\begin{array}{c}-2.814^{* * *} \\
(0.888)\end{array}$ & $\begin{array}{c}-2.804^{* * *} \\
(0.867)\end{array}$ & $\begin{array}{c}-3.280^{* *} \\
(1.435)\end{array}$ & $\begin{array}{c}-3.356^{* *} \\
(1.350)\end{array}$ & $\begin{array}{c}-3.472^{* *} \\
(1.342)\end{array}$ \\
\hline Log Absolute Latitude & & $\begin{array}{c}0.094^{* * *} \\
(0.028)\end{array}$ & $\begin{array}{c}0.055^{*} \\
(0.030)\end{array}$ & $\begin{array}{l}-0.059 \\
(0.042)\end{array}$ & $\begin{array}{c}0.022 \\
(0.042)\end{array}$ & $\begin{array}{c}0.018 \\
(0.038)\end{array}$ & $\begin{array}{c}0.026 \\
(0.037)\end{array}$ \\
\hline Soil Fertility & & & $\begin{array}{l}0.500^{* *} \\
(0.242)\end{array}$ & $\begin{array}{l}0.415^{*} \\
(0.230)\end{array}$ & $\begin{array}{c}0.166 \\
(0.208)\end{array}$ & $\begin{array}{c}0.310 \\
(0.202)\end{array}$ & $\begin{array}{c}0.306 \\
(0.203)\end{array}$ \\
\hline Roughness & & & $\begin{array}{c}0.135 \\
(0.316)\end{array}$ & $\begin{array}{c}0.038 \\
(0.326)\end{array}$ & $\begin{array}{c}0.341 \\
(0.324)\end{array}$ & $\begin{array}{c}0.383 \\
(0.297)\end{array}$ & $\begin{array}{c}0.464 \\
(0.290)\end{array}$ \\
\hline Elevation & & & $\begin{array}{l}-0.065 \\
(0.095)\end{array}$ & $\begin{array}{l}-0.103 \\
(0.095)\end{array}$ & $\begin{array}{l}-0.008 \\
(0.110)\end{array}$ & $\begin{array}{l}-0.062 \\
(0.103)\end{array}$ & $\begin{array}{l}-0.058 \\
(0.096)\end{array}$ \\
\hline Average Distance to Nearest Waterway & & & $\begin{array}{l}-0.170^{*} \\
(0.094)\end{array}$ & $\begin{array}{c}-0.248^{* * *} \\
(0.090)\end{array}$ & $\begin{array}{c}-0.161^{*} \\
(0.085)\end{array}$ & $\begin{array}{l}-0.070 \\
(0.091)\end{array}$ & $\begin{array}{l}-0.050 \\
(0.092)\end{array}$ \\
\hline Percentage of Arable Land & & & $\begin{array}{c}0.002 \\
(0.002)\end{array}$ & $\begin{array}{c}0.001 \\
(0.002)\end{array}$ & $\begin{array}{c}0.002 \\
(0.003)\end{array}$ & $\begin{array}{c}0.002 \\
(0.002)\end{array}$ & $\begin{array}{c}0.002 \\
(0.002)\end{array}$ \\
\hline Temperature & & & & $\begin{array}{c}-0.020^{* * *} \\
(0.005)\end{array}$ & $\begin{array}{l}-0.007 \\
(0.009)\end{array}$ & $\begin{array}{l}-0.009 \\
(0.010)\end{array}$ & $\begin{array}{l}-0.015 \\
(0.010)\end{array}$ \\
\hline Colony & & & & & & & $\begin{array}{c}0.264^{*} \\
(0.147)\end{array}$ \\
\hline Continental FE & No & No & No & No & Yes & Yes & Yes \\
\hline Legal Origin FE & No & No & No & No & No & Yes & Yes \\
\hline$N$ & 145 & 145 & 145 & 145 & 145 & 145 & 145 \\
\hline Adjusted $R^{2}$ & 0.068 & 0.108 & 0.221 & 0.292 & 0.405 & 0.456 & 0.472 \\
\hline
\end{tabular}

This table presents the results of a series of OLS regression analyses, on the contemporary country level, of a measure of contemporary autocracy on predicted genetic diversity, conditional on a range of control variables. Specifications marked with "Continental FE" accounts for sub-Saharan Africa, Latin America, and continental fixed effects. Heteroscedasticity-consistent standard errors are reported in parentheses. ${ }^{* * *}$ Significant at the 1 percent level. ${ }^{* *}$ Significant at the 5 percent level. ${ }^{*}$ Significant at the 10 percent level. 
effect of predicted population diversity remains highly significant while accounting for continental fixed effects, capturing unobserved heterogeneity across continents. Reassuringly, as reported in columns 6 and 7, the effect of genetic diversity on contemporary executive constraints is unaffected by colonial history and legal origins fixed effects.

\subsubsection{Population Diversity and Autocracy}

This subsection establishes that consistent with the proposed hypothesis population diversity at the national level has a highly significant adverse effect on the index of autocracy, accounting for a large number of confounding geographical characteristics, regional fixed effects, colonial history, legal origins, pre-colonial development and the degree of ethnolinguistic fractionalization and its potential geographical origins. Moreover, the effect remains nearly intact if one accounts for arguably endogenous controls such as income per capita and education.

As reported in Table 14, column 1 establishes based on data from 145 countries that, unconditionally, the level of predicted genetic diversity within a country in the modern era has a highly significant negative effect on the level of autocracy. The estimated effect indicates that a 1 percentage point increase in predicted genetic diversity generates an 8.7 percent increase in the average level of the autocracy measure over the period 1994-2013. Columns 2-4 establish that the effect remains highly significant once additional confounding geographical characteristics are accounted for. In addition, column 5 indicates that the negative effect of predicted population diversity remains highly significant while accounting for continental fixed effects, capturing unobserved heterogeneity across continents. Reassuringly, as reported in columns 6 and 7, the effect of genetic diversity on contemporary autocracy is unaffected by colonial history and legal origins fixed effects. This partial association between constraint on the executive and population diversity, as derived in column 7 , is plotted in Figure A.5.

Furthermore, Table B.42 in the appendix establishes that the findings in Table 14 are robust to focusing on constraint on the executive in 2013. Moreover, accounting for the potentially confounding effect of irrigation suitability does not alter the qualitative impact of population diversity on autocracy (Table B.43). ${ }^{30}$ In addition, the findings are robust to the use of additional geographical controls, such as the percentage of land near a waterway (Table B.44), inequality of land suitability (Table B.45), and percentages of population living in various climate zones (Table B.46). Furthermore, they are robust to the inclusion of additional measures of colonial history, such as colonizer nation (Table B.47) and colonial duration (Table B.48). Moreover, the findings are robust to the inclusion of arguably endogenous controls, such as income per capita (Table B.49), years of schooling (Table B.50), population density in 1500 (Table B.51), and social infrastructure (Table B.52). Finally, the use of ethnolinguistic fractionalization as an alternative measure of population

\footnotetext{
${ }^{30}$ Unlike the significant positive interaction between population diversity and irrigation suitability reported in Tables B.9, B.8, and B.10, the interaction here is insignificant, reflecting possibly the limited sample size.
} 
Table 13: Predicted Genetic Diversity and Constraint on the Executive (1994-2013) — Instrumental Variable Analysis

\begin{tabular}{|c|c|c|c|c|c|c|c|}
\hline & \multicolumn{7}{|c|}{ Log Constraint on Chief Executive } \\
\hline & (1) & $(2)$ & (3) & (4) & $(5)$ & (6) & $(7)$ \\
\hline Predicted Genetic Diversity & $\begin{array}{c}-6.305^{* * *} \\
(1.209)\end{array}$ & $\begin{array}{c}-6.586^{* * *} \\
(1.196)\end{array}$ & $\begin{array}{c}-5.376^{* * *} \\
(1.427)\end{array}$ & $\begin{array}{c}-5.401^{* * *} \\
(1.320)\end{array}$ & $\begin{array}{c}-7.169^{* * *} \\
(2.396)\end{array}$ & $\begin{array}{c}-6.964^{* * *} \\
(2.208)\end{array}$ & $\begin{array}{c}-7.059^{* * *} \\
(2.153)\end{array}$ \\
\hline Log Absolute Latitude & & $\begin{array}{c}0.095^{* * *} \\
(0.029)\end{array}$ & $\begin{array}{c}0.057^{*} \\
(0.030)\end{array}$ & $\begin{array}{l}-0.057 \\
(0.041)\end{array}$ & $\begin{array}{c}0.042 \\
(0.043)\end{array}$ & $\begin{array}{c}0.036 \\
(0.037)\end{array}$ & $\begin{array}{c}0.044 \\
(0.037)\end{array}$ \\
\hline Soil Fertility & & & $\begin{array}{l}0.419^{*} \\
(0.249)\end{array}$ & $\begin{array}{l}0.333 \\
(0.238)\end{array}$ & $\begin{array}{c}0.066 \\
(0.227)\end{array}$ & $\begin{array}{c}0.216 \\
(0.219)\end{array}$ & $\begin{array}{c}0.212 \\
(0.221)\end{array}$ \\
\hline Roughness & & & $\begin{array}{c}0.005 \\
(0.308)\end{array}$ & $\begin{array}{l}-0.093 \\
(0.318)\end{array}$ & $\begin{array}{c}0.480 \\
(0.333)\end{array}$ & $\begin{array}{l}0.519^{*} \\
(0.305)\end{array}$ & $\begin{array}{l}0.603^{* *} \\
(0.298)\end{array}$ \\
\hline Elevation & & & $\begin{array}{l}-0.036 \\
(0.095)\end{array}$ & $\begin{array}{l}-0.073 \\
(0.096)\end{array}$ & $\begin{array}{l}-0.026 \\
(0.107)\end{array}$ & $\begin{array}{l}-0.086 \\
(0.101)\end{array}$ & $\begin{array}{l}-0.082 \\
(0.095)\end{array}$ \\
\hline Average Distance to Nearest Waterway & & & $\begin{array}{l}-0.150 \\
(0.093)\end{array}$ & $\begin{array}{c}-0.228^{* *} \\
(0.091)\end{array}$ & $\begin{array}{c}-0.137^{*} \\
(0.083)\end{array}$ & $\begin{array}{l}-0.050 \\
(0.088)\end{array}$ & $\begin{array}{l}-0.029 \\
(0.090)\end{array}$ \\
\hline Percentage of Arable Land & & & $\begin{array}{c}0.003 \\
(0.003)\end{array}$ & $\begin{array}{c}0.002 \\
(0.003)\end{array}$ & $\begin{array}{c}0.003 \\
(0.003)\end{array}$ & $\begin{array}{c}0.003 \\
(0.003)\end{array}$ & $\begin{array}{c}0.003 \\
(0.002)\end{array}$ \\
\hline Temperature & & & & $\begin{array}{c}-0.020^{* * *} \\
(0.005)\end{array}$ & $\begin{array}{l}-0.007 \\
(0.009)\end{array}$ & $\begin{array}{l}-0.011 \\
(0.010)\end{array}$ & $\begin{array}{l}-0.016^{*} \\
(0.009)\end{array}$ \\
\hline Colony & & & & & & & $\begin{array}{l}0.277^{* *} \\
(0.133)\end{array}$ \\
\hline Continental FE & No & $\mathrm{No}$ & $\mathrm{No}$ & No & Yes & Yes & Yes \\
\hline Legal Origin FE & No & No & No & No & No & Yes & Yes \\
\hline$N$ & 145 & 145 & 145 & 145 & 145 & 145 & 145 \\
\hline $1^{\text {st }}$ Stage $F$-statistic (K-P) & 64.417 & 63.948 & 53.813 & 53.402 & 62.574 & 57.369 & 56.612 \\
\hline
\end{tabular}

This table presents the results of a series of 2SLS regression analyses, on the contemporary country level, of a measure of contemporary autocracy on predicted genetic diversity, instrumented by the migratory distance from East Africa to the country, conditional on a range of control variables. Specifications marked with "Continental FE" accounts for sub-Saharan Africa, Latin America, and continental fixed effects. Heteroscedasticity-consistent standard errors are reported in parentheses. ${ }^{* * *}$ Significant at the 1 percent level. $* *$ Significant at the 5 percent level. $*$ Significant at the 10 percent level. 
Table 14: Predicted Population Diversity and Autocracy (1994-2013)

\begin{tabular}{|c|c|c|c|c|c|c|c|}
\hline & \multicolumn{7}{|c|}{ Log Autocracy } \\
\hline & $(1)$ & $(2)$ & $(3)$ & $(4)$ & $(5)$ & (6) & $(7)$ \\
\hline Predicted Genetic Diversity & $\begin{array}{c}8.745^{* * *} \\
(1.826)\end{array}$ & $\begin{array}{c}8.814^{* * *} \\
(1.862)\end{array}$ & $\begin{array}{c}6.173^{* * *} \\
(2.039)\end{array}$ & $\begin{array}{c}6.153^{* * *} \\
(2.016)\end{array}$ & $\begin{array}{l}6.844^{* *} \\
(3.035)\end{array}$ & $\begin{array}{l}6.979^{* *} \\
(2.693)\end{array}$ & $\begin{array}{c}7.112^{* * *} \\
(2.699)\end{array}$ \\
\hline Log Absolute Latitude & & $\begin{array}{c}-0.149^{* * *} \\
(0.051)\end{array}$ & $\begin{array}{l}-0.061 \\
(0.055)\end{array}$ & $\begin{array}{l}0.160^{* *} \\
(0.078)\end{array}$ & $\begin{array}{l}-0.048 \\
(0.081)\end{array}$ & $\begin{array}{l}-0.036 \\
(0.073)\end{array}$ & $\begin{array}{l}-0.045 \\
(0.074)\end{array}$ \\
\hline Soil Fertility & & & $\begin{array}{c}-1.281^{* * *} \\
(0.482)\end{array}$ & $\begin{array}{c}-1.117^{* *} \\
(0.461)\end{array}$ & $\begin{array}{l}-0.422 \\
(0.382)\end{array}$ & $\begin{array}{c}-0.761^{* *} \\
(0.379)\end{array}$ & $\begin{array}{c}-0.756^{* *} \\
(0.380)\end{array}$ \\
\hline Roughness & & & $\begin{array}{l}-0.244 \\
(0.705)\end{array}$ & $\begin{array}{l}-0.056 \\
(0.722)\end{array}$ & $\begin{array}{l}-0.844 \\
(0.680)\end{array}$ & $\begin{array}{l}-0.875 \\
(0.603)\end{array}$ & $\begin{array}{l}-0.968 \\
(0.591)\end{array}$ \\
\hline Elevation & & & $\begin{array}{c}0.306 \\
(0.195)\end{array}$ & $\begin{array}{c}0.380^{*} \\
(0.198)\end{array}$ & $\begin{array}{c}0.188 \\
(0.201)\end{array}$ & $\begin{array}{c}0.303^{*} \\
(0.182)\end{array}$ & $\begin{array}{c}0.299^{*} \\
(0.174)\end{array}$ \\
\hline Average Distance to Nearest Waterway & & & $\begin{array}{c}0.203 \\
(0.185)\end{array}$ & $\begin{array}{c}0.355^{* *} \\
(0.177)\end{array}$ & $\begin{array}{c}0.154 \\
(0.149)\end{array}$ & $\begin{array}{c}-0.051 \\
(0.162)\end{array}$ & $\begin{array}{l}-0.075 \\
(0.164)\end{array}$ \\
\hline Percentage of Arable Land & & & $\begin{array}{l}-0.001 \\
(0.005)\end{array}$ & $\begin{array}{c}0.001 \\
(0.005)\end{array}$ & $\begin{array}{l}-0.003 \\
(0.005)\end{array}$ & $\begin{array}{c}-0.003 \\
(0.005)\end{array}$ & $\begin{array}{c}-0.003 \\
(0.005)\end{array}$ \\
\hline Temperature & & & & $\begin{array}{c}0.039^{* * *} \\
(0.011)\end{array}$ & $\begin{array}{c}0.013 \\
(0.017)\end{array}$ & $\begin{array}{c}0.021 \\
(0.017)\end{array}$ & $\begin{array}{c}0.027 \\
(0.018)\end{array}$ \\
\hline Colony & & & & & & & $\begin{array}{c}-0.304 \\
(0.244)\end{array}$ \\
\hline Continental FE & No & No & No & No & Yes & Yes & Yes \\
\hline Legal Origin FE & No & No & No & No & No & Yes & Yes \\
\hline$N$ & 145 & 145 & 145 & 145 & 145 & 145 & 145 \\
\hline Adjusted $R^{2}$ & 0.074 & 0.095 & 0.208 & 0.269 & 0.440 & 0.507 & 0.509 \\
\hline
\end{tabular}

This table presents the results of a series of OLS regression analyses, on the contemporary country level, of a measure of contemporary autocracy on predicted genetic diversity, conditional on a range of control variables. Specifications marked with "Continental FE" accounts for sub-Saharan Africa, Latin America, and continental fixed effects. Heteroscedasticity-consistent standard errors are reported in parentheses. *** Significant at the 1 percent level. ** Significant at the 5 percent level. * Significant at the 10 percent level. 
Table 15: Predicted Genetic Diversity and Autocracy (1994-2013) — Instrumental Variable Analysis

\begin{tabular}{|c|c|c|c|c|c|c|c|}
\hline & \multicolumn{7}{|c|}{ Log Autocracy } \\
\hline & (1) & $(2)$ & $(3)$ & $(4)$ & $(5)$ & (6) & $(7)$ \\
\hline Predicted Genetic Diversity & $\begin{array}{c}14.510^{* * *} \\
(2.614)\end{array}$ & $\begin{array}{c}14.958^{* * *} \\
(2.609)\end{array}$ & $\begin{array}{c}12.215^{* * *} \\
(3.206)\end{array}$ & $\begin{array}{c}12.262^{* * *} \\
(3.036)\end{array}$ & $\begin{array}{c}11.767^{* *} \\
(5.087)\end{array}$ & $\begin{array}{c}11.258^{* *} \\
(4.382)\end{array}$ & $\begin{array}{c}11.368^{* * *} \\
(4.334)\end{array}$ \\
\hline Log Absolute Latitude & & $\begin{array}{c}-0.151^{* * *} \\
(0.053)\end{array}$ & $\begin{array}{l}-0.066 \\
(0.053)\end{array}$ & $\begin{array}{l}0.154^{* *} \\
(0.070)\end{array}$ & $\begin{array}{c}-0.074 \\
(0.077)\end{array}$ & $\begin{array}{l}-0.057 \\
(0.067)\end{array}$ & $\begin{array}{l}-0.066 \\
(0.067)\end{array}$ \\
\hline Soil Fertility & & & $\begin{array}{c}-1.090^{* *} \\
(0.494)\end{array}$ & $\begin{array}{l}-0.924^{*} \\
(0.476)\end{array}$ & $\begin{array}{c}-0.294 \\
(0.396)\end{array}$ & $\begin{array}{l}-0.649^{*} \\
(0.388)\end{array}$ & $\begin{array}{l}-0.645^{*} \\
(0.390)\end{array}$ \\
\hline Roughness & & & $\begin{array}{c}0.063 \\
(0.706)\end{array}$ & $\begin{array}{c}0.254 \\
(0.723)\end{array}$ & $\begin{array}{l}-1.021 \\
(0.655)\end{array}$ & $\begin{array}{c}-1.037^{*} \\
(0.580)\end{array}$ & $\begin{array}{c}-1.134^{* *} \\
(0.569)\end{array}$ \\
\hline Elevation & & & $\begin{array}{c}0.237 \\
(0.198)\end{array}$ & $\begin{array}{c}0.310 \\
(0.202)\end{array}$ & $\begin{array}{c}0.211 \\
(0.192)\end{array}$ & $\begin{array}{c}0.332^{*} \\
(0.175)\end{array}$ & $\begin{array}{c}0.327^{*} \\
(0.167)\end{array}$ \\
\hline Average Distance to Nearest Waterway & & & $\begin{array}{c}0.156 \\
(0.184)\end{array}$ & $\begin{array}{l}0.307^{*} \\
(0.178)\end{array}$ & $\begin{array}{c}0.124 \\
(0.145)\end{array}$ & $\begin{array}{c}-0.074 \\
(0.156)\end{array}$ & $\begin{array}{l}-0.099 \\
(0.159)\end{array}$ \\
\hline Percentage of Arable Land & & & $\begin{array}{l}-0.004 \\
(0.005)\end{array}$ & $\begin{array}{l}-0.002 \\
(0.005)\end{array}$ & $\begin{array}{l}-0.005 \\
(0.005)\end{array}$ & $\begin{array}{l}-0.005 \\
(0.004)\end{array}$ & $\begin{array}{l}-0.005 \\
(0.004)\end{array}$ \\
\hline Temperature & & & & $\begin{array}{c}0.039^{* * *} \\
(0.010)\end{array}$ & $\begin{array}{c}0.013 \\
(0.016)\end{array}$ & $\begin{array}{c}0.022 \\
(0.016)\end{array}$ & $\begin{array}{c}0.029^{*} \\
(0.016)\end{array}$ \\
\hline Colony & & & & & & & $\begin{array}{l}-0.319 \\
(0.224)\end{array}$ \\
\hline Continental FE & No & No & No & No & Yes & Yes & Yes \\
\hline Legal Origin FE & No & No & No & No & No & Yes & Yes \\
\hline$N$ & 145 & 145 & 145 & 145 & 145 & 145 & 145 \\
\hline $1^{\text {st }}$ Stage $F$-statistic $(\mathrm{K}-\mathrm{P})$ & 64.417 & 63.948 & 53.813 & 53.402 & 62.574 & 57.369 & 56.612 \\
\hline
\end{tabular}

This table presents the results of a series of 2SLS regression analyses, on the contemporary country level, of a measure of contemporary autocracy on predicted genetic diversity, instrumented by the migratory distance from East Africa to the country, conditional on a range of control variables. Specifications marked with "Continental FE" accounts for sub-Saharan Africa, Latin America, and continental fixed effects. Heteroscedasticity-consistent standard errors are reported in parentheses. *** Significant at the 1 percent level. ** Significant at the 5 percent level. * Significant at the 10 percent level. 
diversity suggests that, while fractionalization has no effect on executive constraints, the effect of genetic diversity remains nearly intact (Table B.53). ${ }^{31}$

\subsubsection{Population Diversity and Autocracy: IV Analysis}

The causal effect of population diversity on autocracy is established in Table 15, which presents the estimation results from 2SLS regression analyses instrumenting predicted genetic diversity by the migratory distance from East Africa. Column 1 establishes that the level of predicted genetic diversity has a highly significant effect on autocracy in 1994-2013. Columns 2-4 establish that the effect remains highly significant once additional confounding geographical characteristics are accounted for. In addition, column 5 indicates that the negative effect of predicted population diversity remains highly significant while accounting for continental fixed effects, capturing unobserved heterogeneity across continents. Reassuringly, as reported in columns 6 and 7, the effect of genetic diversity on contemporary autocracy is unaffected by colonial history and legal origins fixed effects.

Thus, the second layer of the empirical analysis of the determinants of contemporary institutions suggests that the spatial distribution of population diversity across the globe has also contributed to contemporary variation in the degree of autocracy across countries. This reduced-form effect of population diversity on the prevalence of contemporary autocratic institutions across nations may reflect either persistence of institutions from the pre-colonial to the modern era, as established in the first layer of the analysis, or a direct effect of population diversity on contemporary autocratic institutions, capturing the effect of diversity on the demand for institutions as well as for the scope for domination.

\section{Conclusion}

This research explores the origins of the variation in the prevalence and nature of political institutions across the globe. It advances the hypothesis and establishes empirically that diversity across human societies, as determined in the course of the exodus of Homo sapiens from Africa tens of thousands of years ago, contributed to the formation of autocratic institutions across societies. The study suggests that while population diversity has amplified the beneficial effects of institutions in mitigating the adverse effects of non-cohesiveness on productivity, the contribution of diversity to the range of cognitive and physical traits has fostered the scope for domination, leading to the formation and persistence of institutions of the autocratic type.

The analysis suggests that diversity contributed to the emergence of autocratic pre-colonial institutions. Moreover, the findings indicate that the impact of diversity on these institutions has plausibly operated through its dual effect on the formation of institutions as well as class stratification. Furthermore, reflecting the persistence of institutional, cultural, and human characteristics,

\footnotetext{
${ }^{31}$ While the positive effect of fractionalization on autocracy is significant in the absence of geographical controls, consistent with Aghion et al. (2004), once geographical controls are introduced only genetic diversity remains significant.
} 
the study suggests that the spatial distribution of population diversity across the globe has also contributed to contemporary variation in the degree of autocracy across countries.

\section{References}

Acemoglu, D., S. Johnson, And J. A. Robinson (2001): "The Colonial Origins of Comparative Development: An Empirical Investigation," American Economic Review, 91, 1369-1401.

Acemoglu, D. And J. A. Robinson (2012): Why Nations Fail: The Origins of Power, Prosperity and Poverty, New York: Crown, 1st ed.

Aghion, P., A. Alesina, And F. Trebbi (2004): "Endogenous Political Institutions," The Quarterly Journal of Economics, 565-611.

Alesina, A. And P. Giuliano (2015): "Culture and institutions," Journal of Economic Literature, 53, 898-944.

Alesina, A., P. Giuliano, And N. Nunn (2013): "On the Origins of Gender Roles: Women and the Plough," The Quarterly Journal of Economics, 128, 469-530.

Allen, R. C. (1997): "Agriculture and the Origins of the State in Ancient Egypt," Explorations in Economic History, 34, 135-154.

ARnold, J. E. (1993): "Labor and the rise of complex hunter-gatherers," Journal of Anthropological Archaeology, 12, 75-119.

Ashraf, Q. And O. Galor (2013): "The "Out of Africa" Hypothesis, Human Genetic Diversity, and Comparative Economic Development," American Economic Review, 103, 1-46.

Ashraf, Q., O. Galor, And M. Klemp (2015): "Heterogeneity and Productivity," Brown University, Department of Economics, Working Paper.

Atkinson, Q. D. (2011): "Phonemic diversity supports a serial founder effect model of language expansion from Africa," Science, 332, 346-349.

Belfer-Cohen, A. and O. Bar-Yosef (2002): "Early Sedentism in the Near East," in Life in Neolithic Farming Communities, ed. by I. Kuijt, Springer US, Fundamental Issues in Archaeology, $19-38$.

Bentzen, J. S., N. KaArsen, And A. M. Wingender (2017): "Irrigation and autocracy," Journal of the European Economic Association.

Betti, L., N. von Cramon-Taubadel, A. Manica, and S. J. Lycett (2013): "Global geometric morphometric analyses of the human pelvis reveal substantial neutral population history effects, even across sexes," PloS one, 8, e55909.

Diamond, J. (1997): Guns, Germs, and Steel: The Fates of Human Societies, W.W. Norton.

Engerman, S. L. And K. L. Sokoloff (1997): "Factor endowments, institutions, and differential paths of growth among new world economies," How Latin America Fell Behind, 260-304.

Fenske, J. (2013): "Does land abundance explain African institutions?" The Economic Journal, 123, 1363-1390.

Fenske, J. (2014): "Ecology, Trade, and States in Pre-Colonial Africa," Journal of the European Economic Association, 12, 612-640.

Giuliano, P. And N. Nunn (2013): "The Transmission of Democracy: From the Village to the Nation-State," The American Economic Review, 103, 86.

Gosden, C. (1989): "Debt, production, and prehistory," Journal of Anthropological Archaeology, $8,355-387$.

HANiHARA, T. (2008): "Morphological variation of major human populations based on nonmetric dental traits," American journal of physical anthropology, 136, 169-182. 
Harris, I., P. Jones, T. Osborn, And D. Lister (2014): "Updated high-resolution grids of monthly climatic observations-the CRU TS3. 10 Dataset," International Journal of Climatology, $34,623-642$.

Henn, B. M., L. L. Cavalli-Sforza, And M. W. Feldman (2012): "The great human expansion," Proceedings of the National Academy of Sciences, 109, 17758-17764.

La Porta, R., F. Lopez-De-Silanes, A. Shleifer, and R. W. Vishny (1999): "The Quality of Government," Journal of Law, Economics, and Organization, 15, 222-279.

Lipset, S. M. (1960): Political Man: The Social Bases of Politics, Doubleday \& Garden, Inc., Garden City, New York.

Litina, A. (2014): "The Geographical Origins of Early State Formation," Center for Research in Economic Analysis, University of Luxembourg.

Manica, A., W. Amos, F. Balloux, and T. Hanihara (2007): "The effect of ancient population bottlenecks on human phenotypic variation," Nature, 448, 346-348.

Mann, M. (1986): The Sources of Social Power: Volume 1, A History of Power from the Beginning to $A D$ 1760, Cambridge paperback Library, Cambridge University Press.

Marshall, M. G., T. R. GurR, And K. Jaggers (2014): "Polity IV Project: Political Regime Characteristics and Transitions, 1800-2013: Dataset User's Manual," Tech. rep., Center for Systemic Peace.

Mayshar, J., O. Moav, Z. Neeman, and L. Pascali (2015): "Cereals, Appropriability and Hierarchy," CEPR Discussion Papers 10742, C.E.P.R. Discussion Papers.

Michalopoulos, S. (2012): "The origins of ethnolinguistic diversity," The American economic review, 102, 1508.

Murdock, G. P. (1967): "Ethnographic atlas: a summary," Ethnology, 109-236.

Murdock, G. P. And D. R. White (1969): "Standard cross-cultural sample," Ethnology, 329369.

Nunn, N. (2008): "The long-term effects of Africa's slave trades," The Quarterly Journal of Economics, 123, 139-176.

Pemberton, T. J., M. DeGiorgio, and N. A. Rosenberg (2013): "Population structure in a comprehensive genomic data set on human microsatellite variation," G3: Genes - GenomesGenetics, g3-113.

Ramachandran, S., O. Deshpande, C. C. Roseman, N. A. Rosenberg, M. W. Feldman, and L. L. Cavalli-Sforza (2005): "Support from the Relationship of Genetic and Geographic Distance in Human Populations for a Serial Founder Effect Originating in Africa," Proceedings of the National Academy of Sciences, 102, 15942-15947.

Ramankutty, N., J. A. Foley, J. Norman, and K. McSweeney (2002): "The Global Distribution of Cultivable Lands: Current Patterns and Sensitivity to Possible Climate Change," Global Ecology and Biogeography, 11, 377-392.

Siebert, S., V. Henrich, K. Frenken, And J. Burke (2013): "Global Map of Irrigation Areas version 5," Tech. rep., Rheinische Friedrich-Wilhelms-University, Bonn, Germany / Food and Agriculture Organization of the United Nations, Rome, Italy.

von Cramon-Taubadel, N. and S. J. Lycett (2008): "Brief communication: human cranial variation fits iterative founder effect model with African origin," American Journal of Physical Anthropology, 136, 108-113.

Wang, S., C. M. Lewis JR, M. Jakobsson, S. Ramachandran, N. Ray, G. Bedoya, W. Rojas, M. V. Parra, J. A. Molina, C. Gallo, et Al. (2007): "Genetic variation and population structure in Native Americans," PLoS Genetics, 3, e185. 


\author{
Online Appendix \\ Not For Publication
}




\section{A Additional Figures}

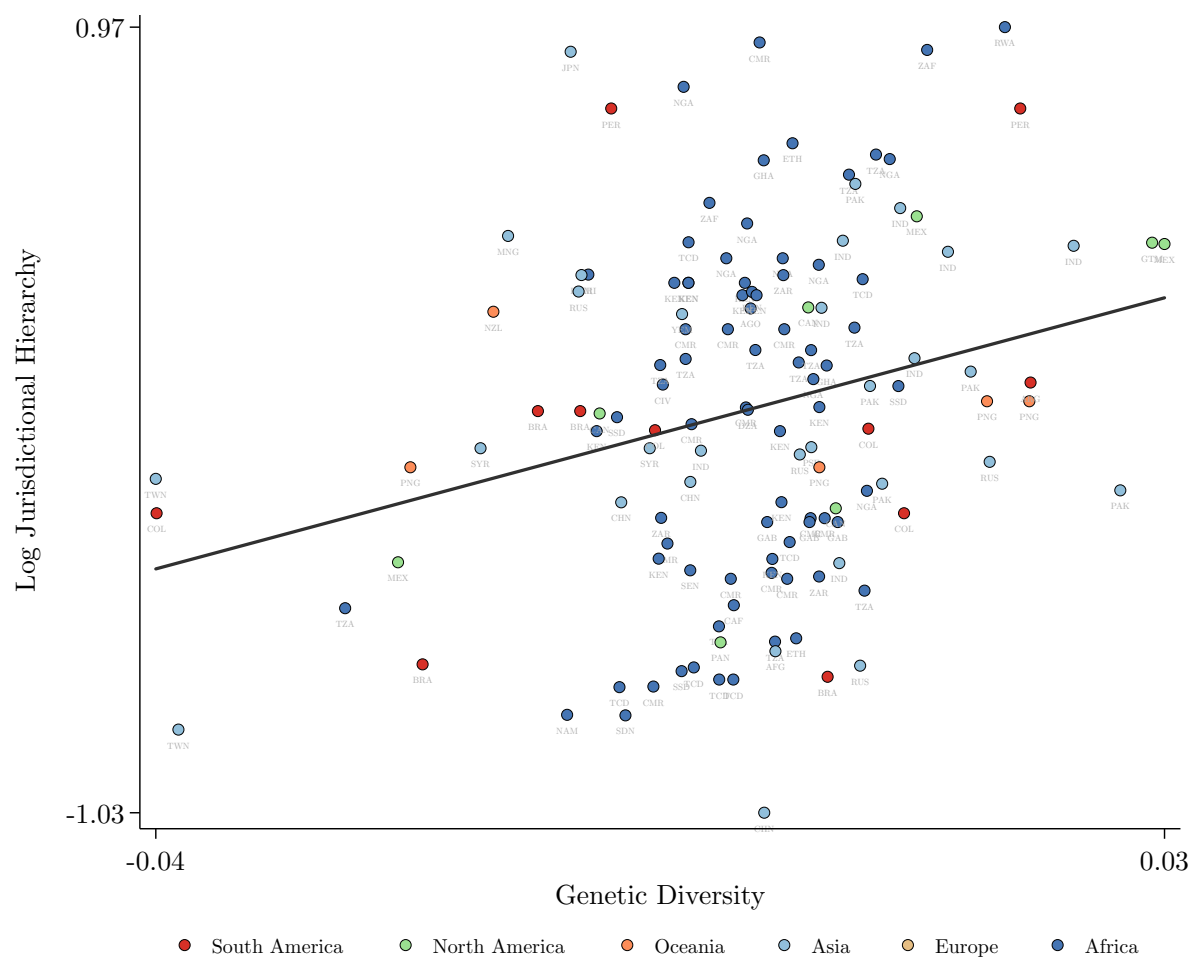

Panel A: The conditional association between genetic diversity and jurisdictional hierarchy, corresponding to column 6 of Table 1.

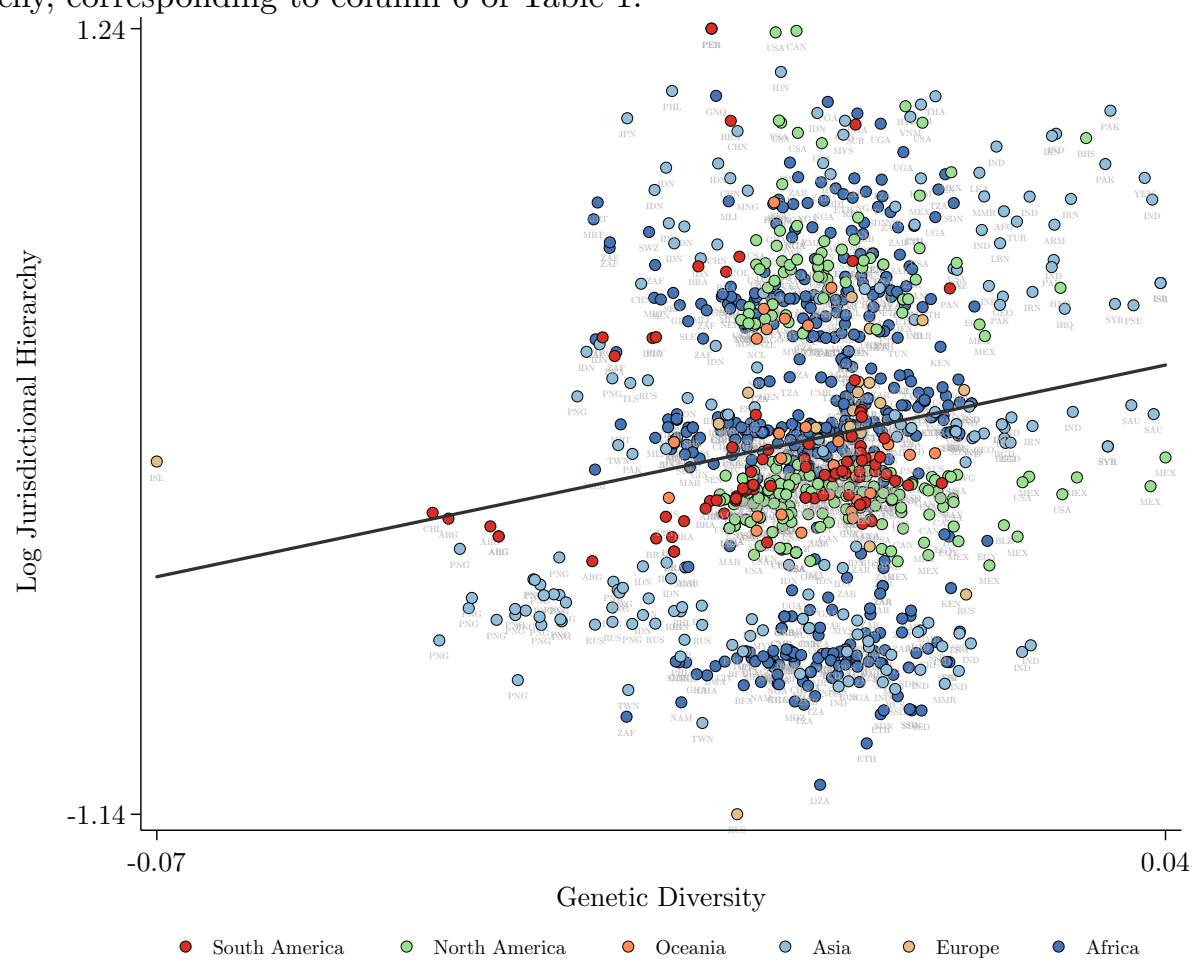

Panel B: The conditional effect of predicted genetic diversity on jurisdictional hierarchy, corresponding to column 6 of Table 3 .

Figure A.1: Genetic diversity and jurisdictional hierarchy: Added variable plots. 


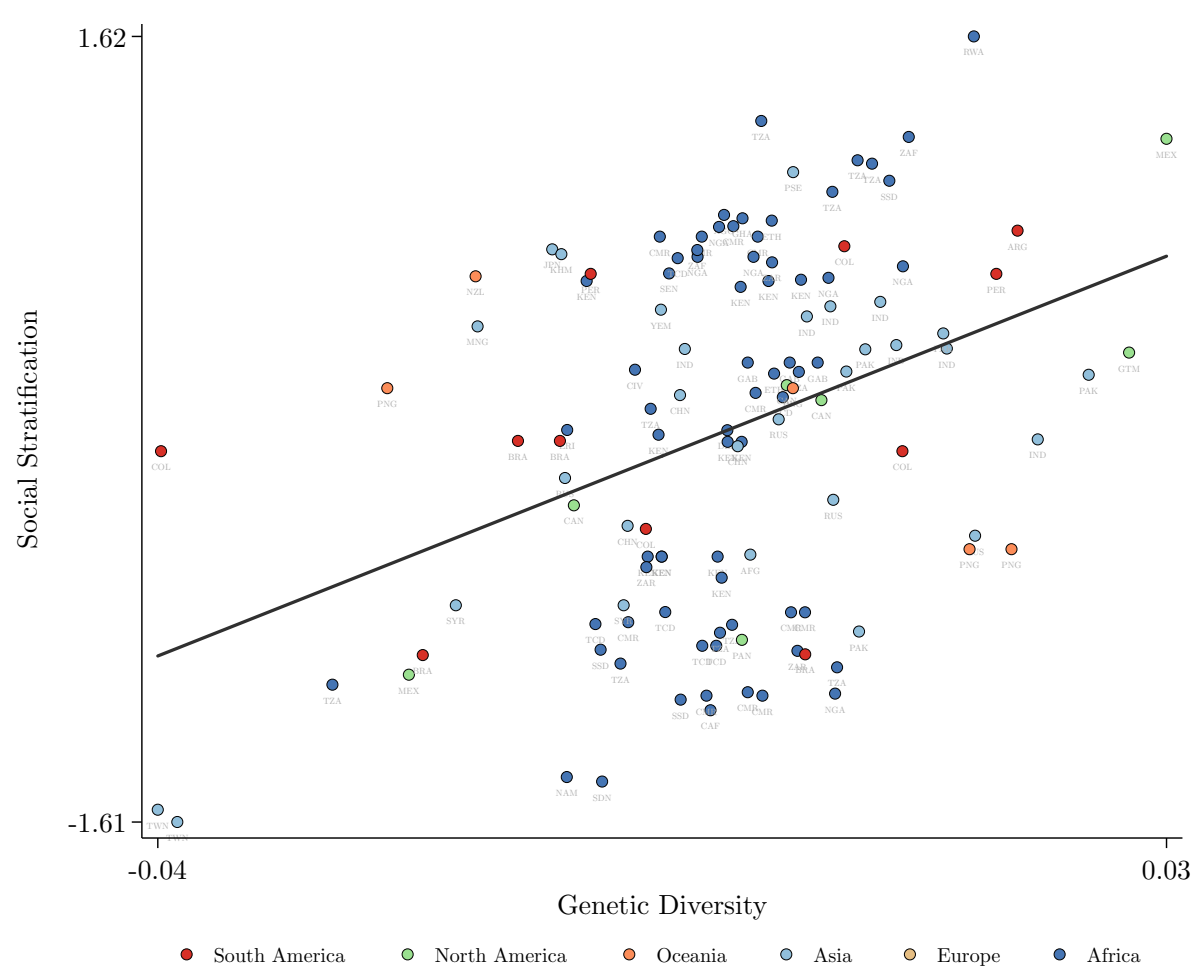

Panel A: The conditional association between genetic diversity and social stratification, corresponding to column 3 of Table 4 .

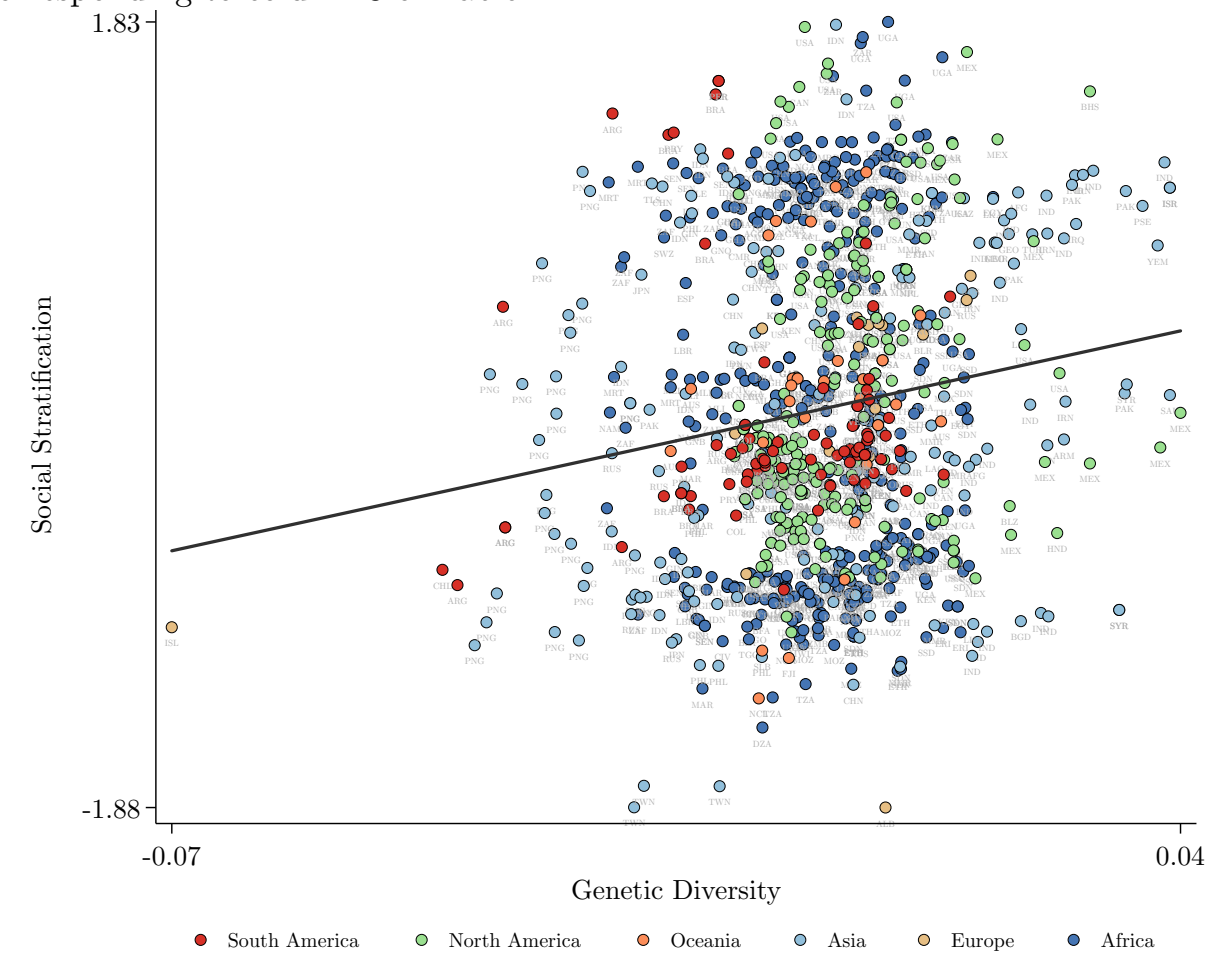

Panel B: The conditional effect of predicted genetic diversity on social stratification, corresponding to column 3 of Table 6 . 
Figure A.2: Genetic diversity and social stratification: Added variable plots.

Panel A: Intensity of Autocracy

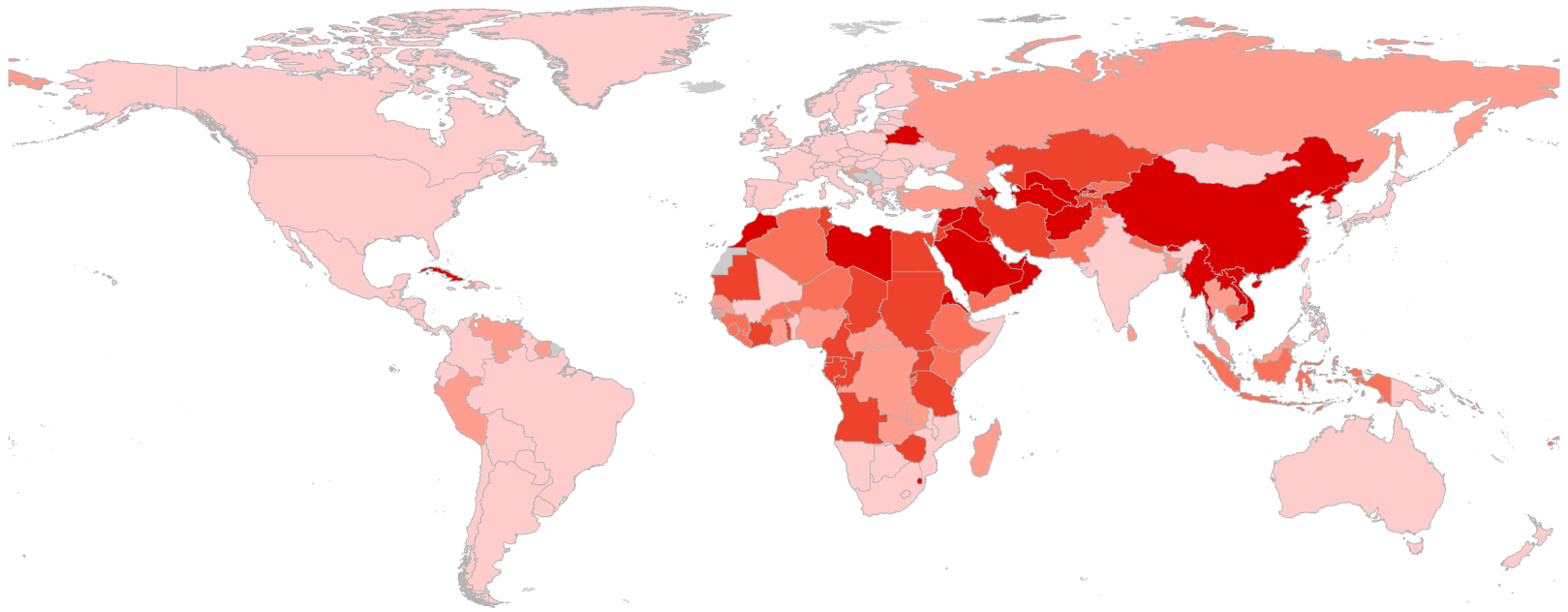

Panel B: Income per Capita

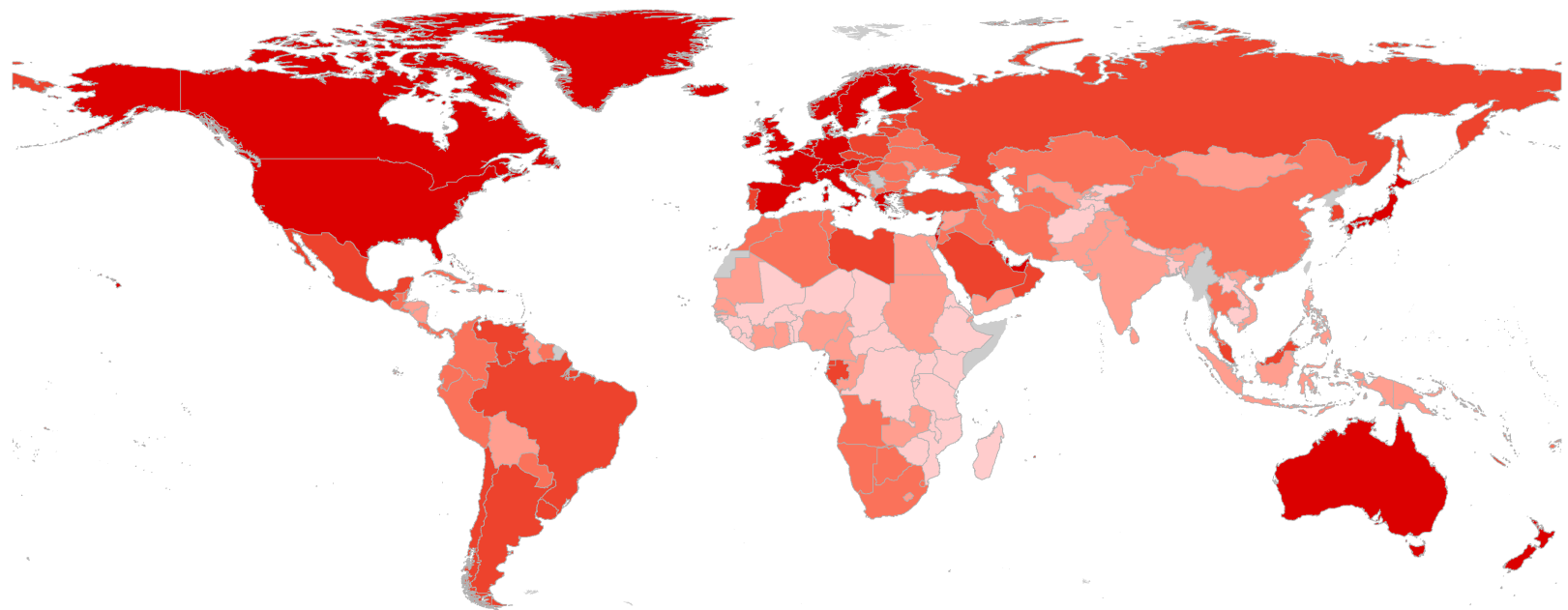

Figure A.3: The association between political institutions and economic development. Panel A: Intensity of autocracy across the globe (1994-2013). Panel B: Income per capita across the globe (1994-2011). 


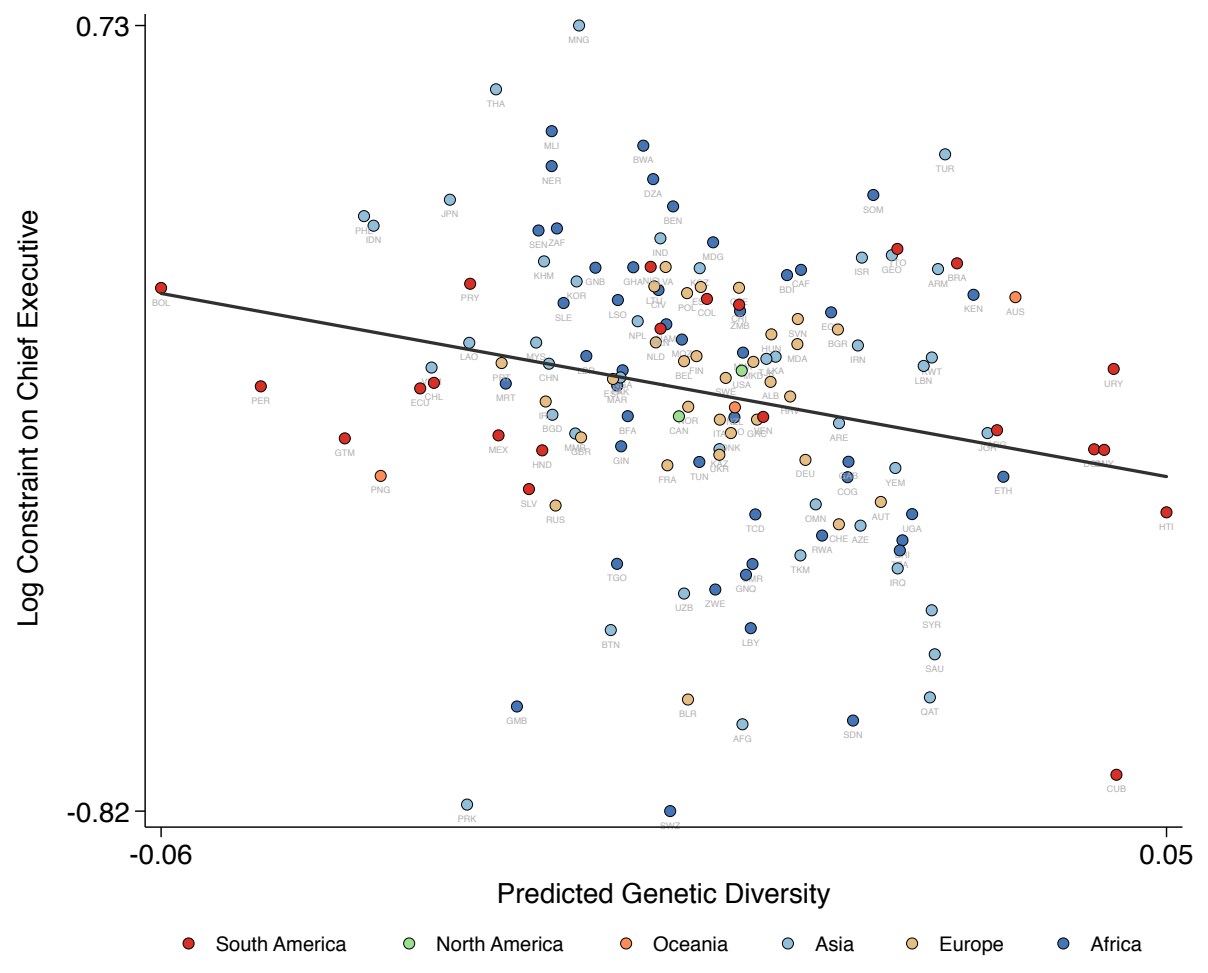

Figure A.4: The conditional effect of predicted genetic diversity and constraint on the executive, corresponding to column 3 of Table 12. 


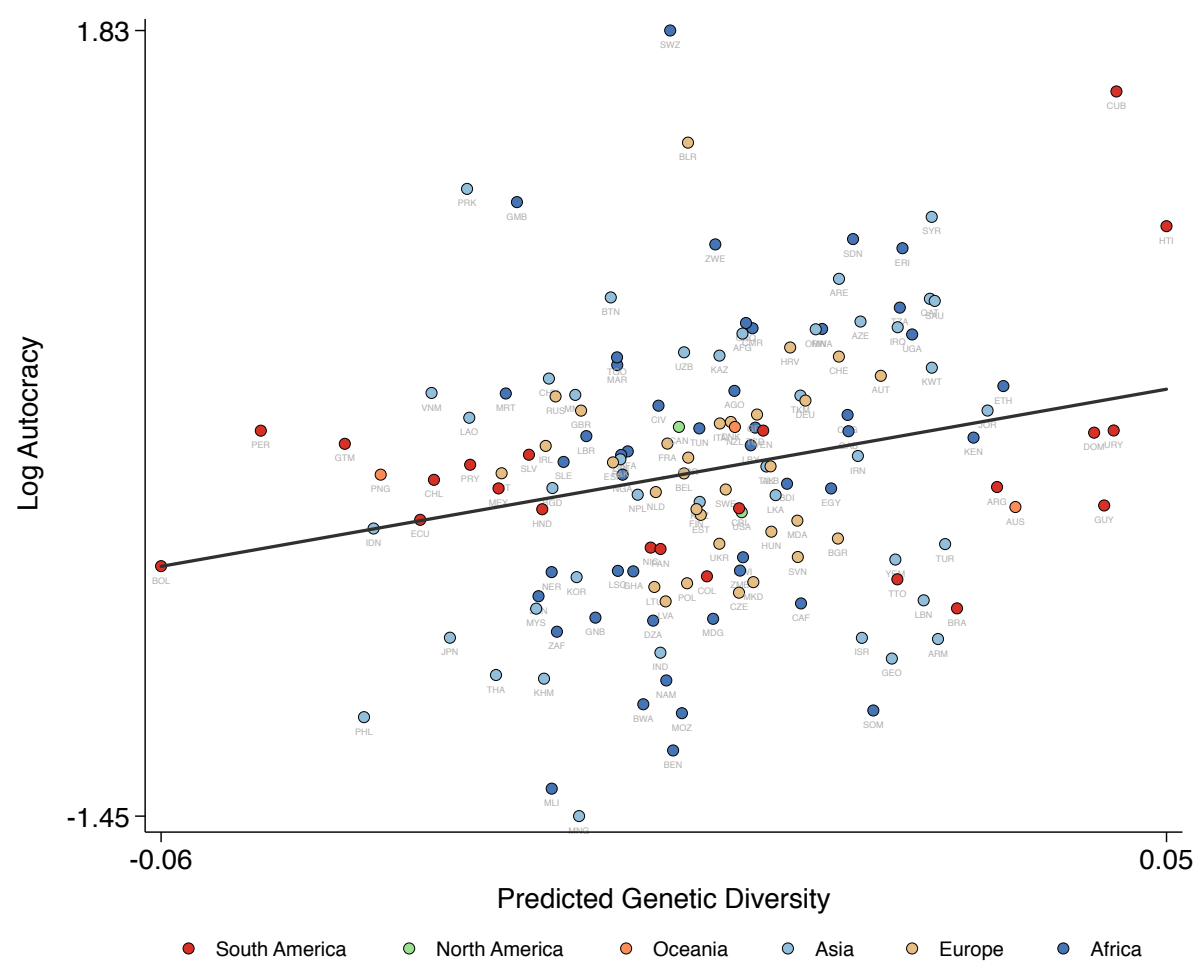

Figure A.5: The conditional effect of predicted genetic diversity on autocracy, corresponding to column 7 of Table 14 . 


\section{B Additional Tables}

Table B.1: Summary Statistics

\begin{tabular}{lccccc}
\hline & Average & S.D. & Min. & Max. & $N$ \\
\hline & & & & & \\
\multicolumn{2}{c}{ SummARY STATISTICS FOR THE PRE-COLONIAL } & ETHNIC-GROUP DATA & & \\
& & & & & \\
& & & & \\
& 0.51 & 0.51 & 0.00 & 1.61 & 1147 \\
Log Levels of Jurisdictional Hierarchy & 0.79 & 0.86 & 0.00 & 2.00 & 1102 \\
Social Stratification & 0.73 & 0.78 & 0.00 & 2.00 & 1113 \\
Intensity of Slavery & 1.17 & 0.84 & 0.00 & 3.00 & 86 \\
Degree of Absence of Checks on Leader's Power & 1.29 & 0.98 & 0.00 & 3.00 & 77 \\
Difficulty of Removal of Leaders & 0.85 & 0.83 & 0.00 & 2.00 & 87 \\
Leader's Exercise of Authority & 0.87 & 0.80 & 0.00 & 2.00 & 90 \\
Degree of Lack of Community Decisions & 0.86 & 0.82 & 0.00 & 2.00 & 90 \\
Perception of Leader's Power & 0.94 & 0.35 & 0.00 & 1.10 & 923 \\
Log Intensity of Indigenous Autocracy & 0.83 & 0.24 & 0.00 & 1.10 & 1177 \\
Log Indigenous Autocracy (Ancestry Adjusted) & 0.33 & 0.34 & 0.00 & 1.00 & 1188 \\
Indigenous Democracy & 0.32 & 0.31 & 0.00 & 1.00 & 1188 \\
Indigenous Democracy (Ancestry Adjusted) & 0.94 & 0.18 & 0.00 & 1.10 & 1180 \\
Log Indigenous Autocracy & 8.05 & 45.20 & 0.00 & 1327.70 & 1097 \\
Area & 0.73 & 0.05 & 0.58 & 0.77 & 145 \\
Observed Genetic Diversity & 0.71 & 0.04 & 0.59 & 0.77 & 1263 \\
Predicted Genetic Diversity & 635.73 & 731.65 & -2342.33 & 4527.95 & 1263 \\
Elevation & 2.90 & 17.24 & 0.00 & 490.54 & 1097 \\
River Length & 0.81 & 5.04 & 0.00 & 108.87 & 1097 \\
River Density & 0.11 & 0.26 & 0.00 & 1.00 & 1097 \\
Share Desert & 19.88 & 8.40 & -18.91 & 29.54 & 1253 \\
Average Temperature & 11.67 & 2.83 & 4.57 & 19.38 & 1253 \\
Temperature Range & 0.91 & 0.29 & 0.00 & 1.00 & 1097 \\
Any diversity (FAO) & 0.42 & 0.25 & 0.00 & 0.84 & 1097 \\
Ecological diversity (FAO classes) & 1895.64 & 154.70 & -800.00 & 2000.00 & 1275 \\
Year in Ethnographic Atlas & $1.2 \mathrm{e}+05$ & $1.3 \mathrm{e}+05$ & 0.00 & $1.0 \mathrm{e}+06$ & 1263 \\
Terrain Ruggedness & & & &
\end{tabular}

Summary Statistics for the Modern-Country Data

Log Constraint on Chief Executive

Log Autocracy

Log Democracy

Predicted Genetic Diversity

Log Absolute Latitude

Soil Fertility

Roughness

Elevation

Average Distance to Nearest Waterway

Percentage of Arable Land

Temperature

Africa dummy

Asia dummy

Europe dummy

Oceania dummy

Latin America and Caribbean region dummy

Sub-Saharan Africa region dummy

British legal origin dummy

French legal origin dummy

Socialist legal origin dummy

German legal origin dummy

Scandinavian legal origin dummy

Colony

$\begin{array}{ccccc}1.68 & 0.40 & 0.69 & 2.08 & 147 \\ 0.78 & 0.83 & 0.00 & 2.40 & 147 \\ 1.53 & 0.88 & 0.00 & 2.40 & 147 \\ 0.73 & 0.03 & 0.63 & 0.77 & 150 \\ 2.96 & 0.96 & 0.00 & 4.17 & 154 \\ 0.57 & 0.20 & 0.00 & 0.96 & 154 \\ 0.18 & 0.14 & 0.01 & 0.60 & 154 \\ 0.56 & 0.49 & 0.02 & 2.67 & 154 \\ 0.34 & 0.45 & 0.01 & 2.39 & 154 \\ 15.13 & 13.80 & 0.04 & 62.10 & 154 \\ 18.09 & 8.49 & -7.93 & 28.64 & 154 \\ 0.31 & 0.46 & 0.00 & 1.00 & 154 \\ 0.27 & 0.45 & 0.00 & 1.00 & 154 \\ 0.23 & 0.42 & 0.00 & 1.00 & 154 \\ 0.02 & 0.14 & 0.00 & 1.00 & 154 \\ 0.16 & 0.36 & 0.00 & 1.00 & 154 \\ 0.27 & 0.45 & 0.00 & 1.00 & 154 \\ 0.26 & 0.44 & 0.00 & 1.00 & 154 \\ 0.45 & 0.50 & 0.00 & 1.00 & 154 \\ 0.22 & 0.42 & 0.00 & 1.00 & 154 \\ 0.03 & 0.18 & 0.00 & 1.00 & 154 \\ 0.03 & 0.18 & 0.00 & 1.00 & 154 \\ 0.64 & 0.48 & 0.00 & 1.00 & 153\end{array}$




\section{Table B.2: Predicted Diversity and Jurisdictional Hierarchy — Omitted Variables and Bootstrapped Standard Errors}

\begin{tabular}{|c|c|c|c|c|c|c|}
\hline & \multicolumn{6}{|c|}{ Log Number of Levels of Jurisdictional Hierarchy } \\
\hline & $(1)$ & $(2)$ & $(3)$ & (4) & $(5)$ & (6) \\
\hline Predicted Genetic Diversity & $\begin{array}{c}5.121^{* * *} \\
(0.293)\end{array}$ & $\begin{array}{c}5.771^{* * *} \\
(0.320)\end{array}$ & $\begin{array}{c}5.838^{* * *} \\
(0.317)\end{array}$ & $\begin{array}{c}5.496^{* * *} \\
(1.010)\end{array}$ & $\begin{array}{c}5.732^{* * *} \\
(1.097)\end{array}$ & $\begin{array}{c}5.949^{* * *} \\
(1.106)\end{array}$ \\
\hline Log Absolute Latitude & & $\begin{array}{c}0.068^{* * *} \\
(0.013)\end{array}$ & $\begin{array}{c}0.080^{* * *} \\
(0.014)\end{array}$ & $\begin{array}{c}0.110^{* * *} \\
(0.018)\end{array}$ & $\begin{array}{c}0.109^{* * *} \\
(0.019)\end{array}$ & $\begin{array}{c}0.130^{* * *} \\
(0.021)\end{array}$ \\
\hline Elevation & & & & & $\begin{array}{c}0.000 \\
(0.000)\end{array}$ & $\begin{array}{l}0.000^{* *} \\
(0.000)\end{array}$ \\
\hline Terrain Ruggedness & & & & & $\begin{array}{c}-0.000^{*} \\
(0.000)\end{array}$ & $\begin{array}{c}-0.000^{* * *} \\
(0.000)\end{array}$ \\
\hline River Length & & & & & $\begin{array}{l}0.003^{* *} \\
(0.001)\end{array}$ & $\begin{array}{c}0.003^{* * *} \\
(0.001)\end{array}$ \\
\hline River Density & & & & & $\begin{array}{l}-0.003 \\
(0.002)\end{array}$ & $\begin{array}{c}-0.002 \\
(0.002)\end{array}$ \\
\hline Share Desert & & & & & $\begin{array}{c}0.011 \\
(0.062)\end{array}$ & $\begin{array}{c}0.019 \\
(0.072)\end{array}$ \\
\hline Average Temperature & & & & & & $\begin{array}{c}0.007^{*} \\
(0.004)\end{array}$ \\
\hline Temperature Range & & & & & & $\begin{array}{c}-0.020^{* *} \\
(0.008)\end{array}$ \\
\hline Soil Quality (Climatic) & No & No & Yes & Yes & Yes & Yes \\
\hline Continental FE & No & No & No & Yes & Yes & Yes \\
\hline $\begin{array}{l}\text { Bootstrapped Standard Error } \\
\text { Altonji, Elder and Taber }(2005) \text { / Bellows and Miguel (2009) } \\
\text { Oster (2014) bias-adjusted } \beta\end{array}$ & $(0.656)^{* * *}$ & $(0.738)^{* * *}$ & $(0.735)^{* * *}$ & $(1.359)^{* * *}$ & $\begin{array}{c}(1.439)^{* * *} \\
-20.897 \\
6.877\end{array}$ & $\begin{array}{l}(1.412)^{* * *} \\
-12.120 \\
7.565\end{array}$ \\
\hline $\begin{array}{l}\text { Adjusted } R^{2} \\
N\end{array}$ & $\begin{array}{l}0.199 \\
1,076\end{array}$ & $\begin{array}{l}0.217 \\
1,076\end{array}$ & $\begin{array}{l}0.225 \\
1,076\end{array}$ & $\begin{array}{l}0.290 \\
1,076\end{array}$ & $\begin{array}{l}0.297 \\
1,076\end{array}$ & $\begin{array}{l}0.300 \\
1,076\end{array}$ \\
\hline $\begin{array}{l}\text { This table presents the results of a series of OLS regression analy } \\
\text { (the natural logarithm of the number of levels of jurisdictional hi } \\
\text { Africa to the interior centroid of the homeland of the ethnicity, con } \\
\text { bootstrapped standard errors that account for the uncertainty in } \\
\text { from East Africa. Furthermore, the table includes omitted variab } \\
\text { Africa, Latin America, and continental fixed effects. Heteroscedast } \\
\text { percent level. ** Significant at the } 5 \text { percent level. * Significant at }\end{array}$ & $\begin{array}{l}\text {, on the etl } \\
\text { rchy) on pre } \\
\text { ional on a re } \\
\text { first stage } \\
\text { tatistics. Sp } \\
\text { y-consistent } \\
\text { e } 10 \text { percent }\end{array}$ & $\begin{array}{l}\text { ic-group lev } \\
\text { icted geneti } \\
\text { ge of contro } \\
\text { the predict } \\
\text { ifications } \mathrm{m} \\
\text { tandard err } \\
\text { vel. }\end{array}$ & $\begin{array}{l}\text { of a measl } \\
\text { diversity, bc } \\
\text { ariables at } \\
\text { of genetic } \\
\text { ked with "c } \\
\text { are report }\end{array}$ & $\begin{array}{l}\text { of pre-colc } \\
\text { on the } \mathrm{m} \\
\text { ethnic-gro } \\
\text { ersity base } \\
\text { tinental FI } \\
\text { in parenthe }\end{array}$ & $\begin{array}{l}\text { jurisdicti } \\
\text { tory dista } \\
\text { evel. The } \\
\text { the migr } \\
\text { ccounts fo } \\
* * * \text { Signi }\end{array}$ & $\begin{array}{l}\text { 1 hierarchy } \\
\text { from East } \\
\text { le includes } \\
\text { ry distance } \\
\text { ab-Saharan } \\
\text { nt at the } 1\end{array}$ \\
\hline
\end{tabular}


Table B.3: Predicted Diversity and Autocratic Institutions — Omitted Variables and Bootstrapped Standard Errors

\begin{tabular}{|c|c|c|c|c|c|c|c|c|c|c|}
\hline & \multicolumn{2}{|c|}{$\begin{array}{l}\text { Degree of Absence } \\
\text { of Checks on } \\
\text { Leader's Power }\end{array}$} & \multicolumn{2}{|c|}{$\begin{array}{l}\text { Difficulty of } \\
\text { Removal of } \\
\text { Leaders }\end{array}$} & \multicolumn{2}{|c|}{$\begin{array}{c}\text { Leader's Exercise } \\
\text { of Authority }\end{array}$} & \multicolumn{2}{|c|}{$\begin{array}{l}\text { Degree of Lack of } \\
\text { Community } \\
\text { Decisions }\end{array}$} & \multicolumn{2}{|c|}{$\begin{array}{l}\text { Perception of } \\
\text { Leader's Power }\end{array}$} \\
\hline & $(1)$ & $(2)$ & $(3)$ & $(4)$ & $(5)$ & $(6)$ & (7) & $(8)$ & (9) & $(10)$ \\
\hline Predicted Genetic Diversity & $\begin{array}{l}6.317^{* * *} \\
(2.101)\end{array}$ & $\begin{array}{l}5.042^{* *} \\
(2.306)\end{array}$ & $\begin{array}{c}7.374^{* * *} \\
(2.222)\end{array}$ & $\begin{array}{l}5.858^{* *} \\
(2.236)\end{array}$ & $\begin{array}{c}6.048^{* * *} \\
(1.895)\end{array}$ & $\begin{array}{c}5.489^{* * *} \\
(1.984)\end{array}$ & $\begin{array}{l}6.589^{* * *} \\
(1.514)\end{array}$ & $\begin{array}{c}6.023^{* * *} \\
(1.679)\end{array}$ & $\begin{array}{c}5.529^{* * *} \\
(1.753)\end{array}$ & $\begin{array}{l}5.504^{* *} \\
(2.094)\end{array}$ \\
\hline Log Absolute Latitude & $\begin{array}{c}0.035 \\
(0.099)\end{array}$ & $\begin{array}{l}-0.080 \\
(0.189)\end{array}$ & $\begin{array}{c}0.143 \\
(0.092)\end{array}$ & $\begin{array}{c}0.111 \\
(0.148)\end{array}$ & $\begin{array}{l}-0.053 \\
(0.091)\end{array}$ & $\begin{array}{l}-0.030 \\
(0.173)\end{array}$ & $\begin{array}{l}-0.100 \\
(0.069)\end{array}$ & $\begin{array}{l}-0.044 \\
(0.120)\end{array}$ & $\begin{array}{c}0.026 \\
(0.087)\end{array}$ & $\begin{array}{c}0.090 \\
(0.144)\end{array}$ \\
\hline Elevation & & $\begin{array}{l}-0.000 \\
(0.000)\end{array}$ & & $\begin{array}{l}-0.000 \\
(0.000)\end{array}$ & & $\begin{array}{l}-0.000 \\
(0.000)\end{array}$ & & $\begin{array}{c}0.000 \\
(0.000)\end{array}$ & & $\begin{array}{l}0.000 \\
(0.000)\end{array}$ \\
\hline Terrain Ruggedness & & $\begin{array}{l}0.000^{*} \\
(0.000)\end{array}$ & & $\begin{array}{l}0.000^{* *} \\
(0.000)\end{array}$ & & $\begin{array}{c}0.000 \\
(0.000)\end{array}$ & & $\begin{array}{c}0.000 \\
(0.000)\end{array}$ & & $\begin{array}{l}-0.000 \\
(0.000)\end{array}$ \\
\hline River Length & & $\begin{array}{c}0.013 \\
(0.009)\end{array}$ & & $\begin{array}{l}-0.000 \\
(0.010)\end{array}$ & & $\begin{array}{c}0.008 \\
(0.007)\end{array}$ & & $\begin{array}{c}0.001 \\
(0.007)\end{array}$ & & $\begin{array}{l}0.014^{*} \\
(0.007)\end{array}$ \\
\hline River Density & & $\begin{array}{l}-0.061 \\
(0.050)\end{array}$ & & $\begin{array}{l}-0.031 \\
(0.040)\end{array}$ & & $\begin{array}{l}-0.044 \\
(0.033)\end{array}$ & & $\begin{array}{l}-0.016 \\
(0.041)\end{array}$ & & $\begin{array}{l}-0.043 \\
(0.033)\end{array}$ \\
\hline Share Desert & & $\begin{array}{c}0.235 \\
(0.533)\end{array}$ & & $\begin{array}{c}0.157 \\
(0.613)\end{array}$ & & $\begin{array}{l}-0.561 \\
(0.543)\end{array}$ & & $\begin{array}{c}0.072 \\
(0.479)\end{array}$ & & $\begin{array}{c}0.125 \\
(0.473)\end{array}$ \\
\hline Average Temperature & & $\begin{array}{l}-0.003 \\
(0.020)\end{array}$ & & $\begin{array}{c}0.014 \\
(0.021)\end{array}$ & & $\begin{array}{c}0.020 \\
(0.019)\end{array}$ & & $\begin{array}{c}0.015 \\
(0.015)\end{array}$ & & $\begin{array}{c}0.011 \\
(0.017)\end{array}$ \\
\hline Temperature Range & & $\begin{array}{c}0.091 \\
(0.068)\end{array}$ & & $\begin{array}{c}0.087 \\
(0.067)\end{array}$ & & $\begin{array}{c}0.061 \\
(0.063)\end{array}$ & & $\begin{array}{l}-0.013 \\
(0.049)\end{array}$ & & $\begin{array}{l}-0.047 \\
(0.054)\end{array}$ \\
\hline Soil Quality (Climatic) & Yes & Yes & Yes & Yes & Yes & Yes & Yes & Yes & Yes & Yes \\
\hline Bootstrapped standard error & $(2.423)^{* * *}$ & $(2.627)^{* *}$ & $(2.548)^{* * *}$ & $(2.485)^{* *}$ & $(2.244)^{* * *}$ & $(2.411)^{* *}$ & $(1.672)^{* * *}$ & $(1.809)^{* * *}$ & $(2.065)^{* * *}$ & $(2.197)^{* *}$ \\
\hline Altonji, Elder and Taber (2005) / Bellows and Miguel (2009) & & 3.955 & & 3.863 & & 9.819 & & 10.638 & & 221.800 \\
\hline Oster (2014) bias-adjusted $\beta$ & & 4.013 & & 4.762 & & 4.734 & & 4.015 & & 5.426 \\
\hline Adjusted $R^{2}$ & 0.067 & 0.111 & 0.079 & 0.168 & 0.121 & 0.109 & 0.198 & 0.146 & 0.164 & 0.108 \\
\hline$N$ & 78 & 78 & 71 & 71 & 79 & 79 & 82 & 82 & 82 & 82 \\
\hline
\end{tabular}


Table B.4: Diversity and Jurisdictional Hierarchy — Ordered Probit

\begin{tabular}{|c|c|c|c|c|c|c|}
\hline & \multicolumn{6}{|c|}{ Number of Levels of Jurisdictional Hierarchy } \\
\hline & (1) & (2) & (3) & (4) & (5) & (6) \\
\hline Genetic Diversity & $\begin{array}{l}5.195^{* *} \\
(2.436)\end{array}$ & $\begin{array}{c}10.143^{* * *} \\
(3.139)\end{array}$ & $\begin{array}{c}12.350^{* * *} \\
(3.022)\end{array}$ & $\begin{array}{c}29.074^{* * *} \\
(8.399)\end{array}$ & $\begin{array}{c}33.998^{* * *} \\
(10.047)\end{array}$ & $\begin{array}{c}31.789^{* * *} \\
(9.652)\end{array}$ \\
\hline Log Absolute Latitude & & $\begin{array}{c}0.379^{* * *} \\
(0.089)\end{array}$ & $\begin{array}{c}0.443^{* * *} \\
(0.101)\end{array}$ & $\begin{array}{c}0.304^{* * *} \\
(0.099)\end{array}$ & $\begin{array}{l}0.268^{* *} \\
(0.114)\end{array}$ & $\begin{array}{l}0.333^{* *} \\
(0.130)\end{array}$ \\
\hline Elevation & & & & & $\begin{array}{c}-0.000 \\
(0.000)\end{array}$ & $\begin{array}{c}0.000 \\
(0.000)\end{array}$ \\
\hline Terrain Ruggedness & & & & & $\begin{array}{c}0.000 \\
(0.000)\end{array}$ & $\begin{array}{c}0.000 \\
(0.000)\end{array}$ \\
\hline River Length & & & & & $\begin{array}{c}0.006^{* * *} \\
(0.003)\end{array}$ & $\begin{array}{l}0.022^{*} \\
(0.013)\end{array}$ \\
\hline River Density & & & & & $\begin{array}{c}-0.170 \\
(0.109)\end{array}$ & $\begin{array}{l}-0.066 \\
(0.106)\end{array}$ \\
\hline Share Desert & & & & & $\begin{array}{c}-0.711 \\
(0.659)\end{array}$ & $\begin{array}{c}-1.385^{* *} \\
(0.661)\end{array}$ \\
\hline Average Temperature & & & & & & $\begin{array}{c}0.081^{*} \\
(0.042)\end{array}$ \\
\hline Temperature Range & & & & & & $\begin{array}{c}0.031 \\
(0.063)\end{array}$ \\
\hline Soil Quality (Climatic) & No & No & Yes & Yes & Yes & Yes \\
\hline Continental FE & No & No & No & Yes & Yes & Yes \\
\hline$N$ & 131 & 131 & 131 & 131 & 131 & 131 \\
\hline
\end{tabular}

This table presents the results of a series of ordered probit regression analyses, on the ethnic-group level, of a measure of pre-colonial jurisdictional hierarchy (the number of levels of jurisdictional hierarchy) on observed genetic diversity, conditional on a range of control variables at the ethnicgroup level. Specifications marked with "Continental FE" accounts for sub-Saharan Africa, Latin America, and continental fixed effects. Heteroscedasticity-consistent standard errors are reported in parentheses. ${ }^{* * *}$ Significant at the 1 percent level. ${ }^{* *}$ Significant at the 5 percent level. ${ }^{*}$ Significant at the 10 percent level. 
Table B.5: Predicted Diversity and Jurisdictional Hierarchy — Ordered Probit

\begin{tabular}{|c|c|c|c|c|c|c|}
\hline & \multicolumn{6}{|c|}{ Log Number of Levels of Jurisdictional Hierarchy } \\
\hline & $(1)$ & $(2)$ & $(3)$ & $(4)$ & $(5)$ & (6) \\
\hline Predicted Genetic Diversity & $\begin{array}{c}12.672^{* * *} \\
(0.968)\end{array}$ & $\begin{array}{c}15.294^{* * *} \\
(1.285)\end{array}$ & $\begin{array}{c}15.774^{* * *} \\
(1.274)\end{array}$ & $\begin{array}{c}12.562^{* * *} \\
(2.626)\end{array}$ & $\begin{array}{c}13.713^{* * *} \\
(2.987)\end{array}$ & $\begin{array}{c}14.761^{* * *} \\
(3.062)\end{array}$ \\
\hline Log Absolute Latitude & & $\begin{array}{c}0.208^{* * *} \\
(0.039)\end{array}$ & $\begin{array}{c}0.245^{* * *} \\
(0.041)\end{array}$ & $\begin{array}{c}0.278^{* * *} \\
(0.049)\end{array}$ & $\begin{array}{c}0.269^{* * *} \\
(0.052)\end{array}$ & $\begin{array}{c}0.341^{* * *} \\
(0.062)\end{array}$ \\
\hline Elevation & & & & & $\begin{array}{c}0.000 \\
(0.000)\end{array}$ & $\begin{array}{c}0.000^{* *} \\
(0.000)\end{array}$ \\
\hline Terrain Ruggedness & & & & & $\begin{array}{l}-0.000 \\
(0.000)\end{array}$ & $\begin{array}{c}-0.000^{* *} \\
(0.000)\end{array}$ \\
\hline River Length & & & & & $\begin{array}{c}0.017^{* * *} \\
(0.005)\end{array}$ & $\begin{array}{c}0.020^{* * *} \\
(0.005)\end{array}$ \\
\hline River Density & & & & & $\begin{array}{c}-0.013^{*} \\
(0.007)\end{array}$ & $\begin{array}{l}-0.013^{*} \\
(0.007)\end{array}$ \\
\hline Share Desert & & & & & $\begin{array}{l}-0.003 \\
(0.187)\end{array}$ & $\begin{array}{l}-0.004 \\
(0.207)\end{array}$ \\
\hline Average Temperature & & & & & & $\begin{array}{c}0.024^{* *} \\
(0.011)\end{array}$ \\
\hline Temperature Range & & & & & & $\begin{array}{c}-0.062^{* * * *} \\
(0.022)\end{array}$ \\
\hline Soil Quality (Climatic) & No & No & Yes & Yes & Yes & Yes \\
\hline Continental FE & No & No & No & Yes & Yes & Yes \\
\hline$N$ & 1,076 & 1,076 & 1,076 & 1,076 & 1,076 & 1,076 \\
\hline
\end{tabular}

This table presents the results of a series of ordered probit regression analyses, on the ethnic-group level, of a measure of pre-colonial jurisdictional hierarchy (the number of levels of jurisdictional hierarchy) on predicted genetic diversity, based on the migratory distance from East Africa to the interior centroid of the homeland of the ethnicity, conditional on a range of control variables at the ethnic-group level. Specifications marked with "Continental FE" accounts for sub-Saharan Africa, Latin America, and continental fixed effects. Heteroscedasticity-consistent standard errors are reported in parentheses. *** Significant at the 1 percent level. ** Significant at the 5 percent level. * Significant at the 10 percent level. 
Table B.6: Jurisdictional Hierarchy and Autocratic Institutions - Ordered Probit

\begin{tabular}{|c|c|c|c|c|c|c|c|c|c|c|}
\hline & \multicolumn{2}{|c|}{$\begin{array}{l}\text { Degree of Absence } \\
\text { of Checks on } \\
\text { Leader's Power }\end{array}$} & \multicolumn{2}{|c|}{$\begin{array}{l}\text { Difficulty of } \\
\text { Removal of } \\
\text { Leaders }\end{array}$} & \multicolumn{2}{|c|}{$\begin{array}{l}\text { Leader's Exercise } \\
\text { of Authority }\end{array}$} & \multicolumn{2}{|c|}{$\begin{array}{l}\text { Degree of Lack of } \\
\text { Community } \\
\text { Decisions }\end{array}$} & \multicolumn{2}{|c|}{$\begin{array}{l}\text { Perception of } \\
\text { Leader's Power }\end{array}$} \\
\hline & (1) & $(2)$ & $(3)$ & $(4)$ & $(5)$ & (6) & (7) & $(8)$ & $(9)$ & $(10)$ \\
\hline Log Levels of Jurisdictional Hierarchy & $\begin{array}{c}1.417^{* * *} \\
(0.268)\end{array}$ & $\begin{array}{c}1.307^{* * *} \\
(0.295)\end{array}$ & $\begin{array}{c}1.315^{* * *} \\
(0.309)\end{array}$ & $\begin{array}{c}1.279^{* * *} \\
(0.324)\end{array}$ & $\begin{array}{c}1.755^{* * *} \\
(0.307)\end{array}$ & $\begin{array}{c}1.793^{* * *} \\
(0.325)\end{array}$ & $\begin{array}{c}1.820^{* * *} \\
(0.308)\end{array}$ & $\begin{array}{c}1.927^{* * *} \\
(0.347)\end{array}$ & $\begin{array}{c}1.653^{* * *} \\
(0.301)\end{array}$ & $\begin{array}{c}1.612^{* * *} \\
(0.313)\end{array}$ \\
\hline Log Absolute Latitude & $\begin{array}{l}-0.044 \\
(0.125)\end{array}$ & $\begin{array}{l}-0.205 \\
(0.239)\end{array}$ & $\begin{array}{c}0.061 \\
(0.119)\end{array}$ & $\begin{array}{c}0.068 \\
(0.200)\end{array}$ & $\begin{array}{l}-0.250^{*} \\
(0.138)\end{array}$ & $\begin{array}{l}-0.097 \\
(0.227)\end{array}$ & $\begin{array}{c}-0.369^{* * *} \\
(0.127)\end{array}$ & $\begin{array}{l}-0.262 \\
(0.215)\end{array}$ & $\begin{array}{l}-0.063 \\
(0.137)\end{array}$ & $\begin{array}{c}0.068 \\
(0.193)\end{array}$ \\
\hline Elevation & & $\begin{array}{l}-0.000 \\
(0.001)\end{array}$ & & $\begin{array}{l}-0.000 \\
(0.000)\end{array}$ & & $\begin{array}{l}-0.000 \\
(0.001)\end{array}$ & & $\begin{array}{c}0.000 \\
(0.000)\end{array}$ & & $\begin{array}{c}0.001 \\
(0.000)\end{array}$ \\
\hline Terrain Ruggedness & & $\begin{array}{c}0.000^{*} \\
(0.000)\end{array}$ & & $\begin{array}{l}0.000^{* *} \\
(0.000)\end{array}$ & & $\begin{array}{c}0.000 \\
(0.000)\end{array}$ & & $\begin{array}{c}0.000 \\
(0.000)\end{array}$ & & $\begin{array}{l}-0.000 \\
(0.000)\end{array}$ \\
\hline River Length & & $\begin{array}{c}0.011 \\
(0.011)\end{array}$ & & $\begin{array}{l}-0.011 \\
(0.013)\end{array}$ & & $\begin{array}{l}-0.001 \\
(0.009)\end{array}$ & & $\begin{array}{l}-0.015 \\
(0.013)\end{array}$ & & $\begin{array}{c}0.038 \\
(0.033)\end{array}$ \\
\hline River Density & & $\begin{array}{l}-0.059 \\
(0.106)\end{array}$ & & $\begin{array}{c}-0.056 \\
(0.110)\end{array}$ & & $\begin{array}{l}-0.009 \\
(0.077)\end{array}$ & & $\begin{array}{c}0.074 \\
(0.065)\end{array}$ & & $\begin{array}{l}-0.058 \\
(0.094)\end{array}$ \\
\hline Share Desert & & $\begin{array}{c}0.591 \\
(0.737)\end{array}$ & & $\begin{array}{c}0.588 \\
(0.791)\end{array}$ & & $\begin{array}{c}-1.274 \\
(0.866)\end{array}$ & & $\begin{array}{c}0.296 \\
(0.767)\end{array}$ & & $\begin{array}{c}0.574 \\
(0.811)\end{array}$ \\
\hline Average Temperature & & $\begin{array}{l}-0.006 \\
(0.027)\end{array}$ & & $\begin{array}{c}0.021 \\
(0.025)\end{array}$ & & $\begin{array}{c}0.043 \\
(0.029)\end{array}$ & & $\begin{array}{c}0.024 \\
(0.024)\end{array}$ & & $\begin{array}{c}0.013 \\
(0.026)\end{array}$ \\
\hline Temperature Range & & $\begin{array}{c}0.144 \\
(0.096)\end{array}$ & & $\begin{array}{c}0.109 \\
(0.095)\end{array}$ & & $\begin{array}{c}0.077 \\
(0.110)\end{array}$ & & $\begin{array}{l}-0.053 \\
(0.098)\end{array}$ & & $\begin{array}{l}-0.130 \\
(0.084)\end{array}$ \\
\hline Soil Quality (Climatic) & Yes & Yes & Yes & Yes & Yes & Yes & Yes & Yes & Yes & Yes \\
\hline$N$ & 78 & 78 & 71 & 71 & 79 & 79 & 82 & 82 & 82 & 82 \\
\hline
\end{tabular}

This table presents the results of a series of ordered probit regression analyses, on the ethnic-group level, of measures of pre-colonial autocracy on a measure of pre-colonial jurisdictional hierarchy (the natural logarithm of the number of levels of jurisdictional hierarchy), conditional on a range of control variables at the ethnic-group level. Heteroscedasticity-consistent standard errors are reported in parentheses. ${ }^{* * *}$ Significant at the 1 percent level. ${ }^{* *}$ Significant at the 5 percent level. * Significant at the 10 percent level. 
Table B.7: Predicted Diversity and Autocratic Institutions — Ordered Probit

\begin{tabular}{|c|c|c|c|c|c|c|c|c|c|c|}
\hline & \multicolumn{2}{|c|}{$\begin{array}{l}\text { Degree of Absence } \\
\text { of Checks on } \\
\text { Leader's Power }\end{array}$} & \multicolumn{2}{|c|}{$\begin{array}{c}\text { Difficulty of } \\
\text { Removal of } \\
\text { Leaders }\end{array}$} & \multicolumn{2}{|c|}{$\begin{array}{l}\text { Leader's Exercise } \\
\text { of Authority }\end{array}$} & \multicolumn{2}{|c|}{$\begin{array}{l}\text { Degree of Lack of } \\
\text { Community } \\
\text { Decisions }\end{array}$} & \multicolumn{2}{|c|}{$\begin{array}{l}\text { Perception of } \\
\text { Leader's Power }\end{array}$} \\
\hline & (1) & $(2)$ & $(3)$ & (4) & $(5)$ & $(6)$ & $(7)$ & $(8)$ & (9) & $(10)$ \\
\hline Predicted Genetic Diversity & $\begin{array}{c}9.682^{* * *} \\
(3.164)\end{array}$ & $\begin{array}{l}8.573^{* *} \\
(3.704)\end{array}$ & $\begin{array}{c}9.660^{* * *} \\
(2.860)\end{array}$ & $\begin{array}{c}8.775^{* * *} \\
(2.998)\end{array}$ & $\begin{array}{c}10.106^{* * *} \\
(3.345)\end{array}$ & $\begin{array}{c}9.975^{* * *} \\
(3.406)\end{array}$ & $\begin{array}{c}12.557^{* * *} \\
(3.084)\end{array}$ & $\begin{array}{c}11.804^{* * *} \\
(3.161)\end{array}$ & $\begin{array}{c}10.392^{* * *} \\
(3.412)\end{array}$ & $\begin{array}{c}10.319^{* * *} \\
(3.768)\end{array}$ \\
\hline Log Absolute Latitude & $\begin{array}{c}0.062 \\
(0.141)\end{array}$ & $\begin{array}{c}-0.124 \\
(0.268)\end{array}$ & $\begin{array}{c}0.173 \\
(0.116)\end{array}$ & $\begin{array}{c}0.119 \\
(0.194)\end{array}$ & $\begin{array}{c}-0.085 \\
(0.139)\end{array}$ & $\begin{array}{c}-0.032 \\
(0.253)\end{array}$ & $\begin{array}{c}-0.218^{*} \\
(0.127)\end{array}$ & $\begin{array}{l}-0.128 \\
(0.208)\end{array}$ & $\begin{array}{c}0.049 \\
(0.137)\end{array}$ & $\begin{array}{c}0.117 \\
(0.202)\end{array}$ \\
\hline Elevation & & $\begin{array}{c}-0.000 \\
(0.001)\end{array}$ & & $\begin{array}{c}-0.001 \\
(0.000)\end{array}$ & & $\begin{array}{c}-0.000 \\
(0.001)\end{array}$ & & $\begin{array}{c}0.000 \\
(0.000)\end{array}$ & & $\begin{array}{c}0.000 \\
(0.000)\end{array}$ \\
\hline Terrain Ruggedness & & $\begin{array}{l}0.000^{* *} \\
(0.000)\end{array}$ & & $\begin{array}{c}0.000^{* * *} \\
(0.000)\end{array}$ & & $\begin{array}{c}0.000^{*} \\
(0.000)\end{array}$ & & $\begin{array}{c}0.000 \\
(0.000)\end{array}$ & & $\begin{array}{l}-0.000 \\
(0.000)\end{array}$ \\
\hline River Length & & $\begin{array}{c}0.021^{*} \\
(0.012)\end{array}$ & & $\begin{array}{c}0.001 \\
(0.013)\end{array}$ & & $\begin{array}{c}0.015 \\
(0.010)\end{array}$ & & $\begin{array}{c}0.001 \\
(0.010)\end{array}$ & & $\begin{array}{c}0.066^{*} \\
(0.035)\end{array}$ \\
\hline River Density & & $\begin{array}{c}-0.125 \\
(0.103)\end{array}$ & & $\begin{array}{l}-0.087 \\
(0.101)\end{array}$ & & $\begin{array}{c}-0.097 \\
(0.073)\end{array}$ & & $\begin{array}{l}-0.030 \\
(0.067)\end{array}$ & & $\begin{array}{c}-0.168 \\
(0.106)\end{array}$ \\
\hline Share Desert & & $\begin{array}{c}0.464 \\
(0.769)\end{array}$ & & $\begin{array}{c}0.335 \\
(0.794)\end{array}$ & & $\begin{array}{c}-1.219 \\
(0.898)\end{array}$ & & $\begin{array}{c}0.202 \\
(0.804)\end{array}$ & & $\begin{array}{c}0.709 \\
(0.842)\end{array}$ \\
\hline Average Temperature & & $\begin{array}{c}-0.004 \\
(0.030)\end{array}$ & & $\begin{array}{c}0.021 \\
(0.028)\end{array}$ & & $\begin{array}{c}0.039 \\
(0.030)\end{array}$ & & $\begin{array}{c}0.023 \\
(0.026)\end{array}$ & & $\begin{array}{c}0.008 \\
(0.027)\end{array}$ \\
\hline Temperature Range & & $\begin{array}{c}0.152 \\
(0.102)\end{array}$ & & $\begin{array}{l}0.149^{*} \\
(0.089)\end{array}$ & & $\begin{array}{c}0.099 \\
(0.103)\end{array}$ & & $\begin{array}{l}-0.037 \\
(0.084)\end{array}$ & & $\begin{array}{l}-0.109 \\
(0.089)\end{array}$ \\
\hline Soil Quality (Climatic) & Yes & Yes & Yes & Yes & Yes & Yes & Yes & Yes & Yes & Yes \\
\hline$N$ & 78 & 78 & 71 & 71 & 79 & 79 & 82 & 82 & 82 & 82 \\
\hline
\end{tabular}

This table presents the results of a series of ordered probit regression analyses, on the ethnic-group level, of measures of pre-colonial autocracy on predicted genetic diversity, based on the migratory distance from East Africa to the interior centroid of the homeland of the ethnicity, conditional on a range of control variables at the ethnic-group level. Heteroscedasticity-consistent standard errors are reported in parentheses. ${ }^{* * *}$ Significant at the 1 percent level. ${ }^{* *}$ Significant at the 5 percent level. ${ }^{*}$ Significant at the 10 percent level. 
Table B.8: Predicted Diversity and Jurisdictional Hierarchy — Accounting for Irrigation Potential

\begin{tabular}{|c|c|c|c|c|c|c|}
\hline & \multicolumn{6}{|c|}{ Log Number of Levels of Jurisdictional Hierarchy } \\
\hline & $(1)$ & $(2)$ & $(3)$ & (4) & (5) & (6) \\
\hline Predicted Genetic Diversity & $\begin{array}{c}5.348^{* * *} \\
(0.292)\end{array}$ & $\begin{array}{c}5.632^{* * *} \\
(0.319)\end{array}$ & $\begin{array}{c}5.723^{* * *} \\
(0.317)\end{array}$ & $\begin{array}{c}3.352^{* * *} \\
(0.994)\end{array}$ & $\begin{array}{c}3.315^{* * *} \\
(1.083)\end{array}$ & $\begin{array}{c}3.284^{* * *} \\
(1.089)\end{array}$ \\
\hline Log Percentage of Area Equipped for Irrigation & $\begin{array}{c}0.142^{* * *} \\
(0.018)\end{array}$ & $\begin{array}{c}0.127^{* * *} \\
(0.020)\end{array}$ & $\begin{array}{c}0.123^{* * *} \\
(0.021)\end{array}$ & $\begin{array}{c}0.158^{* * *} \\
(0.023)\end{array}$ & $\begin{array}{c}0.163^{* * *} \\
(0.023)\end{array}$ & $\begin{array}{c}0.168^{* * *} \\
(0.023)\end{array}$ \\
\hline Log Absolute Latitude & & $\begin{array}{l}0.032^{* *} \\
(0.015)\end{array}$ & $\begin{array}{c}0.040^{* *} \\
(0.016)\end{array}$ & $\begin{array}{c}0.085^{* * *} \\
(0.018)\end{array}$ & $\begin{array}{c}0.084^{* * *} \\
(0.019)\end{array}$ & $\begin{array}{c}0.101^{* * *} \\
(0.021)\end{array}$ \\
\hline Elevation & & & & & $\begin{array}{c}0.000 \\
(0.000)\end{array}$ & $\begin{array}{l}0.000^{* *} \\
(0.000)\end{array}$ \\
\hline Terrain Ruggedness & & & & & $\begin{array}{l}-0.000 \\
(0.000)\end{array}$ & $\begin{array}{c}-0.000^{* *} \\
(0.000)\end{array}$ \\
\hline River Length & & & & & $\begin{array}{c}0.003^{* * *} \\
(0.001)\end{array}$ & $\begin{array}{c}0.003^{* * *} \\
(0.001)\end{array}$ \\
\hline River Density & & & & & $\begin{array}{l}-0.003 \\
(0.002)\end{array}$ & $\begin{array}{l}-0.002 \\
(0.002)\end{array}$ \\
\hline Share Desert & & & & & $\begin{array}{l}-0.058 \\
(0.058)\end{array}$ & $\begin{array}{l}-0.000 \\
(0.069)\end{array}$ \\
\hline Average Temperature & & & & & & $\begin{array}{c}0.004 \\
(0.004)\end{array}$ \\
\hline Temperature Range & & & & & & $\begin{array}{c}-0.025^{* * *} \\
(0.008)\end{array}$ \\
\hline Soil Quality (Climatic) & No & No & Yes & Yes & Yes & Yes \\
\hline Continental FE & No & No & No & Yes & Yes & Yes \\
\hline$N$ & 1,076 & 1,076 & 1,076 & 1,076 & 1,076 & 1,076 \\
\hline Adjusted $R^{2}$ & 0.248 & 0.251 & 0.253 & 0.326 & 0.334 & 0.339 \\
\hline
\end{tabular}

This table presents the results of a series of OLS regression analyses, on the ethnic-group level, of a measure of pre-colonial jurisdictional hierarchy (the natural logarithm of the number of levels of jurisdictional hierarchy) on predicted genetic diversity, based on the migratory distance from East Africa to the interior centroid of the homeland of the ethnicity, conditional on a range of control variables including a measure of irrigation potential at the ethnic-group level. The irrigation measure is based on the "area equipped for irrigation" data of the Global Map of Irrigation Areas, version 5.0 (Siebert et al., 2013). Specifications marked with "Continental FE" accounts for sub-Saharan Africa, Latin America, and continental fixed effects. Heteroscedasticity-consistent standard errors are reported in parentheses. ${ }^{* * *}$ Significant at the 1 percent level. ${ }^{* *}$ Significant at the 5 percent level. ${ }^{*}$ Significant at the 10 percent level. 
Table B.9: Diversity and Jurisdictional Hierarchy — Accounting for Irrigation Potential

\begin{tabular}{|c|c|c|c|c|c|c|}
\hline & \multicolumn{6}{|c|}{ Log Number of Levels of Jurisdictional Hierarchy } \\
\hline & $(1)$ & (2) & (3) & (4) & (5) & (6) \\
\hline Genetic Diversity & $\begin{array}{c}3.285^{* * *} \\
(0.831)\end{array}$ & $\begin{array}{c}4.024^{* * *} \\
(0.854)\end{array}$ & $\begin{array}{c}4.239^{* * *} \\
(0.876)\end{array}$ & $\begin{array}{c}5.065^{*} \\
(2.700)\end{array}$ & $\begin{array}{c}6.375^{* *} \\
(3.096)\end{array}$ & $\begin{array}{l}7.021^{* *} \\
(3.105)\end{array}$ \\
\hline Log Percentage of Area Equipped for Irrigation & $\begin{array}{c}0.271^{* * *} \\
(0.027)\end{array}$ & $\begin{array}{c}0.232^{* * *} \\
(0.034)\end{array}$ & $\begin{array}{c}0.240^{* * *} \\
(0.039)\end{array}$ & $\begin{array}{c}0.209^{* *} \\
(0.084)\end{array}$ & $\begin{array}{c}0.302^{* * *} \\
(0.086)\end{array}$ & $\begin{array}{c}0.244^{* *} \\
(0.107)\end{array}$ \\
\hline Log Absolute Latitude & & $\begin{array}{c}0.083^{* *} \\
(0.033)\end{array}$ & $\begin{array}{l}0.075^{* *} \\
(0.037)\end{array}$ & $\begin{array}{c}0.093^{* * *} \\
(0.035)\end{array}$ & $\begin{array}{l}0.084^{* *} \\
(0.040)\end{array}$ & $\begin{array}{c}0.095^{* *} \\
(0.041)\end{array}$ \\
\hline Elevation & & & & & $\begin{array}{c}0.000 \\
(0.000)\end{array}$ & $\begin{array}{c}0.000 \\
(0.000)\end{array}$ \\
\hline Terrain Ruggedness & & & & & $\begin{array}{c}0.000 \\
(0.000)\end{array}$ & $\begin{array}{c}0.000 \\
(0.000)\end{array}$ \\
\hline River Length & & & & & $\begin{array}{c}0.003^{* * *} \\
(0.001)\end{array}$ & $\begin{array}{c}0.003^{* * *} \\
(0.001)\end{array}$ \\
\hline River Density & & & & & $\begin{array}{c}0.029 \\
(0.022)\end{array}$ & $\begin{array}{c}0.031 \\
(0.022)\end{array}$ \\
\hline Share Desert & & & & & $\begin{array}{l}-0.257 \\
(0.230)\end{array}$ & $\begin{array}{c}-0.379 \\
(0.251)\end{array}$ \\
\hline Average Temperature & & & & & & $\begin{array}{c}0.013 \\
(0.013)\end{array}$ \\
\hline Temperature Range & & & & & & $\begin{array}{c}0.002 \\
(0.025)\end{array}$ \\
\hline Soil Quality (Climatic) & No & No & Yes & Yes & Yes & Yes \\
\hline Continental FE & No & No & No & Yes & Yes & Yes \\
\hline$N$ & 131 & 131 & 131 & 131 & 131 & 131 \\
\hline Adjusted $R^{2}$ & 0.254 & 0.277 & 0.309 & 0.329 & 0.354 & 0.351 \\
\hline
\end{tabular}

This table presents the results of a series of OLS regression analyses, on the ethnic-group level, of a measure of pre-colonial jurisdictional hierarchy (the natural logarithm of the number of levels of jurisdictional hierarchy) on observed genetic diversity, conditional on a range of control variables including a measure of irrigation potential at the ethnic-group level. The irrigation measure is based on the "area equipped for irrigation" data of the Global Map of Irrigation Areas, version 5.0 (Siebert et al., 2013). Specifications marked with "Continental FE" accounts for sub-Saharan Africa, Latin America, and continental fixed effects. Heteroscedasticity-consistent standard errors are reported in parentheses. ${ }^{* * *}$ Significant at the 1 percent level. ${ }^{* *}$ Significant at the 5 percent level. $*$ Significant at the 10 percent level. 


\section{Table B.10: Predicted Diversity and Jurisdictional Hierarchy — Accounting for Irrigation Potential and its Interaction with Predicted Genetic Diversity}

\begin{tabular}{|c|c|c|c|c|c|}
\hline & \multicolumn{5}{|c|}{ Log Number of Levels of Jurisdictional Hierarchy } \\
\hline & (1) & (2) & (3) & (4) & (5) \\
\hline Predicted Genetic Diversity & $\begin{array}{c}4.221^{* * *} \\
(0.308)\end{array}$ & $\begin{array}{c}4.495^{* * *} \\
(0.326)\end{array}$ & $\begin{array}{c}4.581^{* * *} \\
(0.326)\end{array}$ & $\begin{array}{c}4.569^{* * *} \\
(0.334)\end{array}$ & $\begin{array}{c}4.567^{* * *} \\
(0.321)\end{array}$ \\
\hline Log Percentage of Area Equipped for Irrigation & $\begin{array}{c}-1.861^{* * *} \\
(0.280)\end{array}$ & $\begin{array}{c}-1.856^{* * *} \\
(0.280)\end{array}$ & $\begin{array}{c}-1.888^{* * *} \\
(0.281)\end{array}$ & $\begin{array}{c}-1.951^{* * *} \\
(0.284)\end{array}$ & $\begin{array}{c}-1.456^{* * *} \\
(0.298)\end{array}$ \\
\hline Log Percentage of Area Equipped for Irrigation $\times$ Predicted Genetic Diversity & $\begin{array}{c}2.835^{* * *} \\
(0.397)\end{array}$ & $\begin{array}{c}2.808^{* * *} \\
(0.396)\end{array}$ & $\begin{array}{c}2.844^{* * *} \\
(0.396)\end{array}$ & $\begin{array}{c}2.946^{* * *} \\
(0.400)\end{array}$ & $\begin{array}{c}2.251^{* * *} \\
(0.420)\end{array}$ \\
\hline Log Absolute Latitude & & $\begin{array}{l}0.030^{* *} \\
(0.015)\end{array}$ & $\begin{array}{l}0.039^{* *} \\
(0.016)\end{array}$ & $\begin{array}{c}0.045^{* * *} \\
(0.017)\end{array}$ & $\begin{array}{c}0.101^{* * *} \\
(0.021)\end{array}$ \\
\hline Elevation & & & & $\begin{array}{c}0.000 \\
(0.000)\end{array}$ & $\begin{array}{c}0.000^{* * *} \\
(0.000)\end{array}$ \\
\hline Terrain Ruggedness & & & & $\begin{array}{c}-0.000^{* * *} \\
(0.000)\end{array}$ & $\begin{array}{c}-0.000^{* * *} \\
(0.000)\end{array}$ \\
\hline River Length & & & & $\begin{array}{c}0.003^{* * *} \\
(0.001)\end{array}$ & $\begin{array}{c}0.003^{* * *} \\
(0.001)\end{array}$ \\
\hline River Density & & & & $\begin{array}{c}-0.000 \\
(0.001)\end{array}$ & $\begin{array}{c}0.000 \\
(0.001)\end{array}$ \\
\hline Share Desert & & & & $\begin{array}{c}0.001 \\
(0.060)\end{array}$ & $\begin{array}{c}0.017 \\
(0.063)\end{array}$ \\
\hline Average Temperature & & & & & $\begin{array}{c}0.011^{* * *} \\
(0.003)\end{array}$ \\
\hline Temperature Range & & & & & $\begin{array}{c}-0.033^{* * *} \\
(0.008) \\
\end{array}$ \\
\hline Soil Quality (Climatic) & No & No & Yes & Yes & Yes \\
\hline$N$ & 1,076 & 1,076 & 1,076 & 1,076 & 1,076 \\
\hline Adjusted $R^{2}$ & 0.273 & 0.275 & 0.278 & 0.294 & 0.310 \\
\hline
\end{tabular}


Table B.11: Predicted Diversity and Jurisdictional Hierarchy — Accounting for Ecological Diversity

\begin{tabular}{|c|c|c|c|c|c|c|}
\hline & \multicolumn{6}{|c|}{ Number of Levels of Jurisdictional Hierarchy } \\
\hline & $(1)$ & (2) & $(3)$ & (4) & $(5)$ & (6) \\
\hline Predicted Genetic Diversity & $\begin{array}{c}4.908^{* * *} \\
(0.294)\end{array}$ & $\begin{array}{c}5.554^{* * *} \\
(0.320)\end{array}$ & $\begin{array}{c}5.648^{* * *} \\
(0.318)\end{array}$ & $\begin{array}{c}4.905^{* * *} \\
(0.990)\end{array}$ & $\begin{array}{c}5.434^{* * *} \\
(1.072)\end{array}$ & $\begin{array}{c}5.755^{* * *} \\
(1.076)\end{array}$ \\
\hline Ecological diversity (FAO classes) & $\begin{array}{c}0.348^{* * *} \\
(0.068)\end{array}$ & $\begin{array}{c}0.354^{* * *} \\
(0.068)\end{array}$ & $\begin{array}{c}0.310^{* * *} \\
(0.072)\end{array}$ & $\begin{array}{c}0.298^{* * *} \\
(0.068)\end{array}$ & $\begin{array}{c}0.303^{* * *} \\
(0.069)\end{array}$ & $\begin{array}{c}0.311^{* * *} \\
(0.069)\end{array}$ \\
\hline Any diversity (FAO) & $\begin{array}{l}-0.014 \\
(0.052)\end{array}$ & $\begin{array}{l}-0.028 \\
(0.052)\end{array}$ & $\begin{array}{l}-0.020 \\
(0.054)\end{array}$ & $\begin{array}{c}0.053 \\
(0.052)\end{array}$ & $\begin{array}{c}0.042 \\
(0.052)\end{array}$ & $\begin{array}{c}0.047 \\
(0.052)\end{array}$ \\
\hline Log Absolute Latitude & & $\begin{array}{c}0.067^{* * *} \\
(0.013)\end{array}$ & $\begin{array}{c}0.076^{* * *} \\
(0.014)\end{array}$ & $\begin{array}{c}0.102^{* * *} \\
(0.018)\end{array}$ & $\begin{array}{c}0.098^{* * *} \\
(0.018)\end{array}$ & $\begin{array}{r}0.123^{* * *} \\
(0.020)\end{array}$ \\
\hline Elevation & & & & & $\begin{array}{c}-0.000 \\
(0.000)\end{array}$ & $\begin{array}{c}0.000 \\
(0.000)\end{array}$ \\
\hline Terrain Ruggedness & & & & & $\begin{array}{l}-0.000 \\
(0.000)\end{array}$ & $\begin{array}{c}-0.000^{*} \\
(0.000)\end{array}$ \\
\hline River Length & & & & & $\begin{array}{c}0.002^{* *} \\
(0.001)\end{array}$ & $\begin{array}{c}0.003^{* * *} \\
(0.001)\end{array}$ \\
\hline River Density & & & & & $\begin{array}{l}-0.003 \\
(0.002)\end{array}$ & $\begin{array}{c}-0.002 \\
(0.002)\end{array}$ \\
\hline Share Desert & & & & & $\begin{array}{c}0.068 \\
(0.065)\end{array}$ & $\begin{array}{c}0.049 \\
(0.073)\end{array}$ \\
\hline Average Temperature & & & & & & $\begin{array}{c}0.009^{* *} \\
(0.004)\end{array}$ \\
\hline Temperature Range & & & & & & $\begin{array}{c}-0.019^{* *} \\
(0.008) \\
\end{array}$ \\
\hline Soil Quality (Climatic) & No & No & Yes & Yes & Yes & Yes \\
\hline Continental FE & No & No & No & Yes & Yes & Yes \\
\hline $\mathrm{N}$ & 1,076 & 1,076 & 1,076 & 1,076 & 1,076 & 1,076 \\
\hline Adjusted $R^{2}$ & 0.223 & 0.241 & 0.242 & 0.311 & 0.316 & 0.321 \\
\hline $\begin{array}{l}\text { This table presents the results of a s } \\
\text { sure of pre-colonial jurisdictional hier } \\
\text { hierarchy) on predicted genetic diver } \\
\text { centroid of the homeland of the ethn } \\
\text { of ecological diversity at the ethnic } \\
\text { for sub-Saharan Africa, Latin Americ } \\
\text { errors are reported in parentheses. * } \\
\text { level. * Significant at the } 10 \text { percent }\end{array}$ & $\begin{array}{l}\text { es of OI } \\
\text { chy (the } \\
\text { y, based } \\
\text { ty, condi } \\
\text { roup lev } \\
\text { and cont } \\
\text { Signific }\end{array}$ & $\begin{array}{l}\text { gression } \\
\text { ural log. } \\
\text { he migr } \\
\text { al on a } \\
\text { pecifica } \\
\text { tal fixed } \\
\text { at the 1 }\end{array}$ & $\begin{array}{l}\text { alyses, o } \\
\text { hm of th } \\
y \text { distan } \\
\text { ge of con } \\
\text { is marke } \\
\text { ects. Het }\end{array}$ & $\begin{array}{l}\text { he ethnic- } \\
\text { umber of } \\
\text { from Eas } \\
\text { l variable } \\
\text { ith "Con } \\
\text { scedastici }\end{array}$ & $\begin{array}{l}\text { oup leve } \\
\text { vels of ju } \\
\text { Africa to } \\
\text { includin } \\
\text { nental Fl } \\
\text {-consiste }\end{array}$ & $\begin{array}{l}\text { of a mea- } \\
\text { sdictional } \\
\text { e interior } \\
\text { measure } \\
\text { accounts } \\
\text { standard }\end{array}$ \\
\hline
\end{tabular}


Table B.12: Diversity and Jurisdictional Hierarchy — Accounting for Ecological Diversity

\begin{tabular}{|c|c|c|c|c|c|c|}
\hline & \multicolumn{6}{|c|}{ Log Number of Levels of Jurisdictional Hierarchy } \\
\hline & (1) & $(2)$ & (3) & (4) & $(5)$ & (6) \\
\hline Genetic Diversity & $\begin{array}{l}2.380^{* *} \\
(0.963)\end{array}$ & $\begin{array}{c}3.894^{* * *} \\
(0.899)\end{array}$ & $\begin{array}{c}4.041^{* * *} \\
(0.999)\end{array}$ & $\begin{array}{c}7.657^{* * *} \\
(2.379)\end{array}$ & $\begin{array}{c}9.334^{* * *} \\
(3.194)\end{array}$ & $\begin{array}{c}9.247^{* * *} \\
(2.983)\end{array}$ \\
\hline Ecological diversity (FAO classes) & $\begin{array}{l}0.246 \\
(0.279)\end{array}$ & $\begin{array}{c}0.332 \\
(0.264)\end{array}$ & $\begin{array}{c}0.108 \\
(0.294)\end{array}$ & $\begin{array}{c}0.073 \\
(0.269)\end{array}$ & $\begin{array}{l}-0.006 \\
(0.291)\end{array}$ & $\begin{array}{c}0.119 \\
(0.292)\end{array}$ \\
\hline Any diversity (FAO) & $\begin{array}{l}0.382^{* *} \\
(0.175)\end{array}$ & $\begin{array}{l}0.471^{* *} \\
(0.220)\end{array}$ & $\begin{array}{l}0.588^{* *} \\
(0.267)\end{array}$ & $\begin{array}{c}0.179 \\
(0.197)\end{array}$ & $\begin{array}{c}0.132 \\
(0.296)\end{array}$ & $\begin{array}{c}0.135 \\
(0.303)\end{array}$ \\
\hline Log Absolute Latitude & & $\begin{array}{c}0.160^{* * *} \\
(0.030)\end{array}$ & $\begin{array}{c}0.156^{* * *} \\
(0.032)\end{array}$ & $\begin{array}{l}0.094^{* *} \\
(0.036)\end{array}$ & $\begin{array}{l}0.081^{*} \\
(0.044)\end{array}$ & $\begin{array}{l}0.099^{* *} \\
(0.043)\end{array}$ \\
\hline Elevation & & & & & $\begin{array}{l}-0.000 \\
(0.000)\end{array}$ & $\begin{array}{c}0.000 \\
(0.000)\end{array}$ \\
\hline Terrain Ruggedness & & & & & $\begin{array}{c}0.000 \\
(0.000)\end{array}$ & $\begin{array}{c}0.000 \\
(0.000)\end{array}$ \\
\hline River Length & & & & & $\begin{array}{c}0.001^{* * *} \\
(0.000)\end{array}$ & $\begin{array}{c}0.003^{* * *} \\
(0.001)\end{array}$ \\
\hline River Density & & & & & $\begin{array}{c}0.016 \\
(0.032)\end{array}$ & $\begin{array}{c}0.028 \\
(0.026)\end{array}$ \\
\hline Share Desert & & & & & $\begin{array}{l}-0.166 \\
(0.306)\end{array}$ & $\begin{array}{l}-0.481^{*} \\
(0.253)\end{array}$ \\
\hline Average Temperature & & & & & & $\begin{array}{l}0.028^{* *} \\
(0.011)\end{array}$ \\
\hline Temperature Range & & & & & & $\begin{array}{c}0.019 \\
(0.026)\end{array}$ \\
\hline Soil Quality (Climatic) & No & No & Yes & Yes & Yes & Yes \\
\hline Continental FE & No & No & No & Yes & Yes & Yes \\
\hline $\begin{array}{l}\mathrm{N} \\
\text { Adjusted } R^{2}\end{array}$ & $\begin{array}{c}131 \\
0.042\end{array}$ & $\begin{array}{c}131 \\
0.161\end{array}$ & $\begin{array}{c}131 \\
0.178\end{array}$ & $\begin{array}{c}131 \\
0.277\end{array}$ & $\begin{array}{c}131 \\
0.261\end{array}$ & $\begin{array}{c}131 \\
0.306\end{array}$ \\
\hline
\end{tabular}

This table presents the results of a series of OLS regression analyses, on the ethnic-group level, of a measure of pre-colonial jurisdictional hierarchy (the natural logarithm of the number of levels of jurisdictional hierarchy) on observed genetic diversity, conditional on a range of control variables including a measure of ecological diversity at the ethnic-group level. Specifications marked with "Continental FE" accounts for sub-Saharan Africa, Latin America, and continental fixed effects. Heteroscedasticity-consistent standard errors are reported in parentheses. *** Significant at the 1 percent level. ${ }^{* *}$ Significant at the 5 percent level. * Significant at the 10 percent level. 
Table B.13: Predicted Genetic Diversity and Jurisdictional Hierarchy — Accounting for Major Crop Type

\begin{tabular}{|c|c|c|c|c|c|c|}
\hline & \multicolumn{6}{|c|}{ Log Number of Levels of Jurisdictional Hierarchy } \\
\hline & (1) & $(2)$ & $(3)$ & $(4)$ & $(5)$ & $(6)$ \\
\hline Predicted Genetic Diversity & $\begin{array}{c}3.846^{* * *} \\
(0.356)\end{array}$ & $\begin{array}{c}4.833^{* * *} \\
(0.388)\end{array}$ & $\begin{array}{c}4.910^{* * *} \\
(0.385)\end{array}$ & $\begin{array}{c}5.923^{* * *} \\
(1.045)\end{array}$ & $\begin{array}{c}6.125^{* * *} \\
(1.113)\end{array}$ & $\begin{array}{c}5.903^{* * *} \\
(1.112)\end{array}$ \\
\hline Non Food Crops Only & $\begin{array}{c}0.694^{* * *} \\
(0.086)\end{array}$ & $\begin{array}{c}0.743^{* * *} \\
(0.138)\end{array}$ & $\begin{array}{c}0.705^{* * *} \\
(0.102)\end{array}$ & $\begin{array}{c}0.650^{* * *} \\
(0.058)\end{array}$ & $\begin{array}{c}0.647^{* * *} \\
(0.062)\end{array}$ & $\begin{array}{c}0.638^{* * *} \\
(0.063)\end{array}$ \\
\hline Vegetables & $\begin{array}{c}0.302^{* *} \\
(0.152)\end{array}$ & $\begin{array}{c}0.359^{* * *} \\
(0.107)\end{array}$ & $\begin{array}{c}0.385^{* * *} \\
(0.111)\end{array}$ & $\begin{array}{c}0.220^{*} \\
(0.122)\end{array}$ & $\begin{array}{c}0.237^{*} \\
(0.135)\end{array}$ & $\begin{array}{c}0.269^{* *} \\
(0.132)\end{array}$ \\
\hline Tree Fruits & $\begin{array}{c}0.198^{* * *} \\
(0.069)\end{array}$ & $\begin{array}{c}0.390^{* * *} \\
(0.073)\end{array}$ & $\begin{array}{c}0.394^{* * *} \\
(0.073)\end{array}$ & $\begin{array}{c}0.264^{* * *} \\
(0.079)\end{array}$ & $\begin{array}{c}0.262^{* * *} \\
(0.080)\end{array}$ & $\begin{array}{c}0.252^{* * *} \\
(0.081)\end{array}$ \\
\hline Roots or Tubers & $\begin{array}{c}0.186^{* * *} \\
(0.035)\end{array}$ & $\begin{array}{c}0.361^{* * *} \\
(0.046)\end{array}$ & $\begin{array}{c}0.361^{* * *} \\
(0.045)\end{array}$ & $\begin{array}{c}0.249^{* * *} \\
(0.060)\end{array}$ & $\begin{array}{c}0.249^{* * *} \\
(0.060)\end{array}$ & $\begin{array}{c}0.245^{* * *} \\
(0.063)\end{array}$ \\
\hline Cereal Grains & $\begin{array}{c}0.345^{* * *} \\
(0.036)\end{array}$ & $\begin{array}{c}0.405^{* * *} \\
(0.038)\end{array}$ & $\begin{array}{c}0.396^{* * *} \\
(0.038)\end{array}$ & $\begin{array}{c}0.301^{* * *} \\
(0.045)\end{array}$ & $\begin{array}{c}0.300^{* * *} \\
(0.046)\end{array}$ & $\begin{array}{c}0.315^{* * *} \\
(0.048)\end{array}$ \\
\hline Log Absolute Latitude & & $\begin{array}{c}0.112^{* * *} \\
(0.017)\end{array}$ & $\begin{array}{c}0.117^{* * *} \\
(0.017)\end{array}$ & $\begin{array}{c}0.108^{* * *} \\
(0.020)\end{array}$ & $\begin{array}{c}0.105^{* * *} \\
(0.020)\end{array}$ & $\begin{array}{c}0.111^{* * *} \\
(0.022)\end{array}$ \\
\hline Elevation & & & & & $\begin{array}{c}0.000 \\
(0.000)\end{array}$ & $\begin{array}{c}0.000 \\
(0.000)\end{array}$ \\
\hline Terrain Ruggedness & & & & & $\begin{array}{l}-0.000 \\
(0.000)\end{array}$ & $\begin{array}{c}-0.000^{*} \\
(0.000)\end{array}$ \\
\hline River Length & & & & & $\begin{array}{c}0.003^{* *} \\
(0.001)\end{array}$ & $\begin{array}{c}0.003^{* *} \\
(0.001)\end{array}$ \\
\hline River Density & & & & & $\begin{array}{c}-0.003 \\
(0.002)\end{array}$ & $\begin{array}{c}-0.003 \\
(0.002)\end{array}$ \\
\hline Share Desert & & & & & $\begin{array}{c}-0.040 \\
(0.059)\end{array}$ & $\begin{array}{c}0.044 \\
(0.071)\end{array}$ \\
\hline Average Temperature & & & & & & $\begin{array}{l}-0.000 \\
(0.004)\end{array}$ \\
\hline Temperature Range & & & & & & $\begin{array}{c}-0.021^{* *} \\
(0.008) \\
\end{array}$ \\
\hline Soil Quality (Climatic) & No & No & Yes & Yes & Yes & Yes \\
\hline Continental FE & No & No & No & Yes & Yes & Yes \\
\hline$N$ & 1,076 & 1,076 & 1,076 & 1,076 & 1,076 & 1,076 \\
\hline Adjusted $R^{2}$ & 0.254 & 0.291 & 0.292 & 0.317 & 0.323 & 0.326 \\
\hline
\end{tabular}

This table presents the results of a series of OLS regression analyses, on the ethnic-group level, of a measure of pre-colonial jurisdictional hierarchy (the natural logarithm of the number of levels of jurisdictional hierarchy) on predicted genetic diversity, based on the migratory distance from East Africa to the interior centroid of the homeland of the ethnicity, conditional on a range of control variables including major crop type fixed effects at the ethnic-group level. Specifications marked with "Continental FE" accounts for sub-Saharan Africa, Latin America, and continental fixed effects. Heteroscedasticity-consistent standard errors are reported in parentheses. $* * *$ Significant at the 1 percent level. ${ }^{* *}$ Significant at the 5 percent level. * Significant at the 10 percent level. 
Table B.14: Observed Genetic Diversity and Jurisdictional Hierarchy — Accounting for Major Crop Type

\begin{tabular}{|c|c|c|c|c|c|c|}
\hline & \multicolumn{6}{|c|}{ Log Number of Levels of Jurisdictional Hierarchy } \\
\hline & (1) & $(2)$ & $(3)$ & (4) & $(5)$ & (6) \\
\hline Genetic Diversity & $\begin{array}{c}2.190^{* *} \\
(0.972)\end{array}$ & $\begin{array}{c}3.631^{* * *} \\
(1.027)\end{array}$ & $\begin{array}{c}3.734^{* * *} \\
(1.002)\end{array}$ & $\begin{array}{c}7.543^{* * *} \\
(2.448)\end{array}$ & $\begin{array}{c}8.834^{\text {*** }} \\
(3.263)\end{array}$ & $\begin{array}{c}9.723^{* * *} \\
(2.983)\end{array}$ \\
\hline Tree Fruits & $\begin{array}{l}-0.117 \\
(0.326)\end{array}$ & $\begin{array}{c}-0.171 \\
(0.349)\end{array}$ & $\begin{array}{c}0.004 \\
(0.373)\end{array}$ & $\begin{array}{c}0.265 \\
(0.342)\end{array}$ & $\begin{array}{c}0.253 \\
(0.360)\end{array}$ & $\begin{array}{c}0.166 \\
(0.359)\end{array}$ \\
\hline Roots or Tubers & $\begin{array}{c}-0.016 \\
(0.169)\end{array}$ & $\begin{array}{c}-0.028 \\
(0.178)\end{array}$ & $\begin{array}{c}0.128 \\
(0.171)\end{array}$ & $\begin{array}{c}0.115 \\
(0.211)\end{array}$ & $\begin{array}{c}0.092 \\
(0.262)\end{array}$ & $\begin{array}{c}-0.041 \\
(0.240)\end{array}$ \\
\hline Cereal Grains & $\begin{array}{l}0.301^{* *} \\
(0.147)\end{array}$ & $\begin{array}{c}0.181 \\
(0.174)\end{array}$ & $\begin{array}{c}0.316^{* *} \\
(0.157)\end{array}$ & $\begin{array}{c}0.139 \\
(0.187)\end{array}$ & $\begin{array}{c}0.133 \\
(0.211)\end{array}$ & $\begin{array}{c}-0.026 \\
(0.191)\end{array}$ \\
\hline Log Absolute Latitude & & $\begin{array}{c}0.125^{* * *} \\
(0.033)\end{array}$ & $\begin{array}{c}0.116^{* * *} \\
(0.039)\end{array}$ & $\begin{array}{c}0.079^{*} \\
(0.045)\end{array}$ & $\begin{array}{c}0.069 \\
(0.048)\end{array}$ & $\begin{array}{c}0.103^{* *} \\
(0.051)\end{array}$ \\
\hline Elevation & & & & & $\begin{array}{l}-0.000 \\
(0.000)\end{array}$ & $\begin{array}{c}0.000 \\
(0.000)\end{array}$ \\
\hline Terrain Ruggedness & & & & & $\begin{array}{c}0.000 \\
(0.000)\end{array}$ & $\begin{array}{c}0.000 \\
(0.000)\end{array}$ \\
\hline River Length & & & & & $\begin{array}{c}0.001^{* * *} \\
(0.000)\end{array}$ & $\begin{array}{c}0.003^{* * *} \\
(0.001)\end{array}$ \\
\hline River Density & & & & & $\begin{array}{c}0.015 \\
(0.031)\end{array}$ & $\begin{array}{c}0.029 \\
(0.025)\end{array}$ \\
\hline Share Desert & & & & & $\begin{array}{l}-0.167 \\
(0.317)\end{array}$ & $\begin{array}{c}-0.509^{*} \\
(0.271)\end{array}$ \\
\hline Average Temperature & & & & & & $\begin{array}{c}0.028^{* *} \\
(0.012)\end{array}$ \\
\hline Temperature Range & & & & & & $\begin{array}{c}0.015 \\
(0.025) \\
\end{array}$ \\
\hline Soil Quality (Climatic) & No & No & Yes & Yes & Yes & Yes \\
\hline Continental FE & No & No & No & Yes & Yes & Yes \\
\hline$N$ & 131 & 131 & 131 & 131 & 131 & 131 \\
\hline Adjusted $R^{2}$ & 0.092 & 0.154 & 0.190 & 0.274 & 0.260 & 0.300 \\
\hline
\end{tabular}

This table presents the results of a series of OLS regression analyses, on the ethnic-group level, of a measure of pre-colonial jurisdictional hierarchy (the natural logarithm of the number of levels of jurisdictional hierarchy) on observed genetic diversity, conditional on a range of control variables including major crop type fixed effects at the ethnic-group level. Specifications marked with "Continental FE" accounts for sub-Saharan Africa, Latin America, and continental fixed effects. Heteroscedasticity-consistent standard errors are reported in parentheses. ${ }^{* * *}$ Significant at the 1 percent level. ** Significant at the 5 percent level. * Significant at the 10 percent level. 
Table B.15: Observed Diversity and Jurisdictional Hierarchy — Accounting for SD of Soil Suitability

\begin{tabular}{|c|c|c|c|c|c|c|}
\hline & \multicolumn{6}{|c|}{ Log Number of Levels of Jurisdictional Hierarchy } \\
\hline & $(1)$ & $(2)$ & $(3)$ & $(4)$ & $(5)$ & $(6)$ \\
\hline Predicted Genetic Diversity & $\begin{array}{c}5.062^{* * *} \\
(0.294)\end{array}$ & $\begin{array}{c}5.720^{* * *} \\
(0.323)\end{array}$ & $\begin{array}{c}5.719^{* * *} \\
(0.321)\end{array}$ & $\begin{array}{c}4.093^{* * *} \\
(1.060)\end{array}$ & $\begin{array}{c}4.694^{* * *} \\
(1.129)\end{array}$ & $\begin{array}{c}4.840^{* * *} \\
(1.125)\end{array}$ \\
\hline Log Absolute Latitude & & $\begin{array}{c}0.070^{* * *} \\
(0.014)\end{array}$ & $\begin{array}{c}0.069^{* * *} \\
(0.015)\end{array}$ & $\begin{array}{c}0.097^{* * *} \\
(0.018)\end{array}$ & $\begin{array}{c}0.097^{* * *} \\
(0.019)\end{array}$ & $\begin{array}{c}0.123^{* * *} \\
(0.021)\end{array}$ \\
\hline Elevation & & & & & $\begin{array}{c}-0.000 \\
(0.000)\end{array}$ & $\begin{array}{l}0.000^{* *} \\
(0.000)\end{array}$ \\
\hline Terrain Ruggedness & & & & & $\begin{array}{c}-0.000 \\
(0.000)\end{array}$ & $\begin{array}{c}-0.000^{* *} \\
(0.000)\end{array}$ \\
\hline River Length & & & & & $\begin{array}{c}0.002^{* *} \\
(0.001)\end{array}$ & $\begin{array}{c}0.003^{* * *} \\
(0.001)\end{array}$ \\
\hline River Density & & & & & $\begin{array}{c}-0.001 \\
(0.002)\end{array}$ & $\begin{array}{l}-0.001 \\
(0.002)\end{array}$ \\
\hline Share Desert & & & & & $\begin{array}{l}-0.005 \\
(0.065)\end{array}$ & $\begin{array}{l}-0.003 \\
(0.073)\end{array}$ \\
\hline Average Temperature & & & & & & $\begin{array}{l}0.009^{* *} \\
(0.004)\end{array}$ \\
\hline Temperature Range & & & & & & $\begin{array}{c}-0.026^{* * *} \\
(0.008)\end{array}$ \\
\hline Soil Suitability SD FE & Yes & Yes & Yes & Yes & Yes & Yes \\
\hline Soil Quality (Climatic) & No & No & Yes & Yes & Yes & Yes \\
\hline Continental FE & No & No & No & Yes & Yes & Yes \\
\hline$N$ & 1,076 & 1,076 & 1,076 & 1,076 & 1,076 & 1,076 \\
\hline Adjusted $R^{2}$ & 0.214 & 0.232 & 0.237 & 0.309 & 0.313 & 0.319 \\
\hline
\end{tabular}

This table presents the results of a series of OLS regression analyses, on the ethnic-group level, of a measure of pre-colonial jurisdictional hierarchy (the natural logarithm of the number of levels of jurisdictional hierarchy) on predicted genetic diversity, based on the migratory distance from East Africa to the interior centroid of the homeland of the ethnicity, conditional on a range of control variables including decile of standard deviation of soil suitability fixed effects at the ethnic-group level. Specifications marked with "Continental FE" accounts for sub-Saharan Africa, Latin America, and continental fixed effects. Heteroscedasticityconsistent standard errors are reported in parentheses. *** Significant at the 1 percent level. ${ }^{* *}$ Significant at the 5 percent level. * Significant at the 10 percent level. 
Table B.16: Observed Diversity and Jurisdictional Hierarchy — Accounting for SD of Soil Suitability

\begin{tabular}{|c|c|c|c|c|c|c|}
\hline & \multicolumn{6}{|c|}{ Log Number of Levels of Jurisdictional Hierarchy } \\
\hline & $(1)$ & $(2)$ & $(3)$ & $(4)$ & $(5)$ & (6) \\
\hline Genetic Diversity & $\begin{array}{c}2.623^{* * *} \\
(0.929)\end{array}$ & $\begin{array}{c}4.282^{\text {*** }} \\
(0.953)\end{array}$ & $\begin{array}{c}4.181^{* * *} \\
(1.016)\end{array}$ & $\begin{array}{l}6.313^{* *} \\
(2.416)\end{array}$ & $\begin{array}{l}7.673^{* *} \\
(2.975)\end{array}$ & $\begin{array}{c}7.655^{* * *} \\
(2.905)\end{array}$ \\
\hline Log Absolute Latitude & & $\begin{array}{c}0.158^{* * *} \\
(0.031)\end{array}$ & $\begin{array}{c}0.143^{* * *} \\
(0.034)\end{array}$ & $\begin{array}{l}0.084^{* *} \\
(0.038)\end{array}$ & $\begin{array}{c}0.053 \\
(0.044)\end{array}$ & $\begin{array}{c}0.082^{*} \\
(0.049)\end{array}$ \\
\hline Elevation & & & & & $\begin{array}{l}-0.000 \\
(0.000)\end{array}$ & $\begin{array}{c}0.000 \\
(0.000)\end{array}$ \\
\hline Terrain Ruggedness & & & & & $\begin{array}{c}0.000 \\
(0.000)\end{array}$ & $\begin{array}{c}0.000 \\
(0.000)\end{array}$ \\
\hline River Length & & & & & $\begin{array}{c}0.001 \\
(0.001)\end{array}$ & $\begin{array}{c}0.002^{\text {*** }} \\
(0.001)\end{array}$ \\
\hline River Density & & & & & $\begin{array}{l}-0.006 \\
(0.037)\end{array}$ & $\begin{array}{c}0.005 \\
(0.031)\end{array}$ \\
\hline Share Desert & & & & & $\begin{array}{c}-0.396 \\
(0.291)\end{array}$ & $\begin{array}{c}-0.751^{* * *} \\
(0.239)\end{array}$ \\
\hline Average Temperature & & & & & & $\begin{array}{c}0.030^{* * *} \\
(0.011)\end{array}$ \\
\hline Temperature Range & & & & & & $\begin{array}{l}-0.001 \\
(0.027) \\
\end{array}$ \\
\hline Soil Suitability SD FE & Yes & Yes & Yes & Yes & Yes & Yes \\
\hline Soil Quality (Climatic) & No & No & Yes & Yes & Yes & Yes \\
\hline Continental FE & No & No & No & Yes & Yes & Yes \\
\hline$N$ & 131 & 131 & 131 & 131 & 131 & 131 \\
\hline Adjusted $R^{2}$ & 0.095 & 0.205 & 0.230 & 0.321 & 0.311 & 0.359 \\
\hline
\end{tabular}

This table presents the results of a series of OLS regression analyses, on the ethnic-group level, of a measure of pre-colonial jurisdictional hierarchy (the natural logarithm of the number of levels of jurisdictional hierarchy) on observed genetic diversity, conditional on a range of control variables including decile of standard deviation of soil suitability fixed effects at the ethnic-group level. Specifications marked with "Continental FE" accounts for sub-Saharan Africa, Latin America, and continental fixed effects. Heteroscedasticity-consistent standard errors are reported in parentheses. *** Significant at the 1 percent level. ${ }^{* *}$ Significant at the 5 percent level. ${ }^{*}$ Significant at the 10 percent level. 
Table B.17: Predicted Genetic Diversity and Jurisdictional Hierarchy - Accounting for Scale

\begin{tabular}{|c|c|c|c|c|c|c|}
\hline & \multicolumn{6}{|c|}{ Log Number of Levels of Jurisdictional Hierarchy } \\
\hline & (1) & $(2)$ & (3) & $(4)$ & (5) & (6) \\
\hline Predicted Genetic Diversity & $\begin{array}{c}4.215^{* * *} \\
(0.286)\end{array}$ & $\begin{array}{c}4.493^{* * *} \\
(0.300)\end{array}$ & $\begin{array}{c}4.566^{* * *} \\
(0.304)\end{array}$ & $\begin{array}{c}3.531^{* * *} \\
(0.953)\end{array}$ & $\begin{array}{c}3.061^{* * *} \\
(1.037)\end{array}$ & $\begin{array}{c}3.071^{* * *} \\
(1.034)\end{array}$ \\
\hline Area & $\begin{array}{c}0.001 \\
(0.001)\end{array}$ & $\begin{array}{c}0.001 \\
(0.001)\end{array}$ & $\begin{array}{c}0.001 \\
(0.001)\end{array}$ & $\begin{array}{c}0.001 \\
(0.001)\end{array}$ & $\begin{array}{c}0.003^{* * *} \\
(0.001)\end{array}$ & $\begin{array}{c}0.003^{* * *} \\
(0.001)\end{array}$ \\
\hline Size of Local Community: Fewer than 50 & $\begin{array}{c}-0.180^{* * *} \\
(0.037)\end{array}$ & $\begin{array}{c}-0.183^{* * *} \\
(0.038)\end{array}$ & $\begin{array}{c}-0.171^{* * *} \\
(0.038)\end{array}$ & $\begin{array}{c}-0.145^{* * *} \\
(0.038)\end{array}$ & $\begin{array}{c}-0.161^{* * *} \\
(0.039)\end{array}$ & $\begin{array}{c}-0.162^{* * *} \\
(0.039)\end{array}$ \\
\hline Size of Local Community: 50-99 & $\begin{array}{c}-0.127^{* * *} \\
(0.042)\end{array}$ & $\begin{array}{c}-0.132^{* * *} \\
(0.041)\end{array}$ & $\begin{array}{c}-0.131^{* * *} \\
(0.042)\end{array}$ & $\begin{array}{c}-0.125^{* * *} \\
(0.040)\end{array}$ & $\begin{array}{c}-0.128^{* * *} \\
(0.040)\end{array}$ & $\begin{array}{c}-0.130^{* * * *} \\
(0.041)\end{array}$ \\
\hline Size of Local Community: 100-199 & $\begin{array}{l}-0.007 \\
(0.044)\end{array}$ & $\begin{array}{l}-0.004 \\
(0.044)\end{array}$ & $\begin{array}{c}0.000 \\
(0.045)\end{array}$ & $\begin{array}{c}0.011 \\
(0.044)\end{array}$ & $\begin{array}{c}0.003 \\
(0.044)\end{array}$ & $\begin{array}{l}-0.002 \\
(0.044)\end{array}$ \\
\hline Size of Local Community: 200-399 & $\begin{array}{l}-0.052 \\
(0.053)\end{array}$ & $\begin{array}{l}-0.054 \\
(0.053)\end{array}$ & $\begin{array}{l}-0.054 \\
(0.053)\end{array}$ & $\begin{array}{l}-0.040 \\
(0.052)\end{array}$ & $\begin{array}{l}-0.055 \\
(0.052)\end{array}$ & $\begin{array}{l}-0.054 \\
(0.052)\end{array}$ \\
\hline Size of Local Community: $400-1,000$ & $\begin{array}{c}0.069 \\
(0.057)\end{array}$ & $\begin{array}{c}0.064 \\
(0.056)\end{array}$ & $\begin{array}{c}0.052 \\
(0.057)\end{array}$ & $\begin{array}{c}0.047 \\
(0.058)\end{array}$ & $\begin{array}{c}0.043 \\
(0.060)\end{array}$ & $\begin{array}{c}0.041 \\
(0.060)\end{array}$ \\
\hline Size of Local Community: 1,000 w/o Towns over 5,000 & $\begin{array}{l}-0.110 \\
(0.129)\end{array}$ & $\begin{array}{l}-0.117 \\
(0.131)\end{array}$ & $\begin{array}{l}-0.107 \\
(0.129)\end{array}$ & $\begin{array}{l}-0.113 \\
(0.131)\end{array}$ & $\begin{array}{l}-0.125 \\
(0.132)\end{array}$ & $\begin{array}{l}-0.122 \\
(0.131)\end{array}$ \\
\hline Size of Local Community: Towns of 5,000-50,000 & $\begin{array}{c}0.597^{* * *} \\
(0.081)\end{array}$ & $\begin{array}{c}0.589^{* * *} \\
(0.082)\end{array}$ & $\begin{array}{c}0.591^{* * *} \\
(0.082)\end{array}$ & $\begin{array}{c}0.522^{* * *} \\
(0.087)\end{array}$ & $\begin{array}{c}0.519^{* * *} \\
(0.084)\end{array}$ & $\begin{array}{c}0.517^{* * *} \\
(0.083)\end{array}$ \\
\hline Size of Local Community: Cities of 50,000 or more & $\begin{array}{c}0.837^{* * *} \\
(0.033)\end{array}$ & $\begin{array}{c}0.813^{* * *} \\
(0.035)\end{array}$ & $\begin{array}{c}0.805^{* * *} \\
(0.037)\end{array}$ & $\begin{array}{c}0.769^{* * *} \\
(0.047)\end{array}$ & $\begin{array}{c}0.772^{* * *} \\
(0.049)\end{array}$ & $\begin{array}{c}0.770^{* * *} \\
(0.048)\end{array}$ \\
\hline Log Absolute Latitude & & $\begin{array}{l}0.029^{* *} \\
(0.012)\end{array}$ & $\begin{array}{l}0.033^{* *} \\
(0.013)\end{array}$ & $\begin{array}{c}0.071^{* * *} \\
(0.017)\end{array}$ & $\begin{array}{c}0.074^{* * *} \\
(0.018)\end{array}$ & $\begin{array}{c}0.085^{* * * *} \\
(0.020)\end{array}$ \\
\hline Elevation & & & & & $\begin{array}{l}0.000^{*} \\
(0.000)\end{array}$ & $\begin{array}{l}0.000^{* *} \\
(0.000)\end{array}$ \\
\hline Terrain Ruggedness & & & & & $\begin{array}{l}-0.000 \\
(0.000)\end{array}$ & $\begin{array}{c}-0.000^{* *} \\
(0.000)\end{array}$ \\
\hline River Length & & & & & $\begin{array}{c}-0.005^{* *} \\
(0.002)\end{array}$ & $\begin{array}{c}-0.005^{* *} \\
(0.002)\end{array}$ \\
\hline River Density & & & & & $\begin{array}{c}0.002 \\
(0.002)\end{array}$ & $\begin{array}{c}0.002 \\
(0.002)\end{array}$ \\
\hline Share Desert & & & & & $\begin{array}{c}0.019 \\
(0.055)\end{array}$ & $\begin{array}{c}0.064 \\
(0.067)\end{array}$ \\
\hline Average Temperature & & & & & & $\begin{array}{c}0.002 \\
(0.003)\end{array}$ \\
\hline Temperature Range & & & & & & $\begin{array}{c}-0.016^{* *} \\
(0.008)\end{array}$ \\
\hline Soil Quality (Climatic) & No & No & Yes & Yes & Yes & Yes \\
\hline Continental FE & No & No & No & Yes & Yes & Yes \\
\hline$N$ & 1,076 & 1,076 & 1,076 & 1,076 & 1,076 & 1,076 \\
\hline Adjusted $R^{2}$ & 0.403 & 0.405 & 0.406 & 0.425 & 0.429 & 0.430 \\
\hline $\begin{array}{l}\text { This table presents the results of a series of OLS regression a } \\
\text { hierarchy (the natural logarithm of the number of levels of ju } \\
\text { distance from East Africa to the interior centroid of the hom } \\
\text { ethnicity-homeland area and mean size of local communit } \\
\text { "Continental FE" accounts for sub-Saharan Africa, Latin Ar } \\
\text { errors are reported in parentheses. }{ }^{* * *} \text { Significant at the } 1 \\
\text { percent level. }\end{array}$ & $\begin{array}{l}\text { lyses, on } t \\
\text { dictional } 1 \\
\text { and of the } \\
\text { fixed eff } \\
\text { rica, and } \\
\text { rcent leve }\end{array}$ & $\begin{array}{l}\text { ethnic-grc } \\
\text { archy) on } \\
\text { hnicity, co } \\
\text { s at th } \\
\text { tinental fi } \\
\text { ** Signific }\end{array}$ & $\begin{array}{l}\text { level, of } \\
\text { dicted ge } \\
\text { tional on } \\
\text { thnic-gro } \\
\text { effects. } \\
\text { at the } 5\end{array}$ & $\begin{array}{l}\text { easure of } \\
\text { ic diversit } \\
\text { ange of cc } \\
\text { level. Sp } \\
\text { eroscedas }\end{array}$ & $\begin{array}{l}\text { e-colonial j } \\
\text { based on } t \\
\text { rol variabl } \\
\text { ifications } \\
\text { ity-consist } \\
\text { * Significa }\end{array}$ & $\begin{array}{l}\text { isdictional } \\
\text { migratory } \\
\text { including } \\
\text { arked with } \\
\text { t standard } \\
\text { tat the } 10\end{array}$ \\
\hline
\end{tabular}


Table B.18: Observed Genetic Diversity and Jurisdictional Hierarchy - Accounting for Scale

\begin{tabular}{|c|c|c|c|c|c|c|}
\hline & \multicolumn{6}{|c|}{ Log Number of Levels of Jurisdictional Hierarchy } \\
\hline & (1) & $(2)$ & $(3)$ & $(4)$ & $(5)$ & $(6)$ \\
\hline Genetic Diversity & $\begin{array}{c}2.899^{* * *} \\
(0.723)\end{array}$ & $\begin{array}{c}3.845^{* * *} \\
(0.800)\end{array}$ & $\begin{array}{c}3.819^{* * *} \\
(0.914)\end{array}$ & $\begin{array}{l}3.778^{*} \\
(2.189)\end{array}$ & $\begin{array}{l}5.399^{*} \\
(2.873)\end{array}$ & $\begin{array}{l}5.689^{* *} \\
(2.852)\end{array}$ \\
\hline Area & $\begin{array}{c}0.000 \\
(0.000)\end{array}$ & $\begin{array}{c}0.000 \\
(0.000)\end{array}$ & $\begin{array}{l}0.000^{* *} \\
(0.000)\end{array}$ & $\begin{array}{l}0.000^{* *} \\
(0.000)\end{array}$ & $\begin{array}{l}0.005^{* *} \\
(0.002)\end{array}$ & $\begin{array}{l}0.004^{* *} \\
(0.002)\end{array}$ \\
\hline Size of Local Community: Fewer than 50 & $\begin{array}{c}0.020 \\
(0.155)\end{array}$ & $\begin{array}{c}0.094 \\
(0.163)\end{array}$ & $\begin{array}{l}-0.002 \\
(0.155)\end{array}$ & $\begin{array}{l}-0.013 \\
(0.151)\end{array}$ & $\begin{array}{c}0.051 \\
(0.138)\end{array}$ & $\begin{array}{c}0.082 \\
(0.140)\end{array}$ \\
\hline Size of Local Community: 50-99 & $\begin{array}{l}-0.121 \\
(0.142)\end{array}$ & $\begin{array}{l}-0.114 \\
(0.133)\end{array}$ & $\begin{array}{c}0.001 \\
(0.145)\end{array}$ & $\begin{array}{c}0.039 \\
(0.140)\end{array}$ & $\begin{array}{c}0.039 \\
(0.162)\end{array}$ & $\begin{array}{c}0.077 \\
(0.158)\end{array}$ \\
\hline Size of Local Community: 100-199 & $\begin{array}{c}0.087 \\
(0.120)\end{array}$ & $\begin{array}{c}0.141 \\
(0.119)\end{array}$ & $\begin{array}{c}0.133 \\
(0.129)\end{array}$ & $\begin{array}{c}0.122 \\
(0.150)\end{array}$ & $\begin{array}{c}0.050 \\
(0.145)\end{array}$ & $\begin{array}{c}0.042 \\
(0.152)\end{array}$ \\
\hline Size of Local Community: 200-399 & $\begin{array}{l}-0.143 \\
(0.176)\end{array}$ & $\begin{array}{l}-0.133 \\
(0.155)\end{array}$ & $\begin{array}{l}-0.108 \\
(0.162)\end{array}$ & $\begin{array}{l}-0.114 \\
(0.195)\end{array}$ & $\begin{array}{l}-0.230 \\
(0.200)\end{array}$ & $\begin{array}{l}-0.237 \\
(0.185)\end{array}$ \\
\hline Size of Local Community: $400-1,000$ & $\begin{array}{c}0.218^{*} \\
(0.119)\end{array}$ & $\begin{array}{c}0.163 \\
(0.118)\end{array}$ & $\begin{array}{c}0.233^{*} \\
(0.132)\end{array}$ & $\begin{array}{c}0.195 \\
(0.135)\end{array}$ & $\begin{array}{c}0.223 \\
(0.156)\end{array}$ & $\begin{array}{c}0.233 \\
(0.153)\end{array}$ \\
\hline Size of Local Community: 1,000 w/o Towns over 5,000 & $\begin{array}{c}-0.559^{* * *} \\
(0.075)\end{array}$ & $\begin{array}{c}-0.557^{* * *} \\
(0.073)\end{array}$ & $\begin{array}{c}-0.576^{* * *} \\
(0.106)\end{array}$ & $\begin{array}{c}-0.572^{* * *} \\
(0.110)\end{array}$ & $\begin{array}{c}-0.645^{* * *} \\
(0.108)\end{array}$ & $\begin{array}{c}-0.695^{* * *} \\
(0.124)\end{array}$ \\
\hline Size of Local Community: Towns of $5,000-50,000$ & $\begin{array}{c}0.682^{* * *} \\
(0.238)\end{array}$ & $\begin{array}{c}0.661^{* *} \\
(0.256)\end{array}$ & $\begin{array}{c}0.628^{* *} \\
(0.255)\end{array}$ & $\begin{array}{c}0.857^{* * *} \\
(0.133)\end{array}$ & $\begin{array}{c}0.897^{* * *} \\
(0.131)\end{array}$ & $\begin{array}{c}0.922^{* * *} \\
(0.134)\end{array}$ \\
\hline Size of Local Community: Cities of 50,000 or more & $\begin{array}{c}0.887^{* * *} \\
(0.084)\end{array}$ & $\begin{array}{c}0.825^{* * *} \\
(0.088)\end{array}$ & $\begin{array}{c}0.826^{* * *} \\
(0.102)\end{array}$ & $\begin{array}{c}0.760^{* * *} \\
(0.109)\end{array}$ & $\begin{array}{c}0.814^{* * *} \\
(0.119)\end{array}$ & $\begin{array}{c}0.779^{* * *} \\
(0.128)\end{array}$ \\
\hline Log Absolute Latitude & & $\begin{array}{l}0.082^{* *} \\
(0.034)\end{array}$ & $\begin{array}{c}0.054 \\
(0.038)\end{array}$ & $\begin{array}{c}0.061 \\
(0.043)\end{array}$ & $\begin{array}{l}0.082^{*} \\
(0.042)\end{array}$ & $\begin{array}{c}0.071 \\
(0.046)\end{array}$ \\
\hline Elevation & & & & & $\begin{array}{c}0.000 \\
(0.000)\end{array}$ & $\begin{array}{l}-0.000 \\
(0.000)\end{array}$ \\
\hline Terrain Ruggedness & & & & & $\begin{array}{c}0.000 \\
(0.000)\end{array}$ & $\begin{array}{l}0.000^{*} \\
(0.000)\end{array}$ \\
\hline River Length & & & & & $\begin{array}{c}-0.012^{* *} \\
(0.005)\end{array}$ & $\begin{array}{c}-0.010^{* *} \\
(0.005)\end{array}$ \\
\hline River Density & & & & & $\begin{array}{c}0.065^{* * *} \\
(0.024)\end{array}$ & $\begin{array}{c}0.067^{* * *} \\
(0.024)\end{array}$ \\
\hline Share Desert & & & & & $\begin{array}{l}-0.076 \\
(0.233)\end{array}$ & $\begin{array}{l}-0.254 \\
(0.245)\end{array}$ \\
\hline Average Temperature & & & & & & $\begin{array}{c}0.006 \\
(0.010)\end{array}$ \\
\hline Temperature Range & & & & & & $\begin{array}{c}0.033 \\
(0.022)\end{array}$ \\
\hline Soil Quality (Climatic) & No & No & Yes & Yes & Yes & Yes \\
\hline Continental FE & No & No & No & Yes & Yes & Yes \\
\hline$N$ & 131 & 131 & 131 & 131 & 131 & 131 \\
\hline Adjusted $R^{2}$ & 0.387 & 0.411 & 0.427 & 0.503 & 0.522 & 0.526 \\
\hline $\begin{array}{l}\text { This table presents the results of a series of OLS regress } \\
\text { jurisdictional hierarchy (the natural logarithm of the num } \\
\text { conditional on a range of control variables including ethnic } \\
\text { the ethnic-group level. Specifications marked with "Continen } \\
\text { fixed effects. Heteroscedasticity-consistent standard errors }\end{array}$ & $\begin{array}{l}\text { analyses } \\
\text { of levels } \\
\text { homelan } \\
\text { FE" acco } \\
\text { reported }\end{array}$ & $\begin{array}{l}\mathrm{n} \text { the et } \\
\text { jurisdict } \\
\text { ea and } \mathrm{n} \\
\mathrm{s} \text { for sub- } \\
\text { parenthe }\end{array}$ & $\begin{array}{l}\text { group l } \\
\text { l hierarc } \\
\text { size of } 1 \\
\text { aran Afr } \\
* * * \text { Sig }\end{array}$ & $\begin{array}{l}\text { of a } \mathrm{m} \\
\text { on obse } \\
\text { l commu } \\
\text { Latin An } \\
\text { cant at } \mathrm{t}\end{array}$ & $\begin{array}{l}\text { ure of } p \\
\text { genetic } \\
\text { es fixed } \\
\text { ca, and } \\
\text { percen }\end{array}$ & $\begin{array}{l}\text { olonial } \\
\text { rersity, } \\
\text { ts at } \\
\text { nental } \\
\text { el. ** }\end{array}$ \\
\hline
\end{tabular}


Table B.19: Predicted Genetic Diversity and Jurisdictional Hierarchy — Excluding Africa

\begin{tabular}{|c|c|c|c|c|c|c|}
\hline & \multicolumn{6}{|c|}{ Log Number of Levels of Jurisdictional Hierarchy } \\
\hline & $(1)$ & $(2)$ & $(3)$ & $(4)$ & $(5)$ & $(6)$ \\
\hline Predicted Genetic Diversity & $\begin{array}{c}6.525^{* * *} \\
(0.548)\end{array}$ & $\begin{array}{c}6.520^{* * *} \\
(0.564)\end{array}$ & $\begin{array}{c}6.538^{* * *} \\
(0.569)\end{array}$ & $\begin{array}{c}6.524^{* * *} \\
(1.215)\end{array}$ & $\begin{array}{c}\text { 7.791*** } \\
(1.297)\end{array}$ & $\begin{array}{c}7.791^{* * *} \\
(1.290)\end{array}$ \\
\hline Log Absolute Latitude & & $\begin{array}{c}0.001 \\
(0.020)\end{array}$ & $\begin{array}{c}0.024 \\
(0.022)\end{array}$ & $\begin{array}{c}0.104^{* * *} \\
(0.033)\end{array}$ & $\begin{array}{c}0.099^{* * *} \\
(0.033)\end{array}$ & $\begin{array}{r}0.156^{* * *} \\
(0.045)\end{array}$ \\
\hline Elevation & & & & & $\begin{array}{c}0.000 \\
(0.000)\end{array}$ & $\begin{array}{l}0.000^{*} \\
(0.000)\end{array}$ \\
\hline Terrain Ruggedness & & & & & $\begin{array}{c}-0.000^{* * *} \\
(0.000)\end{array}$ & $\begin{array}{c}-0.000^{* * *} \\
(0.000)\end{array}$ \\
\hline River Length & & & & & $\begin{array}{l}0.002^{* *} \\
(0.001)\end{array}$ & $\begin{array}{c}0.003^{* * *} \\
(0.001)\end{array}$ \\
\hline River Density & & & & & $\begin{array}{l}-0.003 \\
(0.002)\end{array}$ & $\begin{array}{l}-0.003 \\
(0.002)\end{array}$ \\
\hline Share Desert & & & & & $\begin{array}{l}-0.037 \\
(0.074)\end{array}$ & $\begin{array}{l}-0.065 \\
(0.084)\end{array}$ \\
\hline Average Temperature & & & & & & $\begin{array}{l}0.012^{* *} \\
(0.005)\end{array}$ \\
\hline Temperature Range & & & & & & $\begin{array}{c}-0.022^{* *} \\
(0.011)\end{array}$ \\
\hline Soil Quality (Climatic) & No & No & Yes & Yes & Yes & Yes \\
\hline Continental FE & No & No & No & Yes & Yes & Yes \\
\hline$N$ & 590 & 590 & 590 & 590 & 590 & 590 \\
\hline Adjusted $R^{2}$ & 0.219 & 0.217 & 0.256 & 0.331 & 0.353 & 0.361 \\
\hline
\end{tabular}

This table presents the results of a series of OLS regression analyses, on the ethnic-group level, of a measure of pre-colonial jurisdictional hierarchy (the natural logarithm of the number of levels of jurisdictional hierarchy) on predicted genetic diversity, based on the migratory distance from East Africa to the interior centroid of the homeland of the ethnicity, conditional on a range of control variables and excluding observations from Africa at the ethnic-group level. Specifications marked with "Continental FE" accounts for sub-Saharan Africa, Latin America, and continental fixed effects. Heteroscedasticity-consistent standard errors are reported in parentheses. *** Significant at the 1 percent level. ${ }^{* *}$ Significant at the 5 percent level. * Significant at the 10 percent level. 
Table B.20: Genetic Diversity and Jurisdictional Hierarchy — Excluding Africa

\begin{tabular}{|c|c|c|c|c|c|c|}
\hline & \multicolumn{6}{|c|}{ Log Number of Levels of Jurisdictional Hierarchy } \\
\hline & $(1)$ & $(2)$ & $(3)$ & $(4)$ & $(5)$ & $(6)$ \\
\hline Genetic Diversity & $\begin{array}{c}8.694^{* * *} \\
(1.186)\end{array}$ & $\begin{array}{c}8.581^{* * *} \\
(1.477)\end{array}$ & $\begin{array}{c}10.082^{* * *} \\
(1.352)\end{array}$ & $\begin{array}{c}10.082^{\text {*** }} \\
(1.352)\end{array}$ & $\begin{array}{c}8.511^{* * *} \\
(2.539)\end{array}$ & $\begin{array}{c}9.199^{* * *} \\
(2.286)\end{array}$ \\
\hline Log Absolute Latitude & & $\begin{array}{c}0.013 \\
(0.106)\end{array}$ & $\begin{array}{l}-0.173 \\
(0.128)\end{array}$ & $\begin{array}{l}-0.173 \\
(0.128)\end{array}$ & $\begin{array}{l}-0.227 \\
(0.135)\end{array}$ & $\begin{array}{c}0.088 \\
(0.276)\end{array}$ \\
\hline Elevation & & & & & $\begin{array}{l}0.000^{*} \\
(0.000)\end{array}$ & $\begin{array}{c}0.000 \\
(0.000)\end{array}$ \\
\hline Terrain Ruggedness & & & & & $\begin{array}{c}-0.000^{* *} \\
(0.000)\end{array}$ & $\begin{array}{l}-0.000 \\
(0.000)\end{array}$ \\
\hline River Length & & & & & $\begin{array}{c}0.002^{* *} \\
(0.001)\end{array}$ & $\begin{array}{c}0.003^{* * *} \\
(0.001)\end{array}$ \\
\hline River Density & & & & & $\begin{array}{l}-0.008 \\
(0.025)\end{array}$ & $\begin{array}{c}0.017 \\
(0.027)\end{array}$ \\
\hline Share Desert & & & & & $\begin{array}{c}0.247 \\
(0.495)\end{array}$ & $\begin{array}{c}-0.424 \\
(0.541)\end{array}$ \\
\hline Average Temperature & & & & & & $\begin{array}{c}0.033 \\
(0.022)\end{array}$ \\
\hline Temperature Range & & & & & & $\begin{array}{c}0.020 \\
(0.046)\end{array}$ \\
\hline Soil Quality (Climatic) & No & No & Yes & Yes & Yes & Yes \\
\hline$N$ & 54 & 54 & 54 & 54 & 54 & 54 \\
\hline Adjusted $R^{2}$ & 0.356 & 0.343 & 0.330 & 0.330 & 0.385 & 0.432 \\
\hline
\end{tabular}

This table presents the results of a series of OLS regression analyses, on the ethnic-group level, of a measure of pre-colonial jurisdictional hierarchy (the natural logarithm of the number of levels of jurisdictional hierarchy) on observed genetic diversity, conditional on a range of control variables and excluding observations from Africa at the ethnic-group level. Heteroscedasticity-consistent standard errors are reported in parentheses. ${ }^{* * *}$ Significant at the 1 percent level. ${ }^{* *}$ Significant at the 5 percent level. * Significant at the 10 percent level.

Given the low number of observations when excluding Africa and focusing on the sample of observed genetic diversity, this robustness table is generated without inclusion of continental dummies. Table B.19 establishes that the results are robust to accounting for continental fixed effects when excluding Africa in the larger sample of predicted genetic diversity. 
Table B.21: Predicted Genetic Diversity and Jurisdictional Hierarchy — Accounting for Year in Ethnographic Atlas

\begin{tabular}{|c|c|c|c|c|c|c|}
\hline & \multicolumn{6}{|c|}{ Log Number of Levels of Jurisdictional Hierarchy } \\
\hline & $(1)$ & $(2)$ & $(3)$ & $(4)$ & $(5)$ & $(6)$ \\
\hline Predicted Genetic Diversity & $\begin{array}{c}5.223^{* * *} \\
(0.288)\end{array}$ & $\begin{array}{c}5.810^{* * *} \\
(0.316)\end{array}$ & $\begin{array}{c}5.879^{* * *} \\
(0.313)\end{array}$ & $\begin{array}{c}5.300^{* * *} \\
(1.009)\end{array}$ & $\begin{array}{c}5.422^{* * *} \\
(1.100)\end{array}$ & $\begin{array}{c}5.644^{* * *} \\
(1.105)\end{array}$ \\
\hline Year in Ethnographic Atlas & $\begin{array}{c}-0.000^{* * *} \\
(0.000)\end{array}$ & $\begin{array}{c}-0.000^{* *} \\
(0.000)\end{array}$ & $\begin{array}{c}-0.000^{* *} \\
(0.000)\end{array}$ & $\begin{array}{c}-0.000^{* *} \\
(0.000)\end{array}$ & $\begin{array}{c}-0.000^{* *} \\
(0.000)\end{array}$ & $\begin{array}{c}-0.000^{* *} \\
(0.000)\end{array}$ \\
\hline Log Absolute Latitude & & $\begin{array}{c}0.064^{* * *} \\
(0.014)\end{array}$ & $\begin{array}{c}0.075^{* * *} \\
(0.015)\end{array}$ & $\begin{array}{c}0.107^{* * *} \\
(0.018)\end{array}$ & $\begin{array}{c}0.105^{* * *} \\
(0.019)\end{array}$ & $\begin{array}{c}0.127^{* * *} \\
(0.021)\end{array}$ \\
\hline Elevation & & & & & $\begin{array}{c}0.000 \\
(0.000)\end{array}$ & $\begin{array}{c}0.000^{* *} \\
(0.000)\end{array}$ \\
\hline Terrain Ruggedness & & & & & $\begin{array}{c}-0.000^{*} \\
(0.000)\end{array}$ & $\begin{array}{c}-0.000^{* * *} \\
(0.000)\end{array}$ \\
\hline River Length & & & & & $\begin{array}{c}0.003^{* * *} \\
(0.001)\end{array}$ & $\begin{array}{c}0.003^{* * *} \\
(0.001)\end{array}$ \\
\hline River Density & & & & & $\begin{array}{c}-0.003 \\
(0.002)\end{array}$ & $\begin{array}{c}-0.002 \\
(0.002)\end{array}$ \\
\hline Share Desert & & & & & $\begin{array}{c}0.005 \\
(0.062)\end{array}$ & $\begin{array}{c}0.009 \\
(0.072)\end{array}$ \\
\hline Average Temperature & & & & & & $\begin{array}{l}0.007^{*} \\
(0.004)\end{array}$ \\
\hline Temperature Range & & & & & & $\begin{array}{c}-0.020^{* *} \\
(0.008)\end{array}$ \\
\hline Soil Quality (Climatic) & No & No & Yes & Yes & Yes & Yes \\
\hline Continental FE & No & No & No & Yes & Yes & Yes \\
\hline$N$ & 1,075 & 1,075 & 1,075 & 1,075 & 1,075 & 1,075 \\
\hline Adjusted $R^{2}$ & 0.204 & 0.220 & 0.228 & 0.295 & 0.302 & 0.305 \\
\hline
\end{tabular}

This table presents the results of a series of OLS regression analyses, on the ethnic-group level, of a measure of pre-colonial jurisdictional hierarchy (the natural logarithm of the number of levels of jurisdictional hierarchy) on predicted genetic diversity, based on the migratory distance from East Africa to the interior centroid of the homeland of the ethnicity, conditional on a range of control variables including the approximate year of description as reported in the Ethnographic Atlas at the ethnic-group level. Specifications marked with "Continental FE" accounts for sub-Saharan Africa, Latin America, and continental fixed effects. Heteroscedasticity-consistent standard errors are reported in parentheses. ${ }^{* * *}$ Significant at the 1 percent level. ** Significant at the 5 percent level. * Significant at the 10 percent level. 
Table B.22: Genetic Diversity and Jurisdictional Hierarchy - Accounting for Year in Ethnographic Atlas

\begin{tabular}{|c|c|c|c|c|}
\hline & \multicolumn{4}{|c|}{ Log Levels of Jurisdictional Hierarchy } \\
\hline & (1) & $(2)$ & $(3)$ & $(4)$ \\
\hline Genetic Diversity & $\begin{array}{l}1.940^{*} \\
(1.089)\end{array}$ & $\begin{array}{c}7.620^{* * *} \\
(2.551)\end{array}$ & $\begin{array}{l}7.222^{* *} \\
(3.140)\end{array}$ & $\begin{array}{l}7.328^{* *} \\
(3.068)\end{array}$ \\
\hline Year in Ethnographic Atlas & $\begin{array}{l}-0.001 \\
(0.001)\end{array}$ & $\begin{array}{l}-0.000 \\
(0.001)\end{array}$ & $\begin{array}{c}-0.001 \\
(0.001)\end{array}$ & $\begin{array}{c}-0.002 \\
(0.001)\end{array}$ \\
\hline Log Absolute Latitude & & $\begin{array}{l}-0.009 \\
(0.027)\end{array}$ & $\begin{array}{c}0.054 \\
(0.033)\end{array}$ & $\begin{array}{c}0.095^{* * *} \\
(0.027)\end{array}$ \\
\hline Elevation & & & $\begin{array}{c}0.000^{* * *} \\
(0.000)\end{array}$ & $\begin{array}{c}0.000^{* * *} \\
(0.000)\end{array}$ \\
\hline Terrain Ruggedness & & & $\begin{array}{c}-0.000 \\
(0.000)\end{array}$ & $\begin{array}{c}-0.000 \\
(0.000)\end{array}$ \\
\hline River Length & & & $\begin{array}{c}0.000 \\
(0.000)\end{array}$ & $\begin{array}{c}0.002^{* * *} \\
(0.001)\end{array}$ \\
\hline River Density & & & $\begin{array}{c}-0.057 \\
(0.083)\end{array}$ & $\begin{array}{c}-0.065 \\
(0.075)\end{array}$ \\
\hline Share Desert & & & $\begin{array}{c}0.295^{*} \\
(0.172)\end{array}$ & $\begin{array}{c}0.337 \\
(0.226)\end{array}$ \\
\hline Average Temperature & & & & $\begin{array}{c}0.023^{* *} \\
(0.011)\end{array}$ \\
\hline Temperature Range & & & & $\begin{array}{l}-0.040 \\
(0.027)\end{array}$ \\
\hline Soil Quality (Climatic) & No & Yes & Yes & Yes \\
\hline Continental FE & No & Yes & Yes & Yes \\
\hline $\begin{array}{l}N \\
\text { Adjusted } R^{2}\end{array}$ & $\begin{array}{c}94 \\
0.029\end{array}$ & $\begin{array}{c}94 \\
0.085\end{array}$ & $\begin{array}{c}94 \\
0.150\end{array}$ & $\begin{array}{c}94 \\
0.202\end{array}$ \\
\hline
\end{tabular}

This table presents the results of a series of OLS regression analyses, on the ethnicgroup level, of a measure of pre-colonial jurisdictional hierarchy (the natural logarithm of the number of levels of jurisdictional hierarchy) on observed genetic diversity, conditional on a range of control variables including the approximate year of description as reported in the Ethnographic Atlas at the ethnic-group level. Specifications marked with "Continental FE" accounts for sub-Saharan Africa, Latin America, and continental fixed effects. Heteroscedasticity-consistent standard errors are reported in parentheses. $* * *$ Significant at the 1 percent level. ** Significant at the 5 percent level. * Significant at the 10 percent level. 
Table B.23: Predicted Diversity and Jurisdictional Hierarchy — Levels Specification

\begin{tabular}{|c|c|c|c|c|c|c|}
\hline & \multicolumn{6}{|c|}{ Number of Levels of Jurisdictional Hierarchy } \\
\hline & (1) & $(2)$ & $(3)$ & $(4)$ & $(5)$ & (6) \\
\hline Predicted Genetic Diversity & $\begin{array}{c}9.357^{* * *} \\
(0.600)\end{array}$ & $\begin{array}{c}10.779^{* * *} \\
(0.684)\end{array}$ & $\begin{array}{c}10.879^{* * *} \\
(0.673)\end{array}$ & $\begin{array}{c}11.149^{* * *} \\
(2.144)\end{array}$ & $\begin{array}{c}11.390^{* * *} \\
(2.369)\end{array}$ & $\begin{array}{c}11.810^{* * *} \\
(2.417)\end{array}$ \\
\hline Log Absolute Latitude & & $\begin{array}{c}0.149^{* * *} \\
(0.028)\end{array}$ & $\begin{array}{c}0.175^{* * *} \\
(0.030)\end{array}$ & $\begin{array}{c}0.214^{* * *} \\
(0.037)\end{array}$ & $\begin{array}{c}0.209^{* * *} \\
(0.038)\end{array}$ & $\begin{array}{c}0.250^{* * *} \\
(0.043)\end{array}$ \\
\hline Elevation & & & & & $\begin{array}{c}0.000 \\
(0.000)\end{array}$ & $\begin{array}{l}0.000^{*} \\
(0.000)\end{array}$ \\
\hline Terrain Ruggedness & & & & & $\begin{array}{c}-0.000^{*} \\
(0.000)\end{array}$ & $\begin{array}{c}-0.000^{* *} \\
(0.000)\end{array}$ \\
\hline River Length & & & & & $\begin{array}{c}0.007^{* * *} \\
(0.003)\end{array}$ & $\begin{array}{c}0.008^{* * *} \\
(0.003)\end{array}$ \\
\hline River Density & & & & & $\begin{array}{c}-0.010^{*} \\
(0.005)\end{array}$ & $\begin{array}{c}-0.009^{*} \\
(0.005)\end{array}$ \\
\hline Share desert & & & & & $\begin{array}{c}0.012 \\
(0.132)\end{array}$ & $\begin{array}{c}0.027 \\
(0.156)\end{array}$ \\
\hline Average Temperature & & & & & & $\begin{array}{c}0.013 \\
(0.008)\end{array}$ \\
\hline Temperature Range & & & & & & $\begin{array}{c}-0.039^{* *} \\
(0.017)\end{array}$ \\
\hline Soil Quality (Climatic) & No & No & Yes & Yes & Yes & Yes \\
\hline Continental FE & No & No & No & Yes & Yes & Yes \\
\hline$N$ & 1,076 & 1,076 & 1,076 & 1,076 & 1,076 & 1,076 \\
\hline Adjusted $R^{2}$ & 0.158 & 0.179 & 0.185 & 0.269 & 0.285 & 0.287 \\
\hline
\end{tabular}

This table presents the results of a series of OLS regression analyses, on the ethnic-group level, of a measure of precolonial jurisdictional hierarchy (the number of levels of jurisdictional hierarchy) on predicted genetic diversity, based on the migratory distance from East Africa to the interior centroid of the homeland of the ethnicity, conditional on a range of control variables at the ethnic-group level. Specifications marked with "Continental FE" accounts for sub-Saharan Africa, Latin America, and continental fixed effects. Heteroscedasticity-consistent standard errors are reported in parentheses. *** Significant at the 1 percent level. ** Significant at the 5 percent level. * Significant at the 10 percent level. 
Table B.24: Diversity and Jurisdictional Hierarchy — Levels Specification

\begin{tabular}{|c|c|c|c|c|c|c|}
\hline & \multicolumn{6}{|c|}{ Number of Levels of Jurisdictional Hierarchy } \\
\hline & (1) & $(2)$ & $(3)$ & (4) & $(5)$ & $(6)$ \\
\hline Genetic Diversity & $\begin{array}{l}4.308^{* *} \\
(2.065)\end{array}$ & $\begin{array}{c}7.595^{* * *} \\
(2.021)\end{array}$ & $\begin{array}{c}8.109^{* * *} \\
(1.919)\end{array}$ & $\begin{array}{c}17.567^{\text {*** }} \\
(5.280)\end{array}$ & $\begin{array}{c}19.777^{* * *} \\
(6.844)\end{array}$ & $\begin{array}{c}20.081^{\text {*** }} \\
(6.335)\end{array}$ \\
\hline Log Absolute Latitude & & $\begin{array}{r}0.329^{* * *} \\
(0.069)\end{array}$ & $\begin{array}{c}0.337^{* * *} \\
(0.080)\end{array}$ & $\begin{array}{c}0.181^{* *} \\
(0.076)\end{array}$ & $\begin{array}{c}0.140 \\
(0.089)\end{array}$ & $\begin{array}{c}0.191^{* *} \\
(0.093)\end{array}$ \\
\hline Elevation & & & & & $\begin{array}{l}-0.000 \\
(0.000)\end{array}$ & $\begin{array}{c}0.000 \\
(0.000)\end{array}$ \\
\hline Terrain Ruggedness & & & & & $\begin{array}{c}0.000 \\
(0.000)\end{array}$ & $\begin{array}{c}0.000 \\
(0.000)\end{array}$ \\
\hline River Length & & & & & $\begin{array}{c}0.004^{* * *} \\
(0.001)\end{array}$ & $\begin{array}{c}0.007^{* * *} \\
(0.002)\end{array}$ \\
\hline River Density & & & & & $\begin{array}{c}0.009 \\
(0.071)\end{array}$ & $\begin{array}{c}0.034 \\
(0.055)\end{array}$ \\
\hline Share desert & & & & & $\begin{array}{l}-0.499 \\
(0.677)\end{array}$ & $\begin{array}{c}-1.284^{* *} \\
(0.588)\end{array}$ \\
\hline Average Temperature & & & & & & $\begin{array}{l}0.069^{* *} \\
(0.026)\end{array}$ \\
\hline Temperature Range & & & & & & $\begin{array}{c}0.026 \\
(0.053) \\
\end{array}$ \\
\hline Soil Quality (Climatic) & No & No & Yes & Yes & Yes & Yes \\
\hline Continental FE & No & No & No & Yes & Yes & Yes \\
\hline$N$ & 131 & 131 & 131 & 131 & 131 & 131 \\
\hline Adjusted $R^{2}$ & 0.017 & 0.120 & 0.129 & 0.249 & 0.249 & 0.304 \\
\hline
\end{tabular}

This table presents the results of a series of OLS regression analyses, on the ethnic-group level, of a measure of pre-colonial jurisdictional hierarchy (the number of levels of jurisdictional hierarchy) on observed genetic diversity, conditional on a range of control variables at the ethnic-group level. Specifications marked with "Continental FE" accounts for sub-Saharan Africa, Latin America, and continental fixed effects. Heteroscedasticity-consistent standard errors are reported in parentheses. *** Significant at the 1 percent level. ${ }^{* *}$ Significant at the 5 percent level. ${ }^{*}$ Significant at the 10 percent level. 
Table B.25: Predicted Diversity and Jurisdictional Hierarchy - Accounting for Irrigation Potential with Predicted Genetic Diversity

\begin{tabular}{|c|c|c|c|c|c|c|c|c|c|c|}
\hline & \multicolumn{2}{|c|}{$\begin{array}{l}\text { Degree of Absence } \\
\text { of Checks on } \\
\text { Leader's Power }\end{array}$} & \multicolumn{2}{|c|}{$\begin{array}{l}\text { Difficulty of } \\
\text { Removal of } \\
\text { Leaders }\end{array}$} & \multicolumn{2}{|c|}{$\begin{array}{c}\text { Leader's Exercise } \\
\text { of Authority }\end{array}$} & \multicolumn{2}{|c|}{$\begin{array}{c}\text { Degree of Lack of } \\
\text { Community } \\
\text { Decisions }\end{array}$} & \multicolumn{2}{|c|}{$\begin{array}{l}\text { Perception of } \\
\text { Leader's Power }\end{array}$} \\
\hline & (1) & $(2)$ & $(3)$ & (4) & $(5)$ & $(6)$ & $(7)$ & $(8)$ & (9) & $(10)$ \\
\hline Predicted Genetic Diversity & $\begin{array}{c}5.688^{* * * *} \\
(2.091)\end{array}$ & $\begin{array}{l}4.914^{* *} \\
(2.320)\end{array}$ & $\begin{array}{l}5.413^{* *} \\
(2.055)\end{array}$ & $\begin{array}{l}4.813^{* *} \\
(2.114)\end{array}$ & $\begin{array}{c}5.413^{* * * *} \\
(1.999)\end{array}$ & $\begin{array}{l}5.143^{* *} \\
(2.028)\end{array}$ & $\begin{array}{c}6.447^{* * * *} \\
(1.563)\end{array}$ & $\begin{array}{c}5.988^{* * * *} \\
(1.702)\end{array}$ & $\begin{array}{c}5.363^{* * * *} \\
(1.799)\end{array}$ & $\begin{array}{l}5.418^{* *} \\
(2.114)\end{array}$ \\
\hline Log Percentage of Area Equipped for Irrigation & $\begin{array}{c}0.237^{* * *} \\
(0.088)\end{array}$ & $\begin{array}{l}0.180^{*} \\
(0.092)\end{array}$ & $\begin{array}{c}0.480^{* * *} \\
(0.123)\end{array}$ & $\begin{array}{c}0.383^{\text {*** }} \\
(0.125)\end{array}$ & $\begin{array}{c}0.151 \\
(0.107)\end{array}$ & $\begin{array}{c}0.121 \\
(0.118)\end{array}$ & $\begin{array}{c}0.041 \\
(0.082)\end{array}$ & $\begin{array}{c}0.017 \\
(0.085)\end{array}$ & $\begin{array}{c}0.048 \\
(0.102)\end{array}$ & $\begin{array}{c}0.042 \\
(0.108)\end{array}$ \\
\hline Log Absolute Latitude & $\begin{array}{c}-0.032 \\
(0.098)\end{array}$ & $\begin{array}{l}-0.109 \\
(0.184)\end{array}$ & $\begin{array}{c}0.000 \\
(0.099)\end{array}$ & $\begin{array}{c}0.077 \\
(0.145)\end{array}$ & $\begin{array}{l}-0.098 \\
(0.095)\end{array}$ & $\begin{array}{l}-0.052 \\
(0.175)\end{array}$ & $\begin{array}{l}-0.113 \\
(0.072)\end{array}$ & $\begin{array}{l}-0.047 \\
(0.124)\end{array}$ & $\begin{array}{c}0.011 \\
(0.088)\end{array}$ & $\begin{array}{c}0.082 \\
(0.146)\end{array}$ \\
\hline Elevation & & $\begin{array}{l}-0.000 \\
(0.000)\end{array}$ & & $\begin{array}{l}-0.000 \\
(0.000)\end{array}$ & & $\begin{array}{l}-0.000 \\
(0.000)\end{array}$ & & $\begin{array}{c}0.000 \\
(0.000)\end{array}$ & & $\begin{array}{c}0.000 \\
(0.000)\end{array}$ \\
\hline Terrain Ruggedness & & $\begin{array}{c}0.000 \\
(0.000)\end{array}$ & & $\begin{array}{c}0.000 \\
(0.000)\end{array}$ & & $\begin{array}{c}0.000 \\
(0.000)\end{array}$ & & $\begin{array}{c}0.000 \\
(0.000)\end{array}$ & & $\begin{array}{l}-0.000 \\
(0.000)\end{array}$ \\
\hline Average Temperature & & $\begin{array}{l}-0.003 \\
(0.020)\end{array}$ & & $\begin{array}{c}0.020 \\
(0.020)\end{array}$ & & $\begin{array}{c}0.020 \\
(0.019)\end{array}$ & & $\begin{array}{c}0.015 \\
(0.015)\end{array}$ & & $\begin{array}{c}0.011 \\
(0.016)\end{array}$ \\
\hline Temperature Range & & $\begin{array}{c}0.094 \\
(0.068)\end{array}$ & & $\begin{array}{c}0.060 \\
(0.068)\end{array}$ & & $\begin{array}{c}0.058 \\
(0.062)\end{array}$ & & $\begin{array}{l}-0.013 \\
(0.049)\end{array}$ & & $\begin{array}{l}-0.048 \\
(0.054)\end{array}$ \\
\hline River Length & & $\begin{array}{c}0.011 \\
(0.008)\end{array}$ & & $\begin{array}{l}-0.004 \\
(0.009)\end{array}$ & & $\begin{array}{c}0.007 \\
(0.007)\end{array}$ & & $\begin{array}{c}0.001 \\
(0.007)\end{array}$ & & $\begin{array}{l}0.013^{*} \\
(0.007)\end{array}$ \\
\hline River Density & & $\begin{array}{l}-0.064 \\
(0.050)\end{array}$ & & $\begin{array}{l}-0.028 \\
(0.034)\end{array}$ & & $\begin{array}{l}-0.044 \\
(0.035)\end{array}$ & & $\begin{array}{l}-0.017 \\
(0.041)\end{array}$ & & $\begin{array}{l}-0.044 \\
(0.032)\end{array}$ \\
\hline Share Desert & & $\begin{array}{c}0.012 \\
(0.562)\end{array}$ & & $\begin{array}{l}-0.191 \\
(0.597)\end{array}$ & & $\begin{array}{l}-0.663 \\
(0.545)\end{array}$ & & $\begin{array}{c}0.057 \\
(0.488)\end{array}$ & & $\begin{array}{c}0.087 \\
(0.483)\end{array}$ \\
\hline Soil Quality (Climatic) & Yes & Yes & Yes & Yes & Yes & Yes & Yes & Yes & Yes & Yes \\
\hline$N$ & 78 & 78 & 71 & 71 & 79 & 79 & 82 & 82 & 82 & 82 \\
\hline Adjusted R2 & 0.118 & 0.132 & 0.228 & 0.248 & 0.132 & 0.110 & 0.189 & 0.132 & 0.154 & 0.096 \\
\hline
\end{tabular}


Table B.26: Observed Genetic Diversity and Indigenous Autocracy

\begin{tabular}{lcccc}
\hline & \multicolumn{3}{c}{ Indigenous Autocracy } \\
\cline { 2 - 5 } & $(1)$ & $(2)$ & $(3)$ & $(4)$ \\
\hline Genetic Diversity & $1.866^{*}$ & $7.627^{* * *}$ & $7.338^{* *}$ & $7.591^{* *}$ \\
Log Absolute Latitude & $(1.070)$ & $(2.517)$ & $(3.105)$ & $(3.089)$ \\
& & -0.008 & $0.055^{*}$ & $0.093^{* * *}$ \\
Elevation & $(0.027)$ & $(0.033)$ & $(0.027)$ \\
& & & $0.000^{* * *}$ & $0.000^{* * *}$ \\
Terrain Ruggedness & & & $(0.000)$ & $(0.000)$ \\
& & & -0.000 & -0.000 \\
River Length & & & $0.000)$ & $(0.000)$ \\
& & & $(0.000)$ & $0.001^{* *}$ \\
River Density & & & -0.059 & $-0.067)$ \\
& & & $0.081)$ & $(0.073)$ \\
Share Desert & & & $(0.169)$ & $(0.224)$ \\
Average Temperature & & & & $0.019^{*}$ \\
Temperature Range & & & & $(0.011)$ \\
& & & & -0.038 \\
& & & & $(0.027)$ \\
\hline Soil Quality (Climatic) & No & Yes & Yes & Yes \\
Continental FE & No & Yes & Yes & Yes \\
\hline$N$ & 94 & 94 & 94 & 94 \\
Adjusted $R^{2}$ & 0.032 & 0.097 & 0.159 & 0.197 \\
\hline
\end{tabular}

This table presents the results of a series of OLS regression analyses, on the ethnic-group level, of a measure of pre-colonial autocracy on observed genetic diversity, conditional on a range of control variables. Specifications marked with "Continental FE" accounts for sub-Saharan Africa, Latin America, and continental fixed effects. Heteroscedasticity-consistent standard errors are reported in parentheses. $* * *$ Significant at the 1 percent level. $* *$ Significant at the 5 percent level. $*$ Significant at the 10 percent level. 
Table B.27: Persistence of Institutions — Old and New World

\begin{tabular}{|c|c|c|c|c|c|c|c|c|c|c|c|c|}
\hline & \multicolumn{6}{|c|}{ Executive Constraints } & \multicolumn{6}{|c|}{ Autocracy } \\
\hline & $(1)$ & $(2)$ & (3) & $(4)$ & $(5)$ & $(6)$ & & & & & & \\
\hline Degree of Absence of Checks on Leader's Power & $\begin{array}{c}-0.186^{* * *} \\
(0.052)\end{array}$ & $\begin{array}{c}-0.093^{*} \\
(0.050)\end{array}$ & $\begin{array}{c}-0.084 \\
(0.052)\end{array}$ & & & & $\begin{array}{c}0.519^{* * *} \\
(0.108)\end{array}$ & $\begin{array}{l}0.343^{* *} \\
(0.131)\end{array}$ & $\begin{array}{l}0.315^{* *} \\
(0.138)\end{array}$ & & & \\
\hline $\begin{array}{l}\text { Degree of Absence of Checks on Leader's Power } \\
\quad \text { (Ancestry Adjusted) }\end{array}$ & & & & $\begin{array}{c}-0.191^{* * *} \\
(0.054)\end{array}$ & $\begin{array}{l}-0.105^{*} \\
(0.057)\end{array}$ & $\begin{array}{c}-0.111^{*} \\
(0.056)\end{array}$ & & & & $\begin{array}{c}0.553^{* * *} \\
(0.118)\end{array}$ & $\begin{array}{c}0.372^{* *} \\
(0.150)\end{array}$ & $\begin{array}{l}0.386^{* *} \\
(0.147)\end{array}$ \\
\hline Predicted Genetic Diversity & & & $\begin{array}{c}-1.981^{* *} \\
(0.902)\end{array}$ & & & & & & $\begin{array}{c}6.069^{* * *} \\
(2.164)\end{array}$ & & & \\
\hline $\begin{array}{l}\text { Predicted Genetic Diversity } \\
\text { (Ancestry Adjusted) }\end{array}$ & & & & & & $\begin{array}{l}-3.705^{*} \\
(1.915)\end{array}$ & & & & & & $\begin{array}{l}9.729^{* *} \\
(4.609)\end{array}$ \\
\hline Log Absolute Latitude & & $\begin{array}{l}-0.067 \\
(0.045)\end{array}$ & $\begin{array}{c}-0.074 \\
(0.045)\end{array}$ & & $\begin{array}{l}-0.076 \\
(0.046)\end{array}$ & $\begin{array}{c}-0.084^{*} \\
(0.048)\end{array}$ & & $\begin{array}{c}0.089 \\
(0.122)\end{array}$ & $\begin{array}{l}0.110 \\
(0.107)\end{array}$ & & $\begin{array}{c}0.121 \\
(0.125)\end{array}$ & $\begin{array}{c}0.141 \\
(0.115)\end{array}$ \\
\hline Soil Fertility & & $\begin{array}{c}0.294 \\
(0.376)\end{array}$ & $\begin{array}{c}0.194 \\
(0.385)\end{array}$ & & $\begin{array}{c}0.270 \\
(0.371)\end{array}$ & $\begin{array}{c}0.124 \\
(0.390)\end{array}$ & & $\begin{array}{l}-1.016 \\
(0.945)\end{array}$ & $\begin{array}{l}-0.709 \\
(0.910)\end{array}$ & & $\begin{array}{l}-0.955 \\
(0.957)\end{array}$ & $\begin{array}{l}-0.571 \\
(0.927)\end{array}$ \\
\hline Roughness & & $\begin{array}{c}0.264 \\
(0.449)\end{array}$ & $\begin{array}{l}-0.048 \\
(0.448)\end{array}$ & & $\begin{array}{c}0.173 \\
(0.451)\end{array}$ & $\begin{array}{l}-0.446 \\
(0.565)\end{array}$ & & $\begin{array}{l}-0.523 \\
(1.162)\end{array}$ & $\begin{array}{c}0.431 \\
(1.146)\end{array}$ & & $\begin{array}{c}-0.186 \\
(1.196)\end{array}$ & $\begin{array}{c}1.441 \\
(1.473)\end{array}$ \\
\hline Elevation & & $\begin{array}{c}-0.206^{* *} \\
(0.096)\end{array}$ & $\begin{array}{l}-0.167 \\
(0.103)\end{array}$ & & $\begin{array}{l}-0.195^{*} \\
(0.103)\end{array}$ & $\begin{array}{l}-0.106 \\
(0.117)\end{array}$ & & $\begin{array}{l}0.558^{*} \\
(0.285)\end{array}$ & $\begin{array}{c}0.440 \\
(0.313)\end{array}$ & & $\begin{array}{l}0.525^{*} \\
(0.305)\end{array}$ & $\begin{array}{c}0.292 \\
(0.360)\end{array}$ \\
\hline Average Distance to Nearest Waterway & & $\begin{array}{c}-0.302^{* * *} \\
(0.107)\end{array}$ & $\begin{array}{c}-0.259^{* *} \\
(0.109)\end{array}$ & & $\begin{array}{c}-0.322^{* * *} \\
(0.107)\end{array}$ & $\begin{array}{c}-0.312^{* * *} \\
(0.105)\end{array}$ & & $\begin{array}{c}0.323 \\
(0.270)\end{array}$ & $\begin{array}{c}0.190 \\
(0.287)\end{array}$ & & $\begin{array}{l}0.398 \\
(0.277)\end{array}$ & $\begin{array}{c}0.372 \\
(0.275)\end{array}$ \\
\hline Percentage of Arable Land & & $\begin{array}{c}0.004 \\
(0.004)\end{array}$ & $\begin{array}{c}0.005 \\
(0.004)\end{array}$ & & $\begin{array}{c}0.004 \\
(0.004)\end{array}$ & $\begin{array}{c}0.005 \\
(0.004)\end{array}$ & & $\begin{array}{l}-0.001 \\
(0.009)\end{array}$ & $\begin{array}{l}-0.006 \\
(0.009)\end{array}$ & & $\begin{array}{l}-0.001 \\
(0.009)\end{array}$ & $\begin{array}{l}-0.004 \\
(0.009)\end{array}$ \\
\hline Temperature & & $\begin{array}{c}-0.024^{* * *} \\
(0.007)\end{array}$ & $\begin{array}{c}-0.020^{* * *} \\
(0.007)\end{array}$ & & $\begin{array}{c}-0.026^{* * *} \\
(0.007)\end{array}$ & $\begin{array}{c}-0.025^{* * *} \\
(0.007)\end{array}$ & & $\begin{array}{l}0.030^{*} \\
(0.017)\end{array}$ & $\begin{array}{c}0.018 \\
(0.017)\end{array}$ & & $\begin{array}{l}0.036^{* *} \\
(0.017)\end{array}$ & $\begin{array}{l}0.032^{*} \\
(0.016)\end{array}$ \\
\hline Colony & & $\begin{array}{c}0.192 \\
(0.119)\end{array}$ & $\begin{array}{c}0.103 \\
(0.137)\end{array}$ & & $\begin{array}{c}0.198 \\
(0.119)\end{array}$ & $\begin{array}{c}0.139 \\
(0.132)\end{array}$ & & $\begin{array}{l}-0.421^{*} \\
(0.229)\end{array}$ & $\begin{array}{l}-0.148 \\
(0.273)\end{array}$ & & $\begin{array}{l}-0.442^{*} \\
(0.230)\end{array}$ & $\begin{array}{l}-0.290 \\
(0.263)\end{array}$ \\
\hline$N$ & 47 & 47 & 47 & 47 & 47 & 47 & 47 & 47 & 47 & 47 & 47 & 47 \\
\hline Adjusted $R^{2}$ & 0.151 & 0.413 & 0.447 & 0.124 & 0.413 & 0.441 & 0.234 & 0.280 & 0.349 & 0.208 & 0.273 & 0.310 \\
\hline
\end{tabular}

This table presents the results of a series of OLS regression standard errors are reported in parentheses. ${ }^{* * *}$ Significant at the 1 percent level. ${ }^{* *}$ Significant at the 5 percent level. ${ }^{*}$ Significant at the 10 percent level. 
Table B.28: Persistence of Institutions - Indigenous Autocracy

\begin{tabular}{|c|c|c|c|c|c|c|}
\hline & \multicolumn{2}{|c|}{$\begin{array}{l}\text { Executive } \\
\text { Constraints }\end{array}$} & \multicolumn{2}{|c|}{ Autocracy } & \multirow{2}{*}{$\begin{array}{c}\begin{array}{c}\text { Executive } \\
\text { Con- } \\
\text { straints }\end{array} \\
(5)\end{array}$} & \multirow{2}{*}{$\begin{array}{c}\text { Autocracy } \\
(6)\end{array}$} \\
\hline & $(1)$ & $(2)$ & (3) & (4) & & \\
\hline Log Indigenous Autocracy & $\begin{array}{c}-0.237^{* * *} \\
(0.070)\end{array}$ & & $\begin{array}{c}0.466^{* * *} \\
(0.158)\end{array}$ & & $\begin{array}{c}-0.287^{* * *} \\
(0.076)\end{array}$ & $\begin{array}{c}0.549^{* * *} \\
(0.169)\end{array}$ \\
\hline $\begin{array}{c}\text { Log Indigenous Autocracy } \\
\text { (Ancestry Adjusted) }\end{array}$ & & $\begin{array}{c}-0.377^{* * *} \\
(0.077)\end{array}$ & & $\begin{array}{c}0.764^{* * *} \\
(0.172)\end{array}$ & & \\
\hline$N$ & 95 & 95 & 95 & 95 & 80 & 80 \\
\hline Adjusted $R^{2}$ & 0.054 & 0.128 & 0.038 & 0.101 & 0.081 & 0.057 \\
\hline
\end{tabular}

This table presents the results of a series of OLS regression analyses, on the contemporary country level, of measures of contemporary autocracy on a measure of pre-colonial democracy. Specifications marked with "Continental FE" accounts for sub-Saharan Africa, Latin America, and continental fixed effects. Heteroscedasticity-consistent standard errors are reported in parentheses. ${ }^{* *}$ Significant at the 1 percent level. ${ }^{* *}$ Significant at the 5 percent level. * Significant at the 10 percent level. 
Table B.29: Persistence of Institutions - Alternative Aggregation Method

\begin{tabular}{|c|c|c|c|c|c|c|}
\hline & \multicolumn{2}{|c|}{$\begin{array}{l}\text { Executive } \\
\text { Constraints }\end{array}$} & \multicolumn{2}{|c|}{ Autocracy } & \multirow{2}{*}{$\begin{array}{c}\begin{array}{c}\text { Executive } \\
\text { Con- } \\
\text { straints }\end{array} \\
(5)\end{array}$} & \multirow{2}{*}{$\frac{\text { Autocracy }}{(6)}$} \\
\hline & (1) & $(2)$ & $(3)$ & $(4)$ & & \\
\hline Indigenous Democracy & $\begin{array}{r}0.248^{* * *} \\
(0.081)\end{array}$ & & $\begin{array}{c}-0.466^{* * *} \\
(0.168)\end{array}$ & & $\begin{array}{c}0.305^{* * *} \\
(0.085)\end{array}$ & $\begin{array}{c}-0.553^{* * *} \\
(0.176)\end{array}$ \\
\hline $\begin{array}{l}\text { Indigenous Democracy } \\
\text { (Ancestry Adjusted) }\end{array}$ & & $\begin{array}{c}0.313^{* * *} \\
(0.091)\end{array}$ & & $\begin{array}{c}-0.565^{* * *} \\
(0.191)\end{array}$ & & \\
\hline $\mathrm{N}$ & 144 & 144 & 144 & 144 & 127 & 127 \\
\hline Adjusted $R^{2}$ & 0.056 & 0.069 & 0.045 & 0.050 & 0.085 & 0.065 \\
\hline
\end{tabular}

This table presents the results of a series of OLS regression analyses, on the contemporary country level, of measures of contemporary autocracy on a measure of pre-colonial democracy, conditional on sub-Saharan Africa, Latin America, and continental fixed effects. Specifications marked with "Continental FE" accounts for subSaharan Africa, Latin America, and continental fixed effects. Heteroscedasticity-consistent standard errors are reported in parentheses. $* * *$ Significant at the 1 percent level. ** Significant at the 5 percent level. ${ }^{*}$ Significant at the 10 percent level.

This table shows the robustness of the findings in Table 11 and B.28 to using a measure of indigenous democracy (rather than indigenous autocracy) that is derived from an alternative aggregation procedure from the ethnic group level to the country level, based on Giuliano and Nunn (2013) (see Alesina et al. (2013) for an explanation of the methodology used in the construction of the data). This procedure generates a larger sample of countries with aggregated institutional information. 
Table B.30: Predicted Diversity and Constraint on the Executive (2013)

\begin{tabular}{|c|c|c|c|c|c|c|c|}
\hline & \multicolumn{7}{|c|}{ Log Constraint on Chief Executive } \\
\hline & $(1)$ & $(2)$ & (3) & $(4)$ & $(5)$ & $(6)$ & $(7)$ \\
\hline Predicted Genetic Diversity & $\begin{array}{c}-3.397^{* * *} \\
(0.902)\end{array}$ & $\begin{array}{c}-3.449^{* * *} \\
(0.898)\end{array}$ & $\begin{array}{c}-2.423^{* *} \\
(0.948)\end{array}$ & $\begin{array}{c}-2.495^{* * *} \\
(0.939)\end{array}$ & $\begin{array}{c}-3.081^{* *} \\
(1.547)\end{array}$ & $\begin{array}{c}-3.159^{* *} \\
(1.473)\end{array}$ & $\begin{array}{c}-3.277^{* *} \\
(1.464)\end{array}$ \\
\hline Log Absolute Latitude & & $\begin{array}{l}0.082^{* *} \\
(0.032)\end{array}$ & $\begin{array}{c}0.051 \\
(0.034)\end{array}$ & $\begin{array}{l}-0.044 \\
(0.049)\end{array}$ & $\begin{array}{c}0.018 \\
(0.051)\end{array}$ & $\begin{array}{c}0.016 \\
(0.048)\end{array}$ & $\begin{array}{c}0.023 \\
(0.048)\end{array}$ \\
\hline Soil Fertility & & & $\begin{array}{c}0.319 \\
(0.227)\end{array}$ & $\begin{array}{c}0.244 \\
(0.217)\end{array}$ & $\begin{array}{c}0.067 \\
(0.193)\end{array}$ & $\begin{array}{c}0.205 \\
(0.191)\end{array}$ & $\begin{array}{c}0.205 \\
(0.192)\end{array}$ \\
\hline Roughness & & & $\begin{array}{c}0.167 \\
(0.309)\end{array}$ & $\begin{array}{c}0.059 \\
(0.324)\end{array}$ & $\begin{array}{c}0.355 \\
(0.338)\end{array}$ & $\begin{array}{c}0.441 \\
(0.314)\end{array}$ & $\begin{array}{c}0.526^{*} \\
(0.304)\end{array}$ \\
\hline Elevation & & & $\begin{array}{c}0.039 \\
(0.084)\end{array}$ & $\begin{array}{l}0.013 \\
(0.084)\end{array}$ & $\begin{array}{c}0.109 \\
(0.105)\end{array}$ & $\begin{array}{c}0.048 \\
(0.096)\end{array}$ & $\begin{array}{c}0.047 \\
(0.090)\end{array}$ \\
\hline Average Distance to Nearest Waterway & & & $\begin{array}{c}-0.197^{* *} \\
(0.096)\end{array}$ & $\begin{array}{c}-0.265^{* * *} \\
(0.092)\end{array}$ & $\begin{array}{c}-0.171^{*} \\
(0.087)\end{array}$ & $\begin{array}{l}-0.080 \\
(0.092)\end{array}$ & $\begin{array}{l}-0.062 \\
(0.092)\end{array}$ \\
\hline Percentage of Arable Land & & & $\begin{array}{c}0.003 \\
(0.002)\end{array}$ & $\begin{array}{c}0.002 \\
(0.002)\end{array}$ & $\begin{array}{c}0.003 \\
(0.003)\end{array}$ & $\begin{array}{c}0.003 \\
(0.002)\end{array}$ & $\begin{array}{c}0.003 \\
(0.002)\end{array}$ \\
\hline Temperature & & & & $\begin{array}{c}-0.017^{* * *} \\
(0.006)\end{array}$ & $\begin{array}{l}-0.003 \\
(0.010)\end{array}$ & $\begin{array}{l}-0.005 \\
(0.010)\end{array}$ & $\begin{array}{l}-0.011 \\
(0.010)\end{array}$ \\
\hline Colony & & & & & & & $\begin{array}{c}0.258^{*} \\
(0.154)\end{array}$ \\
\hline Continental FE & No & No & No & No & Yes & Yes & Yes \\
\hline Legal Origin FE & No & No & No & No & No & Yes & Yes \\
\hline$N$ & 140 & 140 & 140 & 140 & 140 & 140 & 140 \\
\hline Adjusted $R^{2}$ & 0.050 & 0.082 & 0.175 & 0.228 & 0.330 & 0.390 & 0.406 \\
\hline
\end{tabular}

This table presents the results of a series of OLS regression analyses, on the contemporary country level, of a measure of contemporary autocracy on predicted genetic diversity, conditional on a range of control variables. Specifications marked with "Continental FE" accounts for sub-Saharan Africa, Latin America, and continental fixed effects. Heteroscedasticity-consistent standard errors are reported in parentheses. ${ }^{* *}$ Significant at the 1 percent level. ${ }^{* *}$ Significant at the 5 percent level. ${ }^{*}$ Significant at the 10 percent level. 
Table B.31: Predicted Diversity and Constraint on the Executive - Accounting for Irrigation Potential

\begin{tabular}{|c|c|c|c|c|c|c|c|}
\hline & \multicolumn{7}{|c|}{ Log Constraint on Chief Executive } \\
\hline & (1) & $(2)$ & $(3)$ & (4) & $(5)$ & (6) & (7) \\
\hline Predicted Genetic Diversity & $\begin{array}{c}-4.055^{* * *} \\
(0.811)\end{array}$ & $\begin{array}{c}-4.305^{* * *} \\
(0.828)\end{array}$ & $\begin{array}{c}-3.281^{* * *} \\
(0.893)\end{array}$ & $\begin{array}{c}-3.176^{* * *} \\
(0.828)\end{array}$ & $\begin{array}{c}-3.274^{* *} \\
(1.436)\end{array}$ & $\begin{array}{c}-3.332^{* *} \\
(1.344)\end{array}$ & $\begin{array}{c}-3.450^{* *} \\
(1.337)\end{array}$ \\
\hline Log Percentage of Area Equipped for Irrigation & $\begin{array}{l}-0.001 \\
(0.039)\end{array}$ & $\begin{array}{l}-0.042 \\
(0.039)\end{array}$ & $\begin{array}{c}-0.173^{* * *} \\
(0.047)\end{array}$ & $\begin{array}{c}-0.138^{* * *} \\
(0.051)\end{array}$ & $\begin{array}{c}-0.009 \\
(0.054)\end{array}$ & $\begin{array}{l}-0.037 \\
(0.056)\end{array}$ & $\begin{array}{l}-0.029 \\
(0.054)\end{array}$ \\
\hline Log Absolute Latitude & & $\begin{array}{c}0.108^{* * *} \\
(0.029)\end{array}$ & $\begin{array}{c}0.093^{* * *} \\
(0.030)\end{array}$ & $\begin{array}{l}-0.004 \\
(0.045)\end{array}$ & $\begin{array}{c}0.023 \\
(0.043)\end{array}$ & $\begin{array}{c}0.024 \\
(0.038)\end{array}$ & $\begin{array}{c}0.030 \\
(0.037)\end{array}$ \\
\hline Soil Fertility & & & $\begin{array}{l}0.477^{* *} \\
(0.221)\end{array}$ & $\begin{array}{l}0.416^{*} \\
(0.216)\end{array}$ & $\begin{array}{c}0.174 \\
(0.206)\end{array}$ & $\begin{array}{l}0.353^{*} \\
(0.202)\end{array}$ & $\begin{array}{l}0.339^{*} \\
(0.203)\end{array}$ \\
\hline Roughness & & & $\begin{array}{l}0.727^{* *} \\
(0.332)\end{array}$ & $\begin{array}{c}0.529 \\
(0.352)\end{array}$ & $\begin{array}{c}0.359 \\
(0.342)\end{array}$ & $\begin{array}{c}0.460 \\
(0.303)\end{array}$ & $\begin{array}{l}0.522^{*} \\
(0.297)\end{array}$ \\
\hline Elevation & & & $\begin{array}{l}-0.116 \\
(0.088)\end{array}$ & $\begin{array}{l}-0.135 \\
(0.090)\end{array}$ & $\begin{array}{c}-0.010 \\
(0.108)\end{array}$ & $\begin{array}{l}-0.072 \\
(0.100)\end{array}$ & $\begin{array}{l}-0.066 \\
(0.094)\end{array}$ \\
\hline Average Distance to Nearest Waterway & & & $\begin{array}{c}-0.155^{*} \\
(0.080)\end{array}$ & $\begin{array}{c}-0.219^{* * *} \\
(0.083)\end{array}$ & $\begin{array}{c}-0.160^{*} \\
(0.085)\end{array}$ & $\begin{array}{l}-0.067 \\
(0.091)\end{array}$ & $\begin{array}{l}-0.047 \\
(0.092)\end{array}$ \\
\hline Percentage of Arable Land & & & $\begin{array}{l}0.006^{* *} \\
(0.003)\end{array}$ & $\begin{array}{c}0.004 \\
(0.003)\end{array}$ & $\begin{array}{c}0.002 \\
(0.003)\end{array}$ & $\begin{array}{c}0.003 \\
(0.003)\end{array}$ & $\begin{array}{c}0.003 \\
(0.003)\end{array}$ \\
\hline Temperature & & & & $\begin{array}{c}-0.016^{* * *} \\
(0.006)\end{array}$ & $\begin{array}{l}-0.007 \\
(0.010)\end{array}$ & $\begin{array}{l}-0.009 \\
(0.010)\end{array}$ & $\begin{array}{l}-0.014 \\
(0.010)\end{array}$ \\
\hline Colony & & & & & & & $\begin{array}{l}0.259^{*} \\
(0.150)\end{array}$ \\
\hline Continental FE & No & No & No & No & Yes & Yes & Yes \\
\hline Legal Origin FE & No & No & No & No & No & Yes & Yes \\
\hline$N$ & 145 & 145 & 145 & 145 & 145 & 145 & 145 \\
\hline Adjusted $R^{2}$ & 0.061 & 0.109 & 0.296 & 0.334 & 0.400 & 0.454 & 0.469 \\
\hline
\end{tabular}

This table presents the results of a series of 2SLS regression analyses, on the contemporary country level, of a measure of contemporary autocracy on predicted genetic diversity, instrumented by the migratory distance from East Africa to the country, conditional on a range of control variables. Specifications marked with "Continental FE" accounts for sub-Saharan Africa, Latin America, and continental fixed effects. Heteroscedasticity-consistent standard errors are reported in parentheses. ${ }^{* *}$ Significant at the 1 percent level. ** Significant at the 5 percent level. * Significant at the 10 percent level.

This table establishes that the findings in Table 12 are robust to accounting for the irrigation potential. 
Table B.32: Predicted Diversity and Constraint on the Executive - Accounting for Percentage of Land near a Waterway

\begin{tabular}{|c|c|c|c|c|c|c|c|}
\hline & \multicolumn{7}{|c|}{ Log Constraint on Chief Executive } \\
\hline & (1) & (2) & $(3)$ & (4) & $(5)$ & (6) & (7) \\
\hline Predicted Genetic Diversity & $\begin{array}{c}-3.116^{* * *} \\
(0.855)\end{array}$ & $\begin{array}{c}-3.251^{* * *} \\
(0.876)\end{array}$ & $\begin{array}{c}-2.773^{* * *} \\
(0.889)\end{array}$ & $\begin{array}{c}-2.812^{* * *} \\
(0.873)\end{array}$ & $\begin{array}{c}-3.278^{* *} \\
(1.444)\end{array}$ & $\begin{array}{c}-3.364^{* *} \\
(1.352)\end{array}$ & $\begin{array}{c}-3.488^{* *} \\
(1.339)\end{array}$ \\
\hline Percentage of Land Near a Waterway & $\begin{array}{c}0.344^{* * *} \\
(0.089)\end{array}$ & $\begin{array}{c}0.306^{* * *} \\
(0.093)\end{array}$ & $\begin{array}{c}0.086 \\
(0.151)\end{array}$ & $\begin{array}{l}-0.018 \\
(0.144)\end{array}$ & $\begin{array}{c}0.016 \\
(0.136)\end{array}$ & $\begin{array}{l}-0.026 \\
(0.133)\end{array}$ & $\begin{array}{l}-0.047 \\
(0.134)\end{array}$ \\
\hline Log Absolute Latitude & & $\begin{array}{l}0.068^{* *} \\
(0.030)\end{array}$ & $\begin{array}{c}0.050 \\
(0.031)\end{array}$ & $\begin{array}{l}-0.059 \\
(0.042)\end{array}$ & $\begin{array}{c}0.022 \\
(0.043)\end{array}$ & $\begin{array}{c}0.018 \\
(0.038)\end{array}$ & $\begin{array}{c}0.025 \\
(0.038)\end{array}$ \\
\hline Soil Fertility & & & $\begin{array}{l}0.485^{*} \\
(0.246)\end{array}$ & $\begin{array}{l}0.418^{*} \\
(0.236)\end{array}$ & $\begin{array}{c}0.163 \\
(0.211)\end{array}$ & $\begin{array}{c}0.314 \\
(0.208)\end{array}$ & $\begin{array}{c}0.313 \\
(0.210)\end{array}$ \\
\hline Roughness & & & $\begin{array}{c}0.052 \\
(0.357)\end{array}$ & $\begin{array}{c}0.055 \\
(0.359)\end{array}$ & $\begin{array}{c}0.327 \\
(0.353)\end{array}$ & $\begin{array}{c}0.405 \\
(0.323)\end{array}$ & $\begin{array}{c}0.504 \\
(0.320)\end{array}$ \\
\hline Elevation & & & $\begin{array}{l}-0.028 \\
(0.120)\end{array}$ & $\begin{array}{l}-0.111 \\
(0.120)\end{array}$ & $\begin{array}{c}-0.001 \\
(0.130)\end{array}$ & $\begin{array}{l}-0.074 \\
(0.125)\end{array}$ & $\begin{array}{l}-0.080 \\
(0.120)\end{array}$ \\
\hline Average Distance to Nearest Waterway & & & $\begin{array}{c}-0.144 \\
(0.098)\end{array}$ & $\begin{array}{c}-0.254^{* * *} \\
(0.097)\end{array}$ & $\begin{array}{c}-0.155^{*} \\
(0.093)\end{array}$ & $\begin{array}{l}-0.078 \\
(0.100)\end{array}$ & $\begin{array}{l}-0.064 \\
(0.102)\end{array}$ \\
\hline Percentage of Arable Land & & & $\begin{array}{c}0.002 \\
(0.002)\end{array}$ & $\begin{array}{c}0.001 \\
(0.002)\end{array}$ & $\begin{array}{c}0.002 \\
(0.003)\end{array}$ & $\begin{array}{c}0.002 \\
(0.002)\end{array}$ & $\begin{array}{c}0.002 \\
(0.002)\end{array}$ \\
\hline Temperature & & & & $\begin{array}{c}-0.020^{* * *} \\
(0.006)\end{array}$ & $\begin{array}{c}-0.007 \\
(0.010)\end{array}$ & $\begin{array}{l}-0.010 \\
(0.010)\end{array}$ & $\begin{array}{l}-0.016 \\
(0.010)\end{array}$ \\
\hline Colony & & & & & & & $\begin{array}{l}0.268^{*} \\
(0.147)\end{array}$ \\
\hline Continental FE & No & No & No & $\mathrm{No}$ & Yes & Yes & Yes \\
\hline Legal Origin FE & No & No & No & No & No & Yes & Yes \\
\hline$N$ & 145 & 145 & 145 & 145 & 145 & 145 & 145 \\
\hline Adjusted $R^{2}$ & 0.156 & 0.174 & 0.218 & 0.287 & 0.400 & 0.452 & 0.468 \\
\hline
\end{tabular}

This table presents the results of a series of 2SLS regression analyses, on the contemporary country level, of a measure of contemporary autocracy on predicted genetic diversity, instrumented by the migratory distance from East Africa to the country, conditional on a range of control variables. Specifications marked with "Continental FE" accounts for sub-Saharan Africa, Latin America, and continental fixed effects. Heteroscedasticity-consistent standard errors are reported in parentheses. *** Significant at the 1 percent level. ${ }^{* *}$ Significant at the 5 percent level. ${ }^{*}$ Significant at the 10 percent level.

This table establishes that the findings in Table 12 are robust to accounting for the percentage of land near a waterway. 
Table B.33: Predicted Diversity and Constraint on the Executive - Accounting for the Inequality in Land Suitability

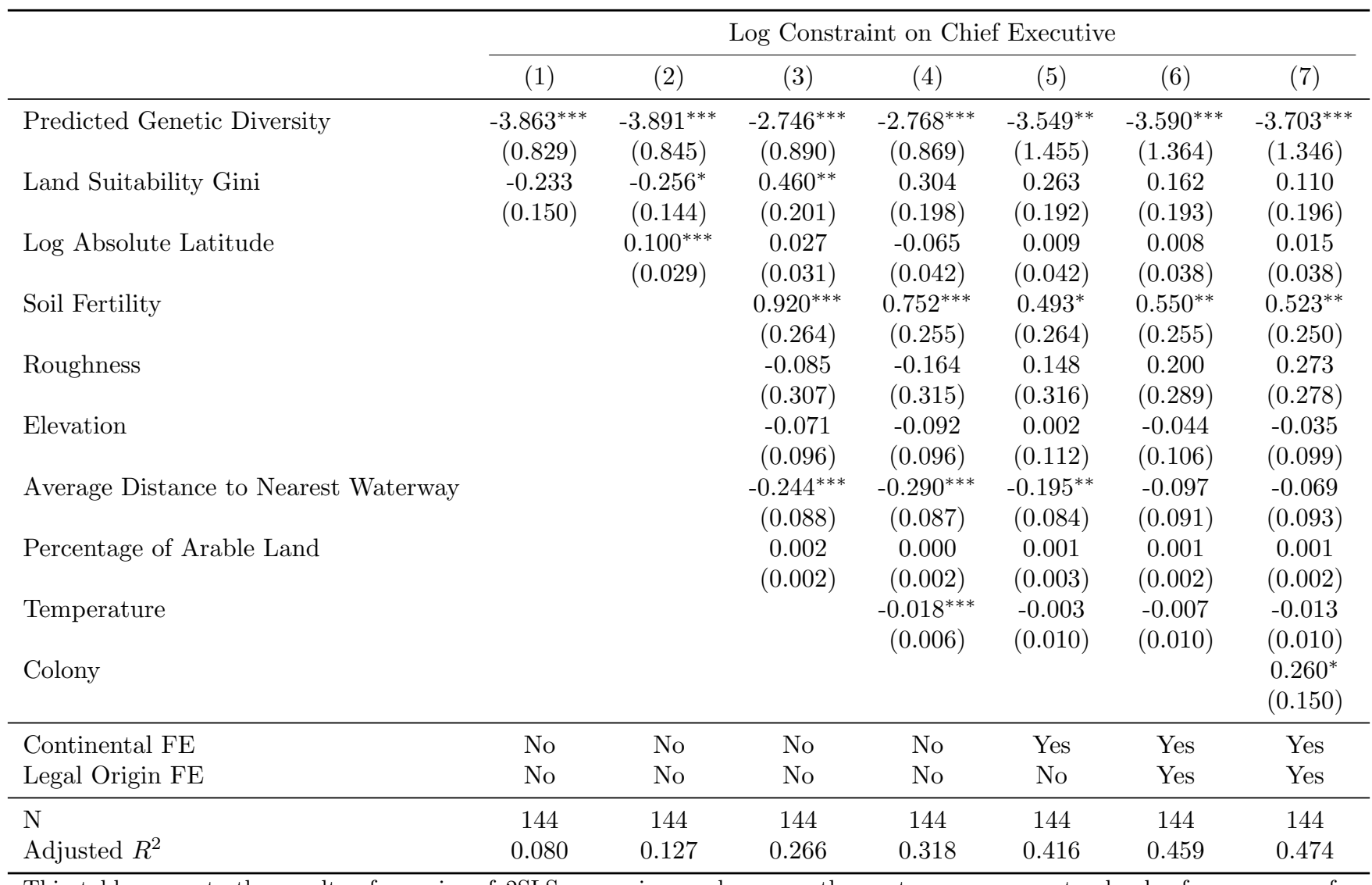

This table presents the results of a series of 2SLS regression analyses, on the contemporary country level, of a measure of contemporary autocracy on predicted genetic diversity, instrumented by the migratory distance from East Africa to the country, conditional on a range of control variables. Specifications marked with "Continental FE" accounts for sub-Saharan Africa, Latin America, and continental fixed effects. Heteroscedasticity-consistent standard errors are reported in parentheses. *** Significant at the 1 percent level. ${ }^{* *}$ Significant at the 5 percent level. ${ }^{*}$ Significant at the 10 percent level.

This table establishes that the findings in Table 12 are robust to accounting for the inequality of land suitability (i.e., the Gini coefficient of land suitability). 
Table B.34: Predicted Diversity and Constraint on the Executive - Accounting for Percentages of Population Living in Various Climate Zones

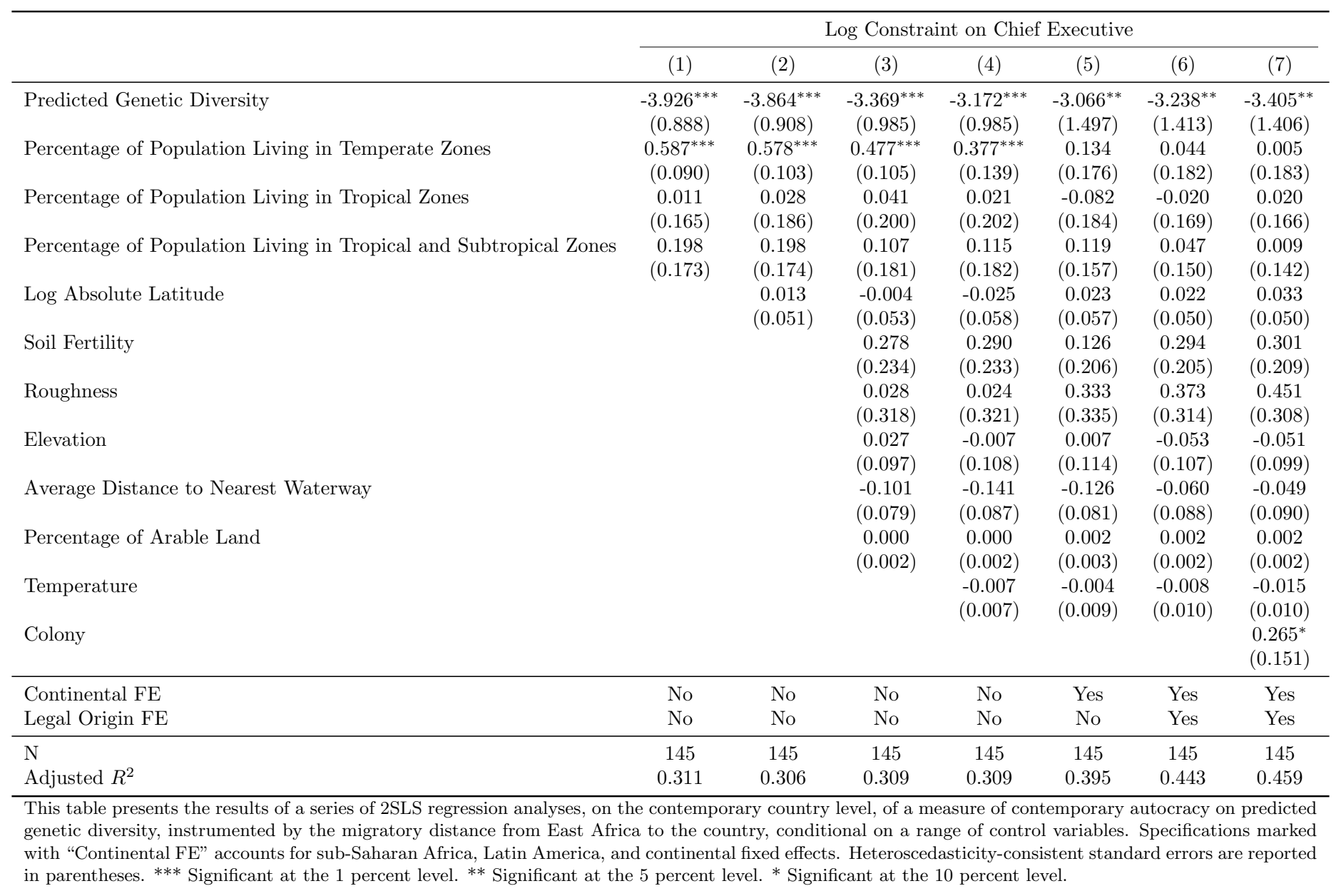

This table establishes that the findings in Table 12 are robust to accounting for the percentages of population living in various climate zones. 
Table B.35: Predicted Diversity and Constraint on the Executive - Accounting for Colonizer Nation

\begin{tabular}{|c|c|c|c|c|c|c|}
\hline & \multicolumn{6}{|c|}{ Log Constraint on Chief Executive } \\
\hline & (1) & $(2)$ & $(3)$ & (4) & $(5)$ & (6) \\
\hline Predicted Genetic Diversity & $\begin{array}{c}-3.442^{* * *} \\
(1.159)\end{array}$ & $\begin{array}{c}-3.293^{* * *} \\
(1.102)\end{array}$ & $\begin{array}{c}-2.869^{* *} \\
(1.131)\end{array}$ & $\begin{array}{c}-2.739^{* *} \\
(1.140)\end{array}$ & $\begin{array}{c}-4.115^{* *} \\
(1.606)\end{array}$ & $\begin{array}{c}-3.648^{* *} \\
(1.604)\end{array}$ \\
\hline British Colony & $\begin{array}{l}-0.072 \\
(0.102)\end{array}$ & $\begin{array}{l}-0.092 \\
(0.095)\end{array}$ & $\begin{array}{c}0.001 \\
(0.109)\end{array}$ & $\begin{array}{l}-0.006 \\
(0.103)\end{array}$ & $\begin{array}{c}0.163 \\
(0.109)\end{array}$ & $\begin{array}{c}0.051 \\
(0.152)\end{array}$ \\
\hline French Colony & $\begin{array}{c}-0.223^{* *} \\
(0.098)\end{array}$ & $\begin{array}{c}-0.223^{* *} \\
(0.092)\end{array}$ & $\begin{array}{l}-0.130 \\
(0.106)\end{array}$ & $\begin{array}{l}-0.077 \\
(0.113)\end{array}$ & $\begin{array}{c}0.078 \\
(0.096)\end{array}$ & $\begin{array}{c}0.109 \\
(0.103)\end{array}$ \\
\hline Other Colony & $\begin{array}{l}-0.052 \\
(0.114)\end{array}$ & $\begin{array}{l}-0.134 \\
(0.107)\end{array}$ & $\begin{array}{l}-0.107 \\
(0.118)\end{array}$ & $\begin{array}{c}-0.259^{* *} \\
(0.114)\end{array}$ & $\begin{array}{l}-0.105 \\
(0.111)\end{array}$ & $\begin{array}{l}-0.044 \\
(0.119)\end{array}$ \\
\hline Non-colony & $\begin{array}{c}0.122 \\
(0.104)\end{array}$ & $\begin{array}{c}0.032 \\
(0.101)\end{array}$ & $\begin{array}{c}0.068 \\
(0.099)\end{array}$ & $\begin{array}{l}-0.076 \\
(0.096)\end{array}$ & $\begin{array}{c}0.029 \\
(0.105)\end{array}$ & $\begin{array}{l}-0.095 \\
(0.123)\end{array}$ \\
\hline Log Absolute Latitude & & $\begin{array}{c}0.092^{* * *} \\
(0.028)\end{array}$ & $\begin{array}{l}0.057^{* *} \\
(0.028)\end{array}$ & $\begin{array}{l}-0.052 \\
(0.041)\end{array}$ & $\begin{array}{c}0.014 \\
(0.040)\end{array}$ & $\begin{array}{c}0.014 \\
(0.039)\end{array}$ \\
\hline Soil Fertility & & & $\begin{array}{l}0.450^{*} \\
(0.258)\end{array}$ & $\begin{array}{c}0.331 \\
(0.240)\end{array}$ & $\begin{array}{c}0.187 \\
(0.199)\end{array}$ & $\begin{array}{c}0.310 \\
(0.210)\end{array}$ \\
\hline Roughness & & & $\begin{array}{c}0.166 \\
(0.321)\end{array}$ & $\begin{array}{c}0.150 \\
(0.320)\end{array}$ & $\begin{array}{c}0.421 \\
(0.314)\end{array}$ & $\begin{array}{c}0.330 \\
(0.300)\end{array}$ \\
\hline Elevation & & & $\begin{array}{l}-0.046 \\
(0.090)\end{array}$ & $\begin{array}{l}-0.074 \\
(0.087)\end{array}$ & $\begin{array}{c}0.014 \\
(0.104)\end{array}$ & $\begin{array}{c}0.005 \\
(0.105)\end{array}$ \\
\hline Average Distance to Nearest Waterway & & & $\begin{array}{l}-0.123 \\
(0.091)\end{array}$ & $\begin{array}{c}-0.206^{* *} \\
(0.087)\end{array}$ & $\begin{array}{l}-0.118 \\
(0.087)\end{array}$ & $\begin{array}{l}-0.051 \\
(0.091)\end{array}$ \\
\hline Percentage of Arable Land & & & $\begin{array}{c}0.003 \\
(0.003)\end{array}$ & $\begin{array}{c}0.003 \\
(0.003)\end{array}$ & $\begin{array}{c}0.003 \\
(0.003)\end{array}$ & $\begin{array}{c}0.002 \\
(0.003)\end{array}$ \\
\hline Temperature & & & & $\begin{array}{c}-0.025^{* * *} \\
(0.006)\end{array}$ & $\begin{array}{l}-0.011 \\
(0.009) \\
\end{array}$ & $\begin{array}{l}-0.012 \\
(0.010) \\
\end{array}$ \\
\hline Continental FE & No & No & No & No & Yes & Yes \\
\hline Legal Origin FE & No & No & No & No & No & Yes \\
\hline $\begin{array}{l}\mathrm{N} \\
\text { Adjusted } R^{2}\end{array}$ & $\begin{array}{c}142 \\
0.108\end{array}$ & $\begin{array}{c}142 \\
0.140\end{array}$ & $\begin{array}{c}142 \\
0.235\end{array}$ & $\begin{array}{c}142 \\
0.329\end{array}$ & $\begin{array}{c}142 \\
0.439\end{array}$ & $\begin{array}{c}142 \\
0.470\end{array}$ \\
\hline $\begin{array}{l}\text { This table presents the results of a series of } \\
\text { of contemporary autocracy on predicted ge } \\
\text { to the country, conditional on a range of } \\
\text { for sub-Saharan Africa, Latin America, an } \\
\text { are reported in parentheses. *** Significan } \\
\text { at the } 10 \text { percent level. }\end{array}$ & $\begin{array}{l}5 \text { regress } \\
\text { c divers } \\
\text { ol varia } \\
\text { ntinent: }\end{array}$ & $\begin{array}{l}\text { analyses } \\
\text { instrume } \\
\text { xed effec } \\
\text { xed }\end{array}$ & $\begin{array}{l}\text { the con } \\
d \text { by the } \\
\text { ons mar } \\
\text { Heteros }\end{array}$ & $\begin{array}{l}\text { orary c } \\
\text { ratory " } \\
\text { with "C } \\
\text { sticity-c }\end{array}$ & $\begin{array}{l}\text { ry level } \\
\text { nce frol } \\
\text { nental } \\
\text { itent st }\end{array}$ & $\begin{array}{l}\text { measure } \\
\text { ast Africe } \\
\text { account } \\
\text { ard error } \\
\text { ignifican }\end{array}$ \\
\hline
\end{tabular}

This table establishes that the findings in Table 12 are robust to accounting for colonizer nation. 
Table B.36: Predicted Diversity and Constraint on the Executive - Accounting for Colonial Duration

\begin{tabular}{|c|c|c|c|c|c|c|c|}
\hline & \multicolumn{7}{|c|}{ Log Constraint on Chief Executive } \\
\hline & (1) & $(2)$ & $(3)$ & $(4)$ & $(5)$ & $(6)$ & $(7)$ \\
\hline Predicted Genetic Diversity & $\begin{array}{c}-3.565^{* * *} \\
(0.939)\end{array}$ & $\begin{array}{c}-3.137^{* * *} \\
(0.927)\end{array}$ & $\begin{array}{c}-2.079^{* *} \\
(1.035)\end{array}$ & $\begin{array}{c}-1.756^{*} \\
(0.985)\end{array}$ & $\begin{array}{l}-2.840^{*} \\
(1.456)\end{array}$ & $\begin{array}{c}-2.966^{* *} \\
(1.373)\end{array}$ & $\begin{array}{c}-3.134^{* *} \\
(1.370)\end{array}$ \\
\hline Colonial Duration & $\begin{array}{c}0.022 \\
(0.017)\end{array}$ & $\begin{array}{c}0.044^{* * *} \\
(0.014)\end{array}$ & $\begin{array}{c}0.035^{* *} \\
(0.017)\end{array}$ & $\begin{array}{c}0.049^{* * *} \\
(0.014)\end{array}$ & $\begin{array}{c}0.062^{* * *} \\
(0.015)\end{array}$ & $\begin{array}{c}0.050^{* * *} \\
(0.015)\end{array}$ & $\begin{array}{c}0.040^{* * *} \\
(0.013)\end{array}$ \\
\hline Log Absolute Latitude & & $\begin{array}{c}0.117^{* * *} \\
(0.028)\end{array}$ & $\begin{array}{l}0.075^{* *} \\
(0.031)\end{array}$ & $\begin{array}{l}-0.044 \\
(0.042)\end{array}$ & $\begin{array}{c}0.035 \\
(0.041)\end{array}$ & $\begin{array}{c}0.029 \\
(0.037)\end{array}$ & $\begin{array}{c}0.033 \\
(0.037)\end{array}$ \\
\hline Soil Fertility & & & $\begin{array}{l}0.464^{*} \\
(0.236)\end{array}$ & $\begin{array}{c}0.354 \\
(0.219)\end{array}$ & $\begin{array}{c}0.114 \\
(0.191)\end{array}$ & $\begin{array}{c}0.245 \\
(0.194)\end{array}$ & $\begin{array}{c}0.255 \\
(0.198)\end{array}$ \\
\hline Roughness & & & $\begin{array}{c}0.179 \\
(0.308)\end{array}$ & $\begin{array}{c}0.089 \\
(0.311)\end{array}$ & $\begin{array}{c}0.445 \\
(0.305)\end{array}$ & $\begin{array}{c}0.459 \\
(0.287)\end{array}$ & $\begin{array}{l}0.507^{*} \\
(0.284)\end{array}$ \\
\hline Elevation & & & $\begin{array}{l}-0.056 \\
(0.091)\end{array}$ & $\begin{array}{l}-0.095 \\
(0.091)\end{array}$ & $\begin{array}{l}-0.016 \\
(0.106)\end{array}$ & $\begin{array}{l}-0.061 \\
(0.101)\end{array}$ & $\begin{array}{l}-0.058 \\
(0.097)\end{array}$ \\
\hline Average Distance to Nearest Waterway & & & $\begin{array}{l}-0.167^{*} \\
(0.091)\end{array}$ & $\begin{array}{c}-0.253^{* * *} \\
(0.088)\end{array}$ & $\begin{array}{l}-0.147^{*} \\
(0.085)\end{array}$ & $\begin{array}{l}-0.066 \\
(0.091)\end{array}$ & $\begin{array}{l}-0.051 \\
(0.092)\end{array}$ \\
\hline Percentage of Arable Land & & & $\begin{array}{c}0.002 \\
(0.002)\end{array}$ & $\begin{array}{c}0.001 \\
(0.002)\end{array}$ & $\begin{array}{c}0.001 \\
(0.002)\end{array}$ & $\begin{array}{c}0.001 \\
(0.002)\end{array}$ & $\begin{array}{c}0.002 \\
(0.002)\end{array}$ \\
\hline Temperature & & & & $\begin{array}{c}-0.022^{* * *} \\
(0.005)\end{array}$ & $\begin{array}{l}-0.010 \\
(0.009)\end{array}$ & $\begin{array}{l}-0.012 \\
(0.010)\end{array}$ & $\begin{array}{l}-0.016 \\
(0.010)\end{array}$ \\
\hline Colony & & & & & & & $\begin{array}{c}0.205 \\
(0.151)\end{array}$ \\
\hline Continental FE & No & No & No & No & Yes & Yes & Yes \\
\hline Legal Origin FE & No & No & No & No & No & Yes & Yes \\
\hline $\begin{array}{l}\mathrm{N} \\
\text { Adjusted } R^{2}\end{array}$ & $\begin{array}{c}145 \\
0.068\end{array}$ & $\begin{array}{c}145 \\
0.128\end{array}$ & $\begin{array}{c}145 \\
0.232\end{array}$ & $\begin{array}{c}145 \\
0.320\end{array}$ & $\begin{array}{c}145 \\
0.434\end{array}$ & $\begin{array}{c}145 \\
0.473\end{array}$ & $\begin{array}{c}145 \\
0.480\end{array}$ \\
\hline
\end{tabular}

This table presents the results of a series of 2SLS regression analyses, on the contemporary country level, of a measure of contemporary autocracy on predicted genetic diversity, instrumented by the migratory distance from East Africa to the country, conditional on a range of control variables. Specifications marked with "Continental FE" accounts for sub-Saharan Africa, Latin America, and continental fixed effects. Heteroscedasticity-consistent standard errors are reported in parentheses. ${ }^{* * *}$ Significant at the 1 percent level. ${ }^{* *}$ Significant at the 5 percent level. ${ }^{*}$ Significant at the 10 percent level.

This table establishes that the findings in Table 12 are robust to accounting for colonial duration. 
Table B.37: Predicted Diversity and Constraint on the Executive - Accounting for GDP

\begin{tabular}{|c|c|c|c|c|c|c|c|}
\hline & & & Log Constr & aint on Chi & f Executive & & \\
\hline & $(1)$ & $(2)$ & $(3)$ & $(4)$ & $(5)$ & $(6)$ & $(7)$ \\
\hline Predicted Genetic Diversity & $\begin{array}{c}-3.348^{* * *} \\
(0.857)\end{array}$ & $\begin{array}{c}-3.460^{* * *} \\
(0.914)\end{array}$ & $\begin{array}{c}-2.467^{* * *} \\
(0.905)\end{array}$ & $\begin{array}{c}-2.629^{* * *} \\
(0.964)\end{array}$ & $\begin{array}{c}-3.677^{* * *} \\
(1.361)\end{array}$ & $\begin{array}{c}-3.440^{* * *} \\
(1.294)\end{array}$ & $\begin{array}{c}-3.608^{* * *} \\
(1.313)\end{array}$ \\
\hline Log Income Per Capita in $2000 \mathrm{CE}$ & $\begin{array}{c}0.112^{* * *} \\
(0.028)\end{array}$ & $\begin{array}{c}0.099^{* * *} \\
(0.036)\end{array}$ & $\begin{array}{c}0.103^{* * *} \\
(0.036)\end{array}$ & $\begin{array}{c}0.060 \\
(0.054)\end{array}$ & $\begin{array}{c}0.060 \\
(0.048)\end{array}$ & $\begin{array}{c}0.013 \\
(0.053)\end{array}$ & $\begin{array}{c}0.015 \\
(0.050)\end{array}$ \\
\hline Log Absolute Latitude & & $\begin{array}{c}0.034 \\
(0.037)\end{array}$ & $\begin{array}{l}-0.012 \\
(0.037)\end{array}$ & $\begin{array}{l}-0.066 \\
(0.044)\end{array}$ & $\begin{array}{c}0.022 \\
(0.044)\end{array}$ & $\begin{array}{c}0.018 \\
(0.038)\end{array}$ & $\begin{array}{c}0.027 \\
(0.038)\end{array}$ \\
\hline Soil Fertility & & & $\begin{array}{c}0.560^{* *} \\
(0.231)\end{array}$ & $\begin{array}{c}0.471^{* *} \\
(0.223)\end{array}$ & $\begin{array}{c}0.196 \\
(0.208)\end{array}$ & $\begin{array}{c}0.312 \\
(0.204)\end{array}$ & $\begin{array}{c}0.306 \\
(0.205)\end{array}$ \\
\hline Roughness & & & $\begin{array}{c}-0.067 \\
(0.309)\end{array}$ & $\begin{array}{l}-0.049 \\
(0.324)\end{array}$ & $\begin{array}{c}0.355 \\
(0.323)\end{array}$ & $\begin{array}{c}0.388 \\
(0.299)\end{array}$ & $\begin{array}{c}0.477 \\
(0.292)\end{array}$ \\
\hline Elevation & & & $\begin{array}{c}0.032 \\
(0.094)\end{array}$ & $\begin{array}{l}-0.036 \\
(0.109)\end{array}$ & $\begin{array}{c}0.024 \\
(0.109)\end{array}$ & $\begin{array}{l}-0.054 \\
(0.104)\end{array}$ & $\begin{array}{c}-0.046 \\
(0.099)\end{array}$ \\
\hline Average Distance to Nearest Waterway & & & $\begin{array}{c}-0.139 \\
(0.092)\end{array}$ & $\begin{array}{c}-0.209^{* *} \\
(0.099)\end{array}$ & $\begin{array}{c}-0.129 \\
(0.088)\end{array}$ & $\begin{array}{l}-0.067 \\
(0.093)\end{array}$ & $\begin{array}{l}-0.046 \\
(0.093)\end{array}$ \\
\hline Percentage of Arable Land & & & $\begin{array}{c}0.003 \\
(0.002)\end{array}$ & $\begin{array}{c}0.001 \\
(0.002)\end{array}$ & $\begin{array}{c}0.003 \\
(0.003)\end{array}$ & $\begin{array}{c}0.002 \\
(0.002)\end{array}$ & $\begin{array}{c}0.002 \\
(0.002)\end{array}$ \\
\hline Temperature & & & & $\begin{array}{c}-0.014^{*} \\
(0.008)\end{array}$ & $\begin{array}{c}-0.004 \\
(0.010)\end{array}$ & $\begin{array}{l}-0.009 \\
(0.011)\end{array}$ & $\begin{array}{l}-0.014 \\
(0.011)\end{array}$ \\
\hline Colony & & & & & & & $\begin{array}{l}0.276^{*} \\
(0.151)\end{array}$ \\
\hline Continental FE & No & No & No & No & Yes & Yes & Yes \\
\hline Legal Origin FE & No & No & No & No & No & Yes & Yes \\
\hline$N$ & 144 & 144 & 144 & 144 & 144 & 144 & 144 \\
\hline Adjusted $R^{2}$ & 0.171 & 0.170 & 0.278 & 0.303 & 0.411 & 0.448 & 0.465 \\
\hline
\end{tabular}

This table presents the results of a series of 2SLS regression analyses, on the contemporary country level, of a measure of contemporary autocracy on predicted genetic diversity, instrumented by the migratory distance from East Africa to the country, conditional on a range of control variables. Specifications marked with "Continental FE" accounts for sub-Saharan Africa, Latin America, and continental fixed effects. Heteroscedasticity-consistent standard errors are reported in parentheses. *** Significant at the 1 percent level. ${ }^{* *}$ Significant at the 5 percent level. * Significant at the 10 percent level.

This table establishes that the findings in Table 12 are robust to accounting for mid-period income per capita (i.e., income per capita in year 2000). 
Table B.38: Predicted Diversity and Constraint on the Executive - Accounting for Schooling

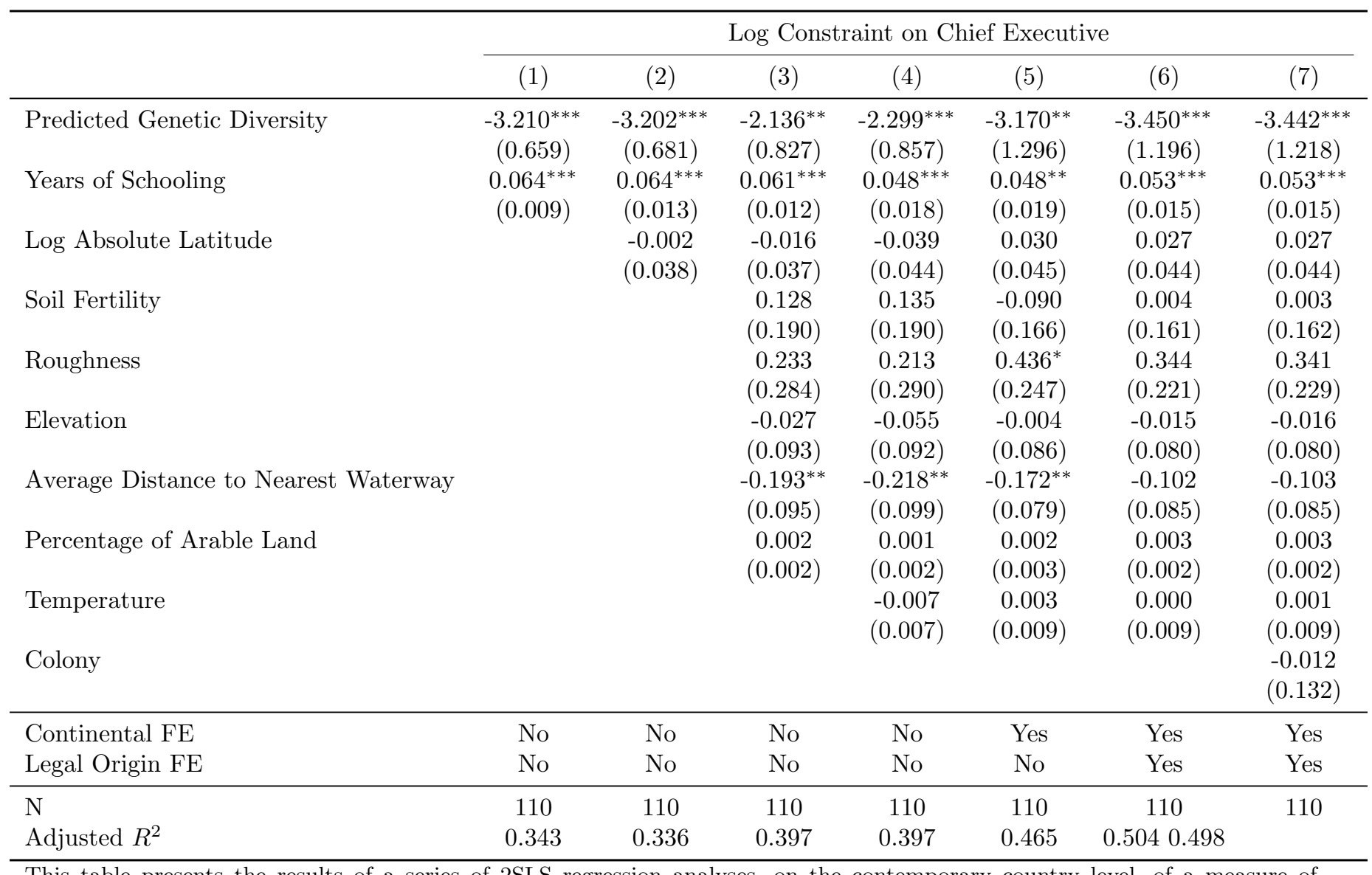

This table presents the results of a series of 2SLS regression analyses, on the contemporary country level, of a measure of contemporary autocracy on predicted genetic diversity, instrumented by the migratory distance from East Africa to the country, conditional on a range of control variables. Specifications marked with "Continental FE" accounts for sub-Saharan Africa, Latin America, and continental fixed effects. Heteroscedasticity-consistent standard errors are reported in parentheses. ${ }^{* * *}$ Significant at the 1 percent level. ${ }^{* *}$ Significant at the 5 percent level. * Significant at the 10 percent level.

This table establishes that the findings in Table 12 are robust to accounting for years of schooling. 
Table B.39: Predicted Diversity and Constraint on the Executive - Accounting for Population Density in 1500

\begin{tabular}{|c|c|c|c|c|c|c|c|}
\hline & \multicolumn{7}{|c|}{ Log Constraint on Chief Executive } \\
\hline & $(1)$ & $(2)$ & $(3)$ & (4) & $(5)$ & (6) & (7) \\
\hline Predicted Genetic Diversity & $\begin{array}{c}-4.135^{* * *} \\
(0.846)\end{array}$ & $\begin{array}{c}-4.173^{* * *} \\
(0.852)\end{array}$ & $\begin{array}{c}-2.866^{* * *} \\
(0.879)\end{array}$ & $\begin{array}{c}-2.873^{* * *} \\
(0.863)\end{array}$ & $\begin{array}{c}-3.015^{* *} \\
(1.432)\end{array}$ & $\begin{array}{c}-3.446^{* *} \\
(1.349)\end{array}$ & $\begin{array}{c}-3.530^{* *} \\
(1.349)\end{array}$ \\
\hline Population Density in $1500 \mathrm{CE}$ & $\begin{array}{c}0.012^{* * *} \\
(0.003)\end{array}$ & $\begin{array}{c}0.010^{* * *} \\
(0.003)\end{array}$ & $\begin{array}{l}0.005^{*} \\
(0.003)\end{array}$ & $\begin{array}{c}0.003 \\
(0.003)\end{array}$ & $\begin{array}{c}0.007^{* *} \\
(0.003)\end{array}$ & $\begin{array}{c}0.002 \\
(0.005)\end{array}$ & $\begin{array}{c}0.002 \\
(0.005)\end{array}$ \\
\hline Log Absolute Latitude & & $\begin{array}{c}0.077^{* * *} \\
(0.029)\end{array}$ & $\begin{array}{l}0.055^{*} \\
(0.030)\end{array}$ & $\begin{array}{l}-0.055 \\
(0.042)\end{array}$ & $\begin{array}{c}0.032 \\
(0.043)\end{array}$ & $\begin{array}{c}0.024 \\
(0.037)\end{array}$ & $\begin{array}{c}0.029 \\
(0.037)\end{array}$ \\
\hline Soil Fertility & & & $\begin{array}{l}0.465^{*} \\
(0.248)\end{array}$ & $\begin{array}{c}0.373 \\
(0.233)\end{array}$ & $\begin{array}{c}0.113 \\
(0.202)\end{array}$ & $\begin{array}{c}0.254 \\
(0.194)\end{array}$ & $\begin{array}{c}0.257 \\
(0.197)\end{array}$ \\
\hline Roughness & & & $\begin{array}{c}0.103 \\
(0.318)\end{array}$ & $\begin{array}{c}0.023 \\
(0.327)\end{array}$ & $\begin{array}{c}0.305 \\
(0.316)\end{array}$ & $\begin{array}{c}0.389 \\
(0.292)\end{array}$ & $\begin{array}{c}0.459 \\
(0.287)\end{array}$ \\
\hline Elevation & & & $\begin{array}{l}-0.029 \\
(0.096)\end{array}$ & $\begin{array}{l}-0.062 \\
(0.094)\end{array}$ & $\begin{array}{c}0.031 \\
(0.105)\end{array}$ & $\begin{array}{l}-0.017 \\
(0.099)\end{array}$ & $\begin{array}{l}-0.020 \\
(0.093)\end{array}$ \\
\hline Average Distance to Nearest Waterway & & & $\begin{array}{l}-0.182^{*} \\
(0.094)\end{array}$ & $\begin{array}{c}-0.265^{* * *} \\
(0.088)\end{array}$ & $\begin{array}{c}-0.170^{* *} \\
(0.082)\end{array}$ & $\begin{array}{l}-0.097 \\
(0.087)\end{array}$ & $\begin{array}{c}-0.075 \\
(0.089)\end{array}$ \\
\hline Percentage of Arable Land & & & $\begin{array}{c}0.000 \\
(0.003)\end{array}$ & $\begin{array}{l}-0.000 \\
(0.003)\end{array}$ & $\begin{array}{c}0.000 \\
(0.003)\end{array}$ & $\begin{array}{c}0.001 \\
(0.003)\end{array}$ & $\begin{array}{c}0.002 \\
(0.003)\end{array}$ \\
\hline Temperature & & & & $\begin{array}{c}-0.020^{* * *} \\
(0.005)\end{array}$ & $\begin{array}{c}-0.006 \\
(0.010)\end{array}$ & $\begin{array}{l}-0.010 \\
(0.010)\end{array}$ & $\begin{array}{c}-0.014 \\
(0.010)\end{array}$ \\
\hline Colony & & & & & & & $\begin{array}{c}0.230 \\
(0.151)\end{array}$ \\
\hline Continental FE & No & No & No & No & Yes & Yes & Yes \\
\hline Legal Origin FE & No & No & No & No & No & Yes & Yes \\
\hline $\mathrm{N}$ & 144 & 144 & 144 & 144 & 144 & 144 & 144 \\
\hline Adjusted $R^{2}$ & 0.130 & 0.155 & 0.227 & 0.295 & 0.419 & 0.465 & 0.476 \\
\hline
\end{tabular}

This table presents the results of a series of 2SLS regression analyses, on the contemporary country level, of a measure of contemporary autocracy on predicted genetic diversity, instrumented by the migratory distance from East Africa to the country, conditional on a range of control variables. Specifications marked with "Continental FE" accounts for sub-Saharan Africa, Latin America, and continental fixed effects. Heteroscedasticity-consistent standard errors are reported in parentheses. *** Significant at the 1 percent level. ${ }^{* *}$ Significant at the 5 percent level. $*$ Significant at the 10 percent level.

This table establishes that the findings in Table 12 are robust to accounting for population density in 1500 . 
Table B.40: Predicted Diversity and Constraint on the Executive - Accounting for Social Infrastructure

\begin{tabular}{|c|c|c|c|c|c|c|c|}
\hline & \multicolumn{7}{|c|}{ Log Constraint on Chief Executive } \\
\hline & (1) & $(2)$ & (3) & $(4)$ & $(5)$ & (6) & $(7)$ \\
\hline Predicted Genetic Diversity & $\begin{array}{c}-3.395^{* * *} \\
(0.728)\end{array}$ & $\begin{array}{c}-3.582^{* * *} \\
(0.724)\end{array}$ & $\begin{array}{c}-2.553^{* * *} \\
(0.848)\end{array}$ & $\begin{array}{c}-2.974^{* * *} \\
(0.891)\end{array}$ & $\begin{array}{c}-2.345^{* *} \\
(1.173)\end{array}$ & $\begin{array}{c}-3.030^{* * *} \\
(1.151)\end{array}$ & $\begin{array}{c}-3.048^{* *} \\
(1.159)\end{array}$ \\
\hline Social Infrastructure & $\begin{array}{c}0.593^{* * *} \\
(0.088)\end{array}$ & $\begin{array}{c}0.463^{* * *} \\
(0.114)\end{array}$ & $\begin{array}{c}0.445^{* * *} \\
(0.104)\end{array}$ & $\begin{array}{c}0.139 \\
(0.173)\end{array}$ & $\begin{array}{c}0.222 \\
(0.192)\end{array}$ & $\begin{array}{c}0.070 \\
(0.240)\end{array}$ & $\begin{array}{c}0.087 \\
(0.251)\end{array}$ \\
\hline Log Absolute Latitude & & $\begin{array}{l}0.068^{* *} \\
(0.031)\end{array}$ & $\begin{array}{c}0.043 \\
(0.031)\end{array}$ & $\begin{array}{l}-0.013 \\
(0.041)\end{array}$ & $\begin{array}{c}0.030 \\
(0.041)\end{array}$ & $\begin{array}{c}0.029 \\
(0.039)\end{array}$ & $\begin{array}{c}0.030 \\
(0.039)\end{array}$ \\
\hline Soil Fertility & & & $\begin{array}{c}0.387 \\
(0.244)\end{array}$ & $\begin{array}{c}0.326 \\
(0.219)\end{array}$ & $\begin{array}{c}0.091 \\
(0.180)\end{array}$ & $\begin{array}{c}0.084 \\
(0.172)\end{array}$ & $\begin{array}{c}0.084 \\
(0.173)\end{array}$ \\
\hline Roughness & & & $\begin{array}{c}0.404 \\
(0.298)\end{array}$ & $\begin{array}{c}0.400 \\
(0.300)\end{array}$ & $\begin{array}{l}0.477^{*} \\
(0.279)\end{array}$ & $\begin{array}{l}0.538^{*} \\
(0.275)\end{array}$ & $\begin{array}{c}0.554^{*} \\
(0.289)\end{array}$ \\
\hline Elevation & & & $\begin{array}{l}-0.119 \\
(0.098)\end{array}$ & $\begin{array}{l}-0.189 \\
(0.115)\end{array}$ & $\begin{array}{l}-0.158 \\
(0.106)\end{array}$ & $\begin{array}{c}-0.188^{*} \\
(0.106)\end{array}$ & $\begin{array}{c}-0.195^{*} \\
(0.112)\end{array}$ \\
\hline Average Distance to Nearest Waterway & & & $\begin{array}{c}0.018 \\
(0.125)\end{array}$ & $\begin{array}{c}-0.022 \\
(0.126)\end{array}$ & $\begin{array}{l}-0.034 \\
(0.143)\end{array}$ & $\begin{array}{c}0.005 \\
(0.145)\end{array}$ & $\begin{array}{c}0.013 \\
(0.150)\end{array}$ \\
\hline Percentage of Arable Land & & & $\begin{array}{c}0.001 \\
(0.002)\end{array}$ & $\begin{array}{c}0.001 \\
(0.002)\end{array}$ & $\begin{array}{c}0.004 \\
(0.003)\end{array}$ & $\begin{array}{c}0.003 \\
(0.003)\end{array}$ & $\begin{array}{c}0.003 \\
(0.003)\end{array}$ \\
\hline Temperature & & & & $\begin{array}{c}-0.017^{* *} \\
(0.007)\end{array}$ & $\begin{array}{c}-0.015^{* *} \\
(0.007)\end{array}$ & $\begin{array}{c}-0.018^{* *} \\
(0.008)\end{array}$ & $\begin{array}{c}-0.019^{* *} \\
(0.009)\end{array}$ \\
\hline Colony & & & & & & & $\begin{array}{c}0.072 \\
(0.202) \\
\end{array}$ \\
\hline Continental FE & No & No & No & No & Yes & Yes & Yes \\
\hline Legal Origin FE & No & No & No & No & No & Yes & Yes \\
\hline $\mathrm{N}$ & 108 & 108 & 108 & 108 & 108 & 108 & 108 \\
\hline Adjusted $R^{2}$ & 0.286 & 0.306 & 0.353 & 0.394 & 0.448 & 0.461 & 0.457 \\
\hline
\end{tabular}

This table establishes that the findings in Table 12 are robust to accounting for social infrastructure. 
Table B.41: Predicted Diversity and Constraint on the Executive - Accounting for Ethnic Fractionalization

\begin{tabular}{|c|c|c|c|c|c|c|c|}
\hline & \multicolumn{7}{|c|}{ Log Constraint on Chief Executive } \\
\hline & $(1)$ & $(2)$ & $(3)$ & (4) & $(5)$ & (6) & (7) \\
\hline Predicted Genetic Diversity & $\begin{array}{c}-3.271^{* * *} \\
(0.838)\end{array}$ & $\begin{array}{c}-3.509^{* * *} \\
(0.855)\end{array}$ & $\begin{array}{c}-2.766^{* * *} \\
(0.903)\end{array}$ & $\begin{array}{c}-2.923^{* * *} \\
(0.865)\end{array}$ & $\begin{array}{c}-3.233^{* *} \\
(1.450)\end{array}$ & $\begin{array}{c}-3.373^{* *} \\
(1.379)\end{array}$ & $\begin{array}{c}-3.470^{* *} \\
(1.369)\end{array}$ \\
\hline Ethnic Fractionalization & $\begin{array}{c}-0.373^{* * *} \\
(0.126)\end{array}$ & $\begin{array}{c}-0.265^{*} \\
(0.157)\end{array}$ & $\begin{array}{l}-0.017 \\
(0.175)\end{array}$ & $\begin{array}{c}0.115 \\
(0.161)\end{array}$ & $\begin{array}{c}-0.010 \\
(0.158)\end{array}$ & $\begin{array}{c}0.076 \\
(0.175)\end{array}$ & $\begin{array}{c}0.087 \\
(0.167)\end{array}$ \\
\hline Log Absolute Latitude & & $\begin{array}{c}0.056 \\
(0.036)\end{array}$ & $\begin{array}{c}0.053 \\
(0.034)\end{array}$ & $\begin{array}{l}-0.049 \\
(0.045)\end{array}$ & $\begin{array}{c}0.022 \\
(0.043)\end{array}$ & $\begin{array}{c}0.021 \\
(0.038)\end{array}$ & $\begin{array}{c}0.029 \\
(0.037)\end{array}$ \\
\hline Soil Fertility & & & $\begin{array}{l}0.475^{*} \\
(0.246)\end{array}$ & $\begin{array}{l}0.410^{*} \\
(0.231)\end{array}$ & $\begin{array}{c}0.160 \\
(0.208)\end{array}$ & $\begin{array}{c}0.328 \\
(0.202)\end{array}$ & $\begin{array}{c}0.323 \\
(0.201)\end{array}$ \\
\hline Roughness & & & $\begin{array}{c}0.138 \\
(0.342)\end{array}$ & $\begin{array}{c}0.101 \\
(0.349)\end{array}$ & $\begin{array}{c}0.334 \\
(0.331)\end{array}$ & $\begin{array}{c}0.403 \\
(0.304)\end{array}$ & $\begin{array}{c}0.486 \\
(0.294)\end{array}$ \\
\hline Elevation & & & $\begin{array}{l}-0.061 \\
(0.100)\end{array}$ & $\begin{array}{l}-0.117 \\
(0.100)\end{array}$ & $\begin{array}{l}-0.004 \\
(0.112)\end{array}$ & $\begin{array}{l}-0.071 \\
(0.105)\end{array}$ & $\begin{array}{l}-0.066 \\
(0.098)\end{array}$ \\
\hline Average Distance to Nearest Waterway & & & $\begin{array}{l}-0.174^{*} \\
(0.095)\end{array}$ & $\begin{array}{c}-0.259^{* * *} \\
(0.091)\end{array}$ & $\begin{array}{c}-0.161^{*} \\
(0.085)\end{array}$ & $\begin{array}{l}-0.074 \\
(0.090)\end{array}$ & $\begin{array}{c}-0.054 \\
(0.091)\end{array}$ \\
\hline Percentage of Arable Land & & & $\begin{array}{c}0.002 \\
(0.003)\end{array}$ & $\begin{array}{c}0.001 \\
(0.003)\end{array}$ & $\begin{array}{c}0.002 \\
(0.003)\end{array}$ & $\begin{array}{c}0.002 \\
(0.003)\end{array}$ & $\begin{array}{c}0.002 \\
(0.003)\end{array}$ \\
\hline Temperature & & & & $\begin{array}{c}-0.021^{* * *} \\
(0.005)\end{array}$ & $\begin{array}{c}-0.006 \\
(0.010)\end{array}$ & $\begin{array}{l}-0.010 \\
(0.010)\end{array}$ & $\begin{array}{c}-0.016^{*} \\
(0.009)\end{array}$ \\
\hline Colony & & & & & & & $\begin{array}{c}0.270^{*} \\
(0.145)\end{array}$ \\
\hline Continental FE & No & No & No & No & Yes & Yes & Yes \\
\hline Legal Origin FE & No & No & No & No & No & Yes & Yes \\
\hline $\mathrm{N}$ & 144 & 144 & 144 & 144 & 144 & 144 & 144 \\
\hline Adjusted $R^{2}$ & 0.114 & 0.120 & 0.210 & 0.284 & 0.394 & 0.447 & 0.463 \\
\hline
\end{tabular}

This table presents the results of a series of 2SLS regression analyses, on the contemporary country level, of a measure of contemporary autocracy on predicted genetic diversity, instrumented by the migratory distance from East Africa to the country, conditional on a range of control variables. Specifications marked with "Continental FE" accounts for sub-Saharan Africa, Latin America, and continental fixed effects. Heteroscedasticity-consistent standard errors are reported in parentheses. $* * *$ Significant at the 1 percent level. ${ }^{* *}$ Significant at the 5 percent level. ${ }^{*}$ Significant at the 10 percent level.

This table establishes that the findings in Table 12 are robust to accounting for ethnic fractionalization. 
Table B.42: Predicted Genetic Diversity and Autocracy (2013)

\begin{tabular}{|c|c|c|c|c|c|c|c|}
\hline & \multicolumn{7}{|c|}{ Log Autocracy } \\
\hline & (1) & $(2)$ & $(3)$ & (4) & $(5)$ & (6) & $(7)$ \\
\hline Predicted Genetic Diversity & $\begin{array}{c}7.878^{* * *} \\
(1.933)\end{array}$ & $\begin{array}{c}7.938^{* * *} \\
(1.942)\end{array}$ & $\begin{array}{c}5.845^{* * *} \\
(2.210)\end{array}$ & $\begin{array}{c}5.983^{* * *} \\
(2.218)\end{array}$ & $\begin{array}{l}6.795^{*} \\
(3.566)\end{array}$ & $\begin{array}{l}6.992^{* *} \\
(3.173)\end{array}$ & $\begin{array}{l}6.963^{* *} \\
(3.239)\end{array}$ \\
\hline Log Absolute Latitude & & $\begin{array}{l}-0.094 \\
(0.060)\end{array}$ & $\begin{array}{l}-0.023 \\
(0.065)\end{array}$ & $\begin{array}{c}0.158^{*} \\
(0.094)\end{array}$ & $\begin{array}{c}0.013 \\
(0.101)\end{array}$ & $\begin{array}{c}0.023 \\
(0.093)\end{array}$ & $\begin{array}{c}0.031 \\
(0.096)\end{array}$ \\
\hline Soil Fertility & & & $\begin{array}{l}-0.823^{*} \\
(0.494)\end{array}$ & $\begin{array}{l}-0.681 \\
(0.479)\end{array}$ & $\begin{array}{l}-0.254 \\
(0.407)\end{array}$ & $\begin{array}{l}-0.619 \\
(0.398)\end{array}$ & $\begin{array}{l}-0.507 \\
(0.524)\end{array}$ \\
\hline Roughness & & & $\begin{array}{l}-0.433 \\
(0.672)\end{array}$ & $\begin{array}{l}-0.226 \\
(0.710)\end{array}$ & $\begin{array}{l}-0.834 \\
(0.716)\end{array}$ & $\begin{array}{l}-0.931 \\
(0.636)\end{array}$ & $\begin{array}{l}-0.496 \\
(0.663)\end{array}$ \\
\hline Elevation & & & $\begin{array}{c}0.098 \\
(0.192)\end{array}$ & $\begin{array}{c}0.147 \\
(0.197)\end{array}$ & $\begin{array}{l}-0.064 \\
(0.224)\end{array}$ & $\begin{array}{c}0.072 \\
(0.199)\end{array}$ & $\begin{array}{c}0.094 \\
(0.187)\end{array}$ \\
\hline Average Distance to Nearest Waterway & & & $\begin{array}{c}0.249 \\
(0.184)\end{array}$ & $\begin{array}{l}0.378^{* *} \\
(0.177)\end{array}$ & $\begin{array}{c}0.166 \\
(0.160)\end{array}$ & $\begin{array}{l}-0.054 \\
(0.174)\end{array}$ & $\begin{array}{c}0.050 \\
(0.157)\end{array}$ \\
\hline Percentage of Arable Land & & & $\begin{array}{l}-0.005 \\
(0.005)\end{array}$ & $\begin{array}{l}-0.003 \\
(0.005)\end{array}$ & $\begin{array}{l}-0.005 \\
(0.005)\end{array}$ & $\begin{array}{l}-0.005 \\
(0.005)\end{array}$ & $\begin{array}{l}-0.006 \\
(0.007)\end{array}$ \\
\hline Temperature & & & & $\begin{array}{c}0.032^{* * *} \\
(0.011)\end{array}$ & $\begin{array}{c}0.002 \\
(0.018)\end{array}$ & $\begin{array}{c}0.010 \\
(0.019)\end{array}$ & $\begin{array}{c}0.020 \\
(0.017)\end{array}$ \\
\hline Colony & & & & & & & $\begin{array}{c}-0.421^{*} \\
(0.242) \\
\end{array}$ \\
\hline Continental FE & No & No & No & No & Yes & Yes & Yes \\
\hline Legal Origin FE & No & No & No & No & No & Yes & Yes \\
\hline $\begin{array}{l}N \\
\text { Adiusted } R^{2}\end{array}$ & $\begin{array}{c}140 \\
0.062\end{array}$ & $\begin{array}{c}140 \\
0.067\end{array}$ & $\begin{array}{c}140 \\
0.133\end{array}$ & $\begin{array}{c}140 \\
0.175\end{array}$ & $\begin{array}{c}140 \\
0.284\end{array}$ & $\begin{array}{c}140 \\
0.367\end{array}$ & $\begin{array}{c}126 \\
0.378\end{array}$ \\
\hline
\end{tabular}

This table presents the results of a series of OLS regression analyses, on the contemporary country level, of a measure of contemporary autocracy on predicted genetic diversity, conditional on a range of control variables. Specifications marked with "Continental FE" accounts for sub-Saharan Africa, Latin America, and continental fixed effects. Heteroscedasticity-consistent standard errors are reported in parentheses. ${ }^{* * *}$ Significant at the 1 percent level. ${ }^{* *}$ Significant at the 5 percent level. * Significant at the 10 percent level. 
Table B.43: Predicted Diversity and Autocracy — Accounting for Irrigation Potential

\begin{tabular}{|c|c|c|c|c|c|c|c|}
\hline & \multicolumn{7}{|c|}{ Log Autocracy } \\
\hline & $(1)$ & $(2)$ & (3) & (4) & $(5)$ & $(6)$ & $(7)$ \\
\hline Predicted Genetic Diversity & $\begin{array}{c}9.071^{* * *} \\
(1.801)\end{array}$ & $\begin{array}{c}9.527^{* * *} \\
(1.831)\end{array}$ & $\begin{array}{c}7.273^{* * *} \\
(1.946)\end{array}$ & $\begin{array}{c}7.088^{* * *} \\
(1.849)\end{array}$ & $\begin{array}{c}6.830^{* *} \\
(3.040)\end{array}$ & $\begin{array}{l}6.921^{* *} \\
(2.684)\end{array}$ & $\begin{array}{c}7.054^{* * *} \\
(2.690)\end{array}$ \\
\hline Log Percentage of Area Equipped for Irrigation & $\begin{array}{c}0.067 \\
(0.079)\end{array}$ & $\begin{array}{c}0.143^{*} \\
(0.081)\end{array}$ & $\begin{array}{c}0.409^{* * *} \\
(0.095)\end{array}$ & $\begin{array}{c}0.345^{* * *} \\
(0.102)\end{array}$ & $\begin{array}{c}0.021 \\
(0.108)\end{array}$ & $\begin{array}{c}0.087 \\
(0.106)\end{array}$ & $\begin{array}{c}0.078 \\
(0.106)\end{array}$ \\
\hline Log Absolute Latitude & & $\begin{array}{c}-0.196^{* * *} \\
(0.052)\end{array}$ & $\begin{array}{c}-0.151^{* * *} \\
(0.055)\end{array}$ & $\begin{array}{c}0.020 \\
(0.083)\end{array}$ & $\begin{array}{l}-0.051 \\
(0.081)\end{array}$ & $\begin{array}{l}-0.049 \\
(0.072)\end{array}$ & $\begin{array}{l}-0.056 \\
(0.072)\end{array}$ \\
\hline Soil Fertility & & & $\begin{array}{c}-1.227^{* * *} \\
(0.425)\end{array}$ & $\begin{array}{c}-1.118^{* * *} \\
(0.420)\end{array}$ & $\begin{array}{l}-0.441 \\
(0.383)\end{array}$ & $\begin{array}{c}-0.861^{* *} \\
(0.382)\end{array}$ & $\begin{array}{r}-0.845^{* *} \\
(0.383)\end{array}$ \\
\hline Roughness & & & $\begin{array}{c}-1.640^{* *} \\
(0.738)\end{array}$ & $\begin{array}{l}-1.288^{*} \\
(0.772)\end{array}$ & $\begin{array}{c}-0.889 \\
(0.746)\end{array}$ & $\begin{array}{l}-1.057 \\
(0.643)\end{array}$ & $\begin{array}{r}-1.127^{*} \\
(0.628)\end{array}$ \\
\hline Elevation & & & $\begin{array}{c}0.428^{* *} \\
(0.180)\end{array}$ & $\begin{array}{l}0.461^{* *} \\
(0.184)\end{array}$ & $\begin{array}{c}0.193 \\
(0.202)\end{array}$ & $\begin{array}{c}0.326^{*} \\
(0.183)\end{array}$ & $\begin{array}{l}0.320^{*} \\
(0.176)\end{array}$ \\
\hline Average Distance to Nearest Waterway & & & $\begin{array}{c}0.167 \\
(0.157)\end{array}$ & $\begin{array}{l}0.281^{*} \\
(0.164)\end{array}$ & $\begin{array}{c}0.154 \\
(0.150)\end{array}$ & $\begin{array}{l}-0.059 \\
(0.163)\end{array}$ & $\begin{array}{c}-0.081 \\
(0.166)\end{array}$ \\
\hline Percentage of Arable Land & & & $\begin{array}{c}-0.012^{* *} \\
(0.006)\end{array}$ & $\begin{array}{c}-0.008 \\
(0.006)\end{array}$ & $\begin{array}{l}-0.004 \\
(0.005)\end{array}$ & $\begin{array}{l}-0.005 \\
(0.005)\end{array}$ & $\begin{array}{l}-0.005 \\
(0.005)\end{array}$ \\
\hline Temperature & & & & $\begin{array}{l}0.028^{* *} \\
(0.011)\end{array}$ & $\begin{array}{c}0.012 \\
(0.017)\end{array}$ & $\begin{array}{c}0.019 \\
(0.017)\end{array}$ & $\begin{array}{c}0.025 \\
(0.017)\end{array}$ \\
\hline Colony & & & & & & & $\begin{array}{c}-0.290 \\
(0.249)\end{array}$ \\
\hline Continental FE & No & No & No & No & Yes & Yes & Yes \\
\hline Legal Origin FE & No & No & No & No & No & Yes & Yes \\
\hline$N$ & 145 & 145 & 145 & 145 & 145 & 145 & 145 \\
\hline Adjusted $R^{2}$ & 0.072 & 0.108 & 0.307 & 0.333 & 0.436 & 0.506 & 0.507 \\
\hline
\end{tabular}

This table presents the results of a series of 2SLS regression analyses, on the contemporary country level, of a measure of contemporary autocracy on predicted genetic diversity, instrumented by the migratory distance from East Africa to the country, conditional on a range of control variables. Specifications marked with "Continental FE" accounts for sub-Saharan Africa, Latin America, and continental fixed effects. Heteroscedasticity-consistent standard errors are reported in parentheses. *** Significant at the 1 percent level. ${ }^{* *}$ Significant at the 5 percent level. ${ }^{*}$ Significant at the 10 percent level.

This table establishes that the findings in Table 14 are robust to accounting for the irrigation potential. 
Table B.44: Predicted Diversity and Autocracy — Accounting for Percentage of Land near a Waterway

\begin{tabular}{|c|c|c|c|c|c|c|c|}
\hline & \multicolumn{7}{|c|}{ Log Autocracy } \\
\hline & $(1)$ & $(2)$ & $(3)$ & $(4)$ & $(5)$ & $(6)$ & (7) \\
\hline Predicted Genetic Diversity & $\begin{array}{c}6.945^{* * *} \\
(1.895)\end{array}$ & $\begin{array}{c}7.139^{* * *} \\
(1.938)\end{array}$ & $\begin{array}{c}6.120^{* * *} \\
(2.042)\end{array}$ & $\begin{array}{c}6.197^{* * *} \\
(2.029)\end{array}$ & $\begin{array}{c}6.847^{* *} \\
(3.051)\end{array}$ & $\begin{array}{l}7.018^{* *} \\
(2.684)\end{array}$ & $\begin{array}{c}7.163^{* * *} \\
(2.684)\end{array}$ \\
\hline Percentage of Land Near a Waterway & $\begin{array}{c}-0.662^{* * *} \\
(0.177)\end{array}$ & $\begin{array}{c}-0.608^{* * *} \\
(0.186)\end{array}$ & $\begin{array}{l}-0.110 \\
(0.323)\end{array}$ & $\begin{array}{c}0.093 \\
(0.304)\end{array}$ & $\begin{array}{c}0.021 \\
(0.272)\end{array}$ & $\begin{array}{c}0.125 \\
(0.259)\end{array}$ & $\begin{array}{c}0.149 \\
(0.264)\end{array}$ \\
\hline Log Absolute Latitude & & $\begin{array}{l}-0.099^{*} \\
(0.055)\end{array}$ & $\begin{array}{c}-0.055 \\
(0.057)\end{array}$ & $\begin{array}{c}0.159^{* *} \\
(0.078)\end{array}$ & $\begin{array}{c}-0.048 \\
(0.082)\end{array}$ & $\begin{array}{l}-0.035 \\
(0.074)\end{array}$ & $\begin{array}{c}-0.044 \\
(0.074)\end{array}$ \\
\hline Soil Fertility & & & $\begin{array}{c}-1.262^{* *} \\
(0.489)\end{array}$ & $\begin{array}{c}-1.131^{* *} \\
(0.472)\end{array}$ & $\begin{array}{c}-0.426 \\
(0.385)\end{array}$ & $\begin{array}{c}-0.780^{* *} \\
(0.391)\end{array}$ & $\begin{array}{c}-0.779^{*} \\
(0.394)\end{array}$ \\
\hline Roughness & & & $\begin{array}{l}-0.137 \\
(0.799)\end{array}$ & $\begin{array}{c}-0.144 \\
(0.800)\end{array}$ & $\begin{array}{c}-0.862 \\
(0.740)\end{array}$ & $\begin{array}{l}-0.981 \\
(0.656)\end{array}$ & $\begin{array}{c}-1.097^{*} \\
(0.654)\end{array}$ \\
\hline Elevation & & & $\begin{array}{c}0.258 \\
(0.248)\end{array}$ & $\begin{array}{l}0.422^{*} \\
(0.245)\end{array}$ & $\begin{array}{c}0.198 \\
(0.236)\end{array}$ & $\begin{array}{c}0.361 \\
(0.218)\end{array}$ & $\begin{array}{c}0.368^{*} \\
(0.214)\end{array}$ \\
\hline Average Distance to Nearest Waterway & & & $\begin{array}{c}0.170 \\
(0.202)\end{array}$ & $\begin{array}{c}0.386^{* *} \\
(0.195)\end{array}$ & $\begin{array}{c}0.161 \\
(0.166)\end{array}$ & $\begin{array}{l}-0.012 \\
(0.183)\end{array}$ & $\begin{array}{c}-0.028 \\
(0.185)\end{array}$ \\
\hline Percentage of Arable Land & & & $\begin{array}{l}-0.001 \\
(0.005)\end{array}$ & $\begin{array}{c}0.001 \\
(0.005)\end{array}$ & $\begin{array}{c}-0.003 \\
(0.005)\end{array}$ & $\begin{array}{l}-0.003 \\
(0.005)\end{array}$ & $\begin{array}{c}-0.004 \\
(0.005)\end{array}$ \\
\hline Temperature & & & & $\begin{array}{c}0.039^{* * *} \\
(0.011)\end{array}$ & $\begin{array}{c}0.013 \\
(0.017)\end{array}$ & $\begin{array}{c}0.022 \\
(0.018)\end{array}$ & $\begin{array}{c}0.029 \\
(0.018)\end{array}$ \\
\hline Colony & & & & & & & $\begin{array}{l}-0.315 \\
(0.248)\end{array}$ \\
\hline Continental FE & No & No & No & No & Yes & Yes & Yes \\
\hline Legal Origin FE & No & No & No & No & No & Yes & Yes \\
\hline $\mathrm{N}$ & 145 & 145 & 145 & 145 & 145 & 145 & 145 \\
\hline Adjusted $R^{2}$ & 0.149 & 0.155 & 0.203 & 0.264 & 0.436 & 0.504 & 0.506 \\
\hline
\end{tabular}

This table presents the results of a series of 2SLS regression analyses, on the contemporary country level, of a measure of contemporary autocracy on predicted genetic diversity, instrumented by the migratory distance from East Africa to the country, conditional on a range of control variables. Specifications marked with "Continental FE" accounts for sub-Saharan Africa, Latin America, and continental fixed effects. Heteroscedasticity-consistent standard errors are reported in parentheses. ${ }^{* * *}$ Significant at the 1 percent level. ${ }^{* *}$ Significant at the 5 percent level. ${ }^{*}$ Significant at the 10 percent level.

This table establishes that the findings in Table 14 are robust to accounting for the percentage of land near a waterway. 
Table B.45: Predicted Diversity and Autocracy — Accounting for the Inequality in Land Suitability

\begin{tabular}{|c|c|c|c|c|c|c|c|}
\hline & \multicolumn{7}{|c|}{ Log Autocracy } \\
\hline & $(1)$ & $(2)$ & $(3)$ & (4) & (5) & (6) & $(7)$ \\
\hline Predicted Genetic Diversity & $\begin{array}{c}8.363^{* * *} \\
(1.823)\end{array}$ & $\begin{array}{c}8.408^{* * *} \\
(1.864)\end{array}$ & $\begin{array}{c}6.026^{* * *} \\
(2.059)\end{array}$ & $\begin{array}{c}6.067^{* * *} \\
(2.034)\end{array}$ & $\begin{array}{l}7.300^{* *} \\
(3.115)\end{array}$ & $\begin{array}{c}7.393^{* * *} \\
(2.751)\end{array}$ & $\begin{array}{c}7.518^{* * *} \\
(2.747)\end{array}$ \\
\hline Land suitability Gini & $\begin{array}{c}0.472 \\
(0.297)\end{array}$ & $\begin{array}{l}0.510^{*} \\
(0.290)\end{array}$ & $\begin{array}{c}-0.992^{* *} \\
(0.410)\end{array}$ & $\begin{array}{l}-0.696^{*} \\
(0.416)\end{array}$ & $\begin{array}{l}-0.574 \\
(0.374)\end{array}$ & $\begin{array}{l}-0.336 \\
(0.364)\end{array}$ & $\begin{array}{c}-0.278 \\
(0.374)\end{array}$ \\
\hline Log Absolute Latitude & & $\begin{array}{c}-0.160^{* * *} \\
(0.052)\end{array}$ & $\begin{array}{l}-0.001 \\
(0.055)\end{array}$ & $\begin{array}{l}0.173^{* *} \\
(0.077)\end{array}$ & $\begin{array}{l}-0.024 \\
(0.081)\end{array}$ & $\begin{array}{l}-0.017 \\
(0.074)\end{array}$ & $\begin{array}{c}-0.026 \\
(0.074)\end{array}$ \\
\hline Soil Fertility & & & $\begin{array}{c}-2.183^{* * *} \\
(0.488)\end{array}$ & $\begin{array}{c}-1.864^{* * *} \\
(0.483)\end{array}$ & $\begin{array}{c}-1.058^{* *} \\
(0.468)\end{array}$ & $\begin{array}{c}-1.206^{* * *} \\
(0.455)\end{array}$ & $\begin{array}{c}-1.176^{* *} \\
(0.453)\end{array}$ \\
\hline Roughness & & & $\begin{array}{c}0.226 \\
(0.706)\end{array}$ & $\begin{array}{c}0.375 \\
(0.714)\end{array}$ & $\begin{array}{l}-0.512 \\
(0.699)\end{array}$ & $\begin{array}{l}-0.559 \\
(0.614)\end{array}$ & $\begin{array}{c}-0.639 \\
(0.598)\end{array}$ \\
\hline Elevation & & & $\begin{array}{c}0.319 \\
(0.203)\end{array}$ & $\begin{array}{c}0.359^{*} \\
(0.203)\end{array}$ & $\begin{array}{c}0.182 \\
(0.210)\end{array}$ & $\begin{array}{c}0.277 \\
(0.186)\end{array}$ & $\begin{array}{c}0.267 \\
(0.179)\end{array}$ \\
\hline Average Distance to Nearest Waterway & & & $\begin{array}{l}0.362^{* *} \\
(0.174)\end{array}$ & $\begin{array}{c}0.450^{* * *} \\
(0.170)\end{array}$ & $\begin{array}{c}0.228 \\
(0.147)\end{array}$ & $\begin{array}{c}0.003 \\
(0.164)\end{array}$ & $\begin{array}{c}-0.027 \\
(0.168)\end{array}$ \\
\hline Percentage of Arable Land & & & $\begin{array}{l}-0.001 \\
(0.005)\end{array}$ & $\begin{array}{c}0.002 \\
(0.005)\end{array}$ & $\begin{array}{l}-0.002 \\
(0.005)\end{array}$ & $\begin{array}{l}-0.002 \\
(0.005)\end{array}$ & $\begin{array}{c}-0.002 \\
(0.005)\end{array}$ \\
\hline Temperature & & & & $\begin{array}{c}0.034^{* * *} \\
(0.011)\end{array}$ & $\begin{array}{c}0.006 \\
(0.017)\end{array}$ & $\begin{array}{c}0.017 \\
(0.018)\end{array}$ & $\begin{array}{c}0.023 \\
(0.018)\end{array}$ \\
\hline Colony & & & & & & & $\begin{array}{l}-0.288 \\
(0.251)\end{array}$ \\
\hline Continental FE & No & No & No & No & Yes & Yes & Yes \\
\hline Legal Origin FE & No & No & No & No & No & Yes & Yes \\
\hline $\mathrm{N}$ & 144 & 144 & 144 & 144 & 144 & 144 & 144 \\
\hline Adjusted $R^{2}$ & 0.085 & 0.111 & 0.257 & 0.300 & 0.449 & 0.509 & 0.510 \\
\hline
\end{tabular}

This table presents the results of a series of 2SLS regression analyses, on the contemporary country level, of a measure of contemporary autocracy on predicted genetic diversity, instrumented by the migratory distance from East Africa to the country, conditional on a range of control variables. Specifications marked with "Continental FE" accounts for sub-Saharan Africa, Latin America, and continental fixed effects. Heteroscedasticity-consistent standard errors are reported in parentheses. *** Significant at the 1 percent level. ${ }^{* *}$ Significant at the 5 percent level. ${ }^{*}$ Significant at the 10 percent level.

This table establishes that the findings in Table 14 are robust to accounting for the inequality of land suitability (i.e., the Gini coefficient of land suitability). 
Table B.46: Predicted Diversity and Autocracy — Accounting for Percentages of Population Living in Various Climate Zones

\begin{tabular}{|c|c|c|c|c|c|c|c|}
\hline & \multicolumn{7}{|c|}{ Log Autocracy } \\
\hline & $(1)$ & $(2)$ & (3) & (4) & $(5)$ & (6) & (7) \\
\hline Predicted Genetic Diversity & $\begin{array}{c}8.454^{* * *} \\
(1.950)\end{array}$ & $\begin{array}{c}8.432^{* * *} \\
(2.007)\end{array}$ & $\begin{array}{c}7.465^{* * *} \\
(2.205)\end{array}$ & $\begin{array}{c}7.105^{* * *} \\
(2.209)\end{array}$ & $\begin{array}{l}6.913^{* *} \\
(3.189)\end{array}$ & $\begin{array}{l}7.231^{* *} \\
(2.868)\end{array}$ & $\begin{array}{l}7.438^{* *} \\
(2.870)\end{array}$ \\
\hline Percentage of Population Living in Temperate Zones & $\begin{array}{c}-1.131^{* * *} \\
(0.175)\end{array}$ & $\begin{array}{c}-1.128^{* * *} \\
(0.193)\end{array}$ & $\begin{array}{c}-0.900^{* * *} \\
(0.220)\end{array}$ & $\begin{array}{c}-0.716^{* *} \\
(0.308)\end{array}$ & $\begin{array}{l}-0.101 \\
(0.378)\end{array}$ & $\begin{array}{c}0.126 \\
(0.391)\end{array}$ & $\begin{array}{l}0.175 \\
(0.385)\end{array}$ \\
\hline Percentage of Population Living in Tropical Zones & $\begin{array}{l}-0.355 \\
(0.465)\end{array}$ & $\begin{array}{l}-0.361 \\
(0.496)\end{array}$ & $\begin{array}{l}-0.247 \\
(0.520)\end{array}$ & $\begin{array}{l}-0.211 \\
(0.519)\end{array}$ & $\begin{array}{c}0.067 \\
(0.438)\end{array}$ & $\begin{array}{c}-0.068 \\
(0.368)\end{array}$ & $\begin{array}{l}-0.119 \\
(0.366)\end{array}$ \\
\hline Percentage of Population Living in Tropical and Subtropical Zones & $\begin{array}{l}-0.125 \\
(0.485)\end{array}$ & $\begin{array}{l}-0.125 \\
(0.487)\end{array}$ & $\begin{array}{l}-0.008 \\
(0.487)\end{array}$ & $\begin{array}{l}-0.021 \\
(0.487)\end{array}$ & $\begin{array}{l}-0.026 \\
(0.392)\end{array}$ & $\begin{array}{c}0.115 \\
(0.332)\end{array}$ & $\begin{array}{c}0.162 \\
(0.329)\end{array}$ \\
\hline Log Absolute Latitude & & $\begin{array}{l}-0.004 \\
(0.094)\end{array}$ & $\begin{array}{c}0.059 \\
(0.099)\end{array}$ & $\begin{array}{c}0.097 \\
(0.106)\end{array}$ & $\begin{array}{l}-0.031 \\
(0.102)\end{array}$ & $\begin{array}{l}-0.032 \\
(0.091)\end{array}$ & $\begin{array}{l}-0.046 \\
(0.091)\end{array}$ \\
\hline Soil Fertility & & & $\begin{array}{l}-0.881^{*} \\
(0.482)\end{array}$ & $\begin{array}{c}-0.902^{*} \\
(0.478)\end{array}$ & $\begin{array}{l}-0.403 \\
(0.386)\end{array}$ & $\begin{array}{c}-0.802^{* *} \\
(0.387)\end{array}$ & $\begin{array}{c}-0.810^{* *} \\
(0.393)\end{array}$ \\
\hline Roughness & & & $\begin{array}{c}0.034 \\
(0.718)\end{array}$ & $\begin{array}{c}0.042 \\
(0.727)\end{array}$ & $\begin{array}{l}-0.847 \\
(0.724)\end{array}$ & $\begin{array}{l}-0.893 \\
(0.655)\end{array}$ & $\begin{array}{l}-0.989 \\
(0.644)\end{array}$ \\
\hline Elevation & & & $\begin{array}{c}0.102 \\
(0.208)\end{array}$ & $\begin{array}{c}0.165 \\
(0.227)\end{array}$ & $\begin{array}{c}0.184 \\
(0.218)\end{array}$ & $\begin{array}{c}0.323 \\
(0.201)\end{array}$ & $\begin{array}{l}0.321^{*} \\
(0.193)\end{array}$ \\
\hline Average Distance to Nearest Waterway & & & $\begin{array}{c}0.085 \\
(0.156)\end{array}$ & $\begin{array}{c}0.159 \\
(0.177)\end{array}$ & $\begin{array}{c}0.130 \\
(0.150)\end{array}$ & $\begin{array}{c}-0.022 \\
(0.166)\end{array}$ & $\begin{array}{l}-0.035 \\
(0.169)\end{array}$ \\
\hline Percentage of Arable Land & & & $\begin{array}{c}0.002 \\
(0.005)\end{array}$ & $\begin{array}{c}0.002 \\
(0.005)\end{array}$ & $\begin{array}{l}-0.003 \\
(0.005)\end{array}$ & $\begin{array}{l}-0.003 \\
(0.005)\end{array}$ & $\begin{array}{l}-0.003 \\
(0.005)\end{array}$ \\
\hline Temperature & & & & $\begin{array}{c}0.013 \\
(0.015)\end{array}$ & $\begin{array}{c}0.010 \\
(0.017)\end{array}$ & $\begin{array}{c}0.024 \\
(0.019)\end{array}$ & $\begin{array}{c}0.032 \\
(0.020)\end{array}$ \\
\hline Colony & & & & & & & $\begin{array}{l}-0.329 \\
(0.247)\end{array}$ \\
\hline Continental FE & No & No & No & No & Yes & Yes & Yes \\
\hline Legal Origin FE & No & No & No & No & No & Yes & Yes \\
\hline $\mathrm{N}$ & 145 & 145 & 145 & 145 & 145 & 145 & 145 \\
\hline Adjusted $R^{2}$ & 0.284 & 0.279 & 0.282 & 0.280 & 0.428 & 0.496 & 0.499 \\
\hline
\end{tabular}

This table presents the results of a series of 2SLS regression analyses, on the contemporary country level, of a measure of contemporary autocracy on predicted genetic diversity, instrumented by the migratory distance from East Africa to the country, conditional on a range of control variables. Specifications marked with "Continental FE" accounts for sub-Saharan Africa, Latin America, and continental fixed effects. Heteroscedasticity-consistent standard errors are reported in parentheses. ${ }^{* *}$ Significant at the 1 percent level. ${ }^{* *}$ Significant at the 5 percent level. ${ }^{*}$ Significant at the 10 percent level.

This table establishes that the findings in Table 14 are robust to accounting for the percentages of population living in various climate zones. 
Table B.47: Predicted Diversity and Autocracy — Accounting for Colonizer Nation

\begin{tabular}{|c|c|c|c|c|c|c|}
\hline & \multicolumn{6}{|c|}{ Log Autocracy } \\
\hline & (1) & $(2)$ & $(3)$ & (4) & $(5)$ & (6) \\
\hline Predicted Genetic Diversity & $\begin{array}{l}5.762^{* *} \\
(2.628)\end{array}$ & $\begin{array}{l}5.521^{* *} \\
(2.592)\end{array}$ & $\begin{array}{l}4.916^{*} \\
(2.606)\end{array}$ & $\begin{array}{l}4.671^{*} \\
(2.631)\end{array}$ & $\begin{array}{l}8.101^{* *} \\
(3.293)\end{array}$ & $\begin{array}{l}6.799^{* *} \\
(3.084)\end{array}$ \\
\hline British Colony & $\begin{array}{l}0.412^{*} \\
(0.226)\end{array}$ & $\begin{array}{l}0.444^{* *} \\
(0.218)\end{array}$ & $\begin{array}{c}0.234 \\
(0.237)\end{array}$ & $\begin{array}{c}0.247 \\
(0.229)\end{array}$ & $\begin{array}{l}-0.143 \\
(0.261)\end{array}$ & $\begin{array}{c}0.168 \\
(0.311)\end{array}$ \\
\hline French Colony & $\begin{array}{c}0.670^{* * *} \\
(0.242)\end{array}$ & $\begin{array}{c}0.670^{* * *} \\
(0.238)\end{array}$ & $\begin{array}{l}0.504^{*} \\
(0.257)\end{array}$ & $\begin{array}{c}0.406 \\
(0.267)\end{array}$ & $\begin{array}{c}0.049 \\
(0.256)\end{array}$ & $\begin{array}{l}-0.030 \\
(0.266)\end{array}$ \\
\hline Other Colony & $\begin{array}{c}0.306 \\
(0.229)\end{array}$ & $\begin{array}{l}0.440^{* *} \\
(0.222)\end{array}$ & $\begin{array}{c}0.345 \\
(0.243)\end{array}$ & $\begin{array}{l}0.630^{* *} \\
(0.245)\end{array}$ & $\begin{array}{c}0.252 \\
(0.261)\end{array}$ & $\begin{array}{c}0.100 \\
(0.274)\end{array}$ \\
\hline Non-colony & $\begin{array}{c}0.039 \\
(0.231)\end{array}$ & $\begin{array}{c}0.185 \\
(0.228)\end{array}$ & $\begin{array}{c}0.054 \\
(0.220)\end{array}$ & $\begin{array}{c}0.323 \\
(0.214)\end{array}$ & $\begin{array}{c}0.050 \\
(0.241)\end{array}$ & $\begin{array}{c}0.391 \\
(0.262)\end{array}$ \\
\hline Log Absolute Latitude & & $\begin{array}{c}-0.149^{* * *} \\
(0.055)\end{array}$ & $\begin{array}{l}-0.062 \\
(0.056)\end{array}$ & $\begin{array}{l}0.145^{*} \\
(0.077)\end{array}$ & $\begin{array}{l}-0.033 \\
(0.080)\end{array}$ & $\begin{array}{l}-0.034 \\
(0.075)\end{array}$ \\
\hline Soil Fertility & & & $\begin{array}{c}-1.093^{* *} \\
(0.511)\end{array}$ & $\begin{array}{l}-0.868^{*} \\
(0.484)\end{array}$ & $\begin{array}{l}-0.444 \\
(0.387)\end{array}$ & $\begin{array}{l}-0.755^{*} \\
(0.412)\end{array}$ \\
\hline Roughness & & & $\begin{array}{l}-0.263 \\
(0.740)\end{array}$ & $\begin{array}{l}-0.232 \\
(0.737)\end{array}$ & $\begin{array}{l}-1.003 \\
(0.684)\end{array}$ & $\begin{array}{l}-0.764 \\
(0.617)\end{array}$ \\
\hline Elevation & & & $\begin{array}{c}0.294 \\
(0.200)\end{array}$ & $\begin{array}{l}0.348^{*} \\
(0.196)\end{array}$ & $\begin{array}{c}0.193 \\
(0.200)\end{array}$ & $\begin{array}{c}0.217 \\
(0.193)\end{array}$ \\
\hline Average Distance to Nearest Waterway & & & $\begin{array}{c}0.102 \\
(0.183)\end{array}$ & $\begin{array}{c}0.259 \\
(0.173)\end{array}$ & $\begin{array}{c}0.077 \\
(0.155)\end{array}$ & $\begin{array}{l}-0.100 \\
(0.163)\end{array}$ \\
\hline Percentage of Arable Land & & & $\begin{array}{l}-0.004 \\
(0.005)\end{array}$ & $\begin{array}{l}-0.004 \\
(0.005)\end{array}$ & $\begin{array}{l}-0.005 \\
(0.005)\end{array}$ & $\begin{array}{l}-0.004 \\
(0.005)\end{array}$ \\
\hline Temperature & & & & $\begin{array}{c}0.047^{* * *} \\
(0.011)\end{array}$ & $\begin{array}{c}0.020 \\
(0.016)\end{array}$ & $\begin{array}{c}0.022 \\
(0.017)\end{array}$ \\
\hline Continental FE & No & No & No & No & Yes & Yes \\
\hline Legal Origin FE & No & No & No & No & No & Yes \\
\hline $\begin{array}{l}\mathrm{N} \\
\text { Adjusted } R^{2}\end{array}$ & $\begin{array}{c}142 \\
0.119\end{array}$ & $\begin{array}{c}142 \\
0.136\end{array}$ & $\begin{array}{c}142 \\
0.223\end{array}$ & $\begin{array}{c}142 \\
0.298\end{array}$ & $\begin{array}{c}142 \\
0.448\end{array}$ & $\begin{array}{c}142 \\
0.511\end{array}$ \\
\hline
\end{tabular}

This table establishes that the findings in Table 14 are robust to accounting for colonizer nation. 
Table B.48: Predicted Diversity and Autocracy — Accounting for Colonial Duration

\begin{tabular}{|c|c|c|c|c|c|c|c|}
\hline & \multicolumn{7}{|c|}{ Log Autocracy } \\
\hline & (1) & $(2)$ & $(3)$ & $(4)$ & $(5)$ & $(6)$ & $(7)$ \\
\hline Predicted Genetic Diversity & $\begin{array}{c}7.149^{* * *} \\
(2.069)\end{array}$ & $\begin{array}{c}6.389^{* * *} \\
(2.147)\end{array}$ & $\begin{array}{l}4.330^{*} \\
(2.379)\end{array}$ & $\begin{array}{c}3.691 \\
(2.270)\end{array}$ & $\begin{array}{c}5.794^{*} \\
(3.078)\end{array}$ & $\begin{array}{l}6.029^{* *} \\
(2.742)\end{array}$ & $\begin{array}{l}6.137^{* *} \\
(2.743)\end{array}$ \\
\hline Colonial Duration & $\begin{array}{c}-0.073^{* *} \\
(0.033)\end{array}$ & $\begin{array}{c}-0.112^{* * *} \\
(0.033)\end{array}$ & $\begin{array}{r}-0.087^{* *} \\
(0.035)\end{array}$ & $\begin{array}{c}-0.116^{* * *} \\
(0.033)\end{array}$ & $\begin{array}{c}-0.148^{* * *} \\
(0.032)\end{array}$ & $\begin{array}{c}-0.121^{* * *} \\
(0.034)\end{array}$ & $\begin{array}{c}-0.115^{\text {*** }} \\
(0.036)\end{array}$ \\
\hline Log Absolute Latitude & & $\begin{array}{c}-0.208^{* * *} \\
(0.050)\end{array}$ & $\begin{array}{c}-0.111^{* *} \\
(0.054)\end{array}$ & $\begin{array}{c}0.123 \\
(0.075)\end{array}$ & $\begin{array}{l}-0.080 \\
(0.072)\end{array}$ & $\begin{array}{l}-0.064 \\
(0.068)\end{array}$ & $\begin{array}{l}-0.066 \\
(0.069)\end{array}$ \\
\hline Soil Fertility & & & $\begin{array}{c}-1.191^{* *} \\
(0.464)\end{array}$ & $\begin{array}{c}-0.974^{* *} \\
(0.431)\end{array}$ & $\begin{array}{c}-0.296 \\
(0.344)\end{array}$ & $\begin{array}{c}-0.602^{*} \\
(0.359)\end{array}$ & $\begin{array}{c}-0.609^{*} \\
(0.365)\end{array}$ \\
\hline Roughness & & & $\begin{array}{l}-0.352 \\
(0.692)\end{array}$ & $\begin{array}{c}-0.174 \\
(0.695)\end{array}$ & $\begin{array}{c}-1.094^{*} \\
(0.642)\end{array}$ & $\begin{array}{c}-1.062^{*} \\
(0.581)\end{array}$ & $\begin{array}{c}-1.092^{*} \\
(0.583)\end{array}$ \\
\hline Elevation & & & $\begin{array}{c}0.285 \\
(0.188)\end{array}$ & $\begin{array}{l}0.361^{*} \\
(0.190)\end{array}$ & $\begin{array}{c}0.207 \\
(0.195)\end{array}$ & $\begin{array}{l}0.302^{*} \\
(0.179)\end{array}$ & $\begin{array}{l}0.300^{*} \\
(0.177)\end{array}$ \\
\hline Average Distance to Nearest Waterway & & & $\begin{array}{c}0.195 \\
(0.178)\end{array}$ & $\begin{array}{l}0.365^{* *} \\
(0.172)\end{array}$ & $\begin{array}{c}0.121 \\
(0.149)\end{array}$ & $\begin{array}{l}-0.060 \\
(0.161)\end{array}$ & $\begin{array}{l}-0.069 \\
(0.164)\end{array}$ \\
\hline Percentage of Arable Land & & & $\begin{array}{l}-0.001 \\
(0.005)\end{array}$ & $\begin{array}{c}0.001 \\
(0.004)\end{array}$ & $\begin{array}{l}-0.002 \\
(0.004)\end{array}$ & $\begin{array}{l}-0.002 \\
(0.004)\end{array}$ & $\begin{array}{l}-0.002 \\
(0.004)\end{array}$ \\
\hline Temperature & & & & $\begin{array}{c}0.044^{* * *} \\
(0.010)\end{array}$ & $\begin{array}{c}0.021 \\
(0.016)\end{array}$ & $\begin{array}{c}0.027 \\
(0.017)\end{array}$ & $\begin{array}{c}0.029 \\
(0.018)\end{array}$ \\
\hline Colony & & & & & & & $\begin{array}{l}-0.132 \\
(0.265)\end{array}$ \\
\hline Continental FE & No & No & No & No & Yes & Yes & Yes \\
\hline Legal Origin FE & No & No & No & No & No & Yes & Yes \\
\hline $\mathrm{N}$ & 145 & 145 & 145 & 145 & 145 & 145 & 145 \\
\hline Adjusted $R^{2}$ & 0.086 & 0.129 & 0.226 & 0.306 & 0.481 & 0.533 & 0.530 \\
\hline
\end{tabular}

This table presents the results of a series of 2SLS regression analyses, on the contemporary country level, of a measure of contemporary autocracy on predicted genetic diversity, instrumented by the migratory distance from East Africa to the country, conditional on a range of control variables. Specifications marked with "Continental FE" accounts for sub-Saharan Africa, Latin America, and continental fixed effects. Heteroscedasticity-consistent standard errors are reported in parentheses. $* * *$ Significant at the 1 percent level. ** Significant at the 5 percent level. * Significant at the 10 percent level.

This table establishes that the findings in Table 14 are robust to accounting for colonial duration. 
Table B.49: Predicted Diversity and Autocracy — Accounting for GDP

\begin{tabular}{|c|c|c|c|c|c|c|c|}
\hline & \multicolumn{7}{|c|}{ Log Autocracy } \\
\hline & (1) & $(2)$ & (3) & (4) & (5) & (6) & (7) \\
\hline Predicted Genetic Diversity & $\begin{array}{c}7.605^{* * *} \\
(1.900)\end{array}$ & $\begin{array}{c}7.725^{* * *} \\
(1.978)\end{array}$ & $\begin{array}{c}5.671^{* * *} \\
(2.012)\end{array}$ & $\begin{array}{c}5.996^{* * *} \\
(2.126)\end{array}$ & $\begin{array}{l}7.595^{* *} \\
(2.981)\end{array}$ & $\begin{array}{l}6.897^{* *} \\
(2.719)\end{array}$ & $\begin{array}{l}6.300^{* *} \\
(3.023)\end{array}$ \\
\hline Log Income Per Capita in 2000 & $\begin{array}{c}-0.201^{* * *} \\
(0.057)\end{array}$ & $\begin{array}{c}-0.187^{* * *} \\
(0.070)\end{array}$ & $\begin{array}{c}-0.183^{* *} \\
(0.071)\end{array}$ & $\begin{array}{l}-0.097 \\
(0.102)\end{array}$ & $\begin{array}{l}-0.092 \\
(0.092)\end{array}$ & $\begin{array}{c}0.027 \\
(0.098)\end{array}$ & $\begin{array}{c}0.078 \\
(0.099)\end{array}$ \\
\hline Log Absolute Latitude & & $\begin{array}{l}-0.037 \\
(0.067)\end{array}$ & $\begin{array}{c}0.057 \\
(0.067)\end{array}$ & $\begin{array}{l}0.166^{* *} \\
(0.079)\end{array}$ & $\begin{array}{l}-0.050 \\
(0.082)\end{array}$ & $\begin{array}{l}-0.038 \\
(0.073)\end{array}$ & $\begin{array}{l}-0.050 \\
(0.078)\end{array}$ \\
\hline Soil Fertility & & & $\begin{array}{c}-1.375^{* * *} \\
(0.469)\end{array}$ & $\begin{array}{c}-1.196^{* * *} \\
(0.456)\end{array}$ & $\begin{array}{l}-0.472 \\
(0.387)\end{array}$ & $\begin{array}{l}-0.753^{*} \\
(0.383)\end{array}$ & $\begin{array}{l}-0.726 \\
(0.451)\end{array}$ \\
\hline Roughness & & & $\begin{array}{c}0.099 \\
(0.697)\end{array}$ & $\begin{array}{c}0.063 \\
(0.725)\end{array}$ & $\begin{array}{l}-0.873 \\
(0.675)\end{array}$ & $\begin{array}{l}-0.875 \\
(0.606)\end{array}$ & $\begin{array}{l}-0.736 \\
(0.568)\end{array}$ \\
\hline Elevation & & & $\begin{array}{c}0.134 \\
(0.205)\end{array}$ & $\begin{array}{c}0.271 \\
(0.232)\end{array}$ & $\begin{array}{c}0.137 \\
(0.204)\end{array}$ & $\begin{array}{c}0.315 \\
(0.194)\end{array}$ & $\begin{array}{l}0.364^{* *} \\
(0.174)\end{array}$ \\
\hline Average Distance to Nearest Waterway & & & $\begin{array}{c}0.147 \\
(0.185)\end{array}$ & $\begin{array}{c}0.288 \\
(0.195)\end{array}$ & $\begin{array}{c}0.104 \\
(0.155)\end{array}$ & $\begin{array}{l}-0.042 \\
(0.166)\end{array}$ & $\begin{array}{c}0.006 \\
(0.151)\end{array}$ \\
\hline Percentage of Arable Land & & & $\begin{array}{l}-0.003 \\
(0.005)\end{array}$ & $\begin{array}{l}-0.000 \\
(0.005)\end{array}$ & $\begin{array}{l}-0.005 \\
(0.005)\end{array}$ & $\begin{array}{l}-0.003 \\
(0.005)\end{array}$ & $\begin{array}{l}-0.004 \\
(0.006)\end{array}$ \\
\hline Temperature & & & & $\begin{array}{l}0.029^{*} \\
(0.016)\end{array}$ & $\begin{array}{c}0.007 \\
(0.018)\end{array}$ & $\begin{array}{c}0.021 \\
(0.019)\end{array}$ & $\begin{array}{c}0.032^{* *} \\
(0.016)\end{array}$ \\
\hline Colony & & & & & & & $\begin{array}{r}-0.460^{* *} \\
(0.198) \\
\end{array}$ \\
\hline Continental FE & No & No & No & No & Yes & Yes & Yes \\
\hline Legal Origin FE & No & No & No & No & No & Yes & Yes \\
\hline$N$ & 144 & 144 & 144 & 144 & 144 & 144 & 129 \\
\hline Adjusted $R^{2}$ & 0.154 & 0.150 & 0.252 & 0.276 & 0.441 & 0.496 & 0.528 \\
\hline
\end{tabular}

This table presents the results of a series of 2SLS regression analyses, on the contemporary country level, of a measure of contemporary autocracy on predicted genetic diversity, instrumented by the migratory distance from East Africa to the country, conditional on a range of control variables. Specifications marked with "Continental FE" accounts for sub-Saharan Africa, Latin America, and continental fixed effects. Heteroscedasticity-consistent standard errors are reported in parentheses. $* * *$ Significant at the 1 percent level. ${ }^{* *}$ Significant at the 5 percent level. * Significant at the 10 percent level.

This table establishes that the findings in Table 14 are robust to accounting for mid-period income per capita (i.e., income per capita in year 2000). 
Table B.50: Predicted Diversity and Autocracy — Accounting for Schooling

\begin{tabular}{|c|c|c|c|c|c|c|c|}
\hline & \multicolumn{7}{|c|}{ Log Autocracy } \\
\hline & $(1)$ & $(2)$ & $(3)$ & $(4)$ & $(5)$ & (6) & $(7)$ \\
\hline Predicted Genetic Diversity & $\begin{array}{c}7.913^{* * *} \\
(1.656)\end{array}$ & $\begin{array}{c}7.710^{* * *} \\
(1.678)\end{array}$ & $\begin{array}{c}5.727^{* * *} \\
(1.960)\end{array}$ & $\begin{array}{c}6.132^{* * *} \\
(2.074)\end{array}$ & $\begin{array}{c}8.162^{* * *} \\
(2.917)\end{array}$ & $\begin{array}{c}8.646^{* * *} \\
(2.470)\end{array}$ & $\begin{array}{c}8.578^{* * *} \\
(2.465)\end{array}$ \\
\hline Years of schooling & $\begin{array}{c}-0.120^{* * *} \\
(0.019)\end{array}$ & $\begin{array}{c}-0.129^{* * *} \\
(0.026)\end{array}$ & $\begin{array}{c}-0.114^{* * *} \\
(0.024)\end{array}$ & $\begin{array}{c}-0.082^{* *} \\
(0.039)\end{array}$ & $\begin{array}{c}-0.081^{* *} \\
(0.037)\end{array}$ & $\begin{array}{c}-0.097^{* * *} \\
(0.031)\end{array}$ & $\begin{array}{c}-0.098^{* * *} \\
(0.031)\end{array}$ \\
\hline Log Absolute Latitude & & $\begin{array}{c}0.050 \\
(0.067)\end{array}$ & $\begin{array}{c}0.081 \\
(0.064)\end{array}$ & $\begin{array}{c}0.137 \\
(0.086)\end{array}$ & $\begin{array}{c}-0.051 \\
(0.087)\end{array}$ & $\begin{array}{l}-0.040 \\
(0.082)\end{array}$ & $\begin{array}{l}-0.038 \\
(0.083)\end{array}$ \\
\hline Soil Fertility & & & $\begin{array}{l}-0.630 \\
(0.432)\end{array}$ & $\begin{array}{l}-0.647 \\
(0.433)\end{array}$ & $\begin{array}{c}0.027 \\
(0.335)\end{array}$ & $\begin{array}{l}-0.249 \\
(0.319)\end{array}$ & $\begin{array}{l}-0.243 \\
(0.319)\end{array}$ \\
\hline Roughness & & & $\begin{array}{l}-0.385 \\
(0.651)\end{array}$ & $\begin{array}{l}-0.336 \\
(0.676)\end{array}$ & $\begin{array}{c}-0.995^{*} \\
(0.581)\end{array}$ & $\begin{array}{l}-0.633 \\
(0.485)\end{array}$ & $\begin{array}{l}-0.604 \\
(0.498)\end{array}$ \\
\hline Elevation & & & $\begin{array}{c}0.237 \\
(0.220)\end{array}$ & $\begin{array}{c}0.305 \\
(0.217)\end{array}$ & $\begin{array}{c}0.173 \\
(0.180)\end{array}$ & $\begin{array}{c}0.175 \\
(0.154)\end{array}$ & $\begin{array}{c}0.177 \\
(0.156)\end{array}$ \\
\hline Average Distance to Nearest Waterway & & & $\begin{array}{c}0.221 \\
(0.230)\end{array}$ & $\begin{array}{c}0.281 \\
(0.237)\end{array}$ & $\begin{array}{c}0.146 \\
(0.165)\end{array}$ & $\begin{array}{l}-0.051 \\
(0.170)\end{array}$ & $\begin{array}{l}-0.046 \\
(0.172)\end{array}$ \\
\hline Percentage of Arable Land & & & $\begin{array}{l}-0.001 \\
(0.005)\end{array}$ & $\begin{array}{l}-0.000 \\
(0.005)\end{array}$ & $\begin{array}{l}-0.005 \\
(0.005)\end{array}$ & $\begin{array}{l}-0.007 \\
(0.005)\end{array}$ & $\begin{array}{l}-0.007 \\
(0.005)\end{array}$ \\
\hline Temperature & & & & $\begin{array}{c}0.018 \\
(0.016)\end{array}$ & $\begin{array}{l}-0.005 \\
(0.018)\end{array}$ & $\begin{array}{l}-0.000 \\
(0.017)\end{array}$ & $\begin{array}{l}-0.002 \\
(0.017)\end{array}$ \\
\hline Colony & & & & & & & $\begin{array}{c}0.104 \\
(0.218) \\
\end{array}$ \\
\hline Continental FE & No & No & No & No & Yes & Yes & Yes \\
\hline Legal Origin FE & No & No & No & No & No & Yes & Yes \\
\hline $\mathrm{N}$ & 110 & 110 & 110 & 110 & 110 & 110 & 110 \\
\hline Adjusted $R^{2}$ & 0.299 & 0.295 & 0.340 & 0.341 & 0.483 & 0.557 & 0.553 \\
\hline
\end{tabular}

This table presents the results of a series of 2SLS regression analyses, on the contemporary country level, of a measure of contemporary autocracy on predicted genetic diversity, instrumented by the migratory distance from East Africa to the country, conditional on a range of control variables. Specifications marked with "Continental FE" accounts for sub-Saharan Africa, Latin America, and continental fixed effects. Heteroscedasticity-consistent standard errors are reported in parentheses. $* * *$ Significant at the 1 percent level. ${ }^{* *}$ Significant at the 5 percent level. ${ }^{*}$ Significant at the 10 percent level.

This table establishes that the findings in Table 14 are robust to accounting for years of schooling. 
Table B.51: Predicted Diversity and Autocracy — Accounting for Population Density in 1500

\begin{tabular}{|c|c|c|c|c|c|c|c|}
\hline & \multicolumn{7}{|c|}{ Log Autocracy } \\
\hline & $(1)$ & $(2)$ & $(3)$ & $(4)$ & $(5)$ & (6) & $(7)$ \\
\hline Predicted Genetic Diversity & $\begin{array}{c}8.928^{* * *} \\
(1.883)\end{array}$ & $\begin{array}{c}8.988^{* * *} \\
(1.904)\end{array}$ & $\begin{array}{c}6.247^{* * *} \\
(2.037)\end{array}$ & $\begin{array}{c}6.260^{* * *} \\
(2.018)\end{array}$ & $\begin{array}{l}6.253^{* *} \\
(3.047)\end{array}$ & $\begin{array}{c}7.275^{* * *} \\
(2.720)\end{array}$ & $\begin{array}{c}7.366^{\text {*** }} \\
(2.734)\end{array}$ \\
\hline Population Density in $1500 \mathrm{CE}$ & $\begin{array}{c}-0.020^{* * *} \\
(0.006)\end{array}$ & $\begin{array}{c}-0.017^{* * *} \\
(0.006)\end{array}$ & $\begin{array}{l}-0.008 \\
(0.006)\end{array}$ & $\begin{array}{l}-0.004 \\
(0.006)\end{array}$ & $\begin{array}{c}-0.013^{* *} \\
(0.006)\end{array}$ & $\begin{array}{c}0.001 \\
(0.009)\end{array}$ & $\begin{array}{c}0.001 \\
(0.009)\end{array}$ \\
\hline Log Absolute Latitude & & $\begin{array}{c}-0.121^{* *} \\
(0.053)\end{array}$ & $\begin{array}{l}-0.060 \\
(0.055)\end{array}$ & $\begin{array}{c}0.153^{*} \\
(0.078)\end{array}$ & $\begin{array}{c}-0.065 \\
(0.083)\end{array}$ & $\begin{array}{l}-0.040 \\
(0.073)\end{array}$ & $\begin{array}{l}-0.047 \\
(0.073)\end{array}$ \\
\hline Soil Fertility & & & $\begin{array}{c}-1.231^{* *} \\
(0.493)\end{array}$ & $\begin{array}{c}-1.052^{* *} \\
(0.467)\end{array}$ & $\begin{array}{l}-0.341 \\
(0.374)\end{array}$ & $\begin{array}{c}-0.682^{*} \\
(0.371)\end{array}$ & $\begin{array}{c}-0.685^{*} \\
(0.375)\end{array}$ \\
\hline Roughness & & & $\begin{array}{l}-0.195 \\
(0.710)\end{array}$ & $\begin{array}{l}-0.038 \\
(0.725)\end{array}$ & $\begin{array}{l}-0.775 \\
(0.670)\end{array}$ & $\begin{array}{l}-0.889 \\
(0.597)\end{array}$ & $\begin{array}{l}-0.965 \\
(0.590)\end{array}$ \\
\hline Elevation & & & $\begin{array}{c}0.254 \\
(0.205)\end{array}$ & $\begin{array}{c}0.318 \\
(0.203)\end{array}$ & $\begin{array}{c}0.134 \\
(0.195)\end{array}$ & $\begin{array}{c}0.235 \\
(0.176)\end{array}$ & $\begin{array}{c}0.237 \\
(0.169)\end{array}$ \\
\hline Average Distance to Nearest Waterway & & & $\begin{array}{c}0.220 \\
(0.189)\end{array}$ & $\begin{array}{c}0.382^{* *} \\
(0.178)\end{array}$ & $\begin{array}{c}0.159 \\
(0.149)\end{array}$ & $\begin{array}{l}-0.011 \\
(0.157)\end{array}$ & $\begin{array}{c}-0.034 \\
(0.160)\end{array}$ \\
\hline Percentage of Arable Land & & & $\begin{array}{c}0.001 \\
(0.005)\end{array}$ & $\begin{array}{c}0.002 \\
(0.005)\end{array}$ & $\begin{array}{c}-0.000 \\
(0.005)\end{array}$ & $\begin{array}{l}-0.003 \\
(0.005)\end{array}$ & $\begin{array}{l}-0.004 \\
(0.005)\end{array}$ \\
\hline Temperature & & & & $\begin{array}{c}0.038^{* * *} \\
(0.011)\end{array}$ & $\begin{array}{c}0.012 \\
(0.017)\end{array}$ & $\begin{array}{c}0.022 \\
(0.017)\end{array}$ & $\begin{array}{c}0.027 \\
(0.018)\end{array}$ \\
\hline Colony & & & & & & & $\begin{array}{c}-0.251 \\
(0.246)\end{array}$ \\
\hline Continental FE & No & No & No & No & Yes & Yes & Yes \\
\hline Legal Origin FE & No & No & No & No & No & Yes & Yes \\
\hline $\mathrm{N}$ & 144 & 144 & 144 & 144 & 144 & 144 & 144 \\
\hline Adjusted $R^{2}$ & 0.113 & 0.125 & 0.201 & 0.261 & 0.446 & 0.506 & 0.506 \\
\hline
\end{tabular}

This table presents the results of a series of 2SLS regression analyses, on the contemporary country level, of a measure of contemporary autocracy on predicted genetic diversity, instrumented by the migratory distance from East Africa to the country, conditional on a range of control variables. Specifications marked with "Continental FE" accounts for sub-Saharan Africa, Latin America, and continental fixed effects. Heteroscedasticity-consistent standard errors are reported in parentheses. *** Significant at the 1 percent level. ${ }^{* *}$ Significant at the 5 percent level. $*$ Significant at the 10 percent level.

This table establishes that the findings in Table 14 are robust to accounting for population density in 1500 . 
Table B.52: Predicted Diversity and Autocracy - Accounting for Social Infrastructure

\begin{tabular}{|c|c|c|c|c|c|c|c|}
\hline & \multicolumn{7}{|c|}{ Log Autocracy } \\
\hline & (1) & $(2)$ & (3) & (4) & (5) & (6) & (7) \\
\hline Predicted Genetic Diversity & $\begin{array}{c}8.062^{* * *} \\
(1.649)\end{array}$ & $\begin{array}{c}8.302^{* * *} \\
(1.639)\end{array}$ & $\begin{array}{c}5.944^{* * *} \\
(1.899)\end{array}$ & $\begin{array}{c}6.579^{* * *} \\
(2.082)\end{array}$ & $\begin{array}{l}4.972^{*} \\
(2.616)\end{array}$ & $\begin{array}{c}6.615^{* * *} \\
(2.481)\end{array}$ & $\begin{array}{r}6.654^{* * *} \\
(2.476)\end{array}$ \\
\hline Social Infrastructure & $\begin{array}{c}-1.085^{* * *} \\
(0.191)\end{array}$ & $\begin{array}{c}-0.918^{* * *} \\
(0.251)\end{array}$ & $\begin{array}{c}-0.902^{* * *} \\
(0.230)\end{array}$ & $\begin{array}{c}-0.440 \\
(0.365)\end{array}$ & $\begin{array}{l}-0.568 \\
(0.401)\end{array}$ & $\begin{array}{c}-0.077 \\
(0.479)\end{array}$ & $\begin{array}{l}-0.113 \\
(0.498)\end{array}$ \\
\hline Log Absolute Latitude & & $\begin{array}{l}-0.087 \\
(0.059)\end{array}$ & $\begin{array}{c}-0.026 \\
(0.060)\end{array}$ & $\begin{array}{c}0.058 \\
(0.076)\end{array}$ & $\begin{array}{l}-0.074 \\
(0.073)\end{array}$ & $\begin{array}{c}-0.069 \\
(0.071)\end{array}$ & $\begin{array}{l}-0.073 \\
(0.071)\end{array}$ \\
\hline Soil Fertility & & & $\begin{array}{c}-1.134^{* *} \\
(0.497)\end{array}$ & $\begin{array}{c}-1.041^{* *} \\
(0.472)\end{array}$ & $\begin{array}{l}-0.349 \\
(0.328)\end{array}$ & $\begin{array}{c}-0.356 \\
(0.320)\end{array}$ & $\begin{array}{l}-0.356 \\
(0.323)\end{array}$ \\
\hline Roughness & & & $\begin{array}{l}-0.628 \\
(0.669)\end{array}$ & $\begin{array}{c}-0.622 \\
(0.675)\end{array}$ & $\begin{array}{l}-0.780 \\
(0.577)\end{array}$ & $\begin{array}{c}-0.803 \\
(0.553)\end{array}$ & $\begin{array}{l}-0.836 \\
(0.573)\end{array}$ \\
\hline Elevation & & & $\begin{array}{l}0.461^{*} \\
(0.238)\end{array}$ & $\begin{array}{c}0.566^{* *} \\
(0.265)\end{array}$ & $\begin{array}{l}0.436^{*} \\
(0.224)\end{array}$ & $\begin{array}{c}0.452^{* *} \\
(0.214)\end{array}$ & $\begin{array}{c}0.466^{* *} \\
(0.219)\end{array}$ \\
\hline Average Distance to Nearest Waterway & & & $\begin{array}{c}-0.146 \\
(0.244)\end{array}$ & $\begin{array}{c}-0.085 \\
(0.259)\end{array}$ & $\begin{array}{l}-0.023 \\
(0.277)\end{array}$ & $\begin{array}{c}-0.086 \\
(0.276)\end{array}$ & $\begin{array}{l}-0.102 \\
(0.281)\end{array}$ \\
\hline Percentage of Arable Land & & & $\begin{array}{c}0.002 \\
(0.005)\end{array}$ & $\begin{array}{c}0.003 \\
(0.005)\end{array}$ & $\begin{array}{l}-0.004 \\
(0.006)\end{array}$ & $\begin{array}{c}-0.003 \\
(0.005)\end{array}$ & $\begin{array}{l}-0.003 \\
(0.005)\end{array}$ \\
\hline Temperature & & & & $\begin{array}{l}0.026^{*} \\
(0.014)\end{array}$ & $\begin{array}{c}0.016 \\
(0.012)\end{array}$ & $\begin{array}{c}0.019 \\
(0.014)\end{array}$ & $\begin{array}{c}0.021 \\
(0.016)\end{array}$ \\
\hline Colony & & & & & & & $\begin{array}{l}-0.155 \\
(0.329)\end{array}$ \\
\hline Continental FE & No & No & No & No & Yes & Yes & Yes \\
\hline Legal Origin FE & No & No & No & No & No & Yes & Yes \\
\hline $\mathrm{N}$ & 108 & 108 & 108 & 108 & 108 & 108 & 108 \\
\hline Adjusted $R^{2}$ & 0.254 & 0.257 & 0.314 & 0.331 & 0.468 & 0.491 & 0.487 \\
\hline
\end{tabular}

This table establishes that the findings in Table 14 are robust to accounting for social infrastructure. 
Table B.53: Predicted Diversity and Autocracy — Accounting for Ethnic Fractionalization

\begin{tabular}{|c|c|c|c|c|c|c|c|}
\hline & \multicolumn{7}{|c|}{ Log Autocracy } \\
\hline & $(1)$ & $(2)$ & $(3)$ & $(4)$ & $(5)$ & $(6)$ & $(7)$ \\
\hline Predicted Genetic Diversity & $\begin{array}{c}7.475^{* * *} \\
(1.867)\end{array}$ & $\begin{array}{c}7.828^{* * *} \\
(1.877)\end{array}$ & $\begin{array}{c}6.237^{* * *} \\
(2.020)\end{array}$ & $\begin{array}{c}6.551^{* * *} \\
(1.952)\end{array}$ & $\begin{array}{l}7.046^{* *} \\
(3.036)\end{array}$ & $\begin{array}{c}7.329^{* * *} \\
(2.731)\end{array}$ & $\begin{array}{c}7.434^{* * *} \\
(2.737)\end{array}$ \\
\hline Ethnic Fractionalization & $\begin{array}{c}0.627^{* *} \\
(0.249)\end{array}$ & $\begin{array}{c}0.467 \\
(0.302)\end{array}$ & $\begin{array}{c}-0.047 \\
(0.340)\end{array}$ & $\begin{array}{c}-0.311 \\
(0.311)\end{array}$ & $\begin{array}{c}-0.036 \\
(0.294)\end{array}$ & $\begin{array}{c}-0.239 \\
(0.319)\end{array}$ & $\begin{array}{c}-0.251 \\
(0.316)\end{array}$ \\
\hline Log Absolute Latitude & & $\begin{array}{l}-0.083 \\
(0.065)\end{array}$ & $\begin{array}{l}-0.066 \\
(0.059)\end{array}$ & $\begin{array}{c}0.138^{*} \\
(0.081)\end{array}$ & $\begin{array}{l}-0.050 \\
(0.082)\end{array}$ & $\begin{array}{l}-0.047 \\
(0.072)\end{array}$ & $\begin{array}{l}-0.055 \\
(0.072)\end{array}$ \\
\hline Soil Fertility & & & $\begin{array}{c}-1.293^{* * *} \\
(0.494)\end{array}$ & $\begin{array}{c}-1.163^{* *} \\
(0.464)\end{array}$ & $\begin{array}{l}-0.450 \\
(0.385)\end{array}$ & $\begin{array}{c}-0.852^{* *} \\
(0.370)\end{array}$ & $\begin{array}{r}-0.847^{* *} \\
(0.371)\end{array}$ \\
\hline Roughness & & & $\begin{array}{l}-0.266 \\
(0.766)\end{array}$ & $\begin{array}{l}-0.193 \\
(0.775)\end{array}$ & $\begin{array}{l}-0.872 \\
(0.691)\end{array}$ & $\begin{array}{l}-0.979 \\
(0.610)\end{array}$ & $\begin{array}{l}-1.069^{*} \\
(0.597)\end{array}$ \\
\hline Elevation & & & $\begin{array}{c}0.313 \\
(0.211)\end{array}$ & $\begin{array}{c}0.426^{* *} \\
(0.214)\end{array}$ & $\begin{array}{c}0.207 \\
(0.206)\end{array}$ & $\begin{array}{c}0.356^{*} \\
(0.188)\end{array}$ & $\begin{array}{l}0.351^{*} \\
(0.181)\end{array}$ \\
\hline Average Distance to Nearest Waterway & & & $\begin{array}{c}0.204 \\
(0.186)\end{array}$ & $\begin{array}{c}0.374^{* *} \\
(0.179)\end{array}$ & $\begin{array}{c}0.152 \\
(0.148)\end{array}$ & $\begin{array}{c}-0.051 \\
(0.162)\end{array}$ & $\begin{array}{c}-0.072 \\
(0.164)\end{array}$ \\
\hline Percentage of Arable Land & & & $\begin{array}{l}-0.001 \\
(0.005)\end{array}$ & $\begin{array}{c}0.001 \\
(0.005)\end{array}$ & $\begin{array}{l}-0.003 \\
(0.005)\end{array}$ & $\begin{array}{l}-0.004 \\
(0.005)\end{array}$ & $\begin{array}{l}-0.004 \\
(0.005)\end{array}$ \\
\hline Temperature & & & & $\begin{array}{c}0.041^{* * *} \\
(0.011)\end{array}$ & $\begin{array}{c}0.014 \\
(0.017)\end{array}$ & $\begin{array}{c}0.025 \\
(0.017)\end{array}$ & $\begin{array}{l}0.031^{*} \\
(0.017)\end{array}$ \\
\hline Colony & & & & & & & $\begin{array}{l}-0.292 \\
(0.238)\end{array}$ \\
\hline Continental FE & No & No & No & No & Yes & Yes & Yes \\
\hline Legal Origin FE & No & No & No & No & No & Yes & Yes \\
\hline $\mathrm{N}$ & 144 & 144 & 144 & 144 & 144 & 144 & 144 \\
\hline Adjusted $R^{2}$ & 0.102 & 0.102 & 0.200 & 0.267 & 0.436 & 0.508 & 0.510 \\
\hline
\end{tabular}

This table presents the results of a series of 2SLS regression analyses, on the contemporary country level, of a measure of contemporary autocracy on predicted genetic diversity, instrumented by the migratory distance from East Africa to the country, conditional on a range of control variables. Specifications marked with "Continental FE" accounts for sub-Saharan Africa, Latin America, and continental fixed effects. Heteroscedasticity-consistent standard errors are reported in parentheses. *** Significant at the 1 percent level. ${ }^{* *}$ Significant at the 5 percent level. $*$ Significant at the 10 percent level.

This table establishes that the findings in Table 14 are robust to accounting for ethnic fractionalization. 
Table B.54: Predicted Genetic Diversity and Democracy (1994-2013)

\begin{tabular}{|c|c|c|c|c|c|c|c|}
\hline & \multicolumn{7}{|c|}{ Log Democracy } \\
\hline & (1) & $(2)$ & $(3)$ & $(4)$ & $(5)$ & $(6)$ & (7) \\
\hline Predicted Genetic Diversity & $\begin{array}{c}-8.566^{* * *} \\
(1.946)\end{array}$ & $\begin{array}{c}-8.658^{* * *} \\
(1.955)\end{array}$ & $\begin{array}{c}-6.003^{* * *} \\
(2.175)\end{array}$ & $\begin{array}{c}-5.980^{* * *} \\
(2.116)\end{array}$ & $\begin{array}{l}-6.553^{*} \\
(3.333)\end{array}$ & $\begin{array}{c}-6.866^{* *} \\
(2.894)\end{array}$ & $\begin{array}{c}-6.863^{* *} \\
(3.099)\end{array}$ \\
\hline Log Absolute Latitude & & $\begin{array}{c}0.196^{* * *} \\
(0.062)\end{array}$ & $\begin{array}{c}0.112^{*} \\
(0.066)\end{array}$ & $\begin{array}{l}-0.137 \\
(0.098)\end{array}$ & $\begin{array}{c}0.059 \\
(0.108)\end{array}$ & $\begin{array}{c}0.043 \\
(0.100)\end{array}$ & $\begin{array}{c}0.048 \\
(0.104)\end{array}$ \\
\hline Soil Fertility & & & $\begin{array}{l}1.132^{* *} \\
(0.504)\end{array}$ & $\begin{array}{l}0.946^{*} \\
(0.482)\end{array}$ & $\begin{array}{c}0.309 \\
(0.446)\end{array}$ & $\begin{array}{c}0.704^{*} \\
(0.425)\end{array}$ & $\begin{array}{c}0.593 \\
(0.507)\end{array}$ \\
\hline Roughness & & & $\begin{array}{c}0.337 \\
(0.715)\end{array}$ & $\begin{array}{c}0.123 \\
(0.737)\end{array}$ & $\begin{array}{c}0.819 \\
(0.733)\end{array}$ & $\begin{array}{c}0.843 \\
(0.641)\end{array}$ & $\begin{array}{c}0.550 \\
(0.639)\end{array}$ \\
\hline Elevation & & & $\begin{array}{l}-0.243 \\
(0.202)\end{array}$ & $\begin{array}{l}-0.327 \\
(0.205)\end{array}$ & $\begin{array}{l}-0.138 \\
(0.213)\end{array}$ & $\begin{array}{l}-0.284 \\
(0.192)\end{array}$ & $\begin{array}{l}-0.269 \\
(0.183)\end{array}$ \\
\hline Average Distance to Nearest Waterway & & & $\begin{array}{l}-0.263 \\
(0.191)\end{array}$ & $\begin{array}{c}-0.435^{* *} \\
(0.181)\end{array}$ & $\begin{array}{l}-0.248 \\
(0.160)\end{array}$ & $\begin{array}{l}-0.012 \\
(0.175)\end{array}$ & $\begin{array}{l}-0.058 \\
(0.169)\end{array}$ \\
\hline Percentage of Arable Land & & & $\begin{array}{c}0.002 \\
(0.005)\end{array}$ & $\begin{array}{l}-0.000 \\
(0.005)\end{array}$ & $\begin{array}{c}0.003 \\
(0.006)\end{array}$ & $\begin{array}{c}0.003 \\
(0.005)\end{array}$ & $\begin{array}{c}0.006 \\
(0.006)\end{array}$ \\
\hline Temperature & & & & $\begin{array}{c}-0.044^{* * *} \\
(0.012)\end{array}$ & $\begin{array}{l}-0.017 \\
(0.018)\end{array}$ & $\begin{array}{l}-0.029 \\
(0.019)\end{array}$ & $\begin{array}{c}-0.038^{* *} \\
(0.017)\end{array}$ \\
\hline Colony & & & & & & & $\begin{array}{c}0.365 \\
(0.229)\end{array}$ \\
\hline Continental FE & No & No & No & No & Yes & Yes & Yes \\
\hline Legal Origin FE & No & No & No & No & No & Yes & Yes \\
\hline$N$ & 145 & 145 & 145 & 145 & 145 & 145 & 130 \\
\hline Adjusted $R^{2}$ & 0.063 & 0.100 & 0.195 & 0.267 & 0.397 & 0.484 & 0.511 \\
\hline
\end{tabular}

This table presents the results of a series of OLS regression analyses, on the contemporary country level, of a measure of contemporary democracy on predicted genetic diversity, conditional on a range of control variables. Specifications marked with "Continental FE" accounts for sub-Saharan Africa, Latin America, and continental fixed effects. Heteroscedasticity-consistent standard errors are reported in parentheses. ${ }^{* * *}$ Significant at the 1 percent level. ${ }^{* *}$ Significant at the 5 percent level. $*$ Significant at the 10 percent level. 


\section{Definitions of main variables}

This section describes the construction of the main variables.

\section{Number of Levels of Jurisdictional Hierarchy}

This variable is based on variable 33 in the Ethnographic Atlas, denoted "Jurisdictional Hierarchy Beyond Local Community". The Number of Levels of Jurisdictional Hierarchy variable takes on the value 1 when the original variable indicates "No levels (no political authority beyond community)", 2 when it indicates "One levels (e.g., petty chiefdoms)", 3 when it indicates "Two levels (e.g., larger chiefdoms)", 4 when it indicates "Three levels (e.g., states)", 5 when it indicates "Four levels (e.g., large states)".

\section{Genetic Diversity}

The data on observed genetic diversity on the ethnic group level comes from the newly assembled data on observed genetic diversity in 232 worldwide (predominantly indigenous) ethnic groups from Pemberton et al. (2013). The data on predicted genetic diversity on the modern country level comes from (Ashraf and Galor, 2013).

\section{Social Stratification}

This variable is based on variable 66 in the Ethnographic Atlas, denoted "Class Stratification". The Social Stratification variable takes on the value 0 when the original variable indicates "Absence among freemen)", 1 when it indicates "Wealth distinctions" or "Elite (based on control of land or other resources", and 2 when it indicates "Dual (hereditary aristocracy)" or "Complex (social classes)".

\section{Intensity of Slavery}

This variable is based on variable 66 in the Ethnographic Atlas, denoted "Type of Slavery". The Intensity of Slavery variable takes on the value 0 when the original variable indicates "Absence or near absence", 1 when it indicates "Incipient or nonhereditary" or "Reported but type not identified", and 2 when it indicates "Hereditary and socially significant".

\section{Indigenous Autocracy}

This variable is based on variable 72 in the Ethnographic Atlas, denoted "Succession to the Office of Local Headman". The Indigenous Autocracy variable takes on the value 1 when the original variable indicates "Election or other formal consensus, nonhereditary", 2 when it indicates "Informal consensus, nonhereditary", and 3 when it indicates "Patrilineal heir", "Matrilineal heir", "Appointment by higher authority, nonhereditary", "Seniority or age, nonhereditary", "Influence, wealth or social status, nonhereditary", or "Absence of any such office". 


\section{Executive Constraints}

This variable come from the Polity IV Project dataset (Marshall et al., 2014). The variable takes on an integer values from 1 to 7 , indicating increasing extends of "institutionalized constraints on the decision-making powers of chief executives, whether individuals or collectivities" (Marshall et al., 2014).

\section{Autocracy}

This variable come from the Polity IV Project dataset (Marshall et al., 2014). The variable takes on the value 0 or an integer value from 1 to 10, indicating increasing extends of "the presence of a distinctive set of political characteristics" characterizing autocracy. According to the definition, in their mature form, "autocracies sharply restrict or suppress competitive political participation" (Marshall et al., 2014).

\section{Migratory Distance from East Africa}

In estimating the migratory distance from Addis Ababa (East Africa) for each of the ethnic groups in the data, the shortest traversable paths from Addis Ababa to the interior centroid of each ethnic group was computed. Given the limited ability of humans to travel across large bodies of water, the traversable area included bodies of water at a distance of $100 \mathrm{~km}$ from land mass (excluding migration from Africa into Europe via Italy or Spain). Furthermore, for ethnicities that reside in a distance that exceed $100 \mathrm{~km}$ from the traversable area connected to Addis Ababa, the distance was computed in the following way. A point set was created by clipping the extended traversable area to world boundaries and aggregating it to a resolution of 2,096,707 pixels which was then converted into points. For each ethnicity centroid, the nearest four distance points were identified and the great circle distance from the ethnicity centroid to those points were calculated. These distances was then added to the migratory distance from Addis Ababa at the distance point to obtain the total migratory distance from the ethnicity centroid from Addis Ababa to each of these

four points. The point with the shortest total migratory distance from Addis Ababa was selected to represent the total migratory distance for the ethnicity.

\section{Control Variables}

The control variables come from a range of sources. For the analysis of the pre-colonial era, the developed geo-referenced dataset on within-ethnic-group genetic diversity and ethnographic information contains a wide range of variables (see Ashraf et al., 2015, for more information on the data). Since the data is partly based on Fenske (2013), it includes a range of geographic variables derived by him, in addition to geographic variables derived by the authors. These geographic variables include elevation, ruggedness, length and density of rivers in the area, share of desert on the area, as well as the average climatic suitability for agriculture (as constructed by Ramankutty et al. (2002) and also used by Michalopoulos (2012)), average temperature, and average diurnal temperature range over the period 19012012 as constructed by the Climate Research Unit (see Harris et al., 2014). 